\title{
Methylmercury in Managed Wetlands
}

by

\section{Rachel Jean Strickman}

\section{A thesis submitted in conformity with the requirements for the degree of Doctor of Philosophy \\ Department of Physical and Environmental Science University of Toronto}




\begin{abstract}
Methylmercury (MeHg), a bioaccumulative neurotoxin, is microbially produced in anoxic wetland environments. The direct or indirect management of wetlands is pervasive, but many questions remain regarding the impact of wetland management on $\mathrm{MeHg}$ biogeochemistry. To address this, I investigated the extent, drivers, and consequences of $\mathrm{MeHg}$ production in important types of managed wetlands, as well as the response of $\mathrm{MeHg}$ to specific management interventions. In a field study which simulated industrial increases and legislated decreases in sulfate deposition to peatlands, I found evidence that $\mathrm{MeHg}$ production in peatlands is quantitatively related to sulfate-mediated changes in the community structure of the Deltaproteobacteria, rather than simple metabolic stimulation of sulfate-reducing bacteria (SRB), one in the best studied groups of mercury methylators. Furthermore, the structure of the bacterial community, as well as MeHg accumulation, was resilient to the end of sulfate amendments, demonstrating the value of this management intervention.
\end{abstract}

In a series of observational biogeochemical field studies in artificial wetlands, I found similar evidence that the wetland microflora was resilient to the disturbance of wetland dredging, which only temporarily reduced $\mathrm{MeHg}$ production and concentrations. Methylmercury production in stormwater wetlands was carried out by SRB, with their activity modulated by availability of inorganic mercury, labile and total organic carbon, and competition with nitrate reducers. $\mathrm{MeHg}$ production in stormwater wetlands was overall dampened in comparison to those managed for habitat provision.

Finally, I used a controlled greenhouse experiment to study the source of $\mathrm{MeHg}$ and $\mathrm{IHg}$ to paddy grown rice, a staple food recently shown to be a significant dietary source of $\mathrm{MeHg}$ to some populations. I confirmed the soil origin of $\mathrm{MeHg}$ to rice grains, and identified a window of elevated $\mathrm{MeHg}$ uptake during vegetated growth. Inorganic mercury, by contrast, appears to derive from the atmosphere alone, presenting challenges in controlling its concentrations in rice. 


\section{Acknowledgments}

Firstly, I would like to thank my advisors, Carl Mitchell, Roberta Fulthorpe, and Marney Isaac, for their support, guidance, and understanding as I navigated through not only a Ph.D., but a new country, marriage and parenthood. I will always be particularly grateful for your enthusiastic support for my pursuit of my own research ideas, which was a true privilege.

In addition, I would like to thank Shelley Eisner, Elaine Pick, and Jennifer Caradonna of the DPES administrative support team for their quick and helpful responses to all my administrative questions. Eventually I even reached the point of filling out expense claims without mistakes, at least once or twice! I would also like to extend a particular thank you to Planck (Haiyong) Huang for his endless patience and good nature as he demonstrated laboratory techniques, bringing a smile to even the most frustrating day with the ICP-MS.

Research can be lonely, but I was so fortunate to have wonderful $\mathrm{PhD}$ colleagues with whom to share frustrations, ideas, and XKCD cartoons. In particular, Ingjerd Sunde Krogseth, Johnny Westgate, Nicole Ricker, Rosemary Saati, and Carlos Paulo made the ninety minute commute worth it. A big thank you also to my "science pals" near and far, especially Annett Schumacher and Zoe Goodwin for their ongoing moral support! Finally, a special thank you to my close friends Diana Cousminer and Genevieve Noyce, and their families Rachel Kahan-Noyce, Ami Ganguli, Elliott Lehtonen, and Misha Ganguli, for their company and support as we wrote up PhDs from each other's kitchen tables - a special kind of enjoyment, to work from home with people who understand what the work is about!

Thank you to my parents, Dan and Linda Strickman, my sisters Leah and Rose, and my brother in law Laurence Scott — for five years of reality checks, commiseration, and advice both critical and partisan. I'd also like to thank my family by marriage, the Lombardi-Spanos, for so many great family meals and parties to take my mind off methylmercury and R!

My love and gratitude go to my husband, Luciano Lombardi, who was always there for me when I needed him, in so many ways. And finally, in subject and in spirit, this thesis turned out to be for my son, Daniel, who has made it all worthwhile. 


\section{Table of Contents}

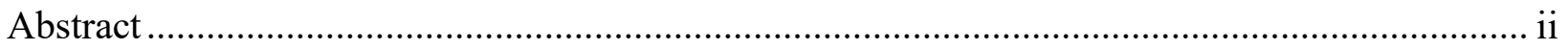

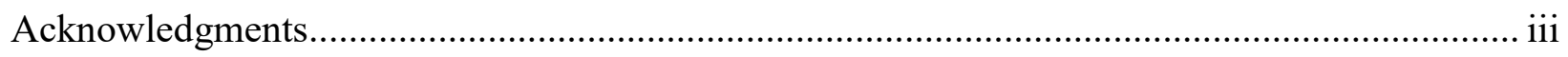

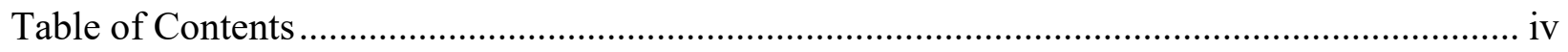

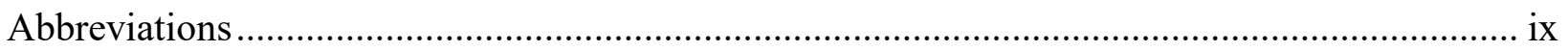

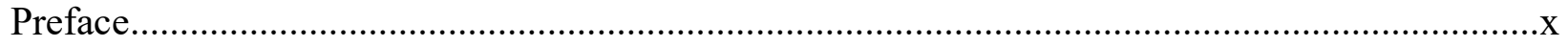

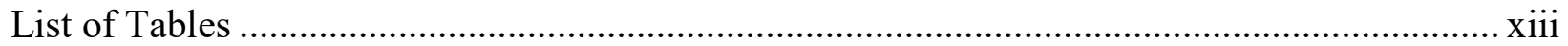

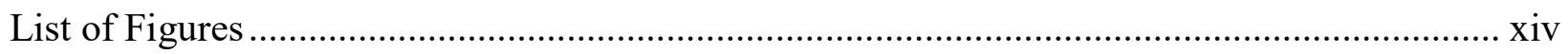

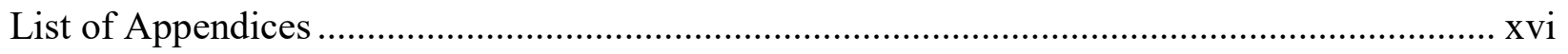

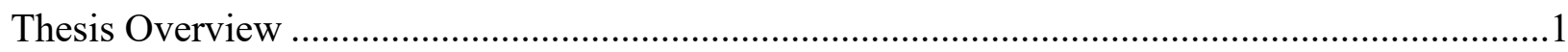

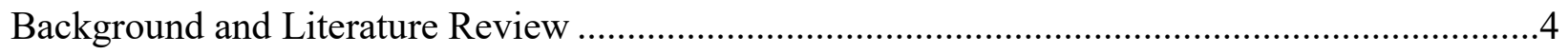

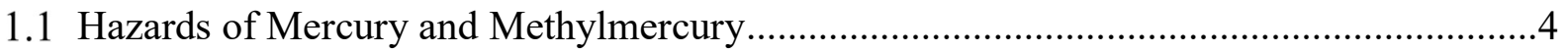

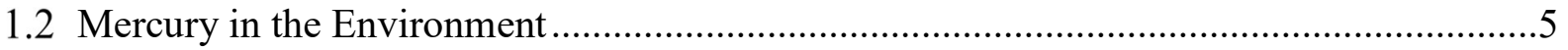

1.2.1 Sources, transformations, and fates of mercury in the global environment............5

1.2.2 Sources, transport and fate of mercury in the aquatic environment ....................6

1.3 The Wetland Environment .................................................................................

1.3.1 Wetland hydrology and biogeochemistry ...............................................

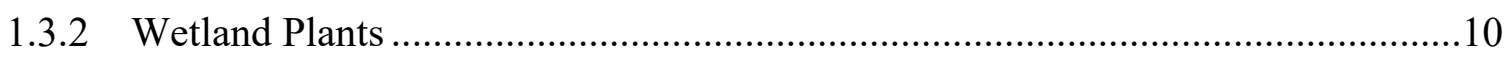

1.4 The Methylmercury Cycle ................................................................................. 11

1.4.1 Physical location of mercury methylation in the aquatic environment.................11

1.4.2 The taxonomic distribution of mercury methylation capacity .............................11

1.4.3 Mercury bioavailability and uptake by mercury methylators ...........................13

1.4.4 Mercury methylation rates and measurement techniques .................................14 


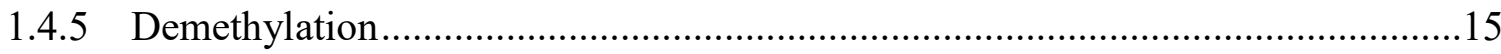

1.4.6 Methylmercury bioaccumulation ....................................................................15

1.4.7 Environmental factors correlating with mercury methylation ...............................17

1.4.8 Relationship of wetland plants to MeHg biogeochemistry.....................................18

1.4.9 Variation in mercury methylation between and within freshwater wetlands ........19

1.4.10 Small artificial wetlands as sources of methylmercury ......................................20

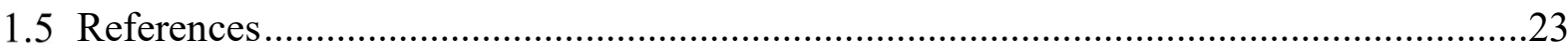

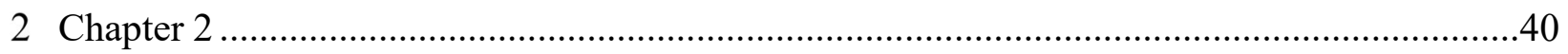

Methylmercury production and accumulation in urban stormwater and habitat wetlands ............40

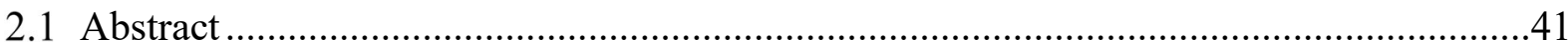

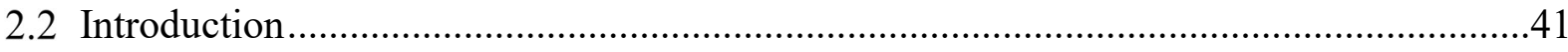

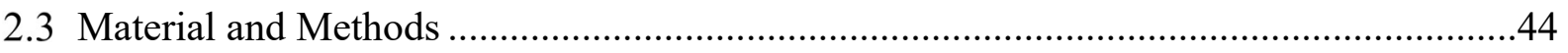

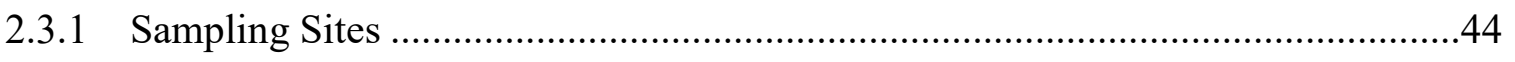

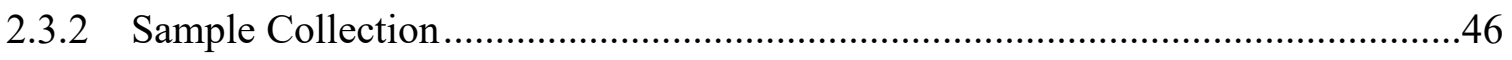

2.3.3 Mercury Methylation Assays .............................................................................46

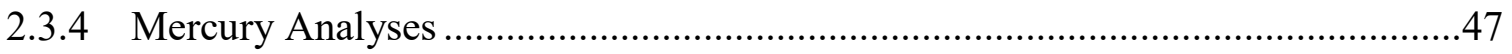

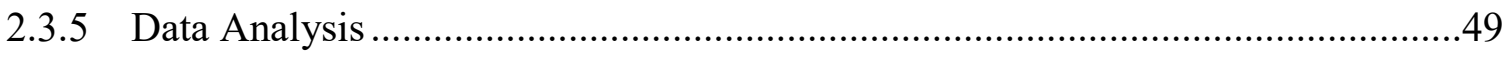

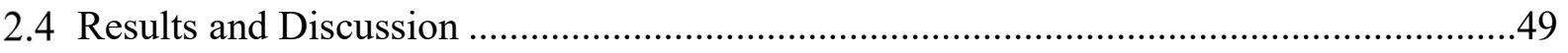

2.4.1 Mercury Methylation in Stormwater and Habitat Wetlands.................................49

2.4.2 Relationship of Wetland Age to Hg Biogeochemistry ..........................................52

2.4.3 Variation in Hg Biogeochemistry across Ecological Zones ...................................54

2.4.4 Relationship of Vegetation to MeHg Biogeochemistry.........................................56

2.4.5 Landscape-scale Implications ……………………............................................57

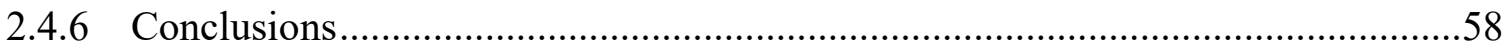

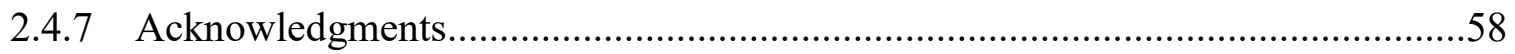




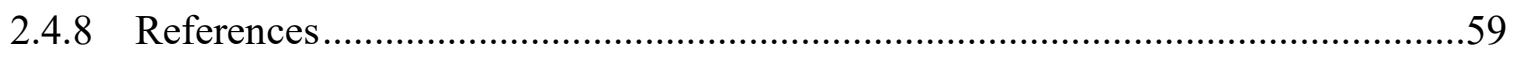

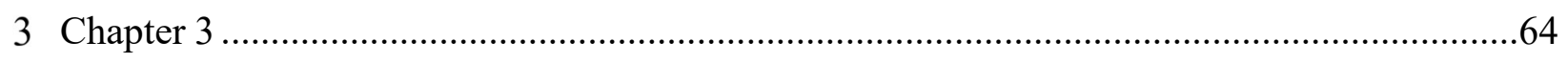

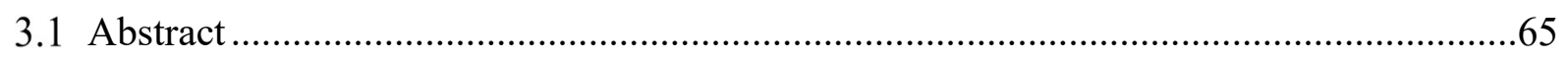

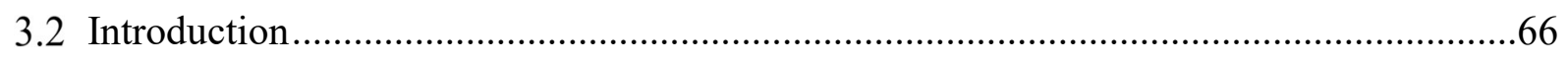

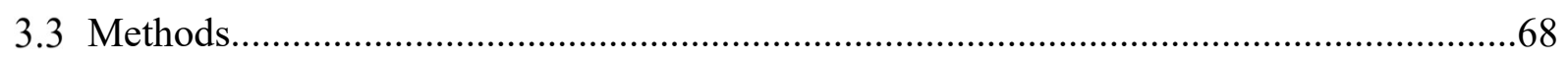

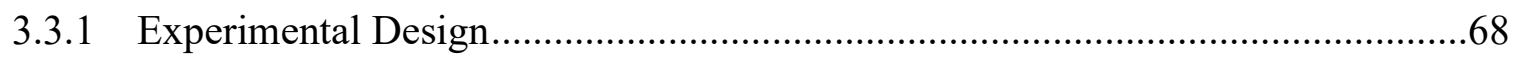

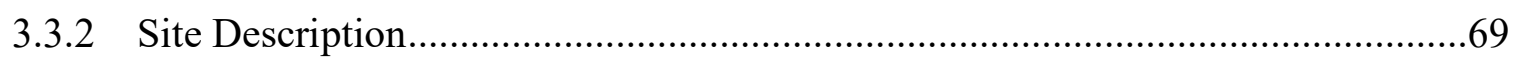

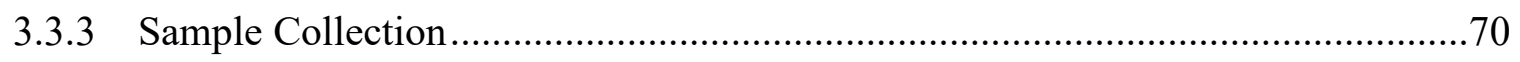

3.3.4 Sediment Laboratory Analyses ........................................................................

3.3.5 Porewater Laboratory Analyses ........................................................................

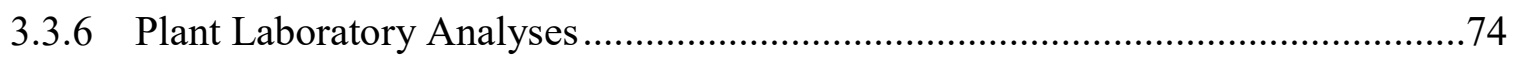

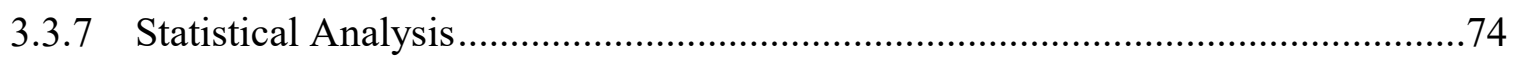

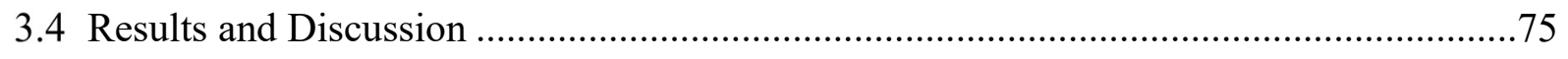

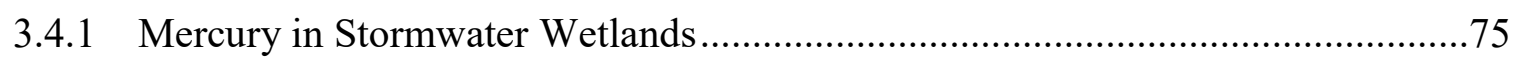

3.4.2 Spatial Variability in Hg Biogeochemistry within Stormwater Wetlands..............80

3.4.3 Biogeochemical Controls on Hg in Stormwater Ponds ........................................82

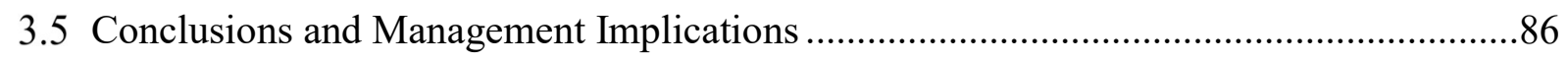

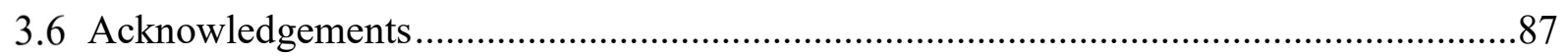

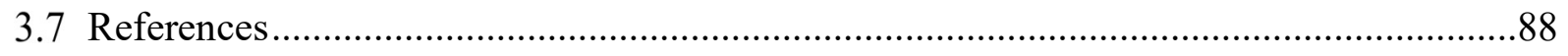

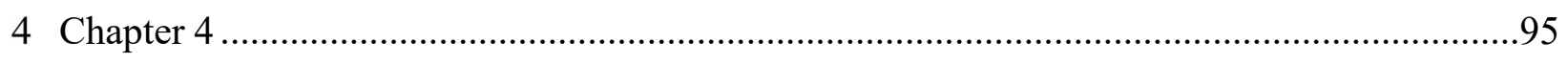

Experimental sulfate amendment alters peatland bacterial community structure .........................95

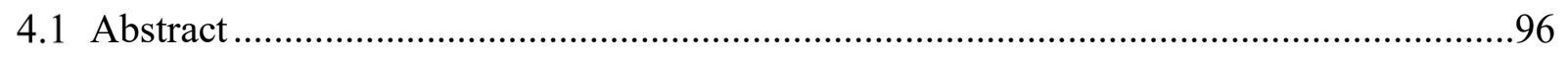

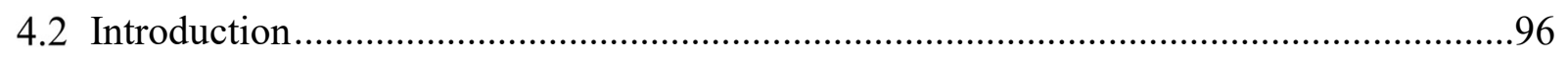

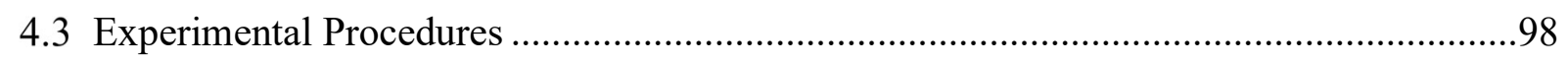

4.3.1 Site Description and Experimental Design ............................................................98 


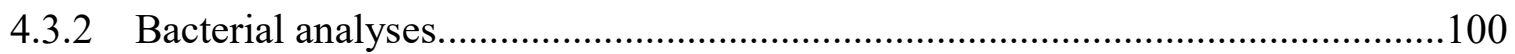

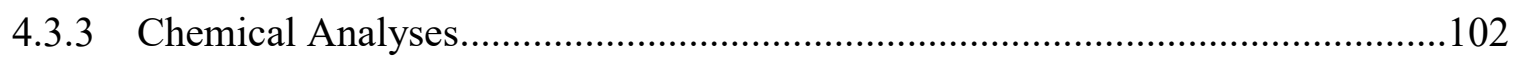

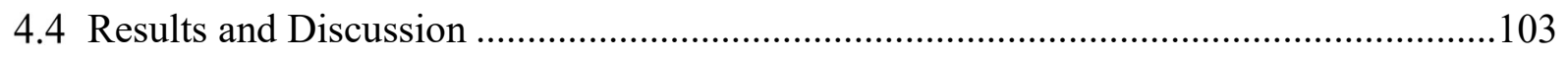

4.4.1 Sulfate Deposition Manipulation Effects ..............................................................103

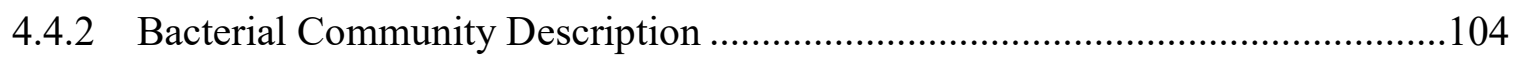

4.4.3 Bacterial Community Responses to Sulfate Amendment......................................107

4.4.4 Relationship Between Sulfate-Mediated Changes in Bacterial Community

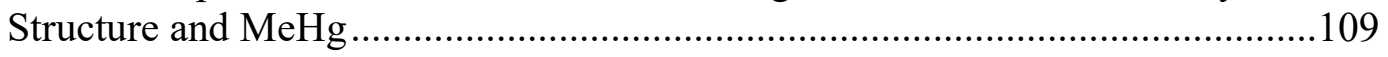

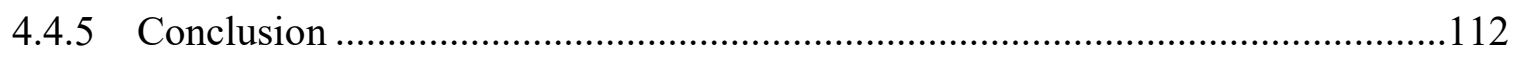

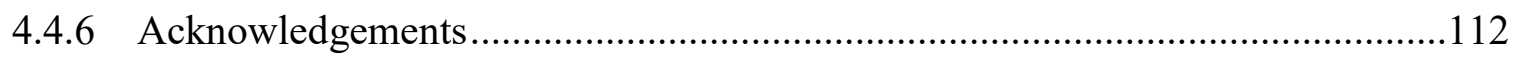

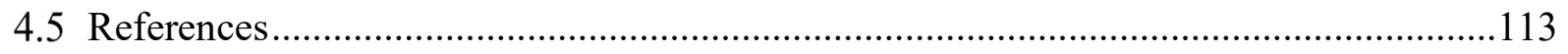

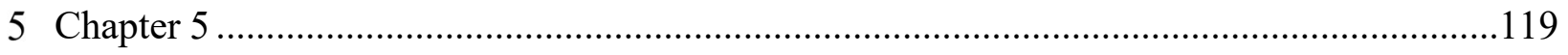

Accumulation and translocation of methylmercury and inorganic mercury in Oryza sativa: an

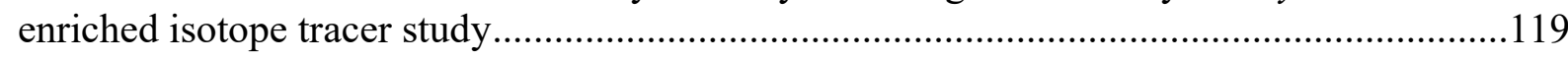

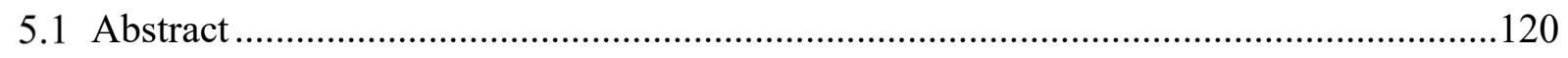

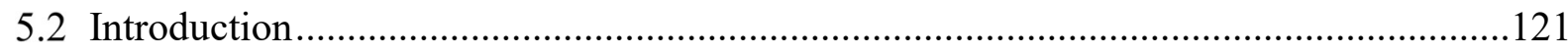

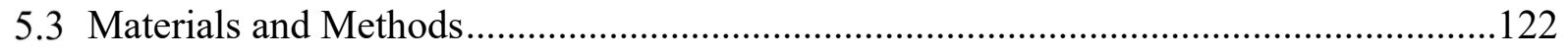

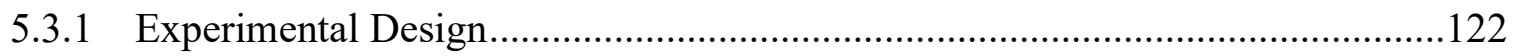

5.3.2 Sediment Dosing, Plant Cultivation and Sample Collection .................................122

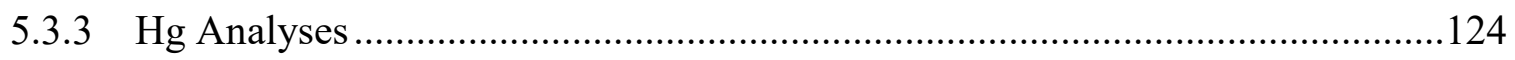

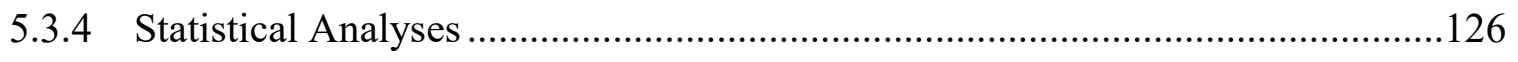

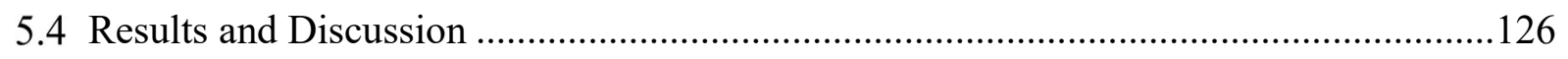

5.4.1 Inorganic Mercury Tracer Amendment …………........................................126

5.4.2 Mercury Methylation in Vegetated and Unvegetated Soils .................................127

5.4.3 Uptake, Translocation, and Bioaccumulation of MeHg and IHg in Plant Tissues. 
5.4.4 Management Implications......

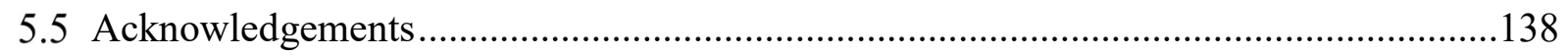

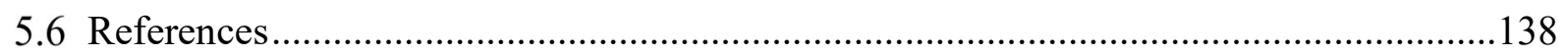

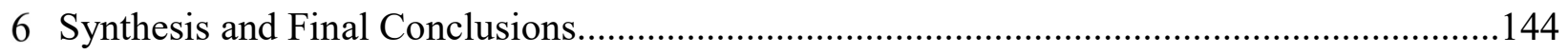

6.1 Relation of $\mathrm{MeHg}$ to specific management interventions......................................... 144

6.2 Drivers of MeHg production in small artificial wetlands stormwater wetlands .............146

6.3 Impact of wetland plants on $\mathrm{MeHg}$ biogeochemistry ............................................. 148

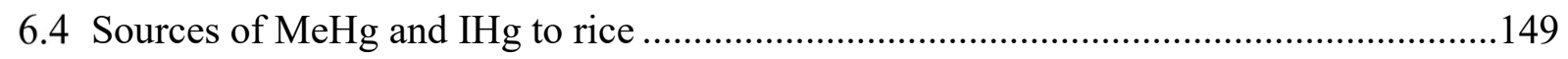

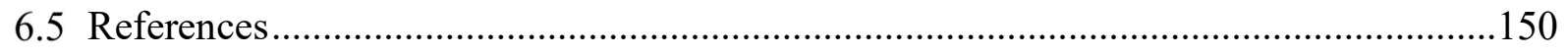




\section{Abbreviations}

$\mathrm{MeHg} \quad$ methylmercury

THg total mercury

$\mathrm{IHg} \quad$ inorganic mercury

$\mathrm{Hg} \quad$ mercury

ICP-MS inductively coupled plasma mass spectrometer 


\section{Preface}

Although I am the primary author of this thesis, others have made important contributions, which I outline below. Chapters 2, 4, and 5 are either published, or in review for publication, and necessarily contain some repetition of methods and background information.

\section{CHAPTER 1}

\section{Introduction and Thesis Overview}

Contributions: Written by Rachel J. Strickman with critical review by Carl P. J. Mitchell.

\section{CHAPTER 2}

\section{Methylmercury production and accumulation in urban stormwater and habitat wetlands}

Contributions: Experimental design was the work of Rachel Strickman and Carl P.J. Mitchell. Field and laboratory data collection was carried out by Rachel Strickman, with significant assistance from Haiyong (Planck) Huang and additional assistance from Suman Dhal and Talent Huang. David Kenth, an engineer at the City of Brampton, provided important background on wetland construction and management practices in that municipality, as well as information on individual wetlands. Data analysis was performed by Rachel Strickman with advice from Adam Martin. Rachel Strickman wrote the manuscript, with the constructive criticism of Carl P.J. Mitchell. This chapter has recently been submitted for publication in Environmental Pollution and is currently in review.

\section{CHAPTER 3}

\section{Mercury methylation in stormwater wetlands at different stages in the management lifecycle}

Contributions: Experimental design was the work of Rachel Strickman and Carl P.J. Mitchell. Field and laboratory data collection was carried out by Rachel Strickman, with significant assistance from Scott Patrick and Haiyong (Planck) Huang. David Kenth, an engineer at the City of Brampton, assisted in the identification of recently dredged wetland sites. Data analysis was 
performed by Rachel Strickman with advice from Adam Martin. Rachel Strickman wrote the manuscript, with the constructive criticism of Carl P.J. Mitchell. This chapter is currently being prepared for submission to a peer-reviewed journal.

\section{CHAPTER 4}

\section{Experimental sulfate amendment alters peatland bacterial community structure.}

This chapter is reproduced as published in Science of the Total Environment (Strickman, R.J., Fulthorpe, R.R., Coleman Wasik, J.K., Engstrom, D.R., Mitchell, C.P.J., 2016. Experimental sulfate amendment alters peatland bacterial community structure. Sci. Total Environ. http://dx.doi:10.1016/j.scitotenv.2016.05.189). The original field experiment was designed, implemented, and maintained by Jeff Jeremiason, Dan Engstrom, Jill Coleman Wasik, Ed Swain, Bruce Monson, Brian Branfireun and Randy Kolka. Additional thanks go to Deacon Kyllander, and Carrie Dorrance of the Northern Research Station for administrative and field assistance throughout the course of the project, and to Haiyong (Planck) Huang, who carried out chemical analyses at the University of Toronto. Rachel Strickman conducted laboratory DNA amplification, and in silico sequence processing and metataxonomic analysis, with invaluable advice from ShuYi (Roxanna) Shen and the Qiime community. Rachel Strickman prepared the manuscript, with advice from Carl P.J. Mitchell, Roberta Fulthorpe, Jill Coleman Wasik, and Dan Engstrom, as well as several anonymous reviewers and editor Mae Gustin. In particular, I would like to thank Daniel Jones of the University of Minnesota for very constructive criticism on the publication value of this project.

\section{CHAPTER 5}

\section{Accumulation and translocation of methylmercury and inorganic mercury in Oryza sativa: an enriched isotope tracer study}

Contributions: This chapter is reproduced as published in Science of the Total Environment (Strickman, R.J., Fulthorpe, R.R., Mitchell, C.P.J., 2016.Accumulation and translocation of methylmercury and inorganic mercury in Oryza sativa: an enriched isotope tracer study. Sci. Total Environ. 10.1016/j.scitotenv.2016.08.068). The experiment was designed by Rachel Strickman and Carl P.J. Mitchell. Dr. Jun Jia and Dr. Jack Okamura of the United States 
Department of Agriculture, and Sandra Harrington of Cornell University gave advice on maintaining Nipponbare rice in a northern greenhouse. Trevor Wilkinson provided advice on hydroponic culture of rice, and Aziz Rahman and Sheila Rush facilitated the use of the UTSC greenhouse. Shreya Mistry, Kevin Ng, Brent Perron, Demin Xu, and Sampreeth Rao provided field and laboratory assistance. Greenhouse and laboratory work was carried out by Rachel Strickman, with the exception of total mercury analyses, which were performed by Haiyong (Planck) Huang and Carl P.J Mitchell. The manuscript was prepared by Rachel Strickman, with critical review by Carl P.J. Mitchell and anonymous reviewers. 


\section{List of Tables}

Table 2.1: Descriptive characteristics of study sites....................................................... 45

Table 2.2: Quality control data for $\mathrm{MeHg}$ and $\mathrm{THg}$ determinations.........................48

Table 3.1: Quality control data for $\mathrm{MeHg}$ and $\mathrm{THg}$ determinations........................... 73

Table 3.2: Summary of porewater chemistry and sediment physical parameters from the new,

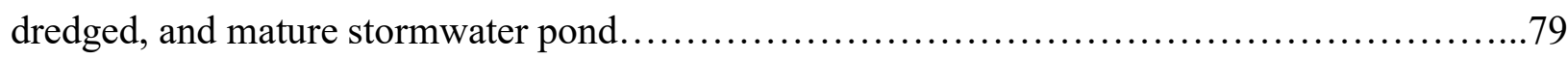

Table 3.3: Summary of sediment chemistry and mercury variables from the new, dredged, and

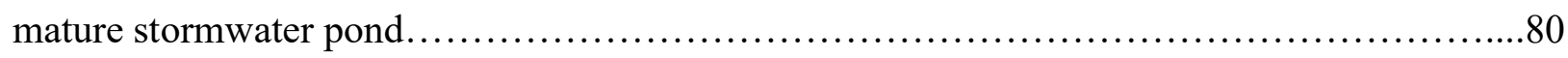

Table 3.4: Summary of plant biomass and carbon exudate from the littoral zone of the mature wetland for Early Summer, Peak Summer, and Fall ................................... 81

Table 5.1: Quality control data for $\mathrm{MeHg}$ and $\mathrm{THg}$ determinations.........................125 


\section{List of Figures}

Figure 2.1: Comparison between stormwater and habitat wetlands of a) sediment total mercury (THg) concentrations, b) sediment methylmercury ( $\mathrm{MeHg}$ ) concentrations, c) percent of sediment mercury present as methylmercury $(\% \mathrm{MeHg}), \mathrm{d})$ potential methylation rate constant $\left(\mathrm{K}_{\text {meth }}\right) \ldots \ldots \ldots \ldots \ldots \ldots \ldots . \ldots . \ldots . \ldots . \ldots$

Figure 2.2: Correlations between methylmercury ( $\mathrm{MeHg}$ ) variables in habitat (left) and stormwater (right) wetlands....

Figure 2.3: Concentrations of sediment inorganic mercury ( $\mathrm{IHg})$, sediment methylmercury (MeHg), the percent of sediment total mercury present as methylmercury $(\% \mathrm{MeHg})$, and potential mercury methylation rate constants $\left(\mathrm{K}_{\mathrm{meth}}\right)$ in sediment from stormwater (left) and habitat (right)

wetlands

Figure 2.4: Concentrations of sediment inorganic mercury ( $\mathrm{IHg})$, sediment methylmercury (MeHg), the percent of sediment total mercury present as methylmercury $(\% \mathrm{MeHg})$, and potential mercury methylation rate constants $\left(\mathrm{K}_{\mathrm{meth}}\right)$ in sediment from stormwater (left) and habitat (right) wetlands, differentiated across ecological zones.

Figure 2.5: Plant biomass (grams dry weight $\mathrm{m}^{-2}$ ) and percent canopy cover in different ecological zones of stormwater (left) and habitat (right) wetlands.

Figure 3.1: Tukey's box plot distribution of $\mathrm{Hg}$ variables in a new, a dredged, and a mature stormwater wetland. Figure displays a) inorganic mercury, b) methylmercury, c) percent of mercury present as methylmercury (Percent $\mathrm{MeHg}, \% \mathrm{MeHg}$ ) and d) potential methylation rate constants $\left(\mathrm{K}_{\mathrm{meth}}\right)$

Figure 3.2: Distribution of mercury variables over early summer, peak summer, and fall in a new, a dredged, and a mature wetland. Figure displays a) inorganic mercury, b) methylmercury, c) percent of mercury present as methylmercury (Percent $\mathrm{MeHg}, \% \mathrm{MeHg}$ ) and d) potential methylation rate constants $\left(\mathrm{K}_{\text {meth }}\right)$......

Figure 3.3: Spatial distribution of a) methylmercury, b) percent of mercury present as methylmercury $(\% \mathrm{MeHg}), \mathrm{c})$ potential methylation rate constants $\left(\mathrm{K}_{\text {meth }}\right)$ and $\left.\mathrm{d}\right)$ porewater sulfate concentrations between the littoral and pelagic zones over the early summer (ES), peak summer (PS), and fall (Fall) of a new, a dredged, and a mature wetland.... .83 
Figure 3.4: Relationships between sediment ammonia concentrations and (a) methylmercury, (b) inorganic mercury, (c) percent of mercury present as methylmercury $(\% \mathrm{MeHg})$ and (d) potential

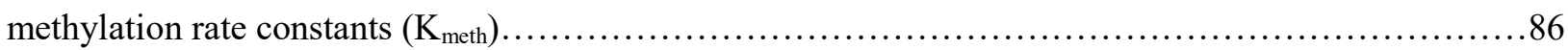

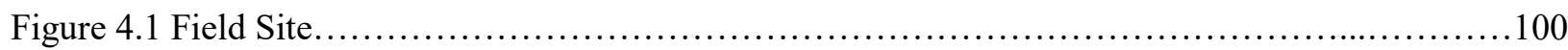

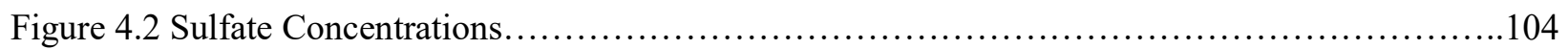

Figure 4.3 Bacterial Communities..................................................... 106

Figure 4.4 Clustering of Bacterial Communities.......................................... 109

Figure 4.5 Methylmercury Accumulation................................................ 112

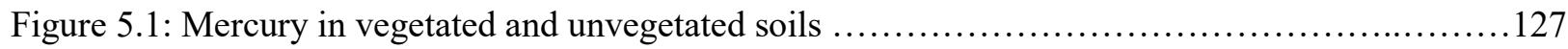

Figure 5.2: Accumulation and distribution of ambient and tracer $\mathrm{MeHg}$ and $\mathrm{IHg}$ in plant tissues at three

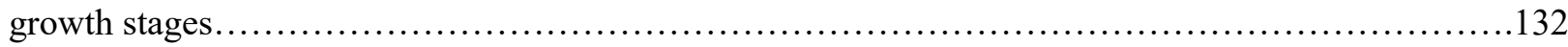

Figure 5.3: Ambient and tracer $\mathrm{MeHg}$ (left) and IHg (right) concentrations in different plant

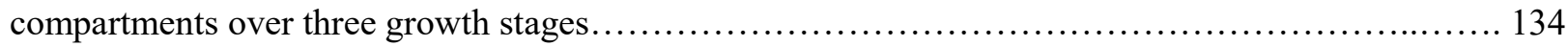




\section{List of Appendices}

7 Appendices .155

7.1 Appendix 1: Additional material for Chapter 4: Experimental sulfate amendment alters peatland bacterial community structure

7.1.1 Supplmementary Table 7.1.1: Quality control data for $\mathrm{MeHg}$ and $\mathrm{THg}$ analyses

7.1.2 Supplmementary Table 7.1.2: Phylum-level Taxonomic Affiliation of Bacterial SSU rRNA amplicon reads (weighted abundance) ............................156

7.1.3 Supplmementary Table 7.1.3: Class-level Taxonomic Affiliation of Bacterial SSU rRNA amplicon reads (weighted abundance).

7.1.4 Supplmementary Table 7.1.4: Order-level Taxonomic Affiliation of Bacterial SSU rRNA amplicon reads (weighted abundance).

7.1.5 Supplmementary Table 7.1.5: Family-level Taxonomic Affiliation of Bacterial SSU rRNA amplicon reads (weighted abundance).

7.1.6 Supplmementary Table 7.1.6: Lagg OTUs with a significant correlation between weighted abundance and the percentage of mercury present as methylmercury $(\% \mathrm{MeHg})$

7.1.7 Supplmementary Table 7.1.7: Bog OTUs with a significant correlation between weighted abundance and the percentage of mercury present as methylmercury $(\% \mathrm{MeHg})$

7.2 Appendix 2: Additional material for Chapter 5: Accumulation and translocation of methylmercury and inorganic mercury in Oryza sativa: an enriched isotope tracer study......

7.2.1 Supplementary Table 7.2.1: Results of statistical tests. 176

7.2.2 Table 7.2.2: Summary statistics for different fractions of ambient and tracer mercury from soils

7.2.3 Supplementary Text 1: Estimation of potential gaseous $\mathrm{Hg}$ flux from experimental pots

7.2.4 Supplementary Text 2: Estimation of mass balance of MeHg in vegetated pots 181

7.2.5 Table 7.2.5: Estimated MeHg burden in vegetated sediments (ng pot ${ }^{-1}$ ) and plants (ng plant ${ }^{-1}$ ) at each growth stage .182

7.2.6 Table 7.2.6: Photosynthetic rate and total plant biomass at each growth stage...182 


\section{Thesis Overview}

The focus of this thesis is the methylmercury $(\mathrm{MeHg})$ biogeochemistry of managed wetlands. Methylmercury is a global health concern, as it is a widespread contaminant of staple foods that causes subtle but damaging neurotoxic effects, even at trace levels (Karagas et al., 2012; Mergler et al., 2007). Methylmercury is produced from inorganic mercury ( $\mathrm{IHg})$, itself a ubiquitous contaminant, by a wide diversity of Bacteria and Archaea in anoxic, aquatic environments like wetlands (Gilmour et al., 2013). The biogeochemistry of MeHg is complex, responding to a wide range of drivers in ways that vary between different environments. Given the prevalence of managed wetlands and of large-scale management interventions, such as control on regional atmospheric emissions of mercury ( $\mathrm{Hg}$ ) (Zhang et al. 2016), the relationship of $\mathrm{MeHg}$ biogeochemistry to wetland management is a topic which impinges on landscape level $\mathrm{MeHg}$ production, human and animal health, and the safety of the global food supply (Chumchal and Drenner, 2015). The goal of my graduate research has been to extend our basic understanding of the extent and drivers of $\mathrm{MeHg}$ production, accumulation and trophic transfer (specifically into plants) in managed wetlands, and the response of $\mathrm{MeHg}$ biogeochemistry to specific management interventions.

A major focus of my research has been to characterize and explain the extent of $\mathrm{MeHg}$ production in small urban artificial wetlands, in particular those managed for stormwater control and habitat provision. These wetlands are an increasingly popular way to offset the destruction of natural wetlands and reduce the flooding and pollution risks associated with stormflow in urban and suburban areas (Scholz and Lee, 2005). However, there is a dearth of information about the degree to which these environments produce and accumulate $\mathrm{MeHg}$ and the drivers of their $\mathrm{MeHg}$ biogeochemistry. I addressed these questions with two closely related projects. The first, a broad observational survey of $\mathrm{MeHg}$ production and concentrations in stormwater and habitat wetlands, explored the extent of $\mathrm{MeHg}$ production in temperate artificial wetlands for the first time. In addition to answering this basic, open question, I also examined the spatial variations of $\mathrm{MeHg}$ concentrations in these wetlands, particularly as they related to vegetated and unvegetated areas and along the aquatic-terrestrial gradient. The results of this 
initial survey have been submitted to Environmental Pollution, and are presented in Chapter 2. Building on the results of this project, I focused my attention onto stormwater wetlands, which appeared to have an unusual pattern of $\mathrm{MeHg}$ production and accumulation. Furthermore, evidence from other systems (Feng et al., 2014; Oswald and Carey, 2016) suggested that extreme alterations in wetland hydrology, such as wetland draining during routine dredging operations, might stimulate MeHg production. Based on these results, I judged that there was a need to better understand $\mathrm{MeHg}$ biogeochemistry in stormwater wetlands, and to understand the effect of the management activities that are a fundamental part of the engineering of stormwater wetlands. To address these topics, I located similar wetlands at different points on the management life cycle, including a site that had recently been dredged. Using a wide range of techniques, I compared the $\mathrm{MeHg}$ biogeochemistry both between, and within, these wetlands across the growing season. The results of this work, currently being prepared for publication, are discussed in Chapter 3.

Concurrently with these investigations, I conducted a metataxonomic study of the impact of changes in sulfate deposition on the microbial community of a boreal peatland, a wetland type that has an enormous spatial extent and is impacted by very broad, but effective management in the form of legislated controls on the emission of atmospheric pollutants such as $\mathrm{SO}_{2}$, which is a precursor to sulfate in wet deposition (Kahl et al., 2004). This study capitalized on a long-term field manipulation of sulfate deposition to a small peatland in the Marcell Experimental Forest, Minnesota (Coleman Wasik et al., 2012; Jeremiason et al., 2006). In previous research, sulfate additions had been linked to increases in $\mathrm{MeHg}$ concentrations as a result of enhanced activity of sulfate reducing bacteria, one of the more important groups of $\mathrm{Hg}$ methylators (Gilmour et al. 1992, Gilmour et al. 2013). However, this field experiment also represented an opportunity to better understand how sulfate-mediated changes in the bacterial community structure might translate to increases or decreases in $\mathrm{MeHg}$. In addition, the impact of sulfate on bacterial community structure was, at that time, entirely unknown (Andersen et al., 2013). Realizing that these questions could be addressed simultaneously, I used a high-throughput sequencing approach to describe the entire bacterial community and quantitatively assessed its relationship to both sulfate depositional history and $\mathrm{MeHg}$ accumulation. Based on the understanding of the taxonomic distribution of $\mathrm{Hg}$ methylators in 2011, when this project began, I chose the Deltaproteobacteria as a coarse focus for identifying how sulfate deposition might alter the $\mathrm{Hg}$ 
methylating microflora. I obtained several interesting and novel results about the relationship of microbial community composition and structure to $\mathrm{MeHg}$ concentrations, and to changes in the deposition of sulfate. In addition, this project tentatively identified several novel Hg methylating taxa. This work has been published in Science of the Total Environment (Strickman et al., 2016), and is reprinted in Chapter 4.

At the outset of my $\mathrm{PhD}$ research, the established understanding of human $\mathrm{MeHg}$ exposure was that fish and seafood were the most significant dietary sources (Karagas et al., 2012; Mahaffey et al., 2003; Mergler et al., 2007). However, between 2011 and 2014 new lines of evidence converged to create a growing consensus that significant exposure to $\mathrm{MeHg}$ from eating rice, a low trophic level food, can occur in many areas (Rothenberg et al., 2014). Given the extremely large number of people who depend on rice as a staple food (Khush, 2005), it is vital that management interventions be based on sound understanding of where $\mathrm{MeHg}$ in rice plants originates. To fill this knowledge gap, I conducted the first controlled isotope tracer study mapping the source, uptake, and fate of both $\mathrm{MeHg}$ and inorganic $\mathrm{Hg}$ ( $\mathrm{IHg}$ ) in living rice plants. Serendipitously, this project also generated intriguing findings about the influence of plants on MeHg production in sediments. This chapter has also been published in Science of the Total Environment (Strickman and Mitchell, 2016), and is reproduced in Chapter 5. 


\section{Background and Literature Review}

\subsection{Hazards of Mercury and Methylmercury}

Methylmercury is a contaminant of global concern. Mercury is itself a hazardous substance, but when rendered more bioavailable by the addition of a methyl group, this heavy metal is readily accumulated and magnified in higher trophic organisms to levels manyfold higher than those in the environment (Engstrom, 2007; Fitzgerald et al., 1998). For this reason, $\mathrm{MeHg}$ is the focus of the greatest attention by scientists and policymakers. The neurotoxic effects of $\mathrm{MeHg}$ in humans have been well described, and can include tremors, visual and auditory problems, motor impairment, increased risk of epilepsy and mild to severe cognitive deficits depending on the dose, route, and age at exposure (Mergler et al., 2007; Yuan, 2012). Outside of famous mass poisonings in Minamata, Japan, and Grassy Narrows, Ontario, acute MeHg toxicity is rare, but adverse effects can be significant even at very low doses (Karagas et al., 2012), particularly if that exposure took place during a vulnerable developmental stage in utero or as an infant (Mergler et al., 2007). Despite extensive and well-publicized fisheries closures and fish consumption advisories (USEPA 2010), it is estimated that in the United States alone as many as 300,000 children are born each year who have been exposed in utero to levels of $\mathrm{MeHg}$ exceeding that considered safe (Mahaffey et al., 2003). The resulting subclinical intellectual impairment translates to lost earnings of up to 43.8 billion USD per year (Trasande et al., 2005). On a global scale, the total burden of $\mathrm{MeHg}$ to individuals, and to society, is difficult to quantify but is likely to be considerable (Mergler et al., 2007), particularly in the developing world where seafood is an important source of protein. Recently, it has also become apparent that humans eating a rice-based diet may be exposed to hazardous levels of $\mathrm{MeHg}$ through this lower-trophic level food (Li et al., 2015; P. Li et al., 2010; Zhang et al., 2010). This issues is of great concern, as more than half of the world's population consumes rice as a staple food (Khush, 2005). MeHg is also a health threat to wildlife, particularly to higher-trophic level organisms that depend on fish or aquatic insect prey. These species experience reproductive impairment, hormonal disturbances, behavioral changes, and acute toxicity. Many of the species most affected by $\mathrm{MeHg}$ are either important human food resources or species of conservation concern, or both (Eagles-Smith et al., 2016; Scheuhammer et al., 2007). 


\subsection{Mercury in the Environment}

\subsubsection{Sources, transformations, and fates of mercury in the global environment}

Mercury is released to the environment from both natural sources, including volcanoes, wildfires, and weathering of Hg-rich rocks, and human activities, such as fossil fuel combustion, waste incineration, mining, and several industrial processes (Cohen et al., 2004; Selin, 2009). In urban areas, $\mathrm{Hg}$ emitted from gasoline combustion on roadways can also be an important input (Eckley and Branfireun, 2008). Since the advent of the industrial revolution, there has been a threefold increase in $\mathrm{Hg}$ emissions (Driscoll et al., 2013), part of which is explained by cycling of increased deposition (Mason et al. 2002).

Over the last twenty years, $\mathrm{Hg}$ emissions have been reduced in Europe and North America (Pacyna et al., 2006), which is likely to have positive effects on MeHg loads in biota, but the speed of response is highly dependent on the landscape setting of aquatic systems (Harris et al., 2007; Jeremiason et al., 2006; Munthe et al., 2007). The long residence time of $\mathrm{Hg}$ in the biosphere, on the order of 3,000 to 10,000 years means that, from a practical perspective, elevated Hg levels are a permanent issue in many systems (Amos et al., 2013). In addition, the slow release of archived $\mathrm{Hg}$ from sediments means that historical or legacy contamination is an important problem in many areas (Davis et al., 2012; Eagles-Smith et al., 2016; Horvat et al., 2003; Munthe et al., 2007; Válega et al., 2008). Long range transport of $\mathrm{Hg}$ from areas with higher emissions may reduce the efficacy of local legislative solutions to $\mathrm{Hg}$ deposition (Jaffe and Strode, 2008), highlighting the importance of understanding and mitigating $\mathrm{MeHg}$ production in the total environment rather than relying on end-of-pipe measures.

Mercury is emitted and transported in solid, liquid, and gaseous phases, but atmospheric transport is the most significant from a global perspective (Fitzgerald et al., 1998) since it is the ubiquity and transportability as well as its toxicity that make $\mathrm{Hg}$ a pollutant of global concern. The fate of these emissions depends on their speciation. Elemental $\mathrm{Hg}_{\mathrm{g}} \mathrm{Hg}^{0}$, an unreactive form with a residence time in the atmosphere of $0.5-1$ years, is poorly removed from the air and may be transported long distances before it is oxidized by ozone or bromine to a more reactive form. This species dominates natural emissions and the atmospheric pool and exists at well- 
mixed background levels of 1.0-2.5 $\mathrm{ng} \mathrm{m}^{-3}$ (Temme et al., 2003). Anthropogenic releases also include c. $40 \%$ of two other species, divalent and particle-bound $\mathrm{Hg}$. Oxidized or divalent mercury, $\mathrm{Hg}^{\mathrm{II}}$, is highly water-soluble and sorbs easily to soot particles. It is easily scavenged from the sub-cloud air by precipitation or dry deposition and removed over a period of days to weeks (Cohen et al., 2004; Selin, 2009). Particulate Hg is emitted in particle-bound form and remains in the atmosphere for only a few days. Methylmercury can also volatilize and be transported atmospherically, but it composes less than one percent of either the atmospheric $\mathrm{Hg}$ pool or net deposition (Grigal, 2002; Selin, 2009; St. Louis et al., 1994).

Mercury leaves the atmosphere via dry deposition, wet deposition, and stomatal uptake into leaf tissues, which subsequently deliver this $\mathrm{Hg}$ to the soil when leaves are shed. Total global Hg deposition is difficult to quantify, because monitoring networks exist only in some areas and currently record only wet deposition (Travnikov, 2012; Wang et al., 2016). On a regional scale, $\mathrm{Hg}$ deposition in North America is monitored by the Mercury Deposition Network which observed annual wet deposition rates of 2-18 $\mu \mathrm{g} \mathrm{m}^{-2}$ in 2011 (NADP 2011); other studies have found rates in Ontario up to $35 \mathrm{ug} \mathrm{m}^{-2} \mathrm{a}^{-1}$ (Grigal, 2002). Between 5 and $60 \%$ of this deposition is quickly reemitted as $\mathrm{Hg}^{0}$ (Hintelmann et al., 2002). Most of the remainder is oxidized to $\mathrm{Hg}^{\mathrm{II}}$ and bound to reduced sulfur groups in soils, where it accumulates to background levels ranging from 50-100 $\mathrm{ng} \mathrm{g}^{-1}$ (Obrist et al., 2011). A substantial but poorly quantified proportion of terrestrial $\mathrm{Hg}$ is reduced to $\mathrm{Hg}^{0}$ and re-emitted, or liberated through combustion of biomass (Turetsky et al., 2006).

\subsubsection{Sources, transport and fate of mercury in the aquatic environment}

Depending on the landscape, about five to fifty percent of $\mathrm{Hg}$ deposited to a terrestrial watershed eventually migrates, sometimes over a period of many years, to the water basin (Grigal, 2002; Hintelmann et al., 2002; St. Louis et al., 2004) often in pulses associated with rainfall or snowmelt (Dittman et al., 2010; Eckley and Branfireun, 2008; Haynes and Mitchell, 2012). Waterways also receive $\mathrm{Hg}$ directly from the atmosphere through wet or dry deposition. Once it has reached the aquatic environment, $\mathrm{Hg}$ may remain in the water column, where it can be oxidized to bioavailable $\mathrm{Hg}^{\mathrm{II}}$ by the photochemically produced $\mathrm{OH}$ radical, or be deposited to the sediment where it sorbs strongly to organic matter and metal oxides. Most $\mathrm{Hg}$ remains sequestered in the benthic layer, but it may also dissolve back into porewater or the overlying 
water column, or be resuspended along with the particulate matter to which it is bound (Selin, 2009). Mercury is present as two species in aquatic environments, $\mathrm{Hg}^{0}$ and $\mathrm{Hg}^{\mathrm{II}}$, the latter of which forms many different aqueous mercury-ligand complexes with reduced sulfur, chloride, hydroxides or organic carbon (Benoit, 2003). In sulfate-rich marine waters $\left(2,700 \mathrm{mg}^{-1}\right)$, sulfide controls $\mathrm{Hg}$ speciation, while in freshwater, which usually contains low levels of sulfate (10 mg $\mathrm{1}^{-1}$ ), dissolved organic matter, chloride or hydroxide are more important ligands (Benoit, 2003; Mitsch and Gosselink 2007). Mercury may also be coordinated to cation binding sites on soil particles. In aquatic systems, all of the $\mathrm{Hg}$ species present, collectively referred to as total mercury or $\mathrm{THg}$, occur in a mixture of dissolved, nanoparticulate, colloidal, and particulate size fractionations (Hsu-Kim et al., 2013). Nanoparticulate mercury may be an important modulator of bioavailability, discussed further below. Mercury is lost from aquatic environments through transport downstream either in dissolved or particulate-bound forms, groundwater flow, volatilization of $\mathrm{Hg}^{0}$ from the water surface, as part of the transpiration stream of aquatic plants (Branfireun et al. 1996; Lindberg et al., 2005), or efflux as part of the MeHg body burden of mobile organisms (Tremblay et al., 1998).

Wetlands, including peatlands, ponds, lake margins, salt and freshwater marshes, and estuaries, are important sites of $\mathrm{Hg}$ methylation. The production of $\mathrm{MeHg}$ in these sites is a complex process mediated by activity and identity of the microbial community, $\mathrm{Hg}$ bioavailability, the dynamic balance of $\mathrm{Hg}$ methylation and demethylation and the physicochemical and ecological parameters that influence these processes. Although $\mathrm{Hg}$ methylation can occur in other environments, such as upland soil, rates of production are much higher in wetlands and the total $\mathrm{MeHg}$ flux to a water body can be predicted by the proportion of wetlands in its catchment (Munthe et al., 2007; St. Louis et al., 1994), a relationship which holds true over many wetland types and climatic zones (Grigal, 2002; Hall et al., 2008). As well as net flux, $\mathrm{MeHg}$ concentration in water rises by $0.01-0.03 \mathrm{ng}^{-1}$ for each additional percent of a watershed covered by wetlands (Driscoll et al. 1994; Grigal 2002). Net efflux of MeHg from these sites varies according to season and hydrology, with high concentrations usually leaving the wetland in the summer (Rudd 1995), and during a storm event (Branfireun et al., 1996). 


\subsection{The Wetland Environment}

\subsubsection{Wetland hydrology and biogeochemistry}

Aspects of permanent freshwater wetlands which are most relevant for an understanding of $\mathrm{Hg}$ biogeochemistry are briefly reviewed here. Firstly, the timing and periodicity of water inputs to a wetland, or hydroperiod, is a fundamental driver of many aspects of its biogeochemistry, including the supply of $\mathrm{Hg}$ and other pollutants. Surface inflows, which supply the bulk of nutrients, pollutants, and suspended matter, are often seasonal and pulsed in conjunction with storm events or snowmelt (Junk et al. 1989). The volume of suspended and dissolved materials that can be transported is related positively to water velocity. Once it arrives in a wetland, water flow slows, and remains in a wetland for a period, known as the residence time, which relates negatively to the average water volume and flow rate. Within the wetland, suspended particles, including $\mathrm{Hg}$ sorbed to particulate matter or precipitated with sulfides or other ligands, settle out of solution (Scholz and Lee, 2005). Although residence times in wetlands vary greatly, they are almost always longer than that in a similar sized volume of river or stream, making wetlands net sinks for many materials including pollutants and nuisance nutrients and providing an explanation for the role of wetlands as sources of $\mathrm{MeHg}$ at the landscape scale (Branfireun et al., 1996; Brix, 1994; Grigal, 2002; Hall et al., 2008). The movement of subsurface water, or porewater, through saturated wetland sediments is a strong control on the movement of solutes between environmental compartments. The hydraulic connectivity of wetland sediments is inversely related to particle size, with fine or compacted sediment particles allowing little movement of porewater, while coarse and loosely packed particles promote the movement of water (Mitsch and Gosselink, 2007).

The availability of terminal electron acceptors in wetland sediments is a strong structuring force in the biogeochemistry of wetland sediments, forming a characteristic series of layers related to differences in redox potential which have important implications for the MeHg cycle. After soil is inundated, anaerobic conditions develop over days or weeks. Oxygen diffuses inefficiently in waterlogged sediments, and is rapidly consumed by soil microorganisms (Ponnamperuma 1972). Typically, the oxidized layer extends for only a few millimeters, although this depth can extend downward in sediments that are hydraulically rough, overlaid by turbulent water, disrupted by bioturbation, very poor in organic matter substrates, or supplied with autochthonous oxygen from 
photosynthetic soil microorganisms or radial oxygen loss from plant roots (Brune et al. 2000; Mendelssohn et al., 1995). In this zone, where redox values range between +400 and $+600 \mathrm{mV}$, oxygen is the dominant electron acceptor. Molecular oxygen also abiotically oxidizes iron and sulfur to their oxidized forms ferric iron $\left(\mathrm{Fe}^{\mathrm{III}}\right)$ and sulfate $\left(\mathrm{SO}_{4}{ }^{2-}\right)$ respectively. These molecules may then diffuse downward, where they provide substrate for iron and sulfate reducing bacteria, which host the best-studied Hg methylators (Gilmour et al., 2013; Podar et al., 2015). In particular, sulfate-reducing bacteria have been identified as important methylators in a wide range of environments (Acha et al., 2005; Eckley et al., 2015; Gilmour et al., 1992), making the availability of this metabolic substrate extremely important in modulating $\mathrm{MeHg}$ production in the environment.

Facultative and obligate anaerobic bacteria, which encompass all known Hg methylators (Gilmour et al., 2013), inhabit the oxygen-free sediments below the oxic layer. As a result of the proximity of oxygenically regenerated ferric iron and sulfate and anaerobic soil microhabitats, the top layers of the sediment profile are usually the most important for $\mathrm{Hg}$ methylation (Eckley et al., 2015; Goulet et al., 2007). Nitrate is reduced to nitrite when redox levels fall to $250 \mathrm{mV}$, while the reduction of manganic to manganous compounds becomes metabolically profitable at about $225 \mathrm{mV}$. At redox potentials of about +100 to $-100 \mathrm{mV}$, iron is reduced from ferric to ferrous forms, fueling the metabolism of iron reducing bacteria (Mitsch and Gosselink 2007).

Below this lies the sulfidic layer, where the sulfate reducing bacteria convert sulfate to sulfide (Jorgenson 1977), one of the most aggressive ligands of Hg (Compeau and Bartha, 1983). Sulfate reducing bacteria were once considered strict anaerobes, but new evidence suggests they can survive exposure to oxygen and persist in anoxic microsites (Faulwetter et al., 2012). Sulfide and methane diffuse upward, where they are reoxidized either abiotically or through the activities of sulfide or methane oxidizing bacteria, which pair this process with the reduction of ferrous or manganous ions (Brune et al. 2000).

At the deepest and most reduced layers the exhaustion of other electron acceptors and very high electron pressures $(-200 \mathrm{mV})$ allow organic matter or carbon dioxide to be used for energy production by obligate methanogenic archaea, a prokaryote group distinct from the Eubacteria (Olsen and Woese 1997), and from which several confirmed Hg methylators have been identified 
(Gilmour et al., 2013; Hamelin et al., 2011). Methanogenic archaea are obligate anaerobes which are rapidly disabled by oxygen. Methane produced here diffuses upwards to the oxygenated layer, where is oxidized by obligate methanogenic bacteria or is discharged to overlying waters or the atmosphere (Brune et al. 2000; Conrad, 1996).

\subsubsection{Wetland Plants}

The presence of wetland plants modulates the functioning of the wetland, with potentially important impacts on its Hg biogeochemistry. Wetland plants alter the wetland's hydrology by providing hydraulic drag, which slows water flow, prevents erosion and resuspension, and increases the precipitation of suspended particles (Brix, 1997), all processes which can influence the net import and export of MeHg (McCord and Heim, 2015). The potential influence of plants on $\mathrm{Hg}$ biogeochemistry, however, is most strongly related to their impact on wetland microbiology. Wetland plants support the respiratory needs of their roots via specialized air transmitting tissues or pressure driven gas exchange. Some of this oxygen is lost from roots, oxidizing the rhizosphere to a distance of up to $20 \mathrm{~mm}$. This effect, termed radial oxygen loss, strongly alters the redox conditions of the rhizosphere and is most pronounced in zones of rapid root growth (Brix, 1994). The spatially complex root architecture creates mosaics of redox conditions that allow the coexistence of many metabolic guilds and enhancing microbial density, activity, and diversity (Faulwetter et al. 2007). Radial oxygen loss may liberate metals from precipitates and regenerate sulfate and ferrous iron substrates of $\mathrm{Hg}$ methylating bacteria, thus potentially increasing Hg methylation (Doyle and Otte, 1997; Jacob and Otte, 2003). Conversely, in densely rooted areas the aerobic environment created would be more likely to decrease methylation, by limiting the anoxic conditions required by $\mathrm{Hg}$ methylators, or by increasing demethylation, a process that proceeds more quickly in aerobic environments (Lin et al., 2012; Ullrich et al., 2001). Plant roots also leak a wide variety of labile organic carbon compounds (Marschner, 1995), including organic acids which liberate micronutrient cations, including Hg, from binding sites in the wetland sediments (Jacob and Otte, 2003), as well as fueling the metabolism of rhizosphere bacteria, including Hg methylators (Windham-Myers et al., 2009). However, these organic ligands released by plant roots may also bind to IHg, lowering its bioavailability for methylation (Cosio et al., 2014). 


\subsection{The Methylmercury Cycle}

\subsubsection{Physical location of mercury methylation in the aquatic environment}

Once it has entered the freshwater aquatic habitat, $\mathrm{Hg}$ can be methylated abiotically in the photic zone of the water column (Siciliano et al., 2005) but in the majority of freshwater habitats, net $\mathrm{Hg}$ methylation proceeds most vigorously through the action of anaerobic prokaryotes (Gilmour et al., 2013; Jensen and Jernelöv, 1969; Podar et al., 2015; Robinson and Tuovinen, 1984) in anoxic habitats and microsites, including stratified water masses, periphyton biofilms, aquifers and groundwater, and in benthic sediments (Corriera et al., 2012; Derosiers et al., 2005; Guimarães et al., 2006; Podar et al., 2015). Significant Hg methylation has also been observed in the aerobic root zone of floating macrophytes (Acha et al., 2005), which may have been due to unknown, aerobic methylators or to methylation in anaerobic microsites in the biofilm matrix. In temperate climates, the interface between the water and benthic sediment appears to be the zone of most active $\mathrm{Hg}$ methylation (Goulet et al., 2007; Gilmour et al., 1992). This is likely due to the proximity of oxic and anoxic zones, allowing the obligate anaerobic $\mathrm{Hg}$ methylators to access aerobically regenerated metabolic substrates, particularly sulfate and ferric iron, as well as labile organic carbon sourced from benthic primary productivity or newly deposited detritus (Eckley et al., 2015; Mitchell and Gilmour, 2008). Benthic sediment is also the largest and most consistently anoxic compartment in most wetland systems, and the location of most of the $\mathrm{Hg}$ load (Gilmour et al., 1992). Porewater and sediment concentrations of $\mathrm{MeHg}$ are usually much higher than that in overlying water (Holmes and Lean, 2006) and correlate well with loads in biota, while concentrations in overlying water do not (Sinclair et al., 2012). Most research on $\mathrm{MeHg}$ biogeochemistry thus focuses on the sediment and porewaters.

\subsubsection{The taxonomic distribution of mercury methylation capacity}

Mercury methylation is carried out by at least one gene pathway, the $h g c A B$ gene cluster was discovered in 2013 (Parks et al., 2013). Although the mechanistic details of this pathway have not been fully determined, it appears that the methyl group originates from methyltetrahydrofolate and is transferred to the $h g c A$ corrinoid protein via a methyltransferase from the acetyl-coA pathway or an unknown enzyme. The $h g c A$ corrinoid then attaches this methyl group to $\mathrm{Hg}^{\mathrm{II}}$ ion which may be bound to cytoplasmic thiols or cysteine residues. The corrinoid 
protein is subsequently reduced and regenerated by the $h g c B$ ferredoxin. The biological reason for $\mathrm{Hg}$ methylation is not apparent, as $\mathrm{MeHg}$ serves no known biological function and is potently toxic. Observations of a close relationship between intracellular $\mathrm{MeHg}$ production and efflux in pure culture (Schaefer et al., 2011) and enrichment of highly Hg-contaminated sites with $\mathrm{Hg}$ methylating strains (Vishnivetskaya et al., 2010) suggest that the process may be a detoxification mechanism, although the high toxicity of $\mathrm{MeHg}$ and its proclivity to bind to cell surfaces are strong counterarguments (Lin et al., 2012).

Orthologues of the $h g c A B$ pathway have been identified in all $\mathrm{Hg}$ methylators for which a genome is available, and have also been used to hypothesize potential $\mathrm{Hg}$ methylators based on genome sequences in publicly available databases (Gilmour et al., 2013; Podar et al., 2015). Several decades of work have identified, or strongly suggested methylation ability in a diverse range of microorganisms. These include members of the sulfate reducing (Compeau and Bartha, 1985) iron reducing (Fleming et al., 2006; Kerin et al., 2006) and syntrophic (Bae et al., 2014) Deltaproteobacteria, metabolically diverse Firmicutes (Gilmour et al., 2013), methanogenic archaea (Hamelin et al., 2011), syntrophic Chloroflexi (Bae et al., 2014) and a marine nitrite oxidizer (Gionfriddo et al., 2016). Metataxonomic approaches have identified consortia of syntrophic Hg methylators, suggesting that the $h g c A B$ gene complex is transmitted through horizontal as well as vertical gene transfer (Bae et al., 2014; Podar et al., 2015). However, it should be emphasized that methylation ability is not consistently found in every member of a clade but rather is species or even strain specific (Bridou et al., 2011; King et al., 2000; Ranchou-Peyruse et al., 2009).

The capacity of methylate $\mathrm{Hg}$ in the environment has been confirmed in a more limited subset of taxa. Sulfate reducing bacteria have been the best studied $\mathrm{Hg}$ methylators, and their relevance to $\mathrm{Hg}$ methylation confirmed by sulfate amendment and metabolic inhibition studies at scales from laboratory cultures to long term field manipulations (Acha et al., 2005; Branfireun et al., 1999; Compeau and Bartha, 1985; Gilmour et al., 1992; Harmon et al., 2004; Jeremiason et al., 2006). Other work has found that in specific environments, $\mathrm{Hg}$ methylation is carried out predominantly by iron reducers (Fleming et al., 2006; Warner et al., 2003) or methanogens (Hamelin et al., 2011). In addition, synergistic and syntrophic interactions between different members of the microbiota have been observed in several settings, suggesting that microbial community 
structure is also important for regulating MeHg production. For instance, Pak and Bartha (1998) observed that methanogen-driven degradation of $\mathrm{H}_{2}$ and acetate, both byproducts and metabolic inhibitors of sulfate reducing bacteria, increased $\mathrm{Hg}$ methylation from undetectable rates to $2.6 \%$ over eight days, while Macaladay et al. (2000) identified a relationship between the structure of the microbial community and $\mathrm{MeHg}$ accumulation in a mercury polluted lake. As of 2011, however, modern next generation sequencing techniques had not yet been applied to this question.

All Hg methylators for which ecological data is available are microaerophiles, facultative anaerobes, or obligate anaerobes (Gilmour et al., 2013; Gionfriddo et al., 2016). In silico searching for the ecological distribution of hgc $\mathrm{AB}$ has found examples in a very broad range of anaerobic, but not aerobic, habitats (Gilmour et al., 2013). Therefore, the established consensus is that $\mathrm{Hg}$ methylation ability is confined to anaerobic environments. However, since whole genome sequences are not available for all known methylators, far less a representative distribution of prokaryotes, the existence of methylators in other groups cannot be excluded.

\subsubsection{Mercury bioavailability and uptake by mercury methylators}

Mercury methylation is an intracellular process (Gilmour et al., 2011; Schaefer et al., 2011) and the supply of mercury substrate the major limitation (Graham et al., 2012b; Schaefer et al., 2011). However, only divalent $\mathrm{Hg}$ is available for uptake, and in natural waters, this ion exists in many complexes, only a subset of which are truly bioavailable. Neither this subset, nor the speciations and relative concentrations of $\mathrm{Hg}$ in natural waters, have been completely described, and cannot be easily predicted. As a result, neither concentrations of total $\mathrm{Hg}$ nor $\mathrm{Hg}^{\mathrm{II}}$ can be used to reliably predict Hg methylation (Benoit 2003, Hsu-Kim et al., 2013).

The bioavailable fraction of $\mathrm{Hg}$ depends on the uptake mechanism. Proposed methods of $\mathrm{Hg}^{\mathrm{II}}$ uptake include passive diffusion of lipophilic, neutrally charged complexes, facilitated diffusion of neutral and ionic $\mathrm{Hg}$ complexes, active transport, or transport as part of the mer $\mathrm{Hg}$ demethylation system (Hsu-Kim et al. 2013). The latter pathway is not found in anaerobic bacteria (Barkay et al., 2003) and is not relevant to Hg uptake for methylation. Until fairly recently, passive diffusion of uncharged $\mathrm{Hg}$ complexes was accepted as the main route of $\mathrm{Hg}$ uptake (Barkay et al. 1997). 
There is evidence both for and against the passive uptake mechanism in sulfate reducing bacteria (Benoit et al., 1999; Graham et al., 2012b; Schaefer et al., 2011) but recent evidence indicates that active uptake through an unknown mechanism is more important in iron reducing $\mathrm{Hg}$ methylators and that $\mathrm{Hg}$ bound to small thiols, particularly cysteine, may improve $\mathrm{Hg}$ bioavailability for this group (Schaefer et al., 2011; Schaefer and Morel, 2009) although it is also possible that rather than facilitating uptake, thiols prevent the sorption of $\mathrm{Hg}$ to suspended particles (Graham et al., 2012a; Zhang et al., 2012). In the absence of a firm understanding of the mechanics of $\mathrm{Hg}$ uptake, it remains difficult to identify and quantify the bioavailable geochemical fraction of $\mathrm{Hg}^{\mathrm{II}}$. Currently, $\mathrm{Hg}$ bioavailability is best assessed functionally, as the rate of methylation of an isotopic $\mathrm{Hg}$ tracer.

\subsubsection{Mercury methylation rates and measurement techniques}

Mercury methylation can be measured with directly in sediments, waters, and microbial cultures. The methods for assessing $\mathrm{Hg}$ methylation are predominately based on the use of stable isotope tracers. Mercury exists as seven stable isotopes with atomic masses of 196, 198, 199, 200, 201, 202, and 204, which, when obtained in enriched form, can be used as tracers in measurements of $\mathrm{MeHg}$ production, allowing the calculation of $\mathrm{Hg}$ methylation rate constants $\left(\mathrm{K}_{\text {meth }}\right)$ (Hintelmann et al., 1995; Hintelmann and Evans, 1997; Yin et al., 2014). It should be noted, however, that newly added $\mathrm{Hg}$ is more bioavailable than that naturally present in the sample, with the result that these rates represent the potential $\mathrm{Hg}$ methylation capacity of the sample, rather than an absolute quantification (Hintelmann et al., 2000). An additional drawback to this approach is that the identity of key methylating organisms can only be assessed very roughly through measurements of metabolic by-products (Mitchell and Gilmour, 2008) or correlations between abundance of different taxa and rates of $\mathrm{Hg}$ methylation (Mosher et al., 2012; Yu et al., 2010). Mercury methylation measurements from pure culture are the only way to be sure of the taxonomic identity of the methylator, but do not account for methylation or demethylation by other organisms, natural $\mathrm{Hg}$ speciation or intraspecies interactions, and so may not predict $\mathrm{MeHg}$ production in the natural world (Gilmour et al., 2013).

Methylation rate constant measurements are technically demanding and relatively expensive in comparison to the measurement of the total $\mathrm{MeHg}$ content of a sample. For this reason, the percent of $\mathrm{Hg}$ present as $\mathrm{MeHg}(\% \mathrm{MeHg})$, a value which integrates methylation and 
demethylation processes, is often used to compare the contamination or production capacities of different environments, although it cannot account for archived $\mathrm{MeHg}$, or $\mathrm{MeHg}$ efflux from the sediment (Drott et al., 2008). The overall MeHg productivity of a wetland site is variously assessed by $\mathrm{MeHg}$ production or accumulation in sediment, porewaters, or overlying waters; efflux from a defined outflow; or bioaccumulation in one or more trophic levels. Very recently, the publication of primers optimized for the detection of $h g c A B$ in diverse taxonomic groups in natural samples (Christensen et al., 2016), with subsequent sequencing and identification, has allowed the simultaneous identification of in situ $\mathrm{Hg}$ methylators, and estimation of their activity.

\subsubsection{Demethylation}

In the photic zone, photolysis is an important degradation pathway for $\mathrm{MeHg}$, while biotic demethylation dominates outside this region. Biotic demethylation can be divided into two categories: reductive demethylation, which produces methane and $\mathrm{Hg}^{0}$, and oxidative demethylation, with $\mathrm{CO}_{2}$ and bioavailable $\mathrm{Hg}^{\mathrm{II}}$ as the end products. Oxidative demethylation is believed to be a cometabolism of $\mathrm{Hg}$ with the small organic methyl group, while reductive demethylation is an active, inducible $\mathrm{Hg}$ detoxification pathway that is carried out by the merA and mer $B$ genes. In this pathway, the mer $B$ enzyme cleaves methane from $\mathrm{MeHg}$ producing $\mathrm{CH}_{3}$ and $\mathrm{Hg}^{\mathrm{II}}$. This divalent $\mathrm{Hg}$ is then reduced by the $m e r A$ enzyme to volatile $\mathrm{Hg}^{0}$, which evades from the system (Barkay et al., 2003). Mercury demethylation ability is widely distributed and proceeds most robustly in oxic environments, although it also occurs under anaerobic conditions (Lin et al., 2012; Ullrich et al., 2001). Oxidative demethylation may be the dominant pathway in less contaminated environments, while mer-mediated reductive demethylation appears to be more common when MeHg is present at higher concentrations (Marvin-DiPasquale et al., 2000).

\subsubsection{Methylmercury bioaccumulation}

As previously discussed, much of the human exposure to $\mathrm{MeHg}$ occurs by consumption of contaminated fish, seafood, and marine mammals. In animal tissues, $\mathrm{MeHg}$ is almost completely taken up in food rather than directly from water (Hall et al., 1997). The initial transfer from the environment to plankton and zooplankton represents a $10^{4}-10^{6}$ fold increase (Pickhardt et al., 2002). It is also likely that $\mathrm{Hg}$ methylation within the periphyton, communities of 
microorganisms growing attached to the sessile substrates, may be an important entry point for MeHg to the food chain (de Wit et al., 2012; Tsui and Finlay, 2011).Both the total Hg burden, and the percent of $\mathrm{Hg}$ in an organism present as $\mathrm{MeHg}$ increase with trophic levels in invertebrates, fish, and mammals (de Wit et al., 2012; Edmonds et al., 2012; Hall et al., 1997; Wagemann et al., 1998). In fish, MeHg accumulation also varies between individuals of the same species, which may be driven by differences in prey consumption rate (MeHg input) and growth efficiency (the ratio of MeHg to nutrients and thus growth) (Mathews and Fisher, 2008). In birds and mammals, as well as fish, MeHg burden increases with the organism's age (Burgess and Meyer, 2007; Ward et al., 2010), although somatic growth dilution and the production of eggs or live young can lead to a temporary reduction in total concentration of this, and many other persistent contaminants (deBruyn and Gobas, 2006; Karimi et al., 2007). In addition, poorlyunderstood detoxification mechanisms moderate $\mathrm{MeHg}$ toxicity in some species, such as mink (Scheuhammer et al., 2007) or beluga, ringed seals, and narwhals (Wagemann 1998).

Bioaccumulation of $\mathrm{MeHg}$ in plant tissues has been little studied in comparison to uptake to animals, since until recently, it was believed that dietary $\mathrm{MeHg}$ risk to humans was confined to organisms at or near the top of aquatic foodchains. However, $\mathrm{Hg}$ methylation occurs actively in rice paddies (Liu et al., 2014; Rothenberg and Feng, 2012), and MeHg in rice tissues can reach levels up to 34 (mean 5.5) times higher than in the surrounding environment (Rothenberg et al., 2014), making this staple food a significant dietary source of $\mathrm{MeHg}$ to human populations living in areas where rice cultivation and $\mathrm{Hg}$ contamination occur together (Zhang et al., 2010). Methylmercury in plant tissues appears to behave as a mobile nutrient, likely due to its binding to free cysteine moieties (L. Li et al., 2010). During grain filling, $\mathrm{MeHg}$ is translocated from other plant tissues and incorporated to proteins alongside the cysteine residue to which it is bound (B. Meng et al., 2014), reaching levels as high as $56 \mathrm{ng} \mathrm{g}^{-1}$ in contaminated areas (Rothenberg et al., 2014). MeHg accumulation in rice grains varies between rice cultivars and in response to environmental conditions (Li et al., 2013; Rothenberg et al., 2012), the supply of IHg (M. Meng et al., 2014), and the structure and activity of the $\mathrm{Hg}$ methylating microflora (Liu et al., 2013). In addition, the hydrologic conditions of the rice paddy alter $\mathrm{MeHg}$ accumulation, with water drawdown events or aerobic rice cultivation reducing $\mathrm{MeHg}$ production and accumulation in rice (Peng et al., 2012; Wang et al., 2014). Correlative studies suggest that the soil is the origin of MeHg to rice plants (Meng et al., 2011; M. Meng et al., 2014), but it is also 
possible that MeHg may be methylated in planta or taken up from the water (Cosio et al., 2014; Rothenberg et al., 2014). In planta demethylation and loss from the plant in the transpirational stream (Xu et al., 2016) represents a potential detoxification pathway.

\subsubsection{Environmental factors correlating with mercury methylation}

In the absence of a reliable way to measure the bioavailable fraction of available $\mathrm{Hg}$, a robust understanding of the taxonomic breadth of $\mathrm{Hg}$ methylators, or, until recently, of a confirmed pathway of $\mathrm{Hg}$ methylation, an empirically defined suite of environmental parameters that correlate with efficiency of $\mathrm{Hg}$ biotransformation has been identified. Some of these relate to the metabolic needs of $\mathrm{Hg}$ methylating organisms, including a positive interaction with anoxia, higher temperature, and sulfate (Benoit et al., 2003; Munthe et al., 2007; Ullrich et al., 2001). Sediment organic matter is usually related positively to $\mathrm{Hg}$ and $\mathrm{MeHg}$ concentrations, as a result of the high affinity of $\mathrm{Hg}$ for thiol binding sites on humic organic matter (He et al., 2007; Meng et al., 2016; Obrist et al., 2011; Skyllberg et al. 2000). Other factors are related to the bioavailability of $\mathrm{Hg}$, such as a negative relationship between $\mathrm{Hg}$ methylation and concentrations of sulfide, which removes $\mathrm{Hg}$ from solution by precipitation as $\mathrm{HgS}_{\mathrm{s}}$ (Benoit et al. 1999; Mitchell and Gilmour 2008) and also shifts the speciation of $\mathrm{Hg}$ compounds to charged, likely lesser bioavailable species (Liu et al., 2012). Similarly, environments with a $\mathrm{pH}$ of $<7$ to 5 host

higher rates of $\mathrm{Hg}$ methylation (Ullrich et al., 2001), which may be due to liberation of $\mathrm{Hg}^{\mathrm{II}}$ from dissolved organic matter ligands (Amirbahman et al. 2002). Newly deposited Hg has been repeatedly observed to be more bioavailable for methylation (Harris et al., 2007; Hintelmann et al., 2002; Mao et al., 2013; Peng et al., 2012; Schwesig and Krebs, 2003), which may be related to the size fractionation of newly added $\mathrm{Hg}$, which is mostly bound in nanoparticulate (less than $0.45 \mu \mathrm{m}) \mathrm{Hg}$ sulfide (HgS) particles (Zhang et al., 2012). As Hg ages, nanoparticles may coalesce into large colloids or crystalline $\mathrm{HgS}$ compounds, rendering it less available for uptake by Hg methylating microorganisms (Graham et al., 2012a,b). Newly created MeHg has also been repeatedly observed to be more available for bioaccumulation (Harris et al., 2007; Mao et al., 2013; Peng et al., 2012). Environments subjected to repeated cycles of wetting and drying also have increased rates of $\mathrm{Hg}$ methylation (Compeau and Bartha, 1985; Gilmour et al., 2004; Gustin et al., 2006) which may be mediated by oxidation of reduced sulfur compounds to sulfate with concomitant stimulation of sulfate reducing Hg methylators (Feng et al., 2014; Oswald and 
Carey, 2016). Finally, high concentrations of nitrate in benthic and porewaters can reduce $\mathrm{MeHg}$ production in some cases as a result of competitive inhibition of sulfate reducing bacteria by nitrate reducers (Shih et al., 2011; Todorova et al, 2009).

The causes of other empirically defined environmental factors linked to Hg methylation are less apparent. Although $\mathrm{Hg}$ and $\mathrm{MeHg}$ accumulation usually increase alongside sediment organic matter, there is a general negative relationship between dissolved organic matter and $\mathrm{Hg}$ methylation. This is likely a result of the formation of large Hg-organic carbon compounds, which are too large to be easily assimilated by Hg methylators (Hammerschmidt et al., 2008; Ravichandran, 2004). However, complexation of IHg with smaller particles of organic matter may facilitate uptake and methylation (Graham et al., 2012a). Additionally, recent work on nanoparticle fractions of $\mathrm{Hg}$ compounds suggest they may be extremely bioavailable (Graham et al. 2012a; Zhang et al. 2012) and that organic matter may help catalyze their formation and prevent their agglutination to larger, much less bioavailable masses (Graham et al. 2012a).

In response to these various factors, $\mathrm{MeHg}$ production varies between freshwater wetland environments over an order of magnitude (Hoggarth et al., 2015), highlighting the need to understand the $\mathrm{MeHg}$ production capacity of different wetlands rather than assuming a baseline rate of production. Unfortunately, as discussed in this and previous sections, $\mathrm{MeHg}$ biogeochemistry remains incompletely understood, impairing our ability to predict and manage production of this dangerous toxicant.

\subsubsection{Relationship of wetland plants to $\mathrm{MeHg}$ biogeochemistry}

Wetland plants may be an important modulator of $\mathrm{Hg}$ methylation (Section 1.3.2), with the bulk of the evidence suggesting that plants stimulate MeHg production (Cosio et al., 2014). Positive correlations between plant presence and $\mathrm{MeHg}$ production and accumulation have been observed in both freshwater (Bachand et al., 2014; Regier et al., 2012; Windham-Myers et al., 2009) and marine systems (Canário et al., 2007; O’Driscoll et al., 2011), as well as in rhizobox laboratory experiments (Sun et al., 2011). This effect has been attributed to release of labile organic carbon from plant roots (Windham-Myers et al., 2014, 2009), evapotranspiration-driven concentration of $\mathrm{MeHg}$ in porewaters (Bachand et al., 2014), increases in acidity which liberate IHg substrate from binding sites in the sediment (Jacob and Otte, 2003; Rothenberg and Feng, 2012), or 
reoxidation of the electron acceptors of $\mathrm{Hg}$ methylators (Rothenberg et al., 2014). Some evidence suggests that plants may also enhance $\mathrm{Hg}$ by alteration of the rhizobial community to include larger proportions of clades known to contain Hg methylators (Cosio et al., 2014; Regier et al., 2012). Interestingly, it is possible that the effect of plants on $\mathrm{Hg}$ methylation may be related to plant life stage (Sun et al., 2011), although the reasons for this are not clear.

The presence and identity of wetland plants has also been speculatively linked to lower rates of mercury methylation and export. King et al. (2002) observed lower rates of methylmercury export and porewater $\mathrm{MeHg}$ loads in treatment wetland microcosms colonized by the submergent aquatic Potamageton pusillis, which they hypothesized bound mercury to its floating biomass or improved conditions for demethylation through aeration of the upper sediment. Sinclair et al. (2012) hypothesized that the patterns they observed of decreasing MeHg loads in sediment and biota in older wetlands, was due to the deepening oxic layer of these environments, as evidenced by increasing concentrations of oxidized iron $\left(0.5 \mathrm{~N}-\mathrm{HCl}\right.$ extractable $\left.\mathrm{Fe}^{\mathrm{III}}\right)$, and could be explained by the lack of rhizosphere-oxidizing plants in very young wetlands. However, these lines of evidence are less robust than those supporting the stimulation of $\mathrm{MeHg}$ by wetland plants.

\subsubsection{Variation in mercury methylation between and within freshwater wetlands}

Methylmercury concentrations vary within a given location over fine spatial scales, highlighting the importance of sampling at more than one point within a wetland in order to avoid over- or under- estimating the $\mathrm{Hg}$ and $\mathrm{MeHg}$ loads of that environment (Ulanowski and Branfireun, 2013). Investigations of fine-scale variation can also elucidate locally important drivers of $\mathrm{MeHg}$ production and concentrations, for example in studies which have linked local differences in groundwater flow and sulfate inputs (Coleman Wasik et al., 2015, 2012; Jeremiason et al., 2006; Mitchell et al., 2008). The periphyton has been well researched as a zone of increased $\mathrm{Hg}$ methylation in tropical (Acha et al., 2005) and temperate (Gentès et al., 2013; Guimarães et al., 2006) areas, suggesting that this environmental compartment may be an important entry point for $\mathrm{MeHg}$ into the food chain. As discussed above, $\mathrm{Hg}$ methylation is often higher in vegetated portions of a wetland, and at the oxic-anoxic interface. 
Temporal variations in MeHg production and concentrations also occur. Newly created wetlands have been found to produce $\mathrm{MeHg}$ at extremely high rates. This early-life spike in $\mathrm{MeHg}$ production has been observed in many artificial wetlands including hydroelectric reservoirs, where it is often accompanied by an increase in fish MeHg loads (Mailman et al., 2006); an experimental reservoir which experienced a jump in $\mathrm{MeHg}$ efflux from $1.7 \mathrm{mg} \mathrm{ha}^{-1}$ year ${ }^{-1}$ to 70 $\mathrm{mg} \mathrm{ha}^{-1}$ year $^{-1}$ following floodup (St. Louis et al., 2004); an experimental wetland where a 26fold increase in $\mathrm{MeHg}$ export relative to pre-flooding output was observed (Rudd 1995); constructed habitat wetlands where \% $\mathrm{MeHg}$ was 2.4 times higher in a new wetland than in wetlands 3 years or more old (Sinclair et al., 2012); and large wastewater treatment wetlands, where $\mathrm{MeHg}$ water levels exceeded regulatory criteria for two years (Rumbold and Fink, 2006). A survey of beaver impoundments, which might be described as naturally created wetlands, also observed higher production of MeHg in younger ponds (Roy et al., 2009). This phenomenon appears to result from the decay of submerged organic mass and subsequent stimulation of microbial activity (Hall et al., 2005; Mailman et al., 2006).

In addition to temporal and spatial variations, wetland hydrology can alter $\mathrm{MeHg}$ biogeochemistry within an individual wetland. Spikes in MeHg production or concentrations have been observed when a dry season or drought is succeeded by wetter conditions (Coleman Wasik et al., 2015; Holloway et al., 2009) or when a normally terrestrial margin of a wetland is inundated in a high water event (Oswald and Carey, 2016). These patterns are likely the result of oxidation of accumulated sulfides to sulfates when wetland soils are exposed to air and then reflooded (Coleman Wasik et al., 2015).

\subsubsection{Small artificial wetlands as sources of methylmercury}

Artificial wetlands is a collective term, including a multiplicity of different wetland types created for purposes ranging from replacement of damaged or destroyed natural wetlands, to the specialized treatment of particular wastewaters. In my thesis, I focused on stormwater and habitat wetlands, which are an increasingly popular method of reducing pollutant concentrations and flooding risk while providing habitat and aesthetic benefits and maintaining a functional hydrological cycle. These small, pondlike artificial wetlands accumulate MeHg (Chavan et al., 2007; Gustin et al., 2006; Rumbold and Fink, 2006; Sinclair et al., 2012; Stamenkovic et al., 2005), but there has been relatively little investment in understanding the MeHg biogeochemistry 
of these systems. Much of the work on this subject has been carried out in arid subtropical desert climates (Stamenkovic et al. 2005; Gustin et al. 2006; Chavan et al. 2007) or the humid subtropics (Rumbold and Fink 2006). Only one study of five small, functional artificial wetlands in a temperate climate has been carried out, which observed $\mathrm{Hg}$ methylation rates that varied over an order of magnitude and, in one young site, accumulation of $\mathrm{MeHg}$ to levels which may represent a hazard to wildlife (Sinclair et al. 2012). The Hg methylation potential of temperate stormwater wetlands has never been assessed.

The construction techniques and maintenance activities employed during the creation of an artificial wetland have important implications for $\mathrm{MeHg}$ biogeochemistry. In Ontario, both stormwater and habitat wetlands are constructed by excavation of a basin or construction of earth berms. Stormwater ponds are usually simple in shape with a smooth, regular basin, but the sediment topography of habitat wetlands may be complex as the construction team may have excavated multiple pits (borrow pits) in search of suitable soil for berming. In both methods, topsoil is removed and vegetation is destroyed. During the excavation process, soils are compacted, smoothed, and homogenized, which alters their porosity, hydraulic conductivity, and the availability of microtopographic sites (Bruland and Richardson, 2006; Stolt et al., 2000), which may reduce plant and microbial diversity (Stottmeister et al., 2003). Clay liners are installed in stormwater wetland basins, which isolates the wetland from the groundwater; habitat wetlands may or may not feature a liner, particularly if they are thoughtfully sited to take advantage of the natural hydrology (Bob Clay, personal communication). After construction, organic matter is sometimes added to improve the functioning of the wetland (Bruland et al., 2009), but artificial wetlands under 10 years old are generally poor in organic matter in comparison to natural wetlands, as well as having higher bulk densities and more homogenous surfaces (Campbell et al., 2002; Stolt et al., 2000; Wolf et al., 2011). This alteration in sediment structure results in vegetation and microbial community structures that differ from natural wetlands (Campbell et al., 2002; Peralta et al., 2010; Stottmeister et al., 2003; Weaver et al., 2012), as well as Hg sorption dynamics (Meng et al., 2016). Plants may be installed during construction, or colonies the site through natural dispersal (Ontario Ministry of Environment, 2003). 
Once established, a constructed wetland functions essentially by slowing water flow, allowing suspended matter and particulate pollutants to settle out of solution and biotic processes to degrade many contaminants. Artificial wetlands usually receive more polluted runoff, in more intense pulses, and at higher velocities, than natural wetlands, and are subject to frequent cycles of wetting and drying (Cole and Brooks, 2000; Kadlec and Wallace 2009). In urban areas, runoff is elevated in $\mathrm{Hg}$ (Eckley and Branfireun, 2008; Lawson et al., 2001) a large proportion of which is sorbed to very small particles (Eckley and Branfireun, 2008) and thus may be more bioavailable (Hsu-Kim et al., 2013). As a wetland ages, sediment and its associated contaminants accumulate, until the wetland must be cleaned in order to maintain its hydrological and pollution control functions. Dredging and disposal of sediment is thus an important part of stormwater wetland maintenance (Drake and Guo, 2008). Dredging is usually carried out through water diversion, dry sediment removal, and reflooding. The process takes several weeks and destroys most of the existing vegetation (David Kenth, personal communication). Sedimentation is a natural process and of less concern in created habitat wetlands, which are usually not dredged (Bob Clay, personal communication). A constructed stormwater wetland therefore has a lifecycle of 5-15 years, beginning with construction, after which the wetland matures, and is finally dredged. 


\subsection{References}

Acha, D., Iniguez, V., Roulet, M., Guimaraes, J.R.D., Luna, R., Alanoca, L., Sanchez, S., 2005. Sulfatereducing bacteria in floating macrophyte rhizospheres from an Amazonian floodplain lake in Bolivia and their association with Hg methylation. Appl. Environ. Microbiol. 71, 7531-7535. doi:10.1128/AEM.71.11.7531-7535.2005

Amirbahman, A., Reid, A., Haines, T., Kahl, S., Arnold, C. 2002. Association of methylmercury with dissolved humic acids. Envir. Sci. Technol. 36, 690-695.

Amos, H.M., Jacob, D.J., Streets, D.G., Sunderland, E.M., 2013. Legacy impacts of all-time anthropogenic emissions on the global mercury cycle: global impacts of legacy mercury. Glob. Biogeochem. Cycles 27, 410-421. doi:10.1002/gbc.20040

Andersen, R., Chapman, S.J., Artz, R.R.E., 2013. Microbial communities in natural and disturbed peatlands: A review. Soil Biol. Biochem. 57, 979-994. doi:10.1016/j.soilbio.2012.10.003

Bachand, P.A.M., Bachand, S.M., Fleck, J.A., Alpers, C.N., Stephenson, M., Windham-Myers, L., 2014. Methylmercury production in and export from agricultural wetlands in California, USA: The need to account for physical transport processes into and out of the root zone. Sci. Total Environ. 472, 957-970. doi:10.1016/j.scitotenv.2013.11.086

Bae, H.-S., Dierberg, F.E., Ogram, A., 2014. Syntrophs dominate sequences associated with the mercury methylation-related gene hgcA in the water conservation areas of the Florida Everglades. Appl. Environ. Microbiol. 80, 6517-6526. doi:10.1128/AEM.01666-14

Barkay, T., Gillman, M., Turner, R.R. 1997. Effects of dissolved organic carbon and salinity on bioavailability of mercury. Appl. Environ. Microbio. 63, 4267-4271.

Barkay, T., Miller, S.M., Summers, A.O., 2003. Bacterial mercury resistance from atoms to ecosystems. FEMS Microbiol. Rev. 27, 355-384. doi:10.1016/S0168-6445(03)00046-9

Benoit, J. M., Gilmour, C. C., Mason, R. P., Heyes, A. 1999a. Sulfide controls on mercury speciation and bioavailability to methylating bacteria in sediment pore waters. Environ. Sci. Technol. 33, 951957.

Benoit, J. M., Gilmour, C.C., Heyes, A., Mason, R.P., Miller, C.L. 2003. Geochemical and biological controls over methylmercury production and degradation in aquatic ecosystems, in: Cai, Y., Braids, O.C. (Eds.) Biogeochemistry of Environmentally Important Trace Elements. Amercian Chemical Society, San Diego, pp. 262-297.

Branfireun, B., Heyes, A., Roulet, N. 1996. The hydrology and methylmercury dynamics of a Precambrian Shield headwater peatland. Water Resour. Res. 32, 1785-1794. 
Branfireun, B., Roulet, N., Kelly, C., Rudd, J. 1999. In situ sulphate stimulation of mercury methylation in a boreal peatland: toward a link between acid rain and methylmercury contamination in remote environments. Global Biogeochem. Cycles 13, 743-750.

Bridou, R., Monperrus, M., Gonzalez, P.R., Guyoneaud, R., Amouroux, D., 2011. Simultaneous determination of mercury methylation and demethylation capacities of various sulfate-reducing bacteria using species-specific isotopic tracers. Environ. Toxicol. Chem. 30, 337-344. doi:10.1002/etc.395

Brix, H. 1994. Functions of macrophytes in constructed wetlands. Wat. Sci. Technol. 29, 71-78.

Brix, H., 1997. Do macrophytes play a role in constructed treatment wetlands? Water Sci. Technol. 35, 11-17. doi:10.1016/S0273-1223(97)00047-4

Bruland, G.L., Richardson, C.J., 2006. Comparison of soil organic matter in created, restored and paired natural wetlands in North Carolina. Wetl. Ecol. Manag. 14, 245-251. doi:10.1007/s11273-0051116-z

Bruland, G.L., Richardson, C.J., Daniels, W.L., 2009. Microbial and geochemical responses to organic matter amendments in a created wetland. Wetlands 29, 1153-1165. doi:10.1672/08-201.1

Brune, A., Frenzel, P., Cyprionka, H. 2000. Life at the oxic-anoxic interface: microbial activities and adaptations. FEMS Microbiol. Rev. 24 671-710.

Burgess, N.M., Meyer, M.W., 2007. Methylmercury exposure associated with reduced productivity in common loons. Ecotoxicology 17, 83-91. doi:10.1007/s10646-007-0167-8

Campbell, D.A., Cole, C.A., Brooks, R.P., 2002. A comparison of created and natural wetlands in Pennsylvania, USA. Wetl. Ecol. Manag. 10, 41-49.

Canário, J., Caetano, M., Vale, C., Cesário, R., 2007. Evidence for elevated production of methylmercury in salt marshes. Environ. Sci. Technol. 41, 7376-7382. doi:10.1021/es071078j

Chavan, P.V., Dennett, K.E., Marchand, E.A., Gustin, M.S., 2007. Evaluation of small-scale constructed wetland for water quality and $\mathrm{Hg}$ transformation. J. Hazard. Mater. 149, 543-547.

Christensen, G.A., Wymore, A.M., King, A.J., Podar, M., Hurt, R.A., Santillan, E.U., Soren, A., Brandt, C.C., Brown, S.D., Palumbo, A.V., Wall, J.D., Gilmour, C.C., Elias, D.A., 2016. Development and validation of broad-range qualitative and clade-specific quantitative molecular probes for assessing mercury methylation in the environment. Appl. Environ. Microbiol. AEM.01271-16. doi:10.1128/AEM.01271-16

Chumchal, M.M., Drenner, R.W., 2015. An environmental problem hidden in plain sight? Small humanmade ponds, emergent insects, and mercury contamination of biota in the Great Plains: An environmental problem hidden in plain sight. Environ. Toxicol. Chem. 34, 1197-1205. doi:10.1002/etc. 2954 
Cohen, M., Artz, R., Draxler, R., Miller, P., Poissant, L., Niemi, D., Ratté, D., Deslauriers, M., Duval, R., Laurin, R., Slotnick, J., Nettesheim, T., McDonald, J., 2004. Modeling the atmospheric transport and deposition of mercury to the Great Lakes. Environ. Res. 95, 247-265. doi:10.1016/j.envres.2003.11.007

Cole, C.A., Brooks, R.P., 2000. A comparison of the hydrologic characteristics of natural and created mainstem floodplain wetlands in Pennsylvania. Ecol. Eng. 14, 221-231.

Coleman Wasik, J.K., Engstrom, D.R., Mitchell, C.P.J., Swain, E.B., Monson, B.A., Balogh, S.J., Jeremiason, J.D., Branfireun, B.A., Kolka, R.K., Almendinger, J.E., 2015. The effects of hydrologic fluctuation and sulfate regeneration on mercury cycling in an experimental peatland: Drought increases mercury in peatlands. J. Geophys. Res. Biogeosciences 120, 1697-1715. doi:10.1002/2015JG002993

Coleman Wasik, J.K., Mitchell, C.P.J., Engstrom, D.R., Swain, E.B., Monson, B.A., Balogh, S.J., Jeremiason, J.D., Branfireun, B.A., Eggert, S.L., Kolka, R.K., Almendinger, J.E., 2012. Methylmercury declines in a boreal peatland when experimental sulfate deposition decreases. Environ. Sci. Technol. 46, 6663-6671. doi:10.1021/es300865f

Compeau, G., Bartha, R., 1983. Effects of sea salt anions on the formation and stability of methylmercury. Bull. Environ. Contam. Toxicol. 31, 486-493.

Compeau, G.C., Bartha, R., 1985. Sulfate-reducing bacteria: principal methylators of mercury in anoxic estuarine sediment. Appl. Environ. Microbiol. 50, 498-502.

Conrad, R., 1996. Soil microorganisms as controllers of atmospheric trace gases $\left(\mathrm{H}_{2}, \mathrm{CO}, \mathrm{CH}_{4}, \mathrm{OCS}\right.$, $\mathrm{N}_{2} \mathrm{O}$, and NO). Microbiol. Rev. 60, 609-640.

Corriera, R.R.S., Miranda, M. R., Guimaraes, J.R.D. 2012b. Mercury methylation and the microbial consortium in periphyton of tropical macrophytes: effect of different inhibitors. Environ. Res. $112,86-91$.

Cosio, C., Flück, R., Regier, N., Slaveykova, V.I., 2014. Effects of macrophytes on the fate of mercury in aquatic systems: $\mathrm{Hg}$ and macrophytes. Environ. Toxicol. Chem. 33, 1225-1237. doi:10.1002/etc. 2499

Davis, J.A., Looker, R.E., Yee, D., Marvin-Di Pasquale, M., Grenier, J.L., Austin, C.M., McKee, L.J., Greenfield, B.K., Brodberg, R., Blum, J.D., 2012. Reducing methylmercury accumulation in the food webs of San Francisco Bay and its local watersheds. Environ. Res. 119, 3-26. doi:10.1016/j.envres.2012.10.002

deBruyn, A. M.H., Gobas, F.A.P.C. 2006. A bioenergetic biomagnification model for the animal kingdom. Environ. Sci. Tech. 40 1581-1557. 
de Wit, H.A., Kainz, M.J., Lindholm, M., 2012. Methylmercury bioaccumulation in invertebrates of boreal streams in Norway: Effects of aqueous methylmercury and diet retention. Environ. Pollut. 164, 235-241. doi:10.1016/j.envpol.2012.01.041

Desrosiers, M., Planas, D., Mucci, A. 2006. Total mercury and methylmercury accumulation in periphyton of Boreal Shield Lakes: Influence of watershed physiographic characteristics. Sci. Total Environ. 355, 247-258.

Dittman, J.A., Shanley, J.B., Driscoll, C.T., Aiken, G.R., Chalmers, A.T., Towse, J.E., Selvendiran, P., 2010. Mercury dynamics in relation to dissolved organic carbon concentration and quality during high flow events in three northeastern U.S. streams: Mercury and doc dynamics during high flow events. Water Resour. Res. 46, n/a-n/a. doi:10.1029/2009WR008351

Doyle, M.O., Otte, M.L., 1997. Organism-induced accumulation of iron, zinc and arsenic in wetland soils. Environ. Pollut. 96, 1-11.

Drake, J., Guo, Y. 2008. Maintenance of wet stormwater ponds in Ontario. Can. Wat. Res. J. 33, 351-368.

Driscoll, C.T., Yan, C., Schofield, C.L., Munson, R., Holsapple, J. 1994. The role of dissolved organic carbon in the chemistry and bioavailability of mercury in remote Adirondack lakes. Water Air Soil Pollut. 80, 499-508.

Driscoll, C.T., Mason, R.P., Chan, H.M., Jacob, D.J., Pirrone, N., 2013. Mercury as a global pollutant: Sources, pathways, and effects. Environ. Sci. Technol. 47, 4967-4983. doi:10.1021/es305071v

Drott, A., Lambertsson, L., Björn, E., Skyllberg, U., 2008. Do potential methylation rates reflect accumulated methyl mercury in contaminated sediments? Environ. Sci. Technol. 42, 153-158. doi:10.1021/es0715851

Eagles-Smith, C.A., Wiener, J.G., Eckley, C.S., Willacker, J.J., Evers, D.C., Marvin-DiPasquale, M., Obrist, D., Fleck, J.A., Aiken, G.R., Lepak, J.M., Jackson, A.K., Webster, J.P., Stewart, A.R., Davis, J.A., Alpers, C.N., Ackerman, J.T., 2016. Mercury in western North America: A synthesis of environmental contamination, fluxes, bioaccumulation, and risk to fish and wildlife. Sci. Total Environ. doi:10.1016/j.scitotenv.2016.05.094

Eckley, C.S., Branfireun, B., 2008. Mercury mobilization in urban stormwater runoff. Sci. Total Environ. 403, 164-177. doi:10.1016/j.scitotenv.2008.05.021

Eckley, C.S., Luxton, T.P., McKernan, J.L., Goetz, J., Goulet, J., 2015. Influence of reservoir water level fluctuations on sediment methylmercury concentrations downstream of the historical Black Butte mercury mine, OR. Appl. Geochem. 61, 284-293. doi:10.1016/j.apgeochem.2015.06.011

Edmonds, S.T., O’Driscoll, N.J., Hillier, N.K., Atwood, J.L., Evers, D.C., 2012. Factors regulating the bioavailability of methylmercury to breeding rusty blackbirds in northeastern wetlands. Environ. Pollut. 171, 148-154. doi:10.1016/j.envpol.2012.07.044 
Engstrom, D.R., 2007. Fish respond when the mercury rises. Proc. Natl. Acad. Sci. 104, 16394-16395.

Faulwetter, J.L., Burr, M.D., Parker, A.E., Stein, O.R., Camper, A.K., 2012. Influence of season and plant species on the abundance and diversity of sulfate reducing bacteria and ammonia oxidizing bacteria in constructed wetland microcosms. Microb. Ecol. 1-17.

Feng, S., Ai, Z., Zheng, S., Gu, B., Li, Y., 2014. Effects of dryout and inflow water quality on mercury methylation in a constructed wetland. Water. Air. Soil Pollut. 225. doi:10.1007/s11270-014-19296

Fitzgerald, W.F., Engstrom, D.R., Mason, R.P., Nater, E.A., 1998. The case for atmospheric mercury contamination in remote areas. Environ. Sci. Technol. 32, 1-7.

Fleming, E.J., Mack, E.E., Green, P.G., Nelson, D.C., 2006. Mercury methylation from unexpected sources: Molybdate-inhibited freshwater sediments and an iron-reducing bacterium. Appl. Environ. Microbiol. 72, 457-464. doi:10.1128/AEM.72.1.457-464.2006

Gentès, S., Monperrus, M., Legeay, A., Maury-Brachet, R., Davail, S., André, J.-M., Guyoneaud, R., 2013. Incidence of invasive macrophytes on methylmercury budget in temperate lakes: Central role of bacterial periphytic communities. Environ. Pollut. 172, 116-123. doi:10.1016/j.envpol.2012.08.004

Gilmour, C.C., Elias, D.A., Kucken, A.M., Brown, S.D., Palumbo, A.V., Schadt, C.W., Wall, J.D., 2011. Sulfate-reducing bacterium desulfovibrio desulfuricans nd132 as a model for understanding bacterial mercury methylation. Appl. Environ. Microbiol. 77, 3938-3951. doi:10.1128/AEM.02993-10

Gilmour, C.C., Henry, E.A., Mitchell, R., 1992. Sulfate stimulation of mercury methylation in freshwater sediments. Environ. Sci. Technol. 26, 2281-2287.

Gilmour, C.C., Krabbenhoft, D., Orem, W., Aiken, G., Roden, E., 2004. Appendix 2B-1: influence of drying and rewetting on mercury and sulfur cycling in Everglades and STA soils. 2004 Everglades Consolodated Rep.

Gilmour, C.C., Podar, M., Bullock, A.L., Graham, A.M., Brown, S.D., Somenahally, A.C., Johs, A., Hurt, R.A., Bailey, K.L., Elias, D.A., 2013. Mercury methylation by novel microorganisms from new environments. Environ. Sci. Technol. 47, 11810-11820. doi:10.1021/es403075t

Gionfriddo, C.M., Tate, M.T., Wick, R.R., Schultz, M.B., Zemla, A., Thelen, M.P., Schofield, R., Krabbenhoft, D.P., Holt, K.E., Moreau, J.W., 2016. Microbial mercury methylation in Antarctic sea ice. Nat. Microbiol. 1, 16127. doi:10.1038/nmicrobiol.2016.127

Goulet, R.R., Holmes, J., Page, B., Poissant, L., Siciliano, S.D., Lean, D.R.S., Wang, F., Amyot, M., Tessier, A., 2007. Mercury transformations and fluxes in sediments of a riverine wetland. Geochim. Cosmochim. Acta 71, 3393-3406. doi:10.1016/j.gca.2007.04.032 
Graham, A.M., Aiken, G.R., Gilmour, C.C., 2012a. Dissolved organic matter enhances microbial mercury methylation under sulfidic conditions. Environ. Sci. Technol. 46, 2715-2723. doi:10.1021/es203658f

Graham, A.M., Bullock, A.L., Maizel, A.C., Elias, D.A., Gilmour, C.C., 2012b. Detailed Assessment of the kinetics of $\mathrm{Hg}$-cell association, $\mathrm{Hg}$ methylation, and methylmercury degradation in several Desulfovibrio species. Appl. Environ. Microbiol. 78, 7337-7346. doi:10.1128/AEM.01792-12

Grigal, D.F., 2002. Inputs and outputs of mercury from terrestrial watersheds: A review. Environ. Rev. 10, 1-39. doi:10.1139/a01-013

Guimarães, J.R.D., Mauro, J.B.N., Meili, M., Sundbom, M., Haglund, A.L., Coelho-Souza, S.A., Hylander, L.D., 2006. Simultaneous radioassays of bacterial production and mercury methylation in the periphyton of a tropical and a temperate wetland. J. Environ. Manage. 81, 95-100. doi:10.1016/j.jenvman.2005.09.023

Gustin, M.S., Chavan, P.V., Dennett, K.E., Donaldson, S., Marchand, E., Fernanadez, G., 2006. Use of constructed wetlands with four different experimental designs to assess the potential for methyl and total Hg outputs. Appl. Geochem. 21, 2023-2035.

Hall, B.D., Aiken, G.R., Krabbenhoft, D.P., Marvin-DiPasquale, M., Swarzenski, C.M., 2008. Wetlands as principal zones of methylmercury production in southern Louisiana and the Gulf of Mexico region. Environ. Pollut. 154, 124-134. doi:10.1016/j.envpol.2007.12.017

Hall, B.D., Bodaly, R.A., Fudge, R.J.P., Rudd, J.W.M., Rosenberg, D.M., 1997. Food as the dominant pathway of methylmercury uptake by fish. Water. Air. Soil Pollut. 100, 13-24.

Hall, B.D., Louis, V.L.S., Rolfhus, K.R., Bodaly, R.A., Beaty, K.G., Paterson, M.J., Cherewyk, K.A.P., 2005. Impacts of reservoir creation on the biogeochemical cycling of methyl mercury and total mercury in boreal upland forests. Ecosystems 8, 248-266. doi:10.1007/s10021-003-0094-3

Hamelin, S., Amyot, M., Barkay, T., Wang, Y., Planas, D., 2011. Methanogens: Principal methylators of mercury in lake periphyton. Environ. Sci. Technol. 45, 7693-7700. doi:10.1021/es2010072

Hammerschmidt, C.R., Fitzgerald, W.F., Balcom, P.H., Visscher, P.T., 2008. Organic matter and sulfide inhibit methylmercury production in sediments of New York/New Jersey Harbor. Mar. Chem. 109, 165-182. doi:10.1016/j.marchem.2008.01.007

Harmon, S.M., King, J.K., Gladden, J.B., Chandler, G.T., Newman, L.A., 2004. Methylmercury formation in a wetland mesocosm amended with sulfate. Environ. Sci. Technol. 38, 650-656. doi:10.1021/es030513g

Harris, R.C., Rudd, J.W.M., Amyot, M., Babiarz, C.L., Beaty, K.G., Blanchfield, P.J., Bodaly, R.A., Branfireun, B.A., Gilmour, C.C., Graydon, J.A., Heyes, A., Hintelmann, H., Hurley, J.P., Kelly, C.A., Krabbenhoft, D.P., Lindberg, S.E., Mason, R.P., Paterson, M.J., Podemski, C.L., Robinson, 
A., Sandilands, K.A., Southworth, G.R., St. Louis, V.L., Tate, M.T., 2007. Whole-ecosystem study shows rapid fish-mercury response to changes in mercury deposition. Proc. Natl. Acad. Sci. 104, 16586-16591. doi:10.1073/pnas.0704186104

Haynes, K.M., Mitchell, C.P.J., 2012. Inter-annual and spatial variability in hillslope runoff and mercury flux during spring snowmelt. J. Environ. Monit. 14, 2083. doi:10.1039/c2em30267e

He, T., Lu, J., Yang, F., Feng, X., 2007. Horizontal and vertical variability of mercury species in pore water and sediments in small lakes in Ontario. Sci. Total Environ. 386, 53-64. doi:10.1016/j.scitotenv.2007.07.022

Hintelmann, H., Evans, R.D., 1997. Application of stable isotopes in environmental tracer studies Measurement of monomethylmercury $\left(\mathrm{CH}_{3} \mathrm{Hg}^{+}\right)$by isotope dilution ICP-MS and detection of species transformation. Fresenius J. Anal. Chem. 358, 378-385. doi:10.1007/s002160050433

Hintelmann, H., Evans, R.D., Villeneuve, J.Y., 1995. Measurement of mercury methylation in sediments by using enriched stable mercury isotopes combined with methylmercury determination by gas chromatography-inductively coupled plasma mass spectrometry. J. Anal. At. Spectrom. 10, 619624.

Hintelmann, H., Harris, R., Heyes, A., Hurley, J.P., Kelly, C.A., Krabbenhoft, D.P., Lindberg, S., Rudd, J.W.M., Scott, K.J., St.Louis, V.L., 2002. Reactivity and mobility of new and old mercury deposition in a boreal forest ecosystem during the first year of the METAALICUS Study. Environ. Sci. Technol. 36, 5034-5040. doi:10.1021/es025572t

Hintelmann, H., Keppel-Jones, K., Evans, R.D., 2000. Constants of mercury methylation and demethylation rates in sediments and comparison of tracer and ambient mercury availability. Environ. Toxicol. Chem. 19, 2204-2211.

Hoggarth, C.G.J., Hall, B.D., Mitchell, C.P.J., 2015. Mercury methylation in high and low-sulphate impacted wetland ponds within the prairie pothole region of North America. Environ. Pollut. 205, 269-277. doi:10.1016/j.envpol.2015.05.046

Holloway, J.M., Goldhaber, M.B., Scow, K.M., Drenovsky, R.E., 2009. Spatial and seasonal variations in mercury methylation and microbial community structure in a historic mercury mining area, Yolo County, California. Chem. Geol. 267, 85-95. doi:10.1016/j.chemgeo.2009.03.031

Holmes, J., Lean, D., 2006. Factors that influence methylmercury flux rates from wetland sediments. Sci. Total Environ. 368, 306-319. doi:10.1016/j.scitotenv.2005.11.027

Horvat, M., Nolde, N., Fajon, V., Jereb, V., Logar, M., Lojen, S., Jacimovic, R., Falnoga, I., Liya, Q., Faganeli, J., others, 2003. Total mercury, methylmercury and selenium in mercury polluted areas in the province Guizhou, China. Sci. Total Environ. 304, 231-256. 
Hsu-Kim, H., Kucharzyk, K.H., Zhang, T., Deshusses, M.A., 2013. Mechanisms regulating mercury bioavailability for methylating microorganisms in the aquatic environment: A critical review. Environ. Sci. Technol. 130227163055006. doi:10.1021/es304370g

Jacob, D.L., Otte, M.L., 2003. Conflicting processes in the wetland plant rhizosphere: Metal retention or mobilization? Water Air Soil Pollut. Focus 3, 91-104.

Jaffe, D., Strode, S., 2008. Sources, fate and transport of atmospheric mercury from Asia. Environ. Chem. 5, 121. doi:10.1071/EN08010

Jensen, S., Jernelöv, A., 1969. Biological methylation of mercury in aquatic Organisms. Nature 223, $753-$ 754. doi:10.1038/223753a0

Jeremiason, J.D., Engstrom, D.R., Swain, E.B., Nater, E.A., Johnson, B.M., Almendinger, J.E., Monson, B.A., Kolka, R.K., 2006. Sulfate addition increases methylmercury production in an experimental wetland. Environ. Sci. Technol. 40, 3800-3806. doi:10.1021/es0524144

Jorgenesen, B.B. 1977. The sulfur cycle of a coastal marine sediment (Limfjorden, Denmark). Limnol. Oceanogr. 22 814-832.

Junk, W.J., Bayley, P.B., Sparks, R.E. 1989. The flood pulse concept in river-floodplain systems. In: D.P. Dodge (Ed.) Proceedings of the International Large River Symposium, Can. J. Fish. Aquat. Sci. $106,11-127$.

Kadlec, R.H., Wallace, S. 2009. Treatment Wetlands, second ed. CRC Press, Taylor \& Francis Publishing, New York.

Kahl, J.S., Stoddard, J.L., Haeuber, R., Paulsen, S.G., Birnbaum, R., Deviney, F.A., Webb, J.R., DeWalle, D.R., Sharpe, W., Driscoll, C.T., others, 2004. Peer reviewed: have us surface waters responded to the 1990 Clean Air Act Amendments? Environ. Sci. Technol. 38, 484A-490A.

Karagas, M.R., Choi, A.L., Oken, E., Horvat, M., Schoeny, R., Kamai, E., Cowell, W., Grandjean, P., Korrick, S., 2012. Evidence on the human health effects of low-level methylmercury exposure. Environ. Health Perspect. 120, 799-806. doi:10.1289/ehp.1104494

Karimi, R., Chen, C.Y., Pickhardt, P.C., Fisher, N.S., Folt, C.L., 2007. Stoichiometric controls of mercury dilution by growth. Proc. Natl. Acad. Sci. 104, 7477-7482.

Kerin, E.J., Gilmour, C.C., Roden, E., Suzuki, M.T., Coates, J.D., Mason, R.P., 2006. Mercury methylation by dissimilatory iron-reducing bacteria. Appl. Environ. Microbiol. 72, 7919-7921. doi:10.1128/AEM.01602-06

Khush, G.S., 2005. What it will take to feed 5.0 billion rice consumers in 2030. Plant Mol. Biol. 59, 1-6. doi:10.1007/s11103-005-2159-5

King, J.K., Harmon, S.M., Fu, T.T., Gladden, J.B., 2002. Mercury removal, methylmercury formation, and sulfate-reducing bacteria profiles in wetland mesocosms. Chemosphere 46, 859-870. 
King, J.K., Kostka, J.E., Frischer, M.E., Saunders, F.M., 2000. Sulfate-Reducing Bacteria Methylate Mercury at Variable Rates in Pure Culture and in Marine Sediments. Appl. Environ. Microbiol. $66,2430-2437$.

Lawson, N.M., Mason, R.P., Laporte, J.-M., 2001. The fate and transport of mercury, methylmercury, and other trace metals in Chesapeake Bay tributaries. Water Res. 35, 501-515.

Li, B., Shi, J.B., Wang, X., Meng, M., Huang, L., Qi, X.L., He, B., Ye, Z.H., 2013. Variations and constancy of mercury and methylmercury accumulation in rice grown at contaminated paddy field sites in three Provinces of China. Environ. Pollut. 181, 91-97. doi:10.1016/j.envpol.2013.06.021

Li, L., Wang, F., Meng, B., Lemes, M., Feng, X., Jiang, G., 2010. Speciation of methylmercury in rice grown from a mercury mining area. Environ. Pollut. 158, 3103-3107. doi:10.1016/j.envpol.2010.06.028

Li, P., Feng, X., Chan, H.-M., Zhang, X., Du, B., 2015. Human body burden and dietary methylmercury intake: The relationship in a rice-consuming population. Environ. Sci. Technol. 49, 9682-9689. doi:10.1021/acs.est.5b00195

Li, P., Feng, X., Qiu, G., 2010. Methylmercury exposure and health effects from rice and fish consumption: A review. Int. J. Environ. Res. Public. Health 7, 2666-2691. doi:10.3390/ijerph7062666

Lin, C.-C., Yee, N., Barkay, T., 2012. Microbial transformations in the mercury cycle. Environ. Chem. Toxicol. Mercury 155-191.

Lindberg, S., Dong, W., Chanton, J., Qualls, R., Meyers, T., 2005. A mechanism for bimodal emission of gaseous mercury from aquatic macrophytes. Atmos. Environ. 39, 1289-1301. doi:10.1016/j.atmosenv.2004.11.006

Liu, G., Li, Y., Cai, Y., 2012. Adsorption of mercury on solids in the aquatic environment, in: Liu, G., Cai, Y., O’Driscoll, N. (eds.), Environmental Chemistry and Toxicology of Mercury, first ed. John Wiley \& Sons, Inc, Hoboken, New Jersey.

Liu, Y.-R., Yu, R.-Q., Zheng, Y.-M., He, J.-Z., 2014. Analysis of the microbial community structure by monitoring an $\mathrm{Hg}$ methylation gene (hgcA) in paddy soils along an $\mathrm{Hg}$ gradient. Appl. Environ. Microbiol. 80, 2874-2879. doi:10.1128/AEM.04225-13

Liu, Y.-R., Zheng, Y.-M., Zhang, L.-M., He, J.-Z., 2013. Linkage between community diversity of sulfate-reducing microorganisms and methylmercury concentration in paddy soil. Environ. Sci. Pollut. Res. 21, 1339-1348. doi:10.1007/s11356-013-1973-6 
Mahaffey, K.R., Clickner, R.P., Bodurow, C.C., 2003. Blood organic mercury and dietary mercury intake: National Health and Nutrition Examination Survey, 1999 and 2000. Environ. Health Perspect. 112, 562-570. doi:10.1289/ehp.6587

Mailman, M., Stepnuk, L., Cicek, N., Bodaly, R.A. (Drew), 2006. Strategies to lower methyl mercury concentrations in hydroelectric reservoirs and lakes: A review. Sci. Total Environ. 368, 224-235. doi:10.1016/j.scitotenv.2005.09.041

Mao, Y., Li, Y., Richards, J., Cai, Y., 2013. Investigating uptake and translocation of mercury species by sawgrass (Cladium jamaicense) using a stable isotope tracer technique. Environ. Sci. Technol. 47, 9678-9684. doi:10.1021/es400546s

Marschner, H. 1995. Mineral Nutrition of Higher Plants, second ec. Academic Press, London.

Marvin-DiPasquale, M., Agee, J., McGowan, C., Oremland, R.S., Thomas, M., Krabbenhoft, D., Gilmour, C.C., 2000. Methyl-mercury degradation pathways: A comparison among three mercury-impacted ecosystems. Environ. Sci. Technol. 34, 4908-4916. doi:10.1021/es0013125

Mason, R.P., Sheu, G.R. 2002. Role of the ocean in the global mercury cycle. Glob. Biogeochem. Cycles 16, 1093-1098.

Mathews, T., Fisher, N.S., 2008. Evaluating the trophic transfer of cadmium, polonium, and methylmercury in an estuarine food chain. Environ. Toxicol. Chem. 27, 1093-1101.

McCord, S.A., Heim, W.A., 2015. Identification and prioritization of management practices to reduce methylmercury exports from wetlands and irrigated agricultural lands. Environ. Manage. 55, 725-740. doi:10.1007/s00267-014-0425-5

Mendelssohn, I.A., Kleiss, B.A., Wakeley, J.S., 1995. Factors controlling the formation of oxidized root channels: a review. Wetlands 15, 37-46.

Meng, B., Feng, X., Qiu, G., Anderson, C.W.N., Wang, J., Zhao, L., 2014. Localization and speciation of mercury in brown rice with implications for Pan-Asian public health. Environ. Sci. Technol. 48, 7974-7981. doi:10.1021/es502000d

Meng, B., Feng, X., Qiu, G., Li, Z., Yao, H., Shang, L., Yan, H., 2016. The impacts of organic matter on the distribution and methylation of mercury in a hydroelectric reservoir in Wujiang River, Southwest China: The influence of organic matter on mercury cycling. Environ. Toxicol. Chem. 35, 191-199. doi:10.1002/etc.3181

Meng, B., Feng, X., Qiu, G., Liang, P., Li, P., Chen, C., Shang, L., 2011. The process of methylmercury accumulation in rice (Oryza sativa L.). Environ. Sci. Technol. 45, 2711-2717. doi:10.1021/es103384v 
Meng, M., Li, B., Shao, J., Wang, T., He, B., Shi, J., Ye, Z., Jiang, G., 2014. Accumulation of total mercury and methylmercury in rice plants collected from different mining areas in China. Environ. Pollut. 184, 179-186. doi:10.1016/j.envpol.2013.08.030

Mergler, D., Anderson, H.A., Chan, L.H.M., Mahaffey, K.R., Murray, M., Sakamoto, M., Stern, A.H., 2007. Methylmercury exposure and health effects in humans: A worldwide concern. AMBIO J. Hum. Environ. 36, 3-11. doi:10.1579/0044-7447(2007)36[3:MEAHEI]2.0.CO;2

Mitchell, C.P.J., Gilmour, C.C., 2008. Methylmercury production in a Chesapeake Bay salt marsh. J. Geophys. Res. 113, G00C04.

Mitsch, W.J., Gosselink, J.G. 2007. Wetlands, fourth ed. John Wiley \& Sons. Inc, Hoboken, New Jersey. Mosher, J., Vishnivetskaya, T., Elias, D., Podar, M., Brooks, S., Brown, S., Brandt, C., Palumbo, A., 2012. Characterization of the Deltaproteobacteria in contaminated and uncontaminated stream sediments and identification of potential mercury methylators. Aquat. Microb. Ecol. 66, 271-282. doi:10.3354/ame01563

Munthe, J., Bodaly, R.A. (Drew), Branfireun, B.A., Driscoll, C.T., Gilmour, C.C., Harris, R., Horvat, M., Lucotte, M., Malm, O., 2007. Recovery of mercury-contaminated fisheries. AMBIO J. Hum. Environ. 36, 33-44. doi:10.1579/0044-7447(2007)36[33:ROMF]2.0.CO;2

National Atmospheric Deposition Network, 2011. Mercury deposition network annual map 2011. http://nadp.sws.uiuc.edu./MDN/maps.aspx (accessed 1.04.13).

Obrist, D., Johnson, D.W., Lindberg, S.E., Luo, Y., Hararuk, O., Bracho, R., Battles, J.J., Dail, D.B., Edmonds, R.L., Monson, R.K., Ollinger, S.V., Pallardy, S.G., Pregitzer, K.S., Todd, D.E., 2011. Mercury distribution across 14 U.S. forests. Part I: Spatial patterns of concentrations in biomass, litter, and soils. Environ. Sci. Technol. 45, 3974-3981. doi:10.1021/es104384m

O’Driscoll, N.J., Canário, J., Crowell, N., Webster, T., 2011. Mercury speciation and distribution in coastal wetlands and tidal mudflats: Relationships with sulphur speciation and organic carbon. Water. Air. Soil Pollut. 220, 313-326. doi:10.1007/s11270-011-0756-2

Olsen, G. J., Woese, C. R. 1997. Archaeal genomics: an overview minireview. Cell 89, 991-994.

Ontario Ministry of the Environment, 2003. Stormwater management planning and design manual. MOE, Toronto, Ontario.

Oswald, C.J., Carey, S.K., 2016. Total and methyl mercury concentrations in sediment and water of a constructed wetland in the Athabasca Oil Sands Region. Environ. Pollut. 213, 628-637. doi:10.1016/j.envpol.2016.03.002

Pacyna, E.G., Pacyna, J.M., Steenhuisen, F., Wilson, S., 2006. Global anthropogenic mercury emission inventory for 2000. Atmos. Environ. 40, 4048-4063. doi:10.1016/j.atmosenv.2006.03.041 
Pak, K.-R., Bartha, R., 1998. Mercury methylation by interspecies hydrogen and acetate transfer between sulfidogens and methanogens. Appl. Environ. Microbiol. 64, 1987-1990.

Parks, J.M., Johs, A., Podar, M., Bridou, R., Hurt, R.A., Smith, S.D., Tomanicek, S.J., Qian, Y., Brown, S.D., Brandt, C.C., Palumbo, A.V., Smith, J.C., Wall, J.D., Elias, D.A., Liang, L., 2013. The genetic basis for bacterial mercury methylation. Science 339, 1332-1335. doi:10.1126/science. 1230667

Peng, X., Liu, F., Wang, W.-X., Ye, Z., 2012. Reducing total mercury and methylmercury accumulation in rice grains through water management and deliberate selection of rice cultivars. Environ. Pollut. 162, 202-208. doi:10.1016/j.envpol.2011.11.024

Peralta, A.L., Matthews, J.W., Kent, A.D., 2010. Microbial community structure and denitrification in a wetland mitigation bank. Appl. Environ. Microbiol. 76, 4207-4215. doi:10.1128/AEM.02977-09

Pickhardt, P.C., Folt, C.L., Chen, C.Y., Klaue, B., Blum, J.D., 2002. Algal blooms reduce the uptake of toxic methylmercury in freshwater food webs. Proc. Natl. Acad. Sci. 99, 4419-4423.

Podar, M., Gilmour, C.C., Brandt, C.C., Soren, A., Brown, S.D., Crable, B.R., Palumbo, A.V., Somenahally, A.C., Elias, D.A., 2015. Global prevalence and distribution of genes and microorganisms involved in mercury methylation. Sci. Adv. 1, e1500675-e1500675. doi:10.1126/sciadv.1500675

Ponnamperuma, F.N., 1972. The chemistry of submerged soils. Academic Press NY and London.

Ranchou-Peyruse, M., Monperrus, M., Bridou, R., Duran, R., Amouroux, D., Salvado, J.C., Guyoneaud, R., 2009. Overview of mercury methylation capacities among anaerobic bacteria including representatives of the sulphate-reducers: Implications for environmental studies. Geomicrobiol. J. 26, 1-8. doi:10.1080/01490450802599227

Ravichandran, M., 2004. Interactions between mercury and dissolved organic matter-a review. Chemosphere 55, 319-331. doi:10.1016/j.chemosphere.2003.11.011

Regier, N., Frey, B., Converse, B., Roden, E., Grosse-Honebrink, A., Bravo, A.G., Cosio, C., 2012. Effect of Elodea nuttallii Roots on acterial communities and $\mathrm{MMHg}$ proportion in a $\mathrm{Hg}$ polluted sediment. PLOS ONE 7, e45565.

Robinson, J.B., Tuovinen, O.H., 1984. Mechanisms of microbial resistance and detoxification of mercury and organomercury compounds: physiological, biochemical, and genetic analyses. Microbiol. Rev. 48, 95.

Rothenberg, S.E., Feng, X., 2012. Mercury cycling in a flooded rice paddy. J. Geophys. Res. 117. doi:10.1029/2011JG001800 
Rothenberg, S.E., Feng, X., Zhou, W., Tu, M., Jin, B., You, J., 2012. Environment and genotype controls on mercury accumulation in rice (Oryza sativa L.) cultivated along a contamination gradient in Guizhou, China. Sci. Total Environ. 426, 272-280. doi:10.1016/j.scitotenv.2012.03.024

Rothenberg, S.E., Windham-Myers, L., Creswell, J.E., 2014. Rice methylmercury exposure and mitigation: A comprehensive review. Environ. Res. 133, 407-423. doi:10.1016/j.envres.2014.03.001

Roy, V., Amyot, M., Carignan, R., 2009. Beaver ponds increase methylmercury concentrations in Canadian Shield streams along vegetation and pond-age gradients. Environ. Sci. Technol. 43, 5605-5611. doi:10.1021/es901193x

Rudd, J.W.M. 1995. Sources of methylmercury to freshwater ecosystems: a review. Water Air Soil Pollut. $80,697-713$.

Rumbold, D.G., Fink, L.E., 2006. Extreme spatial variability and unprecedented methylmercury concentrations within a constructed wetland. Environ. Monit. Assess. 112, 115-135.

Schaefer, J.K., Morel, F.M., 2009. High methylation rates of mercury bound to cysteine by Geobacter sulfurreducens. Nat. Geosci. 2, 123-126.

Schaefer, J.K., Rocks, S.S., Zheng, W., Liang, L., Gu, B., Morel, F.M.M., 2011. Active transport, substrate specificity, and methylation of $\mathrm{Hg}(\mathrm{II})$ in anaerobic bacteria. Proc. Natl. Acad. Sci. 108, 8714-8719. doi:10.1073/pnas.1105781108

Scheuhammer, A.M., Meyer, M.W., Sandheinrich, M.B., Murray, M.W., 2007. Effects of environmental methylmercury on the health of wild birds, mammals, and fish. AMBIO J. Hum. Environ. 36, $12-$ 19.

Scholz, M., Lee, B., 2005. Constructed wetlands: a review. Int. J. Environ. Stud. 62, 421-447. doi:10.1080/00207230500119783

Schwesig, D., Krebs, O., 2003. The role of ground vegetation in the uptake of mercury and methylmercury in a forest ecosystem. Plant Soil 253, 445-455.

Selin, N.E., 2009. Global biogeochemical cycling of mercury: A review. Annu. Rev. Environ. Resour. 34, 43-63. doi:10.1146/annurev.environ.051308.084314

Shih, R., Robertson, W.D., Schiff, S.L., Rudolph, D.L., 2011. Nitrate controls methyl mercury production in a streambed bioreactor. J. Environ. Qual. 40, 1586. doi:10.2134/jeq2011.0072

Siciliano, S.D., O’Driscoll, N.J., Tordon, R., Hill, J., Beauchamp, S., Lean, D.R.S., 2005. Abiotic production of methylmercury by solar radiation. Environ. Sci. Technol. 39, 1071-1077. doi:10.1021/es048707z 
Sinclair, K.A., Xie, Q., Mitchell, C.P.J., 2012. Methylmercury in water, sediment, and invertebrates in created wetlands of Rouge Park, Toronto, Canada. Environ. Pollut. 171, 207-215. doi:10.1016/j.envpol.2012.07.043

Skyllberg, U., Xia, K., Bloom P.R., Nater, E.A., Bleam, W.F. 2000. Binding of mercury(II) to reduced sulfur in soil organic matter along upland-peat soil transects. J. Environ. Qual. 29, 855-865.

St. Louis, V.L., Rudd, J.W., Kelly, C.A., Beaty, K.G., Bloom, N.S., Flett, R.J., 1994. Importance of wetlands as sources of methyl mercury to boreal forest ecosystems. Can. J. Fish. Aquat. Sci. 51, 1065-1076.

St. Louis, V.L., Rudd, J.W.M., Kelly, C.A., Bodaly, R.A. (Drew), Paterson, M.J., Beaty, K.G., Hesslein, R.H., Heyes, A., Majewski, A.R., 2004. The rise and fall of mercury methylation in an experimental reservoir. Environ. Sci. Technol. 38, 1348-1358. doi:10.1021/es034424f

Stamenkovic, J., Gustin, M.S., Dennett, K.E., 2005. Net methyl mercury production versus water quality improvement in constructed wetlands: trade-offs in pollution control. Wetlands 25, 748-757.

Stolt, M.H., Genthner, M.H., Daniels, W.L., Groover, V.A., Nagle, S., Haering, K.C., 2000. Comparison of soil and other environmental conditions in constructed and adjacent palustrine reference wetlands. Wetlands 20, 671-683.

Stottmeister, U., Wießner, A., Kuschk, P., Kappelmeyer, U., Kästner, M., Bederski, O., Müller, R.A., Moormann, H., 2003. Effects of plants and microorganisms in constructed wetlands for wastewater treatment. Biotechnol. Adv. 22, 93-117. doi:10.1016/j.biotechadv.2003.08.010

Strickman, R.J., Mitchell, C.P.J., 2016. Accumulation and translocation of methylmercury and inorganic mercury in Oryza sativa: An enriched isotope tracer study. Sci. Total Environ. doi:10.1016/j.scitotenv.2016.08.068

Strickman, R.J.S., Fulthorpe, R.R., Coleman Wasik, J.K., Engstrom, D.R., Mitchell, C.P.J., 2016. Experimental sulfate amendment alters peatland bacterial community structure. Sci. Total Environ. doi:10.1016/j.scitotenv.2016.05.189

Sun, X., Wang, Q., Ma, H., Wang, Z., Yang, S., Zhao, C., Xu, L., 2011. Effects of plant rhizosphere on mercury methylation in sediments. J. Soils Sediments 11, 1062-1069. doi:10.1007/s11368-0110403-y

Temme, C., Slemr, F., Ebinghaus, R., Einax, J.W., 2003. Distribution of mercury over the Atlantic Ocean in 1996 and 1999-2001. Atmos. Environ. 37, 1889-1897. doi:10.1016/S1352-2310(03)00069-4

Todorova, S. G., Driscoll, C.T., Matthews, D.A., Effler, S.W., Hines, M.E., Henry, E. A. 2009. Evidence for regulation of monomethyl mercury by nitrate in a seasonally stratified, eutrophic lake.

Environ. Sci. Technol. 43, 6572-6578. 
Trasande, L., Landrigan, P.J., Schechter, C., 2005. Public health and economic consequences of methyl mercury toxicity to the developing brain. Environ. Health Perspect. 113, 590-596. doi:10.1289/ehp.7743

Travnikov, O. 2012. Atmospheric transport of mercury, in: Liu, G., Cai, Y., O’Driscoll, N. (eds.), Environmental Chemistry and Toxicology of Mercury, first ed. John Wiley \& Sons, Inc, Hoboken, New Jersey.

Tremblay, A., Cloutier, L., Lucotte, M., 1998. Total mercury and methylmercury fluxes via emerging insects in recently flooded hydroelectric reservoirs and a natural lake. Sci. Total Environ. 219, 209-221.

Tsui, M.T.K., Finlay, J.C., 2011. Influence of dissolved organic carbon on methylmercury bioavailability across Minnesota stream ecosystems. Environ. Sci. Technol. 45, 5981-5987. doi:10.1021/es200332f

Turetsky, M.R., Harden, J.W., Friedli, H.R., Flannigan, M., Payne, N., Crock, J., Radke, L., 2006. Wildfires threaten mercury stocks in northern soils. Geophys. Res. Lett. 33. doi:10.1029/2005GL025595

Ulanowski, T.A., Branfireun, B.A., 2013. Small-scale variability in peatland pore-water biogeochemistry, Hudson Bay Lowland, Canada. Sci. Total Environ. 454-455, 211-218. doi:10.1016/j.scitotenv.2013.02.087

Ullrich, S.M., Tanton, T.W., Abdrashitova, S.A., 2001. Mercury in the aquatic environment: A review of factors affecting methylation. Crit. Rev. Environ. Sci. Technol. 31, 241-293. doi:10.1080/20016491089226

USEPA National Listing of Fish Advisories. Technical Factsheet, 2010. http://water.epa.gov/scitech/swguidance/fishshellfish/fishadvisories/upload/technical_factsheet_2 010.pdf (accessed 28.03.13)

Válega, M., Lillebø, A.I., Caçador, I., Pereira, M.E., Duarte, A.C., Pardal, M.A., 2008. Mercury mobility in a salt marsh colonised by Halimione portulacoides. Chemosphere 72, 1607-1613. doi:10.1016/j.chemosphere.2008.04.007

Vishnivetskaya, T.A., Mosher, J.J., Palumbo, A.V., Yang, Z.K., Podar, M., Brown, S.D., Brooks, S.C., Gu, B., Southworth, G.R., Drake, M.M., Brandt, C.C., Elias, D.A., 2010. Mercury and other heavy metals influence bacterial community structure in contaminated Tennessee streams. Appl. Environ. Microbiol. 77, 302-311. doi:10.1128/AEM.01715-10

Wagemann, R., Trebacz, E., Boila, G., and Lockhart, W.L. 1998. Methylmercury and total mercury in tissues of arctic marine mammals. Sci. Total Environ. 218, 19-31. 
Wang, X., Bao, Z., Lin, C.-J., Yuan, W., Feng, X., 2016. Assessment of global mercury deposition through litterfall. Environ. Sci. Technol. 50, 8548-8557. doi:10.1021/acs.est.5b06351

Wang, X., Ye, Z., Li, B., Huang, L., Meng, M., Shi, J., Jiang, G., 2014. Growing rice aerobically markedly decreases mercury accumulation by reducing both $\mathrm{Hg}$ bioavailability and the production of MeHg. Environ. Sci. Technol. 48, 1878-1885. doi:10.1021/es4038929

Ward, D.M., Nislow, K.H., Folt, C.L., 2010. Bioaccumulation syndrome: identifying factors that make some stream food webs prone to elevated mercury bioaccumulation. Ann. N. Y. Acad. Sci. 1195, 62-83. doi:10.1111/j.1749-6632.2010.05456.x

Warner, K.A., Roden, E.E., Bonzongo, J.-C., 2003. Microbial mercury transformation in anoxic freshwater sediments under iron-reducing and other electron-accepting conditions. Environ. Sci. Technol. 37, 2159-2165. doi:10.1021/es0262939

Weaver, M.A., Zablotowicz, R.M., Krutz, L.J., Bryson, C.T., Locke, M.A., 2012. Microbial and vegetative changes associated with development of a constructed wetland. Ecol. Indic. 13, 37-45. doi:10.1016/j.ecolind.2011.05.005

Windham-Myers, L., Fleck, J.A., Ackerman, J.T., Marvin-DiPasquale, M., Stricker, C.A., Heim, W.A., Bachand, P.A.M., Eagles-Smith, C.A., Gill, G., Stephenson, M., Alpers, C.N., 2014. Mercury cycling in agricultural and managed wetlands: A synthesis of methylmercury production, hydrologic export, and bioaccumulation from an integrated field study. Sci. Total Environ. 484, 221-231. doi:10.1016/j.scitotenv.2014.01.033

Windham-Myers, L., Marvin-Dipasquale, M., Krabbenhoft, D.P., Agee, J.L., Cox, M.H., HerediaMiddleton, P., Coates, C., Kakouros, E., 2009. Experimental removal of wetland emergent vegetation leads to decreased methylmercury production in surface sediment. J. Geophys. Res. 114. doi:10.1029/2008JG000815

Wolf, K.L., Ahn, C., Noe, G.B., 2011. Development of soil properties and nitrogen cycling in created wetlands. Wetlands 31, 699-712. doi:10.1007/s13157-011-0185-4

Xu, X., Zhao, J., Li, Y., Fan, Y., Zhu, N., Gao, Y., Li, B., Liu, H., Li, Y.-F., 2016. Demethylation of methylmercury in growing rice plants: An evidence of self-detoxification. Environ. Pollut. 210, 113-120. doi:10.1016/j.envpol.2015.12.013

Yin, R., Feng, X., Li, X., Yu, B., Du, B., 2014. Trends and advances in mercury stable isotopes as a geochemical tracer. Trends Environ. Anal. Chem. 2, 1-10. doi:10.1016/j.teac.2014.03.001

Yu, R.-Q., Adatto, I., Montesdeoca, M.R., Driscoll, C.T., Hines, M.E., Barkay, T., 2010. Mercury methylation in Sphagnum moss mats and its association with sulfate-reducing bacteria in an acidic Adirondack forest lake wetland. FEMS Microbiol. Ecol. 74, 655-668. doi:10.1111/j.15746941.2010.00978.x 
Yuan, Y., 2012. Methylmercury: A potential environmental risk factor contributing to epileptogenesis. NeuroToxicology 33, 119-126. doi:10.1016/j.neuro.2011.12.014

Zhang, H., Feng, X., Larssen, T., Qiu, G., Vogt, R.D., 2010. In Inland China, rice, rather than fish, is the major pathway for methylmercury exposure. Environ. Health Perspect. 118, 1183-1188. doi:10.1289/ehp.1001915

Zhang, T., Kim, B., Levard, C., Reinsch, B.C., Lowry, G.V., Deshusses, M.A., Hsu-Kim, H., 2012. Methylation of mercury by bacteria exposed to dissolved, nanoparticulate, and microparticulate mercuric sulfides. Environ. Sci. Technol. 46, 6950-6958. doi:10.1021/es203181m

Zhang, Y., Jacob, D. J., Horowitz, H.M., Chen, L., Amos, H.M., Krabbenhoft, D.P., Slemr, F., St. Louis, V.L., Sunderland, E.M. 2016. Observed decrease in atmospheric mercury explained by global decline in anthropogenic emissions. Proc. Nat. Acad. Sci. 113, 526-531

doi/10.1073/pnas.1516312113 
Chapter 2

Methylmercury production and accumulation in urban stormwater and habitat wetlands 


\subsection{Abstract}

Stormwater management wetlands and created habitat wetlands effectively manage erosion, flooding, and pollutant loadings while providing biodiversity and aesthetic benefits, but these structures are also potential sources of methylmercury $(\mathrm{MeHg})$, a bioaccumulative neurotoxin. While $\mathrm{MeHg}$ accumulation has been confirmed in habitat wetlands, the extent of $\mathrm{MeHg}$ production and accumulation in stormwater wetlands is unknown. Additionally, the fine-scale variation in $\mathrm{MeHg}$ in these wetlands has never been explored, despite the possibility that cycles of wetting and drying, and the presence of aquatic plants, may stimulate methylation at their margins. To address these knowledge gaps, we compare $\mathrm{MeHg}$, inorganic mercury, the percent of mercury present as $\mathrm{MeHg}(\% \mathrm{MeHg})$, and potential mercury methylation rate constants $\left(\mathrm{K}_{\text {meth }}\right)$ in the sediments of terrestrial-aquatic transects through several stormwater and habitat wetlands. We present novel evidence confirming the in situ production of $\mathrm{MeHg}$ in both stormwater and habitat wetlands, but observe no systematic differences across the terrestrial-aquatic gradient, suggesting that routine variations in water level do not alter $\mathrm{MeHg}$ production and accumulation. Stormwater wetlands effectively trap mercury while converting relatively little to $\mathrm{MeHg}$, as evidenced by lower $\mathrm{MeHg}, \% \mathrm{MeHg}$, and $\mathrm{K}_{\text {meth }}$ values than habitat wetlands, but often greater total $\mathrm{Hg}$ concentrations. The relationship of aquatic vegetation to $\mathrm{MeHg}$ accumulation is weak and ambiguous, suggesting plants are not strong drivers of $\mathrm{MeHg}$ biogeochemistry in these systems. Although the $\mathrm{MeHg}$ hazard associated with individual artificial wetlands is low, they may be important sources of $\mathrm{MeHg}$ at the landscape level.

\subsection{Introduction}

Surface-flow artificial wetlands are constructed and managed wetland environments, whose purpose is to reduce erosion, flooding, and pollution, while maintaining a functional hydrological cycle at the landscape level (Scholz and Lee, 2005). In Canada, two important subcategories of surface-flow artificial wetlands are wet stormwater management wetlands and created habitat wetlands, collectively referred to here as artificial wetlands. Habitat wetlands are designed, sited, and managed primarily to provide habitat for aquatic and riparian organisms. They are usually located in less urbanized areas, and are managed to promote native species and/or species of special conservation interest (Hammer, 1992). Stormwater wetlands, in addition to providing 
hydrologic storage in urban and suburban areas, are generally constructed close to sources of lightly contaminated water, such as runoff from roads and parking lots, and are managed to improve the water quality of storm runoff (Ontario Ministry of the Environment, 2003). Artificial wetlands of both varieties are generally a relatively inexpensive and effective management option, making them widely used in the expanding urban and suburban landscape of North America (Scholz and Lee, 2005; Smith et al., 2002).

Many natural wetland systems are sites of methylmercury ( $\mathrm{MeHg}$ ) production (Galloway and Branfireun, 2004; Hall et al., 2008; St. Louis et al., 1994), a bioaccumulative neurotoxin of global concern (Mergler et al., 2007). Methylmercury is synthesized from inorganic $\mathrm{Hg}^{2+}(\mathrm{IHg}$ ), which enters the system through atmospheric deposition or in runoff, and subsequently accumulates in sediments. Mercury $(\mathrm{Hg})$ methylation is carried out by sulfate reducing, iron reducing, methanogenic and other microbes, and occurs mainly in anoxic aquatic environments (Gilmour et al., 2013; Podar et al., 2015). Methylmercury can also be demethylated via both biotic and abiotic degradation pathways (Li and Cai, 2012). The balance between methylation and demethylation thus controls the net $\mathrm{MeHg}$ accumulation of a system. Net $\mathrm{MeHg}$ accumulation varies greatly between different ecosystems in response to a range of factors, including the bioavailability of $\mathrm{IHg}$, supply of metabolic substrates, availability of labile carbon, dissolved organic carbon (DOC) concentration and quality, sediment organic matter content, temperature, $\mathrm{pH}$, and the activity of mercury methylating organisms (Hsu-Kim et al., 2013; Munthe et al., 2007; Ravichandran, 2004; Tjerngren et al., 2011). Many of these factors, particularly controls on the bioavailability of IHg, are poorly understood, making it difficult to predict the likely MeHg accumulation capacity of a wetland.

Like other aquatic environments, artificial wetlands are sites of net $\mathrm{MeHg}$ accumulation, potentially offsetting their many valuable ecosystem services (Sinclair et al., 2012; Stamenkovic et al., 2005). Mitigating MeHg accumulation in these managed environments is possible, for instance by altering the trophic structure of aquatic food webs, removing organic matter, or adding chemical coagulants (Mailman et al., 2006; McCord and Heim, 2015) but these measures can be expensive and compromise other management goals, such as habitat provision (McCord and Heim, 2015). To effectively mitigate $\mathrm{MeHg}$ issues, engineers and wetland managers require a more robust understanding of the extent and distribution of $\mathrm{MeHg}$ accumulation in artificial 
wetland systems. In particular, the extent of $\mathrm{MeHg}$ production in stormwater wetlands is currently unknown. Mercury methylation has been confirmed in temperate, created habitat wetlands (Sinclair et al., 2012) and subtropical or desert water treatment wetlands (Chavan et al., 2007; Feng et al., 2014; Rumbold and Fink, 2006; Stamenkovic et al., 2005) but has not been investigated in surface-flow stormwater management wetlands in temperate climates. Factors known to affect net $\mathrm{MeHg}$ accumulation, including $\mathrm{pH}$ and organic matter accumulation, vary between stormwater and similar small natural wetlands (Woodcock et al., 2010), suggesting a need to separately quantify the $\mathrm{MeHg}$ accumulation capacity of stormwater wetlands rather than extrapolating from habitat wetlands or small natural wetlands.

The spatial variability of MeHg production processes within individual surface-flow artificial wetlands is also entirely unknown, an important knowledge gap given the fact that marked spatial variability in $\mathrm{MeHg}$ concentrations can be found in natural wetlands (Mitchell et al., 2008). Surface-flow artificial wetlands are usually shallow and designed with excess holding capacity to deal with the pulsed hydrology associated with stormflow (Ontario Ministry of the Environment, 2003). Thus, these wetlands are subject to frequent and extensive cycles of wetting and drying (Kadlec and Wallace, 2009). Drying-rewetting cycles have been observed to increase MeHg production and bioaccumulation, potentially as a result of aerobic reoxidation of sulfide to sulfate, followed by stimulation of sulfate-reducing mercury methylators upon rewetting (Coleman Wasik et al., 2015; Feng et al., 2014; Oswald and Carey, 2016). This observation suggests that cycles of wetting and drying, and wetland designs that increase the spatial extent of frequently exposed wetland margins, may increase the production of $\mathrm{MeHg}$ in surface-flow artificial wetlands. The distribution of plants in these habitats may also contribute to spatial variability. Emergent aquatic plants make important functional contributions to the water storage and contaminant removal efficiency of artificial wetlands (Brix, 1997), but they have also been found to increase net $\mathrm{MeHg}$ accumulation in rice fields (Windham-Myers et al., 2009) and natural wetlands (Canário et al., 2007; O'Driscoll et al., 2011). Plants may stimulate mercurymethylating prokaryotes via the release of labile carbon from root exudates or through the regeneration of metabolic substrates at the oxygenated rhizosphere-bulk sediment interface (Cosio et al., 2014). Most artificial wetlands incorporate areas of dense vegetation, and the possibility that more heavily vegetated areas may have higher burdens of $\mathrm{MeHg}$ is a serious 
consideration for designers and managers of artificial wetlands. Overall, a better understanding of any spatial patterns in $\mathrm{MeHg}$ accumulation in surface-flow artificial wetlands may suggest alternate construction strategies or management practices.

In this project, we characterized and compared $\mathrm{MeHg}$ concentrations and production in wetlands that were managed either for stormwater control or habitat provision. Additionally, we investigated relationships between the presence and abundance of aquatic plants with $\mathrm{MeHg}$ concentrations, and systematically examined $\mathrm{MeHg}$ production and accumulation along the terrestrial-aquatic gradient of individual wetlands. This project aimed to simultaneously extend understanding of $\mathrm{Hg}$ transformations in surface-flow artificial wetlands in a temperate climate, and to provide evidence-based guidance for wetland managers concerned with balancing the many benefits of surface-flow artificial wetlands with their potential as sources of $\mathrm{MeHg}$.

\subsection{Material and Methods}

\subsubsection{Sampling Sites}

We examined $\mathrm{MeHg}$ production and accumulation in nine surface-flow artificial wetlands in the Greater Toronto area in Ontario, Canada. Study wetlands had been constructed between $<1$ and 14 years prior to sampling, ranged in size from 0.43-1.9 hectares, and in maximum water depth from 10-112 cm (wetland characteristics in Table 2.1). All sites were continuously wetted at the center of the wetland, with a defined inlet and outlet. Seven wetlands were surveyed in 2012, with an additional two sites added to the project in 2013. In 2012, four habitat wetlands and three stormwater wetlands were sampled once between July and October. Habitat wetlands (Habitat-1

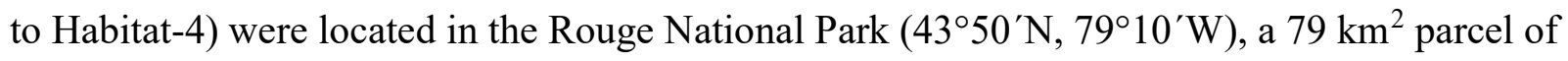
agricultural and forested land traversed by several railways and large roads. The three stormwater wetlands assessed in 2012 were located on the grounds of Toronto Pearson International Airport $\left(43^{\circ} 40^{\prime} \mathrm{N}, 79^{\circ} 37^{\prime} \mathrm{W}\right)$. These wetlands treated road and runway effluent (Storm-3, Storm-4) or de-icing water (Storm-5). In the summer of 2013, two additional stormwater sites were surveyed in the City of Brampton $\left(43^{\circ} 43^{\prime} \mathrm{N}, 79^{\circ} 45^{\prime} \mathrm{W}\right)$, a large municipality directly to the northwest of Toronto. These sites were constructed as part of the stormwater management strategies of housing developments then in the early (Storm-1) or late (Storm-2) stages of construction. 


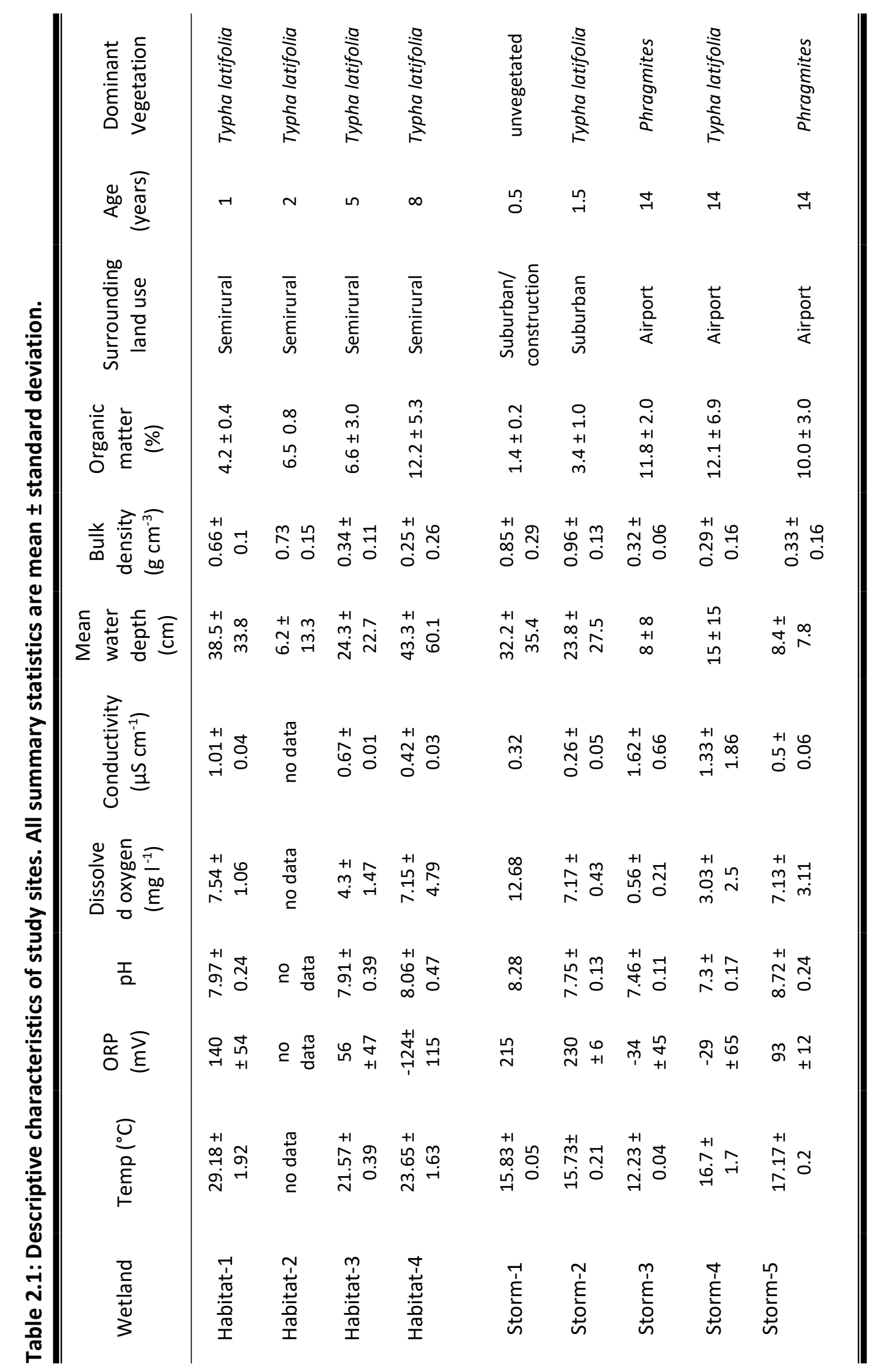




\subsubsection{Sample Collection}

Three to five points along the terrestrial-aquatic continuum, identified by vegetation transitions, were assessed in each wetland. Beginning at the terrestrial margin, a sampling site was established at the extent of aquatic influence (shore), identified as either the transition between characteristic aquatic and terrestrial plants, the edge of the water, or the high water mark, whichever was furthest from the center of the wetland. If the shore was identified by the extent of standing water or high water mark, an additional site was sampled at the outer margin of aquatic vegetation (OMAV). Moving towards the aquatic area of the wetland, samples were collected at the center of emergent aquatic vegetation (center of aquatic vegetation), the transition between emergent aquatic vegetation and open water (inner margin of aquatic vegetation), and the center of the wetland or point of deepest accessible open water (center of the wetland). In two cases, the wetland was completely vegetated, and the inner margin of aquatic vegetation and wetland center were congruous. In each of these ecological zones, standard water quality variables were measured, plant area coverage and biomass were assessed, and sediment cores were collected. Water quality variables included $\mathrm{pH}$, temperature, conductivity, dissolved oxygen content, and redox potential were measured in the overlying water using a handheld YSI Sonde 600 QS multiprobe water quality meter, which was calibrated daily. The canopy coverage of vegetation (the amount of ground surface obstructed from view by any plant part) was visually estimated in a $1 \mathrm{~m}^{2}$ quadrat (Elzinga et al., 1998). Dead but rooted plant tissue was included in these estimates, while detritus was not. One sediment core was collected from the center of each quadrat using a $4.7 \mathrm{~cm}$ ID clear polycarbonate tube, capped, and stored upright in a cooler for transport. All aboveground plant biomass, including submerged aquatics and algae, was collected from a $30 \mathrm{~cm}$ radius around the core collection point. Again, dead but rooted plant tissue was collected, while detritus was not.

\subsubsection{Mercury Methylation Assays}

In the lab, sediment cores were amended with an enriched, sable Hg isotope to assess potential $\mathrm{Hg}$ methylation rate constants, with simultaneous analysis of ambient total mercury $(\mathrm{THg})$ and MeHg concentrations as per methods described in Hintelmann and Evans (1997). A 96.17\% enriched ${ }^{201} \mathrm{HgCl}$ solution was diluted with filtered $(0.7 \mu \mathrm{m}$ glass fiber filter) local pore water to a final $\mathrm{Hg}$ concentration of $12 \mu \mathrm{g} \mathrm{ml}^{-1}$, and left to equilibrate for one hour, presumably allowing 
for speciation of the inorganic $\mathrm{Hg}$ tracer to closely mimic what would be observed in each wetland's pore water. This solution was then injected using a gas-tight syringe into the core at 1$\mathrm{cm}$ intervals through pre-drilled and silicon covered septa, yielding a $\mathrm{Hg}$ tracer concentration equal to or less than the THg levels expected to be present in the sediments, based on previous explorations of similar sites (Sinclair et al., 2012). Cores were incubated in the dark at $22^{\circ} \mathrm{C}$ for 19 hours. Based on the increased rate of $\mathrm{Hg}$ transformations at the oxic-anoxic boundary in aquatic ecosystems (Eckley et al., 2015; Goulet et al., 2007), we focused on the top 0-2 cm layer for further analysis. Cores were extruded and the top 0-2 cm of sediment immediately frozen. Subsections of each sample were used to determine bulk density and organic matter content, using the loss-on-ignition method (4 hours at $550^{\circ} \mathrm{C}$ ).

\subsubsection{Mercury Analyses}

Methylmercury concentrations in sediment were assessed using isotope dilution-gas chromatography-inductively coupled plasma mass spectrometry (ID-GC-ICPMS) (Hintelmann and Evans 1997, Hintelmann and Ogrinc 2003). Briefly, samples that had been spiked with a known concentration of enriched $\mathrm{Me}^{199} \mathrm{Hg}$ as an internal standard were distilled similar to the method of Horvat et al. (1993) in Teflon vessels that had been rigorously acid-cleaned. Mercury species, including MeHg, were ethylated using sodium tetraethylborate, liberated from solution by purging with high-purity nitrogen, and concentrated onto a glass trap packed with Tenax ${ }^{\circledR}$. Tenax ${ }^{\circledR}$ traps were thermally desorbed into a stream of argon gas, passed through a chromatographic column, and directly introduced to an Agilent 7700x ICP-MS. The concentrations of both ambient $\mathrm{MeHg}$, and newly formed $\mathrm{Me}^{201} \mathrm{Hg}$ were calculated based on isotope ratios and the concentration of the internal standard $\left(\mathrm{Me}^{199} \mathrm{Hg}\right)$ using the method of Hintelmann and Evans (1997). The potential methylation rate constant $\left(K_{\text {meth }}\right)$, a variable that estimates the rate at which $\mathrm{IHg}$ is converted to $\mathrm{MeHg}$ on a per-time basis, was calculated after Drott et al. (2008). Since these values are calculated using the conversion of newly added isotopic $\mathrm{Hg}(\mathrm{II})$, which is more bioavailable than native $\mathrm{Hg}$ (Hintelmann et al., 2000), $\mathrm{K}_{\text {meth }}$ thus expresses the potential, rather than actual, methylation capacity of a matrix.

For THg analysis, $0.2-0.3 \mathrm{~g}$ of dry sediment was digested in $10 \mathrm{~mL}$ of hot nitric acid until vapors lost their color. Digestates were diluted with deionized water and oxidized to $\mathrm{Hg}^{2+}$ with $0.5 \mathrm{~mL}$ 
BrCl. Using a Tekran $2600 \mathrm{Hg}$ analysis system to automate the process, $\mathrm{Hg}^{2+}$ in digestates was reduced to $\mathrm{Hg}^{0}$ with $\mathrm{SnCl}_{2}$ and amalgamated onto dual gold-traps. Gold traps were thermally desorbed in sequence and $\mathrm{Hg}$ was delivered directly to the ICP-MS instrument via a stream of high-purity argon, allowing the quantification of individual $\mathrm{Hg}$ isotopes. Inorganic $\mathrm{Hg}$ was estimated as $\mathrm{THg}$ concentration minus $\mathrm{MeHg}$ concentration.

Quality control was assessed through analysis of blanks (deionized water), duplicate samples, certified reference materials (ERM CC580 for MeHg; MESS-3 for THg) and matrix sample spikes (THg only). Method detection limits, corrected for average mass of sample digested $(0.3 \mathrm{~g})$, were calculated as three times the standard deviation of blank samples. These data are displayed in Table 2.2.

Table 2.2: Quality control data for MeHg and THg determinations

\begin{tabular}{|c|c|c|c|c|c|}
\hline & Ambient MeHg & $\begin{array}{c}\text { Excess } \\
\mathrm{Me}^{201} \mathrm{Hg}\end{array}$ & $\mathrm{K}_{\text {meth }} *$ & Ambient THg & $\begin{array}{l}\text { Excess } \\
\mathrm{T}^{201} \mathrm{Hg}\end{array}$ \\
\hline $\begin{array}{l}\text { Certified } \\
\text { reference material } \\
\text { (CRM) }\end{array}$ & CC580 & & & MESS-3 & \\
\hline $\begin{array}{l}\text { CRM average } \\
\text { recovery (\%) }\end{array}$ & $117 \pm 8 \quad(n=16)$ & & & $102 \pm 7.1(n=8)$ & \\
\hline Average duplicate & $4.2 \pm 2.5$ & $15 \pm 14$ & & $7.5 \pm 11.1$ & $4.2 \pm 3.2$ \\
\hline RSD (\%) & ( $n=12$ pairs) & ( $n=12$ pairs) & & ( $n=8$ pairs $)$ & ( $n=8$ pairs $)$ \\
\hline Spike recovery (\%) & & & & $105 \pm 3.5(n=8)$ & \\
\hline Detection limit & $0.013 \mathrm{ng} \mathrm{g}^{-1}$ & $0.011 \mathrm{ng} \mathrm{g}^{-1}$ & $\begin{array}{c}0.03-0.82 \\
\mathrm{ng} \mathrm{g}^{-1}\end{array}$ & $0.02 \mathrm{ng} \mathrm{g}^{-1}$ & $0.01 \mathrm{ng} \mathrm{g}^{-1}$ \\
\hline
\end{tabular}




\subsubsection{Data Analysis}

Normality was assessed using q-q plots and frequency distribution histograms, and transformed to approximate a normal distribution using log, natural $\log$, or square root transformations as necessary. Homogeneity of variance was tested using Levene's test. Mercury variables were compared between wetland types and ecological zones using nested two-way ANCOVA tests, with age of the wetland as the covariate. Pearson correlation matrices at $\alpha \leq 0.05$ were used to examine relationships between individual variables across either stormwater or habitat wetlands. All analyses were conducted in R, version 3.3.1 (R Core Team, 2016).

\subsection{Results and Discussion}

\subsubsection{Mercury Methylation in Stormwater and Habitat Wetlands}

Both stormwater and habitat wetlands clearly accumulate and can produce MeHg. Methylmercury concentrations in wetland sediment were significantly lower in stormwater $(0.46$ $\left.\pm 0.28 \mathrm{ng} \mathrm{g}^{-1}\right)$ than in habitat $\left(2.00 \pm 1.08 \mathrm{ng} \mathrm{g}^{-1}\right)$ wetlands $\left(\mathrm{F}_{(1,26)}=24.89 \mathrm{p}=0.001\right.$, Figure $2.1 \mathrm{~b})$. The proportion of $\mathrm{Hg}$ present as $\mathrm{MeHg}(\% \mathrm{MeHg})$, a variable which integrates ongoing $\mathrm{Hg}$ methylation and demethylation and reflects the long-term $\mathrm{MeHg}$ accumulation in sediment (Drott et al., 2008), was also significantly less in stormwater than in habitat wetlands $\left(\mathrm{F}_{(1,26)}=\right.$ 27.19, $\mathrm{p}<0.001$, Figure 2.1c). Active Hg methylation in the sediment of these wetlands was confirmed through measurements of methylation rate constants $\left(\mathrm{K}_{\mathrm{meth}}\right)$, which ranged from 0.006 \pm 0.004 day $^{-1}$ in stormwater to $0.014 \pm 0.010$ day $^{-1}$ in habitat wetlands (Figure 2.1d). These findings, which are similar to $\mathrm{K}_{\text {meth }}$ and $\% \mathrm{MeHg}$ values in other freshwater wetland systems (Drott et al., 2008; Hoggarth et al., 2015; Marvin-DiPasquale et al., 2014; Tjerngren et al., 2011) indicate, for the first time, that in situ methylation of $\mathrm{Hg}^{2+}$ is most likely the main source of $\mathrm{MeHg}$ to these systems, and that the MeHg production capacity of these artificial systems was not markedly higher or lower than that of better-studied natural wetlands. While both types of wetlands are capable of producing $\mathrm{MeHg}$, the significantly smaller $\mathrm{MeHg}$ concentrations and $\% \mathrm{MeHg}$ values in stormwater wetlands indicate significantly dampened $\mathrm{Hg}$ methylation processes in comparison to those observed in created habitat wetlands. 

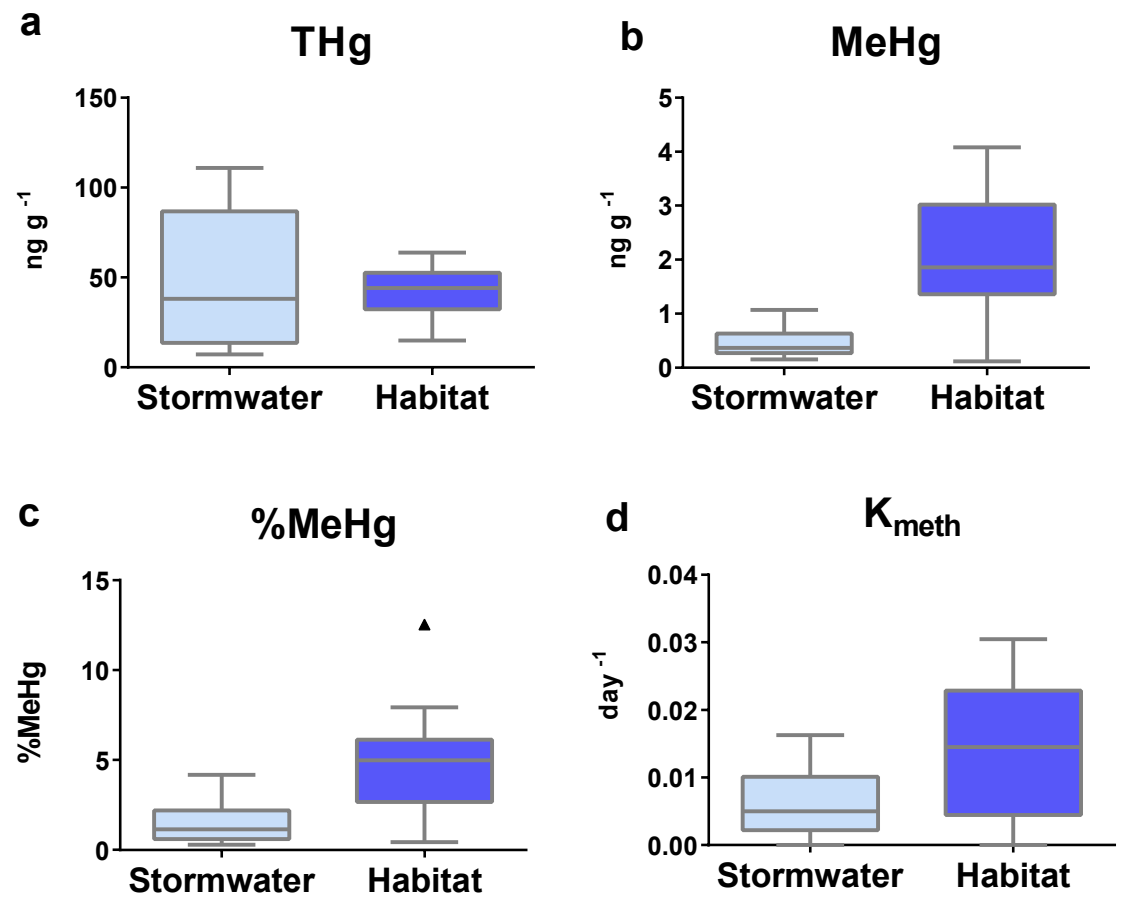

Figure 2.1: Comparison between stormwater and habitat wetlands of a) sediment total mercury (THg) concentrations, b) sediment methylmercury (MeHg) concentrations, c) percent of sediment mercury present as methylmercury $(\% \mathrm{MeHg}), \mathrm{d})$ potential methylation rate constant $\left(\mathrm{K}_{\text {meth }}\right)$. All data are presented as median (central line) $25^{\text {th }}$ and $75^{\text {th }}$ percentiles (filled boxes) with Tukey whiskers representing outlying data within 1.5 times the interquartile range.

Methylmercury production and accumulation appear to be regulated by different processes in the two wetland types. In habitat wetlands, $\mathrm{MeHg}$ concentrations were not related to $\mathrm{IHg}$ concentrations $(\mathrm{p}=0.145)$, but did correlate strongly with $\% \mathrm{MeHg}(\mathrm{p}>0.001, \mathrm{r}=0.85$; Figure 2). These results indicate that the net accumulation of $\mathrm{MeHg}$ in the sediments is not wellrepresented by the total amount of $\mathrm{IHg}$ in the system. Rather, \% $\mathrm{MeHg}$ values were likely driven by a myriad of factors, such as geochemical impacts on IHg bioavailability, the abundance and activity of $\mathrm{Hg}$ methylating microorganisms, or the rate of demethylation. The fraction of inorganic $\mathrm{Hg}(\mathrm{II})$ which is bioavailable for uptake by $\mathrm{Hg}$ methylating microorganisms is determined by interactions between $\mathrm{IHg}$, and the concentration and characteristics of natural organic matter and other Hg-binding ligands, which vary greatly between environments and are difficult to model effectively (Hsu-Kim et al 2013). As a result, $\mathrm{MeHg}$ and measured $\mathrm{IHg}$ concentrations are frequently decoupled, with the result that other factors, such as the availability 
of metabolic substrates, are more useful for predicting the activity of mercury methylators and thus the MeHg concentration in sediment (Benoit et al. 2003). In stormwater wetlands, there was a significant and positive, but somewhat weak correlation between $\mathrm{MeHg}$ and $\operatorname{IHg}(\mathrm{p}=0.007, \mathrm{r}=$ 0.59; Figure 2.2), suggesting that the bioavailable fraction of $\mathrm{IHg}$ was less variable than in habitat wetlands. This means that measured IHg concentrations were a better, but still imperfect proxy for the amount of bioavailable IHg that could be methylated in stormwater wetlands. Although a more marginally significant finding $\left(\mathrm{F}_{(1,26)}=4.44, \mathrm{p}=0.072\right)$, the lower $\mathrm{K}_{\text {meth }}$ values observed in stormwater wetlands suggest that decreased activity or abundance of the mercury methylating microflora likely drives the lower $\mathrm{MeHg}$ levels in stormwater wetlands. These disparities suggest that the biogeochemistry of $\mathrm{MeHg}$ production in stormwater wetlands differs from that of wetlands managed for habitat provision.
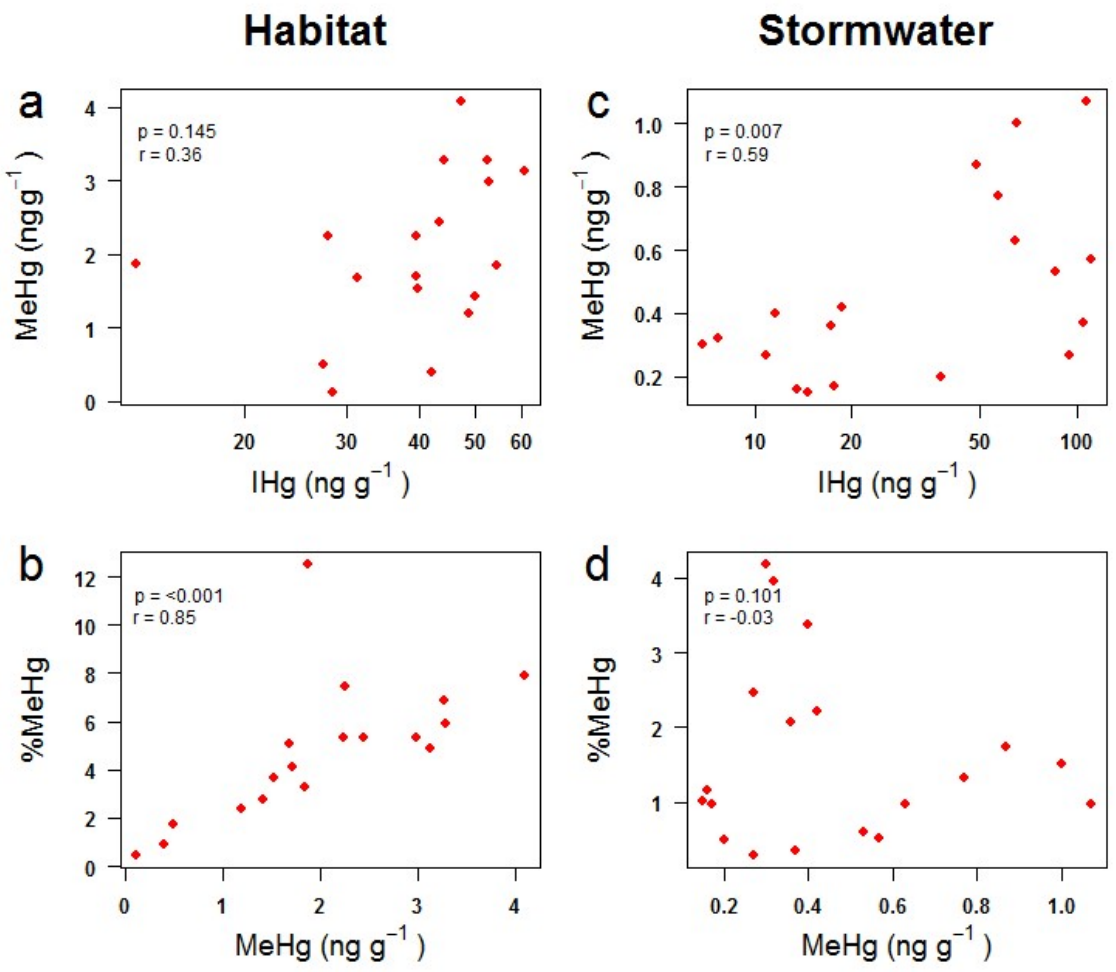

Figure 2.2: Correlations between methylmercury ( $\mathrm{MeHg}$ ) variables in habitat (left) and stormwater (right) wetlands. Results of Pearson correlations, obtained from transformed data, are displayed in the upper left corner. $\mathrm{MeHg}$ and $\% \mathrm{MeHg}$ values were log transformed, and $\mathrm{IHg}$ values were natural $\log$ transformed. 


\subsubsection{Relationship of Wetland Age to Hg Biogeochemistry}

Wetland age, although not the focus of the study, was clearly related to $\mathrm{Hg}$ patterns, particularly in stormwater wetlands (Figure 2.3). Inorganic $\mathrm{Hg}$ concentrations increased significantly with wetland age $(\mathrm{p}<0.001, \mathrm{r}=0.94)$, from $11.73 \pm 4.94 \mathrm{ng} \mathrm{g}^{-1}$ in the youngest site, then six months old, to $77.73 \pm 26.33 \mathrm{ng} \mathrm{g}^{-1}$ in the two fourteen-year-old, mature stormwater wetlands (Figure 2.3a). This pattern likely represents the cumulative storage of $\mathrm{Hg}$ derived from road and runway runoff over time (Eckley and Branfireun, 2008). Mercury has a strong affinity for thiol groups and binds to organic matter and cation exchange sites in sediment (Ullrich et al., 2001). Sediment organic matter also increased significantly with age in stormwater wetlands $(r=0.92, p<0.001)$, suggesting that, in these sites, the presence of aquatic plants and their organic detritus likely contribute to the wetland's function as an IHg sink (Jacob and Otte, 2003).

In stormwater wetlands, absolute $\mathrm{MeHg}$ concentrations also increased significantly, but slightly with wetland age $(p=0.004, r=0.63$; Fig $2 c)$. This pattern contrasts with previous research relating $\mathrm{MeHg}$ burdens to wetland age, wherein $\mathrm{MeHg}$ concentrations, as well as $\% \mathrm{MeHg}$, are generally highest in newly created wetlands and subsequently decline (Roy et al., 2009; Sinclair et al., 2012; St. Louis et al., 2004). This phenomenon is attributed to the rapid degradation of the organic matter stored in flooded sediments or standing vegetation (Hall et al., 2005). We observed such a decrease in the habitat wetlands, which showed a general decline in $\mathrm{MeHg}$ concentrations over time, from a mean concentration of $2.77 \pm 0.90 \mathrm{ng} \mathrm{g}^{-1}$ in the two-year-old wetland, to a lowest concentration of $0.83 \pm 0.92 \mathrm{ng} \mathrm{g}^{-1}$ in the oldest site, which had been created eight years before sampling (Figure 2.3d). The differing pattern observed across the chronosequence of stormwater wetlands may be related to the organic-matter poor sediments of the new stormwater wetlands, which were lined with clay and received minimal additions of organic matter prior to floodup (David Kenth, personal communication). Indeed, these sites had the lowest organic matter content of any wetland surveyed (Table 2.1). This lack of sediment organic matter would have provided little substrate for microbial activity, thus limiting $\mathrm{MeHg}$ production (Meng et al., 2016). Supporting this interpretation, the organic matter content of stormwater sediments correlated strongly and positively with both wetland age $(\mathrm{p}<0.001, \mathrm{r}=$ $0.92)$ and sediment $\mathrm{MeHg}$ concentration $(\mathrm{p}=0.001, \mathrm{r}=0.70)$. 

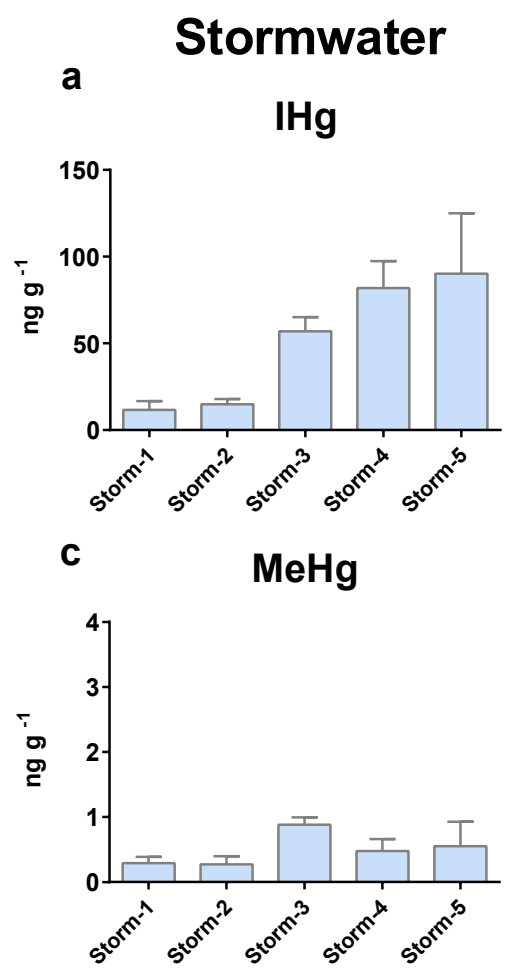

b Habitat

$\mathrm{IHg}$
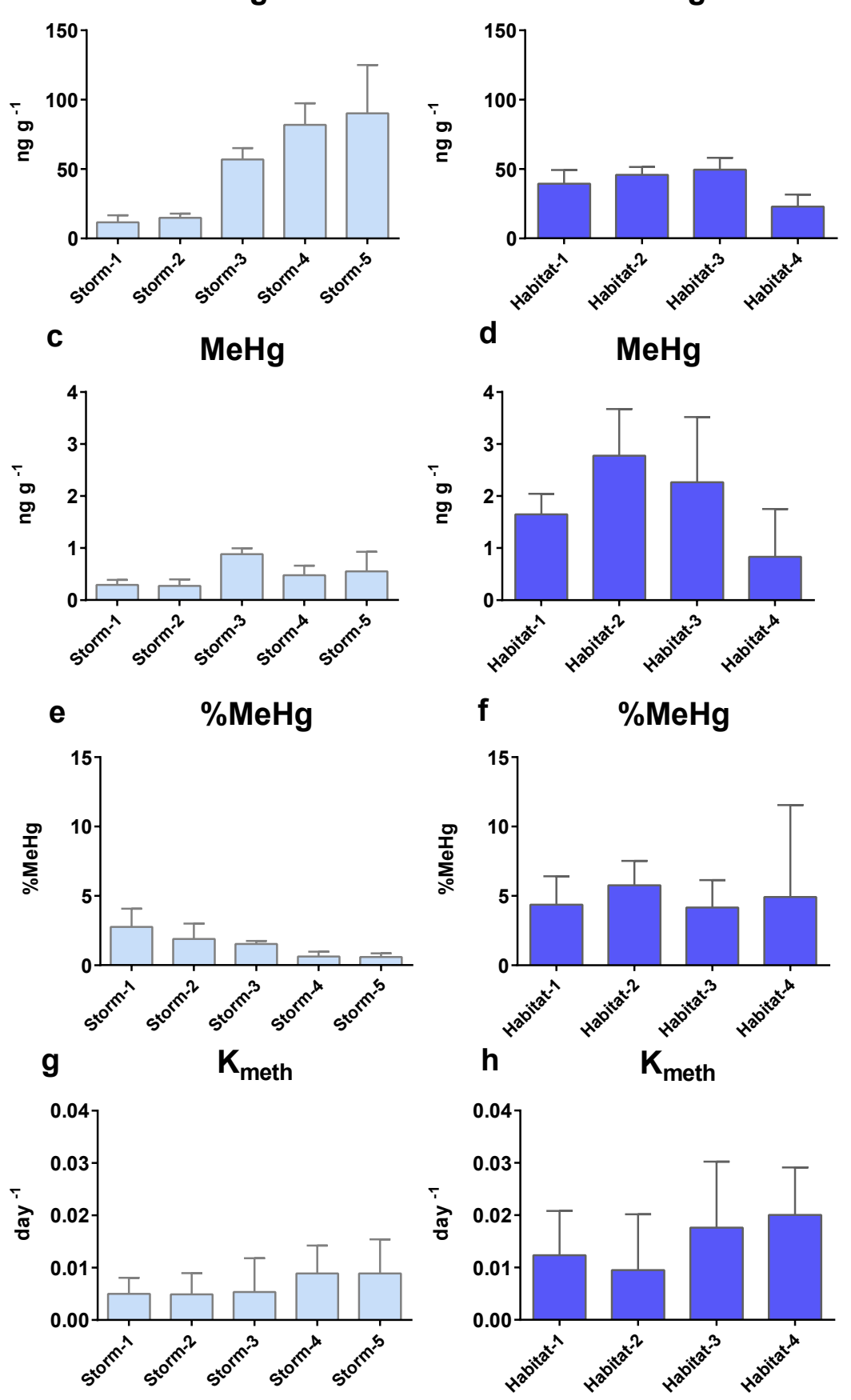

Figure 2.3: Concentrations of sediment inorganic mercury ( $\mathrm{IHg})$, sediment methylmercury (MeHg), the percent of sediment total mercury present as methylmercury $(\% \mathrm{MeHg})$, and potential mercury methylation rate constants $\left(\mathrm{K}_{\text {meth }}\right)$ in sediment from stormwater (left) and habitat (right) wetlands. Data are presented as mean \pm standard deviation. 


\subsubsection{Variation in Hg Biogeochemistry across Ecological Zones}

Ecological zones did not differ on the basis of any $\mathrm{Hg}$ variable in either stormwater or habitat wetlands $\left(\mathrm{F}_{(7-8,26)}=0.60-2.87\right.$, p-values $0.124-0.976$; Figure 2.4$)$. There was a general declining trend in $\mathrm{K}_{\text {meth }}$ values from the center of stormwater wetlands towards the shore (Figure 2.4d), but these differences were not significant. This lack of variation in $\mathrm{Hg}$ biogeochemistry across the aquatic-terrestrial gradient indicates that, in contrast to expectations, drying-rewetting cycles in surface-flow artificial wetlands likely do not enhance $\mathrm{MeHg}$ accumulation at these wetland margins. The existing observations that link dryout-rewetting events in small wetlands with increased $\mathrm{MeHg}$ production have been based on extreme droughts that greatly lowered the water table or resulted in complete dryout (Coleman Wasik et al., 2015; Feng et al., 2014), or floods which inundated areas of the wetland that were normally never flooded (Oswald and Carey, 2016). The fluctuations experienced by our study sites were within the design specifications of the wetlands and did not result in complete dryout, nor were large areas of the margins flooded. The lack of clear spatial patterning also implies that $\mathrm{MeHg}$ production and accumulation is unlikely to be affected by wetland designs that alter the relative abundance of littoral and pelagic ecotypes, such as the creation of mid-bay bars or islands or extensive areas of shallow water, design features which improve habitat value and public safety (Ontario Ministry of the Environment, 2003). However, the effects of extreme dryout on MeHg biogeochemistry in artificial wetlands should be investigated, particularly in the context of stormwater wetland dredging, a frequent management activity that involves completely draining the wetland and removing accumulated sediment. 
Stormwater

a
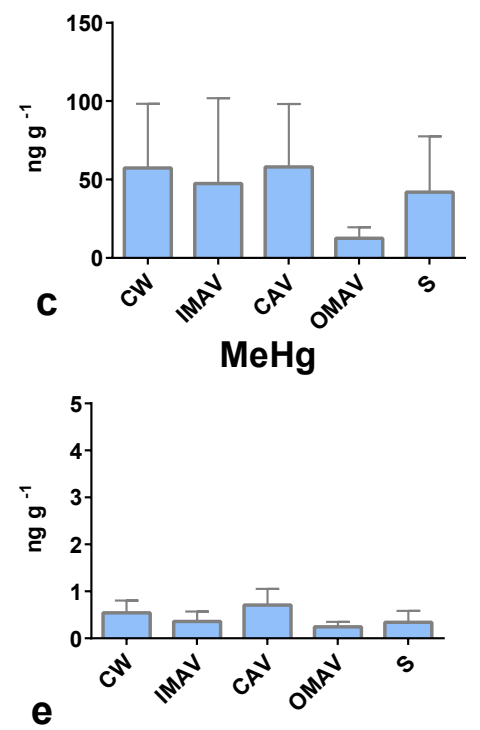

$\% \mathrm{MeHg}$

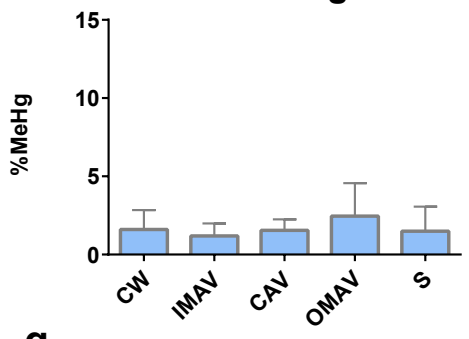

g

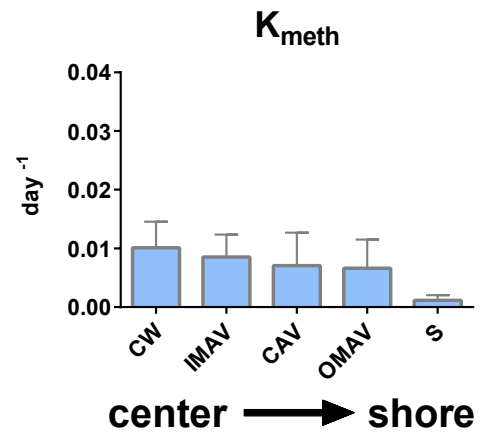

Habitat

b
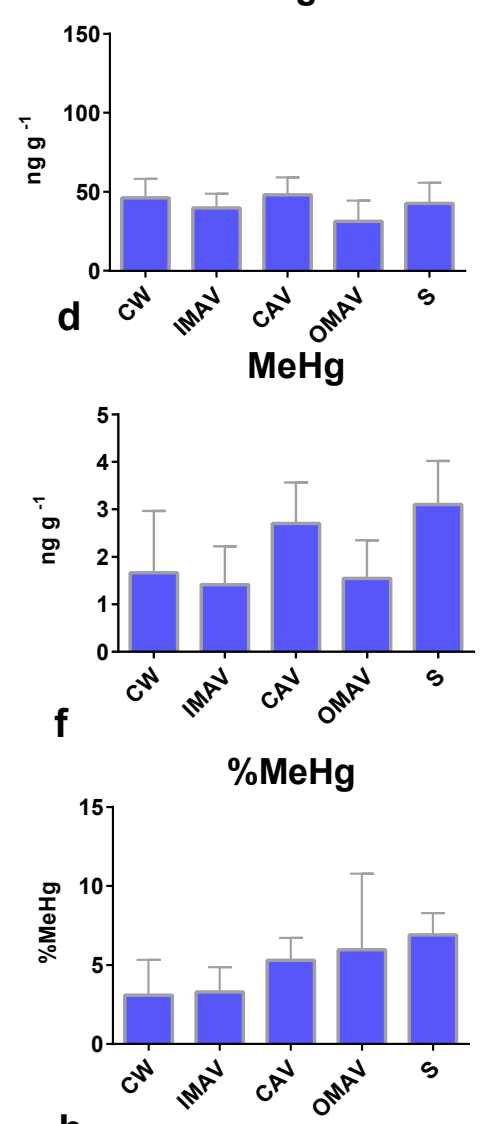

$\mathbf{h}$

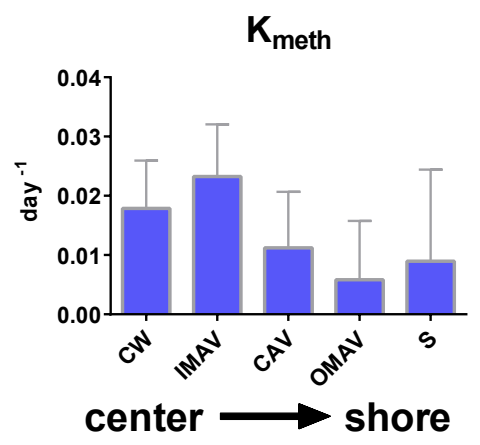

Figure 2.4: Concentrations of sediment inorganic mercury $(\mathrm{IHg})$, sediment methylmercury $(\mathrm{MeHg})$, the percent of sediment total mercury present as methylmercury $(\% \mathrm{MeHg})$, and potential mercury methylation rate constants $\left(\mathrm{K}_{\mathrm{meth}}\right)$ in sediment from stormwater (left) and habitat (right) wetlands, differentiated across ecological zones. Data are presented as mean \pm standard deviation. Abbreviations: $\mathrm{CW}=$ center of wetland, IMAV $=$ inner margin of aquatic vegetation, $\mathrm{CAV}=$ center of aquatic vegetation, $\mathrm{OMAV}=$ outer margin of aquatic vegetation, $\mathrm{S}=$ shore. 


\subsubsection{Relationship of Vegetation to MeHg Biogeochemistry}

Although the wetland sites had wide variations in the biomass and area cover of plants (Figure 2.5), relationships between plant and $\mathrm{Hg}$ variables were weak and inconsistent, suggesting that the presence of aquatic plants did not greatly alter $\mathrm{MeHg}$ biogeochemistry in these artificial wetlands. In concurrence with previous work, which has observed higher $\mathrm{MeHg}$ accumulation in vegetated areas of wetlands (Canário et al., 2007; O'Driscoll et al., 2011; Windham-Myers et al., 2009), we found a weak positive relationship between $\mathrm{MeHg}$ concentrations and both plant biomass and canopy cover in stormwater wetlands (biomass: $\mathrm{p}=0.012, \mathrm{r}=0.57$; canopy cover: $\mathrm{p}$ $=0.034, \mathrm{r}=0.49)$. This effect has been attributed to stimulation of the microbial flora from additional supplies of organic carbon, possibly paired with the concentration of $\mathrm{MeHg}$ as result of evaporative loss of water from sediment (Windham-Myers et al., 2013, 2009). However, our work found no relationship between $\mathrm{K}_{\text {meth }}$ and plant canopy cover or biomass, a link which would be expected if plants stimulated $\mathrm{MeHg}$ production $(\mathrm{p}=0.747$ and 0.910 , respectively). In addition, a marginally significant negative relationship was found between plant canopy cover and $\mathrm{MeHg}$ concentrations in habitat wetlands $(\mathrm{p}=0.052, \mathrm{r}=-0.47)$, similar to the findings of Sinclair et al. (2012) who postulated a reduction in MeHg accumulation as a result of the sediment aeration provided by the radial oxygen loss of plant roots. Our results indicate that any potential concerns about the relationship of aquatic vegetation to $\mathrm{MeHg}$ accumulation are outweighed by the many benefits of plants in surface-flow artificial wetlands (Brix 1997). 

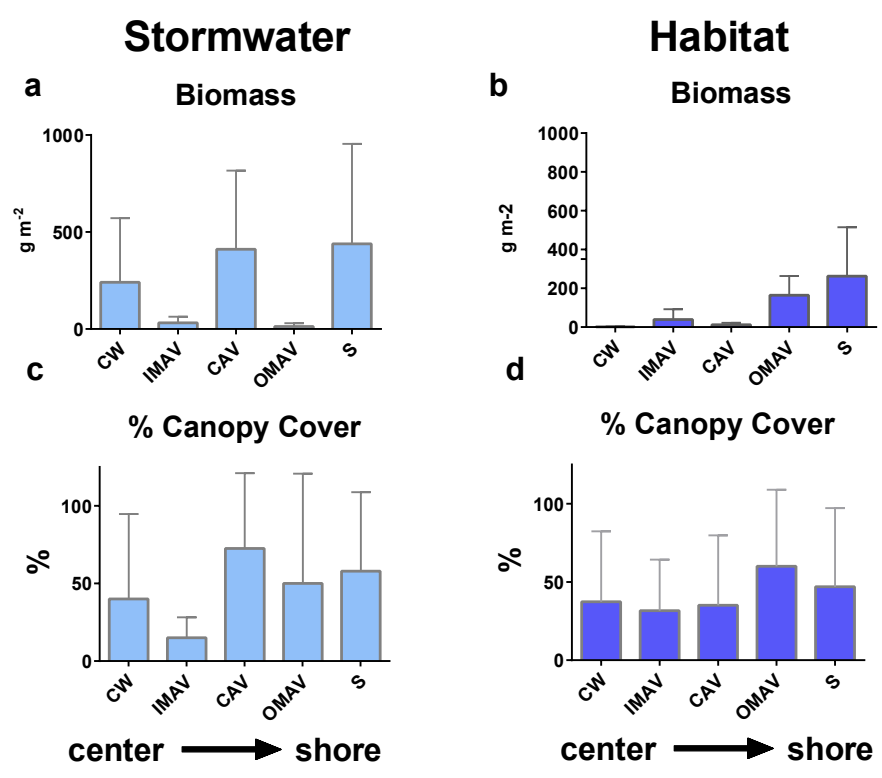

Figure 2.5: Plant biomass (grams dry weight $\mathrm{m}^{-2}$ ) and percent canopy cover in different ecological zones of stormwater (left) and habitat (right) wetlands. Abbreviations: $\mathrm{CW}=$ center of wetland, IMAV = inner margin of aquatic vegetation, $\mathrm{CAV}=$ center of aquatic vegetation, $\mathrm{OMAV}=$ outer margin of aquatic vegetation, $\mathrm{S}=$ shore. Bars display means; error bars represent standard deviation.

\subsubsection{Landscape-scale Implications}

Acute biological risk from $\mathrm{MeHg}$ in individual small stormwater or habitat wetlands is improbable at the concentrations observed, but at the regional or landscape level these wetlands may be important contributors to the $\mathrm{MeHg}$ budget and sources of $\mathrm{MeHg}$ to both aquatic and terrestrial food webs. Small artificial wetlands are poorly inventoried, but may account for up to $20 \%$ of the standing water in the United States alone (Smith et al., 2002), and can be important components of the global biogeochemical cycles of many elements (Downing, 2010). The capacity of these anthropogenic environments to produce $\mathrm{MeHg}$ should be taken into consideration by wetland managers, particularly in areas with pre-existing MeHg contamination issues (Rumbold and Fink, 2006) or in wetlands systems that are sources of fish or insect prey to species of conservation concern, such as loons, otter, little brown bat, rusty blackbird, osprey and others (Edmonds et al., 2012; Little et al., 2015; Scheuhammer et al., 2007). Previous research has linked the relatively high $\mathrm{MeHg}$ accumulation in created habitat wetlands, particularly newly constructed ones, to elevated invertebrate concentrations and possible risk to insectivorous wildlife (Sinclair et al., 2012). While we have not yet made the same links to higher trophic 
levels in stormwater wetlands, the relatively low concentrations of $\mathrm{MeHg}$ in stormwater wetlands suggests a lesser biotic risk. However, given the more hydrologically-connected nature of stormwater wetlands, they are more likely than other created wetland systems to have impacts on downstream ecosystems, indicating the need to quantify the potential of stormwater wetlands as landscape-level sources of MeHg.

\subsubsection{Conclusions}

Our results clearly indicate that both stormwater and habitat wetlands produce and accumulate $\mathrm{MeHg}$ at rates similar to those found in other freshwater systems. The MeHg burdens of these systems are mostly produced in situ, but these wetland types are not "hot spots" of $\mathrm{MeHg}$

production in comparison to some other natural wetlands (Mitchell et al., 2008). Considerable variability does exist between artificial wetland types. Stormwater wetlands accumulate more $\mathrm{THg}$ than habitat wetlands, while converting relatively little to MeHg. This difference is likely related to lower in situ MeHg production in stormwater wetlands, which may in turn be related to important differences in biogeochemistry. In particular, the bioavailable fraction of $\mathrm{IHg}$ is unusually consistent in our studied stormwater wetlands, and the very low organic matter content of younger stormwater wetlands seems to alter their functioning in comparison to natural or habitat wetlands. Spatially, within the wetlands themselves, no significant differences in $\mathrm{MeHg}$ production and accumulation along the terrestrial-aquatic gradient is observed. We suggest that the link between dryout and rewetting cycles, and $\mathrm{MeHg}$ production and accumulation, which has been observed in other systems (Feng et al. 2014), does not occur in these artificial wetland systems during routine water level changes. Although weak positive relationships are found between plants and $\mathrm{MeHg}$ in habitat wetlands, these relationships do not persist between direct measurements of $\mathrm{MeHg}$ production and plant abundance or canopy cover. Overall, the presence of aquatic vegetation likely does not markedly stimulate $\mathrm{MeHg}$ production or accumulation in artificial wetlands.

\subsubsection{Acknowledgments}

The authors would like to gratefully acknowledge Planck (Haiyong) Huang, Talent Huang, and Suman Dhal for field assistance and technical support, as well as Kristine Ciardullo and David Kenth of the City of Brampton, and Steven Thomas and Derek Gray of Pearson International 
Airport for assistance in accessing sites. This project was funded by a Natural Sciences and Engineering Research Council Discovery Grant (Canada).

\subsubsection{References}

Benoit, J. M., Gilmour, C.C., Heyes, A., Mason, R.P., Miller, C.L., 2003. Geochemical and biological controls over methylmercury production and degradation in aquatic ecosystems. ACS Symp. Ser., 835, 262-297

Brix, H., 1997. Do macrophytes play a role in constructed treatment wetlands? Water Sci. Technol. 35, 11-17. doi:10.1016/S0273-1223(97)00047-4

Canário, J., Caetano, M., Vale, C., Cesário, R., 2007. Evidence for elevated production of methylmercury in salt marshes. Environ. Sci. Technol. 41, 7376-7382. doi:10.1021/es071078j

Chavan, P.V., Dennett, K.E., Marchand, E.A., Gustin, M.S., 2007. Evaluation of small-scale constructed wetland for water quality and $\mathrm{Hg}$ transformation. J. Hazard. Mater. 149, 543-547.

Coleman Wasik, J.K., Engstrom, D.R., Mitchell, C.P.J., Swain, E.B., Monson, B.A., Balogh, S.J., Jeremiason, J.D., Branfireun, B.A., Kolka, R.K., Almendinger, J.E., 2015. The effects of hydrologic fluctuation and sulfate regeneration on mercury cycling in an experimental peatland: Drought increases mercury in peatlands. J. Geophys. Res. Biogeosciences 120, 1697-1715. doi:10.1002/2015JG002993

Cosio, C., Flück, R., Regier, N., Slaveykova, V.I., 2014. Effects of macrophytes on the fate of mercury in aquatic systems: Hg and macrophytes. Environ. Toxicol. Chem. 33, 1225-1237. doi:10.1002/etc.2499

Downing, J.A., 2010. Emerging global role of small lakes and ponds: little things mean a lot. Limnetica $29,9-24$.

Drott, A., Lambertsson, L., Björn, E., Skyllberg, U., 2008. Do potential methylation rates reflect accumulated methyl mercury in contaminated sediments? Environ. Sci. Technol. 42, 153-158. doi:10.1021/es0715851

Eckley, C.S., Branfireun, B., 2008. Mercury mobilization in urban stormwater runoff. Sci. Total Environ. 403, 164-177. doi:10.1016/j.scitotenv.2008.05.021

Eckley, C.S., Luxton, T.P., McKernan, J.L., Goetz, J., Goulet, J., 2015. Influence of reservoir water level fluctuations on sediment methylmercury concentrations downstream of the historical Black Butte mercury mine, OR. Appl. Geochem. 61, 284-293. doi:10.1016/j.apgeochem.2015.06.011

Edmonds, S.T., O’Driscoll, N.J., Hillier, N.K., Atwood, J.L., Evers, D.C., 2012. Factors regulating the bioavailability of methylmercury to breeding rusty blackbirds in northeastern wetlands. Environ. Pollut. 171, 148-154. doi:10.1016/j.envpol.2012.07.044 
Elzinga, C.L., Salzer, D.W., Willoughby, J.W., 1998. Measuring \& Monitoring Plant Populations. United States Bureau of Land Management Technical Reference 1730-1 BLM/RS/ST-98/005+1730.

Feng, S., Ai, Z., Zheng, S., Gu, B., Li, Y., 2014. Effects of dryout and inflow water quality on mercury methylation in a constructed wetland. Water Air Soil Pollut. 225. doi:10.1007/s11270-014-1929-6

Galloway, M., Branfireun, B., 2004. Mercury dynamics of a temperate forested wetland. Sci. Total Environ. 325, 239-254. doi:10.1016/j.scitotenv.2003.11.010

Gilmour, C.C., Podar, M., Bullock, A.L., Graham, A.M., Brown, S.D., Somenahally, A.C., Johs, A., Hurt, R.A., Bailey, K.L., Elias, D.A., 2013. Mercury methylation by novel microorganisms from new environments. Environ. Sci. Technol. 47, 11810-11820. doi:10.1021/es403075t

Goulet, R.R., Holmes, J., Page, B., Poissant, L., Siciliano, S.D., Lean, D.R.S., Wang, F., Amyot, M., Tessier, A., 2007. Mercury transformations and fluxes in sediments of a riverine wetland. Geochim. Cosmochim. Acta 71, 3393-3406. doi:10.1016/j.gca.2007.04.032

Hall, B.D., Aiken, G.R., Krabbenhoft, D.P., Marvin-DiPasquale, M., Swarzenski, C.M., 2008. Wetlands as principal zones of methylmercury production in southern Louisiana and the Gulf of Mexico region. Environ. Pollut. 154, 124-134. doi:10.1016/j.envpol.2007.12.017

Hall, B.D., Louis, V.L.S., Rolfhus, K.R., Bodaly, R.A., Beaty, K.G., Paterson, M.J., Cherewyk, K.A.P., 2005. Impacts of reservoir creation on the biogeochemical cycling of methyl mercury and total mercury in boreal upland forests. Ecosystems 8, 248-266. doi:10.1007/s10021-003-0094-3

Hammer, D.A. 1992. Creating Freshwater Wetlands. Lewis Publishers, Boca Raton.

Hintelmann, H., Evans, R.D., 1997. Application of stable isotopes in environmental tracer studies Measurement of monomethylmercury $\left(\mathrm{CH}_{3} \mathrm{Hg}^{+}\right)$by isotope dilution ICP-MS and detection of species transformation. Fresenius J. Anal. Chem. 358, 378-385. doi:10.1007/s002160050433

Hintelmann, H., Keppel-Jones, K., Evans, R.D., 2000. Constants of mercury methylation and demethylation rates in sediments and comparison of tracer and ambient mercury availability. Environ. Toxicol. Chem. 19, 2204-2211.

Hintelmann, H., Ogrinc, N. 2003. Determination of stable mercury isotopes by ICP/MS and their application in environmental studies. ACS Symp. Ser., 835, 321-338.

Hoggarth, C.G.J., Hall, B.D., Mitchell, C.P.J., 2015. Mercury methylation in high and low-sulfate impacted wetland ponds within the prairie pothole region of North America. Environ. Pollut. 205, 269-277. doi:10.1016/j.envpol.2015.05.046

Horvat, M.; Bloom, N.S.; Liang, L., 1993. Comparison of distillation with other current isolation methods for the determination of methyl mercury compounds in low level environmental samples. Part 1. Sediments. Anal. Chim. Acta. 281, 135-152. 
Hsu-Kim, H., Kucharzyk, K.H., Zhang, T., Deshusses, M.A., 2013. Mechanisms regulating mercury bioavailability for methylating microorganisms in the aquatic environment: A critical review. Environ. Sci. Technol. 47, 2441-2456. doi:10.1021/es304370g

Jacob, D.L., Otte, M.L., 2003. Conflicting processes in the wetland plant rhizosphere: Metal retention or mobilization? Water Air Soil Pollut. Focus 3, 91-104.

Kadlec, R.H., Wallace, S. 2009. Treatment Wetlands, second ed. CRC Press, Taylor \& Francis Publishing, New York.

Li, Y., Cai, Y., 2012. Progress in the study of mercury methylation and demethylation in aquatic environments. Chin. Sci. Bull. 58, 177-185. doi:10.1007/s11434-012-5416-4

Little, M.E., Burgess, N.M., Broders, H.G., Campbell, L.M., 2015. Mercury in little brown bat (Myotis lucifugus) maternity colonies and its correlation with freshwater acidity in Nova Scotia, Canada. Environ. Sci. Technol. 49, 2059-2065. doi:10.1021/es5050375

Mailman, M., Stepnuk, L., Cicek, N., Bodaly, R.A., 2006. Strategies to lower methyl mercury concentrations in hydroelectric reservoirs and lakes: A review. Sci. Total Environ. 368, 224-235. doi:10.1016/j.scitotenv.2005.09.041

Marvin-DiPasquale, M., Windham-Myers, L., Agee, J.L., Kakouros, E., Kieu, L.H., Fleck, J.A., Alpers, C.N., Stricker, C.A., 2014. Methylmercury production in sediment from agricultural and nonagricultural wetlands in the Yolo Bypass, California, USA. Sci. Total Environ. 484, 288-299. doi:10.1016/j.scitotenv.2013.09.098

McCord, S.A., Heim, W.A., 2015. Identification and prioritization of management practices to reduce methylmercury exports from wetlands and irrigated agricultural lands. Environ. Manage. 55, 725-740. doi:10.1007/s00267-014-0425-5

Meng, B., Feng, X., Qiu, G., Li, Z., Yao, H., Shang, L., Yan, H., 2016. The impacts of organic matter on the distribution and methylation of mercury in a hydroelectric reservoir in Wujiang River, Southwest China: The influence of organic matter on mercury cycling. Environ. Toxicol. Chem. 35, 191-199. doi:10.1002/etc.3181

Mergler, D., Anderson, H.A., Chan, L.H.M., Mahaffey, K.R., Murray, M., Sakamoto, M., Stern, A.H., 2007. Methylmercury exposure and health effects in humans: A worldwide concern. AMBIO 36, 3-11. doi:10.1579/0044-7447(2007)36[3:MEAHEI]2.0.CO;2

Mitchell, C.P.J., Branfireun, B.A., Kolka, R.K., 2008. Spatial characteristics of net methylmercury production hot spots in peatlands. Environ. Sci. Technol. 42, 1010-1016. doi:10.1021/es0704986

Munthe, J., Bodaly, R.A., Branfireun, B.A., Driscoll, C.T., Gilmour, C.C., Harris, R., Horvat, M., Lucotte, M., Malm, O., 2007. Recovery of mercury-contaminated fisheries. AMBIO 36, 33-44. doi:10.1579/0044-7447(2007)36[33:ROMF]2.0.CO;2 
O’Driscoll, N.J., Canário, J., Crowell, N., Webster, T., 2011. Mercury speciation and distribution in coastal wetlands and tidal mudflats: relationships with sulphur speciation and organic carbon. Water Air Soil Pollut. 220, 313-326. doi:10.1007/s11270-011-0756-2

Ontario Ministry of the Environment, 2003. Stormwater management planning and design manual. MOE, Toronto, Ont.

Oswald, C.J., Carey, S.K., 2016. Total and methyl mercury concentrations in sediment and water of a constructed wetland in the Athabasca Oil Sands Region. Environ. Pollut. 213, 628-637. doi:10.1016/j.envpol.2016.03.002

Podar, M., Gilmour, C.C., Brandt, C.C., Soren, A., Brown, S.D., Crable, B.R., Palumbo, A.V., Somenahally, A.C., Elias, D.A., 2015. Global prevalence and distribution of genes and microorganisms involved in mercury methylation. Sci. Adv. 1, e1500675-e1500675. doi:10.1126/sciadv.1500675

R Core Team (2016). R: A language and environment for statistical computing. R Foundation for Statistical Computing, Vienna, Austria. URL https://www.R-project.org/.

Ravichandran, M., 2004. Interactions between mercury and dissolved organic matter-a review. Chemosphere 55, 319-331. doi:10.1016/j.chemosphere.2003.11.011

Roy, V., Amyot, M., Carignan, R., 2009. Beaver ponds increase methylmercury concentrations in Canadian Shield streams along vegetation and pond-age gradients. Environ. Sci. Technol. 43, 5605-5611. doi:10.1021/es901193x

Rumbold, D.G., Fink, L.E., 2006. Extreme spatial variability and unprecedented methylmercury concentrations within a constructed wetland. Environ. Monit. Assess. 112, 115-135.

Scheuhammer, A.M., Meyer, M.W., Sandheinrich, M.B., Murray, M.W., 2007. Effects of environmental methylmercury on the health of wild birds, mammals, and fish. AMBIO 36, 12-19.

Scholz, M., Lee, B., 2005. Constructed wetlands: a review. Int. J. Environ. Stud. 62, 421-447. doi:10.1080/00207230500119783

Sinclair, K.A., Xie, Q., Mitchell, C.P.J., 2012. Methylmercury in water, sediment, and invertebrates in created wetlands of Rouge Park, Toronto, Canada. Environ. Pollut. 171, 207-215. doi:10.1016/j.envpol.2012.07.043

Smith, S.V., Renwick, W.H., Bartley, J.D., Buddemeier, R.W., 2002. Distribution and significance of small, artificial water bodies across the United States landscape. Sci. Total Environ. 299, 21-36.

Stamenkovic, J., Gustin, M.S., Dennett, K.E., 2005. Net methyl mercury production versus water quality improvement in constructed wetlands: trade-offs in pollution control. Wetlands 25, 748-757. 
St. Louis, V.L., Rudd, J.W., Kelly, C.A., Beaty, K.G., Bloom, N.S., Flett, R.J., 1994. Importance of wetlands as sources of methyl mercury to boreal forest ecosystems. Can. J. Fish. Aquat. Sci. 51, 1065-1076.

St.Louis, V.L., Rudd, J.W.M., Kelly, C.A., Bodaly, R.A., Paterson, M.J., Beaty, K.G., Hesslein, R.H., Heyes, A., Majewski, A.R., 2004. The rise and fall of mercury methylation in an experimental reservoir. Environ. Sci. Technol. 38, 1348-1358. doi:10.1021/es034424f

Tjerngren, I., Karlsson, T., Björn, E., Skyllberg, U., 2011. Potential Hg methylation and MeHg demethylation rates related to the nutrient status of different boreal wetlands. Biogeochemistry 108, 335-350. doi:10.1007/s10533-011-9603-1

Ullrich, S.M., Tanton, T.W., Abdrashitova, S.A., 2001. Mercury in the aquatic environment: A review of factors affecting methylation. Crit. Rev. Environ. Sci. Technol. 31, 241-293.

doi:10.1080/20016491089226

Windham-Myers, L., Marvin-DiPasquale, M., Kakouros, E., Agee, J.L., Kieu, L.H., Stricker, C.A., Fleck, J.A., Ackerman, J.T., 2013. Mercury cycling in agricultural and managed wetlands of California, USA: Seasonal influences of vegetation on mercury methylation, storage, and transport. Sci.

Total Environ. doi:10.1016/j.scitotenv.2013.05.027

Windham-Myers, L., Marvin-Dipasquale, M., Krabbenhoft, D.P., Agee, J.L., Cox, M.H., HerediaMiddleton, P., Coates, C., Kakouros, E., 2009. Experimental removal of wetland emergent vegetation leads to decreased methylmercury production in surface sediment. J. Geophys. Res. 114. doi:10.1029/2008JG000815

Woodcock, T.S., Monaghan, M.C., Alexander, K.E., 2010. Ecosystem characteristics and summer secondary production in stormwater ponds and reference wetlands. Wetlands 30, 461-474. doi:10.1007/s13157-010-0057-3 


\section{Chapter 3}

Mercury methylation in stormwater wetlands at different stages in the management lifecycle 


\subsection{Abstract}

Stormwater wetlands effectively manage erosion, flooding, and pollutant loadings, but are also sources of methylmercury $(\mathrm{MeHg})$, a bioaccumulative neurotoxin which is produced by anaerobic aquatic microorganisms. Stormwater wetlands are managed structures with a 10-15 year working life, after which they are dredged and reflooded. However, the relationship of the wetland's chronological position in this management lifecycle to $\mathrm{MeHg}$ production is unknown. In this study, I measured $\mathrm{MeHg}$ and inorganic mercury ( $\mathrm{IHg})$ concentrations, and the potential for $\mathrm{MeHg}$ formation $\left(\mathrm{K}_{\mathrm{meth}}\right)$, in the sediments of new, mature, and recently dredged stormwater wetlands. In each wetland, these variables and a range of ancillary biogeochemical properties were assessed at two zones within each wetland during the early summer, peak summer, and fall of 2013. Methylmercury concentrations in stormwater wetlands appear to be driven by mercury methylation, rather than demethylation, indicated by significant correlations between $\mathrm{K}_{\text {meth }}$ values and $\mathrm{MeHg}$ concentrations and the percent of mercury $(\mathrm{Hg})$ present as $\mathrm{MeHg}$. Relationships between $\mathrm{Hg}$ variables and ancillary biogeochemistry reveals that $\mathrm{Hg}$ methylation is carried out by sulfate reducing bacteria in these stormwater wetlands, but that the process is modulated by the supply of IHg substrate, sediment total and labile organic carbon, and competition with nitrate reducers. Wetlands at different points in the management lifecycle differ in terms of their MeHg biogeochemistry. The organic matter-poor new wetland had low $\mathrm{MeHg}$ production (mean $0.014 \mathrm{day}^{-1}$ ) and accumulation (mean $0.015 \mathrm{ng} \mathrm{g}^{-1}$ ), while the mature wetland both produced and accumulated $\mathrm{MeHg}$ about five times more actively. Dredging only temporarily reduces the $\mathrm{MeHg}$ production capacity of the sediments, while increasing the spatial variability of $\mathrm{MeHg}$ production. I speculate that these effects are linked to heterogeneity in the extent of the dredging process. Pockets of undredged sediment allowed the rapid recolonization of the reflooded sediments by mercury methylators, based on rapid increases in $\mathrm{K}_{\text {meth }}$ values from very low (mean 0.015 day $^{-1}$ ) immediately after dredging, to values similar to those in the mature wetland after five months. Reoxidation of sulfides to sulfates when sediments were exposed to air during the dredging process stimulated the metabolism of sulfate-reducing mercury methylators and created further heterogeneity in $\mathrm{MeHg}$ production. Additional studies should focus on the effects of dredging on the microbial ecology and biogeochemistry of $\mathrm{MeHg}$, and other important elements, in stormwater wetlands. 


\subsection{Introduction}

Stormwater wetlands are created environments which effectively manage erosion, flooding, and pollutant loadings, while also providing wildlife habitat and aesthetic benefits (Malaviya and Singh, 2012). These installations are an increasingly common water management strategy in urban and suburban landscapes (Scholz and Lee, 2005; Smith et al., 2002). Unfortunately, in common with other artificial wetlands, stormwater wetlands also produce methylmercury (MeHg), a bioaccumulative neurotoxin (Chapter 2). In previous work, I found that stormwater wetlands accumulated less MeHg than wetlands managed for habitat provision (Chapter 2), a pattern that appeared to be related to fundamental differences in the mercury $(\mathrm{Hg})$ biogeochemistry of these environments leading to lower in situ MeHg production.

In freshwater environments, $\mathrm{MeHg}$ is produced by several taxonomic groups of anaerobic aquatic microorganisms, including members of the sulfate reducers, iron reducers, and methanogens (Gilmour et al., 2013; Podar et al., 2015), and degraded by both biotic and abiotic demethylation processes (Lin et al., 2012), with the net MeHg accumulation capacity of a wetland integrating the balance between methylation and demethylation. The biogeochemical drivers of net $\mathrm{MeHg}$ accumulation are complex, and include the supply of bioavailable inorganic mercury $(\mathrm{IHg})$ and metabolic substrates for mercury $(\mathrm{Hg})$ methylating microbes, the quantity and quality of sediment and dissolved organic carbon, $\mathrm{pH}$, temperature and redox status (Hsu-Kim et al., 2013; Munthe et al., 2007; Ravichandran, 2004; Tjerngren et al., 2011). The relative importance of these drivers of $\mathrm{MeHg}$ biogeochemistry varies among different environments (Lehnherr et al., 2012; Little et al., 2015; Mitchell and Gilmour, 2008). Detailed biogeochemical investigations are therefore required for a functional understanding of MeHg biogeochemistry in stormwater wetlands. This understanding is critical for guiding practical design strategies that further lessen MeHg production and accumulation, as well as to reduce the impact of stormwater wetlands as sources of $\mathrm{MeHg}$ to downstream ecosystems.

The management status of a stormwater wetland may have important implications for its $\mathrm{MeHg}$ biogeochemistry. Stormwater wetlands differ fundamentally from other types of wetlands because they have a defined, management driven lifecycle, which lasts from five to fifteen years. After initial construction, often within or nearby residential developments, stormwater wetlands 
passively trap sediment and debris, along with metals and other contaminants. Eventually, sediment must be removed to maintain the original design depth and functioning of the wetland. In this process, the wetland is drained, and sediment is removed and disposed off-site. After dredging, mulch is added to provide organic matter, and the wetland is reflooded and allowed to revegetate naturally (Drake and Guo 2008; Ontario Ministry of the Environment, 2003). Dredging has a strong potential to impact the $\mathrm{MeHg}$ dynamics of a stormwater wetland. Although moderate fluctuations in water level do not appear to affect $\mathrm{MeHg}$ in stormwater wetlands (Chapter 2), existing research has suggested that extreme dryout events followed by flooding may stimulate MeHg production and accumulation (Feng et al., 2014; Oswald and Carey, 2016), likely due to aerobic regeneration of electron acceptors, such as sulfate, which stimulates mercury methylating microbes (Coleman Wasik et al., 2012, 2015). This suggests that the overall dredging process may stimulate $\mathrm{MeHg}$ production. Alternatively, the removal of sediment and associated microflora, as well accumulated inorganic mercury (IHg), may result in decreased MeHg production.

Important differences may also exist between wetlands at the beginning and end of the management life cycle. Unlike other wetlands, where $\mathrm{MeHg}$ production and accumulation is high in young wetlands and declines with age (Roy et al., 2009; Sinclair et al., 2012), I have previously observed a positive relationship between $\mathrm{MeHg}$ concentrations and stormwater wetland age (Chapter 2), which may be related to lower organic matter content in new stormwater wetlands. However, this pattern could also be explained by any number of other factors that were not assessed in the preliminary explorations presented in Chapter 2. Overall, a better understanding of the relationship between management stage and $\mathrm{MeHg}$ biogeochemistry may help reduce $\mathrm{MeHg}$ accumulation and impacts on sensitive species, for instance through timing of dredging events, but no information exists as to how $\mathrm{MeHg}$ biogeochemistry may differ between stormwater wetlands at different stages in the management lifecycle.

Marked spatial variability in MeHg production and net accumulation has been observed in other wetlands (Mitchell et al., 2008) and may occur in stormwater wetlands as well, possibly driven by links to the spatial variability in plant cover. In Chapter 2, mercury methylation rate constants $\left(\mathrm{K}_{\text {meth }}\right)$ in stormwater wetlands showed nonsignificant decreases from the shore to the center of the wetland. This pattern may have related to the presence of emergent aquatic vegetation, which 
is usually abundant at the littoral margin of the wetland and sparse or absent in the pelagic area. Although emergent aquatic vegetation contributes to the functioning of stormwater wetlands, (Brix, 1997) it can also increase $\mathrm{MeHg}$ production and accumulation by several orders of magnitude in some wetlands (Regier et al. 2012; Valega et al. 2008; Windham-Myers et al., 2009). In Chapter 2, the importance of aquatic vegetation to $\mathrm{MeHg}$ production in stormwater wetlands was ambiguous. While a moderately significant positive correlation was found between plant canopy cover and biomass and $\mathrm{MeHg}$ concentrations, there was no relationship between $\mathrm{K}_{\text {meth }}$ and plant variables, a relationship that would be expected if plants stimulate mercury methylation via the release of labile organic carbon (Windham-Myers et al., 2014). Given the potential importance of plants to fine-scale variation in $\mathrm{MeHg}$ biogeochemistry, and the inconclusive results obtained in previous work, there is a need for a more detailed investigation of the relationship between the presence and activity of plants, and $\mathrm{MeHg}$ production and accumulation in stormwater wetlands.

The primary purpose of this study was to explore $\mathrm{MeHg}$ biogeochemistry in stormwater wetlands at different stages in the wetland management lifecycle, and to identify key controls on $\mathrm{MeHg}$ production in stormwater wetlands. Additionally, I assessed the possibility of fine-scale spatial variation in $\mathrm{MeHg}$ production and concentrations in stormwater wetlands, and aimed to determine more conclusively whether plants affect $\mathrm{MeHg}$ production in stormwater wetlands. To answer these questions, I conducted detailed biogeochemical surveys over the growing season in vegetated and unvegetated zones of a new, a mature, and a recently dredged stormwater wetland.

\subsection{Methods}

\subsubsection{Experimental Design}

In order to better understand $\mathrm{MeHg}$ production and accumulation in stormwater wetlands, I carried out detailed biogeochemical investigations of a new, a dredged, and a mature stormwater wetland, all located in the City of Brampton, in southern Ontario $\left(43^{\circ} 43^{\prime} \mathrm{N}, 79^{\circ} 45^{\prime} \mathrm{W}\right)$. Within each wetland, I collected data from two zones, a shallow-water littoral area at the margin of the wetland, and a deeper water, pelagic area. In order to track changes in wetland $\mathrm{Hg}$ biogeochemistry over the course of the growing season, each wetland was sampled in early summer (late June-early July), peak summer (August), and fall (late October-early November). 
To provide replication within each zone, three subsites were sampled within four meters of one another. Based on previous findings of the importance of upper layers of submerged sediments to MeHg cycling (Goulet et al., 2007), analyses focused on the sediment and porewaters. For each subsite, the depth at which samples were collected (referred to as the analytical depth) was determined by the depth to which plant roots extended. If no plants were present, samples were collected from the top two centimeters of the sediment profile. Each zone was assessed for a range of $\mathrm{Hg}$ and ancillary biogeochemical variables, including enriched stable mercury isotopebased assays of mercury methylation potential (Hintelmann et al., 2000). In vegetated sites, the relationship of $\mathrm{MeHg}$ biogeochemistry to the presence of aquatic plants was assessed by collecting sediment cores with rooted plants in situ, measuring aboveground and belowground biomass, and estimating the release of organic carbon from roots.

\subsubsection{Site Description}

Three stormwater wetlands were surveyed. All sites had a permanent pool of standing water, and received runoff from suburban housing. The first, a new stormwater wetland, had been constructed as part of a housing development approximately six months before sampling began and was hydrologically functional, but unvegetated (coordinates at $43^{\circ} 45^{\prime} 17.0^{\prime \prime} \mathrm{N}$, $79^{\circ} 47^{\prime} 03.5^{\prime \prime} \mathrm{W}$ ) This site was a large two-bay wetland system receiving construction as well as suburban runoff. Samples were collected from the smaller bay, which nearest the outflow pipe and had an area of approximately 1.28 ha. The second, fully mature wetland was fifteen years old at the time of sampling, 0.477 ha in size, and vegetated with typical emergent vegetation, dominated by Typha latifolia (cattail) $\left(43^{\circ} 46^{\prime} 41.1^{\prime \prime} \mathrm{N}, 79^{\circ} 43^{\prime} 34.3^{\prime \prime} \mathrm{W}\right.$,). The third site, located at $43^{\circ} 42^{\prime} 15.7^{\prime \prime} \mathrm{N}, 79^{\circ} 46^{\prime} 42.4^{\prime \prime} \mathrm{W}$, was also fifteen years old, but had recently been dredged to remove accumulated sediment and improve function. In this process, water was diverted, and accumulated sediment and debris were removed, leaving the clay liner intact. Shredded bark mulch was added as an organic substrate, and the system was reflooded and allowed to naturally revegetate (David Kenth, personal communication). No vegetation was present in the dredged wetland at the beginning of sampling. This wetland was also part of a larger multibay system (total area of $0.5 \mathrm{ha}$ ), with samples collected from the final bay nearest the outflow (area of 0.053 ha). The other bays in the complex had not been dredged. Based on observations of similar sites, 
I predicted that the new and the dredged wetlands, which were unvegetated at the start of the study, would develop emergent aquatic vegetation over the course of the project.

\subsubsection{Sample Collection}

Samples were collected from three subsites in the littoral and pelagic zones of each wetland once during each season. At each subsite, multiple cores were collected using $4.7 \mathrm{~cm}$ inner diameter transparent polycarbonate sediment core tubes, stored on ice in coolers, and transported upright to the University of Toronto Scarborough, where they were either processed immediately, or stored at $4^{\circ} \mathrm{C}$ until processing within 48 hours.

Mercury variables (total mercury, $\mathrm{THg}$; inorganic mercury, $\mathrm{IHg}$; $\mathrm{MeHg}$; percent of mercury present as $\mathrm{MeHg}, \% \mathrm{MeHg}$; and potential methylation rate constant, $\mathrm{K}_{\text {meth }}$ ) and sediment nutrient analyses (sediment nitrate and ammonia) were obtained from the same sediment core (mercury/nutrient core). In vegetated subsites, a living, rooted cattail plant was maintained in the sediment/nutrient core for the duration of the methylation rate incubation. To assess the rate at which $\mathrm{IHg}$ was transformed to $\mathrm{MeHg}$, isotopically enriched inorganic ${ }^{200} \mathrm{Hg}$ was added to these sediment/nutrient cores and the production of isotopically enriched $\mathrm{Me}^{200} \mathrm{Hg}$ was followed, enabling the calculation of potential methylation rate constants $\left(\mathrm{K}_{\text {meth }}\right)$, using the methods and calculations described by Hintelmann \& Evans (1997). It should be emphasized that $\mathrm{K}_{\text {meth }}$ is calculated based on the methylation of newly added isotopic $\mathrm{Hg}(\mathrm{II})$, which is more bioavailable to methylating microbes than ambient $\mathrm{Hg}$ (Hintelmann et al., 2000). Methylation rate constants therefore estimate the potential, rather than the actual, ability of the microbial community to methylate $\mathrm{Hg}$. To introduce the enriched $\mathrm{Hg}$ isotope to the sediment cores, a $94.3 \%$ enriched ${ }^{200} \mathrm{HgCl}$ solution was diluted in site water, which had been previously passed through a $0.2 \mu \mathrm{m}$ glass filter to produce a final $\mathrm{Hg}$ concentration of $12 \mu \mathrm{g} \mathrm{ml}^{-1}$. After an hour of equilibration, a gastight syringe was used to inject this solution into the core through silicon-covered septa spaced at $1-\mathrm{cm}$ intervals, yielding an "excess" ${ }^{200} \mathrm{Hg}$ concentration in the sediment that approximately matched the estimated background ambient THg levels in these sites (Sinclair et al., 2012; Chapter 2). To allow the plants in vegetated cores to maintain metabolic activity, the aboveground parts of rooted plants were illuminated under fluorescent grow lights. The sediment cores themselves were wrapped in black plastic to shield them from light, and incubated at $22{ }^{\circ} \mathrm{C}$ 
for 19 hours. At the conclusion of the incubations, cores were extruded and sediment samples collected from the surface of the core to the analytical depth of that subsite. In vegetated cores, plant root biomass was gently separated from sediment, leaving the plant intact. Subsequent analyses using these plant parts are described in Section 4.3.6. All sediments were homogenized thoroughly, and 30-40 g samples collected for the analysis of sediment nutrients (nitrate and ammonia) and $\mathrm{Hg}$ variables. These samples were stored at $-20^{\circ} \mathrm{C}$ until analysis.

Separate sediment cores were collected for assessing physical variables (organic matter content, volumetric moisture content, and bulk density), and for $0.5 \mathrm{~N} \mathrm{HCl}$ extractable iron content. Sediment cores for physical variables were processed on the bench, while cores for iron analyses were extruded, sectioned to the appropriate analytical depth and homogenized in an anaerobic chamber under a $\mathrm{N}_{2}$ atmosphere. A 30-40 g sample of this homogenized sediment was collected in the glovebox, sealed in a small Ziploc bag, and kept frozen at $-20^{\circ} \mathrm{C}$ until analysis. To obtain sufficient porewater for analyses, cores from each subsite (at least $n=3$ ) were pooled to yield one sample per position. These cores were transferred to an anaerobic chamber, where overlying water was discarded. The core was extruded to the appropriate analytical depth for that subsite, and homogenized. Porewater was vacuum-extracted from this sediment through acidwashed $0.45-\mu \mathrm{m}$ filters. Porewater samples were collected for dissolved organic carbon measurement, and major anion analysis, and stored in the dark at $4^{\circ} \mathrm{C}$ until analysis.

\subsubsection{Sediment Laboratory Analyses}

\subsubsection{Iron}

Sediment concentrations of $0.5 \mathrm{~N} \mathrm{HCl}$-extractable Fe(II) were assessed by complexation with ferrozine-hepes and measurement of the absorbance at $562 \mathrm{~nm}$ on a UV spectrophotometer. Reduction of all iron present with hydroxylamine allowed the subsequent quantification of total $\mathrm{Fe}$, with the difference between total $\mathrm{Fe}$ and $\mathrm{Fe}(\mathrm{II})$ attributable to $\mathrm{Fe}(\mathrm{III})$ concentrations (Viollier et al., 2000). 


\subsubsection{Sediment Nutrients}

Sediments for nitrate and ammonia analysis were extracted in $30 \mathrm{ml} 2 \mathrm{M} \mathrm{KCl}$, agitated at 130 rpm for thirty minutes, and filtered through Whatman No. 2 filter paper. Following extraction, sediment nitrate-N and ammonia-N were assessed colorimetrically using a Lachat QuickChem 8500 flow injection autoanalyzer.

\subsubsection{Physical Parameters}

Moisture content, bulk density, and organic matter were determined from one core at both zones in each wetland per season. Sediment core lengths were measured and the volume calculated using the known dimensions of the coring tube. Sediment water content was assessed by drying cores for $24 \mathrm{~h}$ at $105^{\circ} \mathrm{C}$, and bulk density calculated as the quotient of dry sediment mass and sediment volume. Moisture content was calculated volumetrically, which also provided a measurement of porosity in these saturated sediments. The organic matter (OM) content of the core, expressed as a percentage of the dry sediment mass, was then determined using the loss-onignition method by ashing at $550^{\circ} \mathrm{C}$ for four hours.

\subsubsection{THg and MeHg Quantification}

Total mercury (THg) and $\mathrm{MeHg}$ concentrations were assessed in sediment samples. Methylmercury concentrations were determined using isotope dilution-gas chromatographyinductively coupled plasma mass spectrometry (ID-GC-ICPMS) (Hintelmann and Evans 1997, Hintelmann and Ogrinc 2003). In brief, sediment samples were spiked with a known concentration of $\mathrm{Me}^{199} \mathrm{Hg}$ as an internal standard, and distilled using a similar method to that described by Horvat et al. (1993) in $8 \mathrm{M} \mathrm{H}_{2} \mathrm{SO}_{4}$ and $20 \% \mathrm{KCl}$. Acid-cleaned Teflon vessels were used for the distillations. All mercury species, inclusive of $\mathrm{MeHg}$, were ethylated with sodium tetraethylborate, purged from solution by bubbling with high-purity nitrogen, and concentrated into a glass trap filled with Tenax ${ }^{\circledR}$. The mercury held in these traps was thermally desorbed into a stream of mercury-free argon gas, separated in a chromatographic column, and introduced directly to an Agilent 7700x ICP-MS. Isotope ratios and the concentration of the internal $\mathrm{Me}^{199} \mathrm{Hg}$ standard were used to determine the concentrations of both ambient $\mathrm{MeHg}$, and newly formed "excess" $\mathrm{Me}^{200} \mathrm{Hg}$ (that which is attributable to the added enriched isotope). This 
approach, and detailed calculations are described by Hintelmann and Evans (1997). The calculation method of Drott et al. (2008) was used to determine $\mathrm{K}_{\text {meth }}$ values for each sample.

To measure THg concentrations, samples were lyophilized until stable mass was achieved, homogenized, and 0.2-0.3 g of sediment was analyzed by nitric acid digestion until vapors became colorless. Total mercury digestates were diluted with deionized water and oxidized with $0.5 \mathrm{ml} \mathrm{BrCl}$, followed by automated reduction via $\mathrm{SnCl}_{2}$ reaction, capture on dual gold traps, and thermal desorption with a Tekran $2600 \mathrm{Hg}$ analyzer. Hg gas was delivered directly into the ICPMS instrument in a stream of argon gas, and individual isotopes were distinguished and quantified. Inorganic $\mathrm{Hg}$ in each sample was estimated as $\mathrm{THg}$ concentration minus $\mathrm{MeHg}$ concentration.

Quality control of mercury determinations was assessed through the use of blanks, duplicate samples, certified reference materials (MESS-3 for THg; ERM CC580 for MeHg sediment samples, Dorm-3 for MeHg invertebrate samples) and matrix spikes (THg only). Method detection limits were calculated as three times the standard deviation of blank results. Blank concentrations were assessed using the average mass of sample digested. Limits of detection for $\mathrm{K}_{\text {meth }}$ were determined on a per-sample basis using the calculation method of Hintelmann et al. 1997, and represented the minimum $\mathrm{Me}^{201} \mathrm{Hg}$ concentration that allowed the newly formed $\mathrm{Me}^{201} \mathrm{Hg}$ to be distinguished from that naturally present. These data can be found in Table 3.1.

Table 3.1: Quality control data for $\mathrm{MeHg}$ and $\mathrm{THg}$ determinations

\begin{tabular}{|c|c|c|c|c|c|}
\hline & $\begin{array}{c}\text { Ambient MeHg } \\
\text { (based on } \\
\mathrm{Me}^{202} \mathrm{Hg} \text { ) }\end{array}$ & $\mathrm{Me}^{200} \mathrm{Hg}$ & $\mathrm{K}_{\text {meth }}$ & $\begin{array}{c}\text { Ambient } \mathrm{THg} \\
\text { (based on } \\
\mathrm{T}^{202} \mathrm{Hg} \text { ) } \\
\end{array}$ & $\mathrm{T}^{200} \mathrm{Hg}$ \\
\hline $\begin{array}{c}\text { Certified reference } \\
\text { material }\end{array}$ & CC580 & & & MESS-3 & \\
\hline $\begin{array}{l}\text { CRM average } \\
\text { recovery }(\%)\end{array}$ & $\begin{array}{c}94.4 \pm 13.1 \\
(n=14)\end{array}$ & & & $\begin{array}{c}101.4 \pm 6.9 \\
(n=7)\end{array}$ & \\
\hline $\begin{array}{l}\text { Average duplicate } \\
\text { RSD }(\%)\end{array}$ & $\begin{array}{c}5.3 \pm 6.0 \\
(n=12 \text { pairs })\end{array}$ & $\begin{array}{c}7.9 \pm 6.3 \\
(n=9 \text { pairs })\end{array}$ & & $\begin{array}{c}4.1 \pm 5.2 \\
(n=7 \text { pairs })\end{array}$ & $\begin{array}{c}7.6 \pm 5.7 \\
(n=7 \text { pairs })\end{array}$ \\
\hline Spike recovery (\%) & & & & $\begin{array}{c}107.2 \pm 8.3 \\
(n=6)\end{array}$ & \\
\hline $\begin{array}{l}\text { Ongoing procedural } \\
\text { recovery (\%) }\end{array}$ & & & & $\begin{array}{l}96.5 \pm 7.5 \\
(n=15)\end{array}$ & \\
\hline Detection limit & $0.049 \mathrm{ng} \mathrm{g}^{-1}$ & $0.009 \mathrm{ng} \mathrm{g}^{-1}$ & $\begin{array}{l}0.01-0.45 \\
\mathrm{ng} \mathrm{g}^{-1}\end{array}$ & $0.04 \mathrm{ng} \mathrm{g}^{-1}$ & $0.01 \mathrm{ng} \mathrm{g}^{-1}$ \\
\hline
\end{tabular}




\subsubsection{Porewater Laboratory Analyses}

Porewater was assessed for $\mathrm{pH}$, concentrations of major anions (sulfate, nitrate and chloride), and dissolved organic carbon (DOC) quantity and quality. Porewater $\mathrm{pH}$ was measured on the same day as porewater collection. Major anions (sulfate, nitrate and chloride) were assessed on a Perkin Elmer ion chromatograph with autosupressor (Alltech ERIS 1000HP) at the ANALEST facility of the University of Toronto. Dissolved organic carbon in porewaters was measured with a TOC/TN analyser (Shimadzu TOC-VCSH with autosampler). Aliquots of samples collected for DOC analysis were transferred to a clear $1 \mathrm{~cm}$ diameter quartz cell, and the specific UV absorbance (in inverse meters, $\mathrm{m}^{-1}$ ) collected at $254 \mathrm{~nm}$ on an Agilent $8453 \mathrm{UV}-\mathrm{Vis}$ spectrophotometer at the University of Toronto TRACES facility. To obtain the SUVA 254 value for each sample, which conveys an estimate of aromaticity and recalcitrance of dissolved organic carbon (Weishaar et al., 2003), this absorbance was corrected for the DOC content of the porewaters and reported in $1 \mathrm{mg}^{-1} \mathrm{~m}^{-1}$ (EPA Method 415.3).

\subsubsection{Plant Laboratory Analyses}

Following mercury incubations, plants were carefully removed from the cores and washed copiously with tap water to remove sediment. In order to estimate the release of organic carbon into the rhizosphere, roots were submerged in 100-1000 $\mathrm{ml}$ of DI water, and the plant maintained under fluorescent growlights for 19 hours. This water was filtered through a $0.2 \mu \mathrm{m}$ syringe filter and stored in the dark at $4^{\circ} \mathrm{C}$ until analysis for DOC concentrations and $\mathrm{SUVA}_{254}$ using the same methods applied to porewaters (Miya and Firestone, 2001). After these incubations, the plant was separated into above and belowground biomass and oven-dried at $104^{\circ} \mathrm{C}$ for 24 hours to collect dry biomass weights. Using the concentration of DOC in the incubation water, the total mass of carbon exuded by each plant was calculated and normalized to the plant size.

\subsubsection{Statistical Analysis}

Variables were assessed for normality using q-q plots and frequency distribution histograms, and transformed to approximate a normal distribution as necessary. Relationships between ancillary biogeochemical variables and $\mathrm{Hg}$ variables were assessed using a Pearson correlation matrix at $\alpha$ $\leq 0.05$. Homogeneity of variance was tested using Levene's test. Differences among seasons and 
wetlands were assessed using a two-way ANOVA with White's adjustment for heterogeneity of variance as necessary (MacKinnon and White, 1985). Statistical analysis was conducted with $R$ version 3.3.1 (R Core Team, 2016).

\subsection{Results and Discussion}

\subsubsection{Mercury in Stormwater Wetlands}

Inorganic $\mathrm{Hg}$ levels in these stormwater wetlands ranged from 2-45.8 $\mathrm{ng} \mathrm{g}^{-1}$, and were approximately one third to one half of the concentrations found in other stormwater wetlands in southern Ontario (Chapter 2). The watersheds surrounding these wetlands were small and did not contain high-traffic roadways, suggesting that low inputs of IHg explain this pattern (Eckley and Branfireun, 2008). Overall, IHg concentrations were highest in the mature, undredged wetland (26.86 $\left.\pm 12.36 \mathrm{ng} \mathrm{g}^{-1}\right)$, probably reflecting the accumulation of ongoing inputs (Liebens, 2001) and sorption to organic matter, which comprised 5.7\% of the sediment mass (Table 3.2). In the new wetland, extremely low organic matter content (mean of $1.1 \%$ ) and the short depositional history of the site likely explain the very low IHg levels $\left(6.37 \pm 2.49 \mathrm{ng} \mathrm{g}^{-1}\right.$, Figure 1). In the dredged wetland, the concentration of IHg in individual subsites was overall similar to levels in the newly created wetland (Table 3.3). However, marked spatiotemporal variability in IHg concentrations between sampling subsites and across seasons (Figure 3.2, Table 3.3) in the dredged wetland resulted in a mean IHg burden intermediate between the new and the mature wetland $\left(16.35 \pm 13.28 \mathrm{ng} \mathrm{g}^{-1}\right)$. Although IHg in the mature and dredged wetlands appeared to vary across seasons (Figure 2$)$, these differences were not significant $\left(F_{2}=2.05, p=0.065\right)$, and probably represent fine-scale spatial variability in IHg between sampling subsites rather than a meaningful change in $\mathrm{IHg}$ deposition between seasons. Inorganic mercury and $\mathrm{MeHg}$ correlated significantly ( $\mathrm{p}<0.02, \mathrm{r}=0.674$ ), which concurs with results from Chapter 2 and is likely the result of an unusually low variability in the proportion of $\mathrm{IHg}$ which is bioavailable for methylation. Supporting this interpretation, $\mathrm{IHg}$ displayed a marginally significant correlation with $\mathrm{K}_{\text {meth }}(\mathrm{p}=0.06, \mathrm{r}=0.465)$ suggesting the availability of IHg substrate helped regulate the production of MeHg in these systems. 
(a) Inorganic Mercury

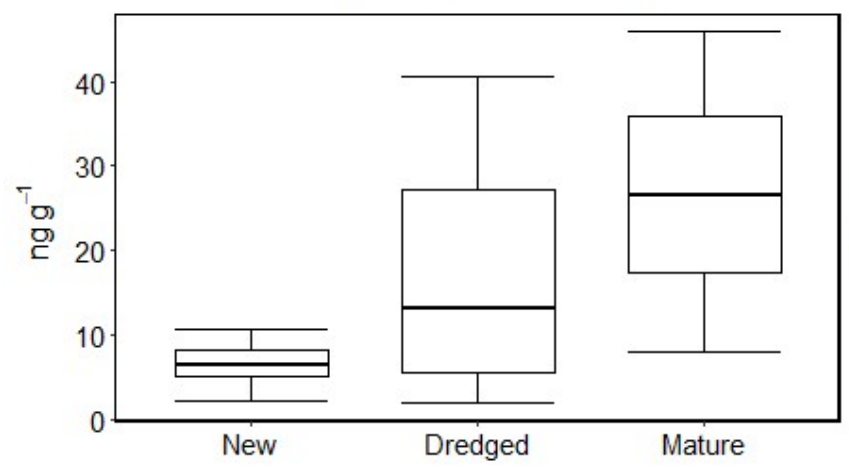

(b) Methylmercury

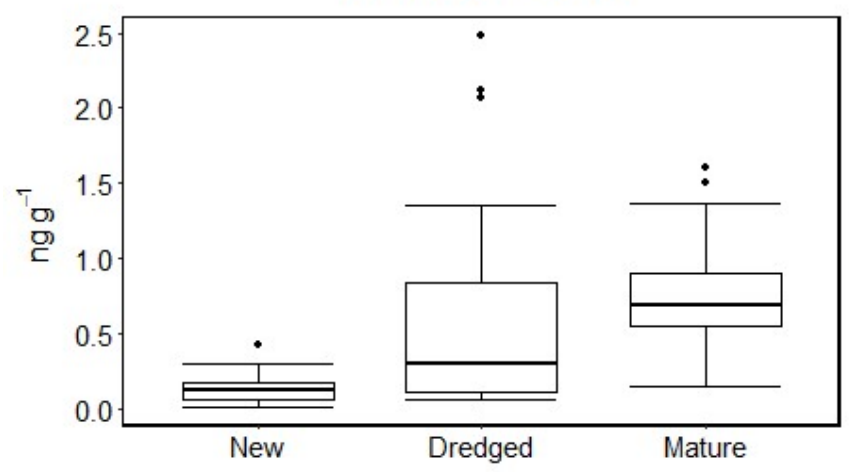

(c) Percent Methylmercury

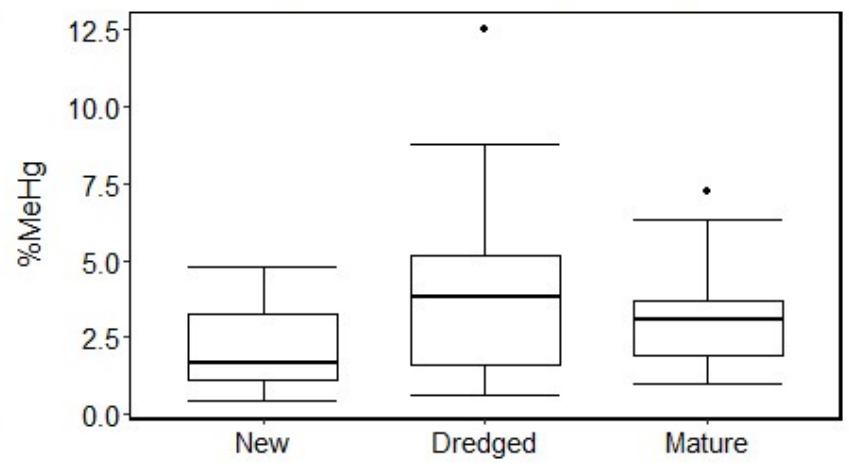

(d) $\mathrm{K}_{\text {meth }}$

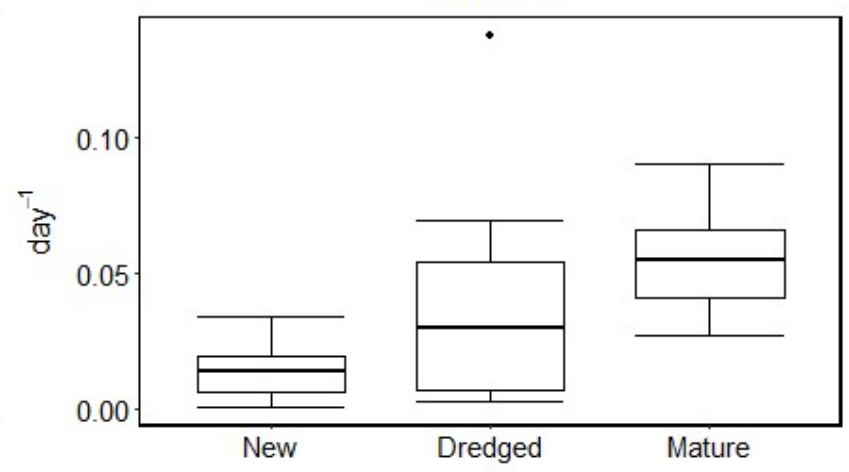

Figure 3.1: Tukey's box plot distribution of $\mathrm{Hg}$ variables in a new, a dredged, and a mature stormwater wetland. Figure displays a) inorganic mercury, b) methylmercury, c) percent of mercury present as methylmercury (Percent $\mathrm{MeHg}, \% \mathrm{MeHg})$ and d) potential methylation rate constants $\left(\mathrm{K}_{\text {meth }}\right)$.

Methylmercury levels were similar to those found in stormwater ponds investigated in Chapter 2, and ranged from $0.02-2.48 \mathrm{ng} \mathrm{g}^{-1}$, with an overall mean of $0.55 \mathrm{ng} \mathrm{g}^{-1}$ (Figure 3.1). Also in concurrence with the work presented in Chapter 2, MeHg concentrations followed a notably different age-related pattern than that observed in other types of wetlands. While there were no significant differences in $\mathrm{MeHg}$ concentrations in any wetland over the growing season $\left(\mathrm{F}_{2}=\right.$ $1.758, \mathrm{p}=0.184$ ), sediment $\mathrm{MeHg}$ concentrations in individual wetlands differed significantly $\left(F_{2}=19.59, p<0.001\right.$, Figure 3.1). The newly constructed wetland had the lowest levels of $\mathrm{MeHg}\left(0.015 \pm 0.11 \mathrm{ng} \mathrm{g}^{-1}\right)$, while the mature wetland had the highest $\left(0.79 \pm 0.41 \mathrm{ng} \mathrm{g}^{-1}\right.$; Figure $3.1 \mathrm{~b})$ and values in the dredged wetland were intermediate $\left(0.68 \pm 0.83 \mathrm{ng} \mathrm{g}^{-1}\right)$. This pattern contrasts with previous work that compared $\mathrm{MeHg}$ dynamics across wetlands of different ages. These reports, which derive from environments as diverse as beaver ponds (Roy et al., 2009), 
constructed habitat wetlands (Sinclair et al., 2012), and created reservoirs (St. Louis et al., 2004) consistently found that $\mathrm{MeHg}$ accumulation was enhanced in younger wetlands and subsequently declined.

This disparity between previous work and our findings in stormwater wetlands likely results from differences in the biogeochemistry and microbiology of the wetland sediment. Methylmercury production, as assessed through isotope incubations, was the most important determinant of $\mathrm{MeHg}$ concentrations and $\% \mathrm{MeHg}$ in sediment, suggesting that the development and activity of the $\mathrm{Hg}$ methylating microflora helps to modulate $\mathrm{MeHg}$ levels in stormwater wetlands at different stages in the management cycle. Methylation rate constants correlated significantly with both absolute $\mathrm{MeHg}$ concentrations $(\mathrm{p}<0.01, \mathrm{r}=0.80)$ and $\% \mathrm{MeHg}(\mathrm{p}<0.01$, $\mathrm{r}=0.76$ ), indicating that $\mathrm{MeHg}$ dynamics in these wetlands were controlled by net methylation rather than net demethylation. Mercury methylation rate constants measure the ability of the microbial community to methylate a standardized amount of newly added $\mathrm{Hg}$, rather than their ability to methylate $\mathrm{Hg}$ that is already present. Low $\mathrm{K}_{\text {meth }}$ values in the new wetland $(0.001-$ 0.034 day $^{-1}$ ) therefore suggest that the Hg methylating microflora was less active or less abundant than that in the mature wetland, which methylated $\mathrm{Hg}$ at higher rates $\left(0.027-0.090\right.$ day $^{-}$ 1; Figure 3.1). Newly created wetlands have been previously observed to be less active in terms of other microbially mediated biogeochemical processes, such as nitrogen cycling (Wolf et al., 2011) suggesting that the sediments had not yet been abundantly populated by typical wetland $\mathrm{Hg}$ methylators or that their activity was depressed by suboptimal conditions. The mature wetland had likely developed a microbial community relatively similar to a natural wetland (Duncan and Groffman, 1994), including the evident presence and greater activity of $\mathrm{Hg}$ methylators. In the dredged wetland, $\mathrm{K}_{\text {meth }}$ values were very low during the early summer, but subsequently rebounded over the growing season to levels more similar to those found in the mature wetland, explaining the concurrent increases in $\mathrm{MeHg}$ concentrations (Figure 3.2). Over the same time period, $\mathrm{MeHg}$ production in the new wetland remained low, suggesting that the rebound in $\mathrm{MeHg}$ production in the dredged wetland was the result of more rapid recolonization of the sediments by $\mathrm{Hg}$ methylating microbiota from pockets of undredged sediment, rather than a response to broader seasonal changes in temperature or precipitation. Previous work has found 
that wetland microfloras, including the mercury methylating subset, are resilient to other types of disturbance (Allison and Martiny, 2008; Strickman et al., 2016), supporting this interpretation.

(a) Inorganic Mercury

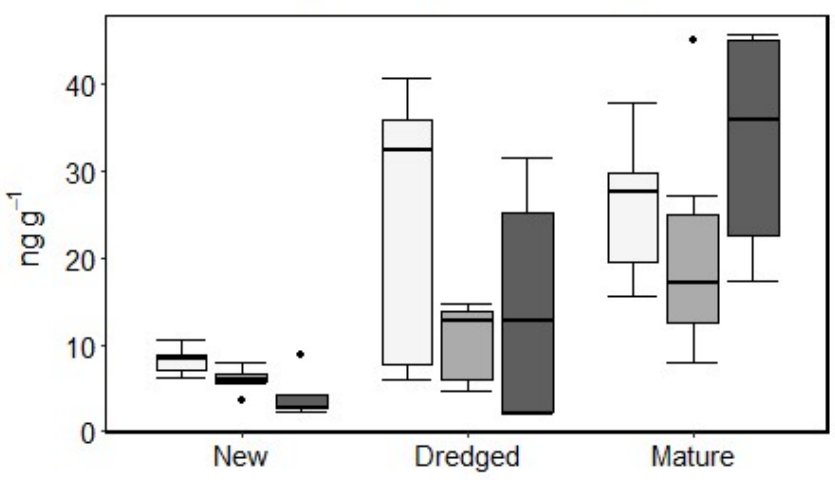

(b) Methylmercury

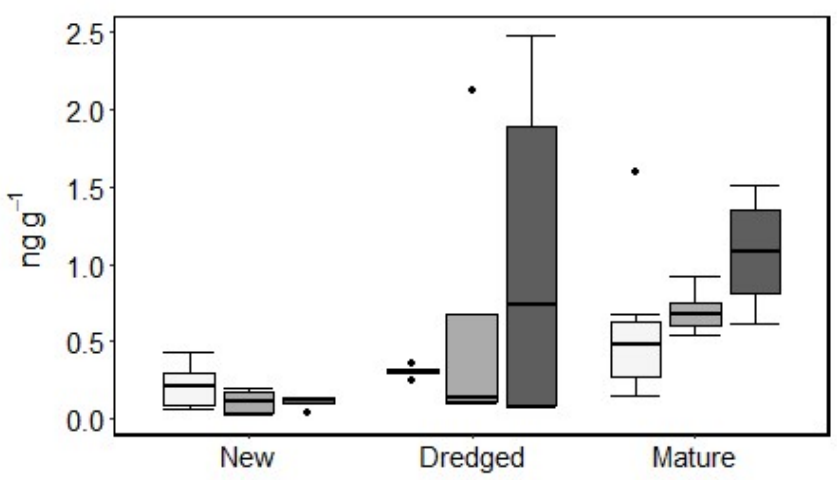

(c) Percent MeHg

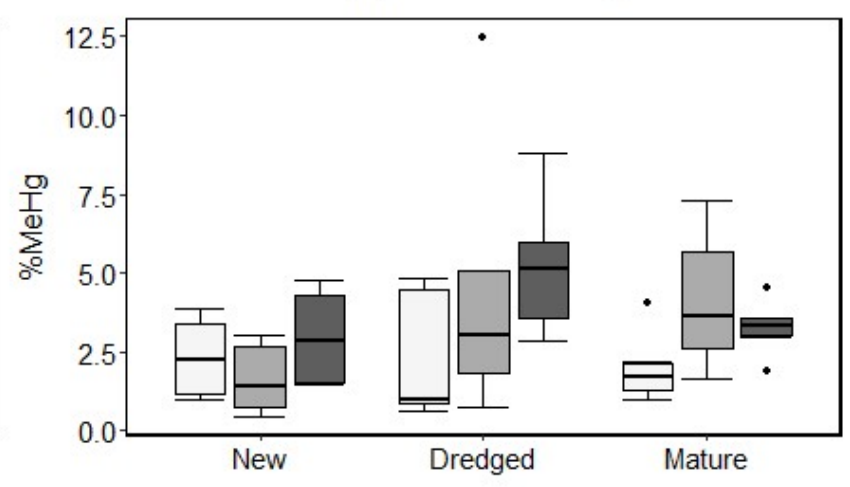

(d) $\mathrm{K}_{\text {meth }}$

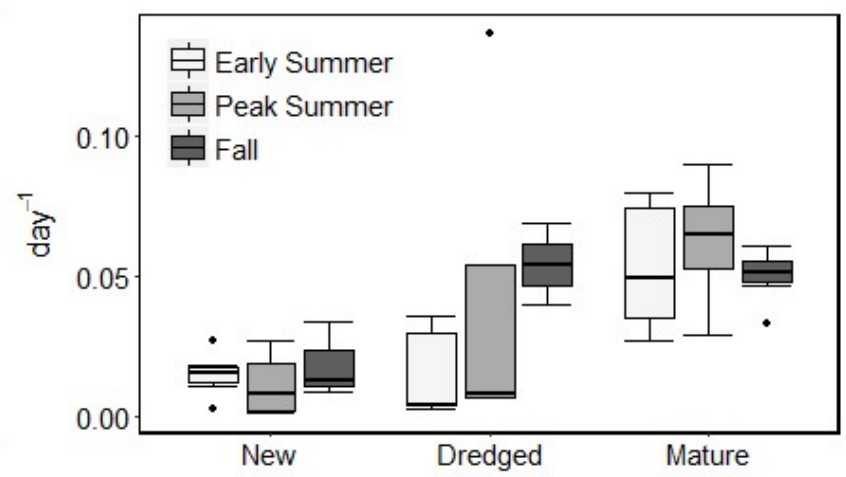

Figure 3.2: Distribution of mercury variables over early summer, peak summer, and fall in a new, a dredged, and a mature wetland. Figure displays a) inorganic mercury, b) methylmercury, c) percent of mercury present as methylmercury (Percent $\mathrm{MeHg}, \% \mathrm{MeHg}$ ) and d) potential methylation rate constants $\left(\mathrm{K}_{\text {meth }}\right)$. 
Table 3.2: Summary of porewater chemistry and sediment physical parameters from the new, dredged, and mature stormwater pond. Data are presented separately for seasons (Early Summer, Peak Summer, and Fall) and zones within the wetland (L: littoral, P: pelagic). Where applicable, data is summarized as mean \pm standard deviation.

\begin{tabular}{|c|c|c|c|c|c|c|c|c|c|c|c|}
\hline & & \multicolumn{7}{|c|}{ Porewater Chemistry } & \multicolumn{3}{|c|}{ Sediment Physical Parameters } \\
\hline & & & $\begin{array}{c}\text { Chloride } \\
\left(\mathrm{mg} \mathrm{l}^{-1}\right)\end{array}$ & $\begin{array}{l}\text { Nitrate } \\
\left(\mathrm{mg} \mathrm{l}^{-1}\right)\end{array}$ & $\begin{array}{l}\text { Sulfate } \\
\left(\mathrm{mg} \mathrm{l}^{-1}\right)\end{array}$ & $\begin{array}{c}\mathrm{DOC} \\
\left(\mathrm{mg} \mathrm{l}^{-1}\right)\end{array}$ & $\begin{array}{c}\text { SUVA } \\
254\end{array}$ & $\mathrm{pH}$ & $\begin{array}{c}\text { Organic Matter } \\
(\%)\end{array}$ & $\begin{array}{c}\text { Volumetric } \\
\text { moisture } \\
\text { content }(\%)\end{array}$ & $\begin{array}{c}\text { Bulk } \\
\text { Density } \\
\left(\mathrm{g} \mathrm{cm}^{-3}\right)\end{array}$ \\
\hline \multirow{6}{*}{$\frac{3}{2}$} & \multirow{2}{*}{$\begin{array}{c}\text { Early } \\
\text { Summer }\end{array}$} & L & 74.96 & 1.23 & 39.89 & 109.17 & 0.22 & 8.09 & $0.6 \pm 0.1$ & $0.29 \pm 0.03$ & $1.4 \pm 0.2$ \\
\hline & & $\mathrm{P}$ & 76.10 & 1.40 & 62.78 & 94.75 & 0.2 & 8.38 & $0.9 \pm 0.6$ & $0.38 \pm 0.07$ & $1.1 \pm 0.3$ \\
\hline & \multirow{2}{*}{$\begin{array}{l}\text { Peak } \\
\text { Summer }\end{array}$} & L & 122.21 & 8.39 & - & 13.97 & 0.92 & - & 1.1 & 0.4 & 2.44 \\
\hline & & $\mathrm{P}$ & 83.39 & 1.06 & 52.28 & 5.86 & 1.62 & 7.82 & 2.8 & 0.37 & 2.26 \\
\hline & \multirow{2}{*}{ Fall } & $\mathrm{L}$ & 96.54 & 2.52 & 80.17 & 164.67 & 0.18 & 8.52 & 0.8 & 0.14 & 0.72 \\
\hline & & $P$ & 101.34 & 3.22 & 111.55 & 203.87 & 0.12 & 8.34 & 1.3 & 0.18 & 1.02 \\
\hline \multirow{6}{*}{ 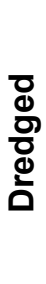 } & \multirow{2}{*}{$\begin{array}{c}\text { Early } \\
\text { Summer }\end{array}$} & $\mathrm{L}$ & 340.64 & 9.56 & 33.51 & 49.45 & 5.07 & 8.26 & $14.9 \pm 6.6$ & $<0.01$ & $0.7 \pm 0.1$ \\
\hline & & $\mathrm{P}$ & 36.19 & 0.95 & 2.52 & 61.11 & 1.14 & 8.81 & 3.5 & $0.04 \pm 0.01$ & 1.43 \\
\hline & \multirow{2}{*}{$\begin{array}{l}\text { Peak } \\
\text { Summer }\end{array}$} & $\mathrm{L}$ & 214.91 & 1.26 & 56.82 & - & - & 7.38 & $2.3 \pm 0.8$ & $0.01 \pm 0$ & $2.1 \pm 0.5$ \\
\hline & & $P$ & 269.80 & 0.96 & 162.47 & - & - & 8.20 & 11.9 & $0.1 \pm 0.06$ & 0.65 \\
\hline & \multirow{2}{*}{ Fall } & L & 299.92 & 11.10 & 139.23 & - & - & - & 2.4 & 0.18 & 1.01 \\
\hline & & $P$ & 194.94 & 0.96 & 21.18 & 52.72 & 0.58 & 8.60 & - & - & - \\
\hline \multirow{6}{*}{$\frac{0}{\substack{\frac{1}{2} \\
\frac{\pi}{2}}}$} & \multirow{2}{*}{$\begin{array}{c}\text { Early } \\
\text { Summer }\end{array}$} & $\mathrm{L}$ & 67.68 & 1.08 & 4.23 & 180.5 & 0.15 & 8.75 & $6.1 \pm 1.8$ & $0.72 \pm 0.1$ & $0.6 \pm 0.2$ \\
\hline & & $\mathrm{P}$ & 85.85 & 1.13 & 3.17 & 224 & 0.36 & 8.33 & $2.2 \pm 0.5$ & $0.52 \pm 0.09$ & $1.2 \pm 0.1$ \\
\hline & \multirow{2}{*}{$\begin{array}{c}\text { Peak } \\
\text { Summer }\end{array}$} & L & 63.14 & 0.99 & 45.94 & 168.77 & 0.31 & 8.31 & $7.3 \pm 1.8$ & $0.82 \pm 0.03$ & $0.5 \pm 0.2$ \\
\hline & & $\mathrm{P}$ & 31.45 & 0.97 & 34.38 & 23.66 & 0.71 & 8.47 & $5.3 \pm 1.3$ & $0.75 \pm 0.09$ & $0.6 \pm 0.2$ \\
\hline & \multirow{2}{*}{ Fall } & $\mathrm{L}$ & 59.14 & 1.10 & 9.74 & 132.47 & 0.26 & 8.09 & $10.4 \pm 4.5$ & $0.83 \pm 0.07$ & $0.3 \pm 0.3$ \\
\hline & & $\mathrm{P}$ & 31.20 & 1.15 & 1.78 & 188.27 & 0.24 & 8.34 & $5.1 \pm 0.6$ & $0.74 \pm 0.03$ & $0.5 \pm 0.01$ \\
\hline
\end{tabular}


Table 3.3: Summary of sediment chemistry and mercury variables from the new, dredged, and mature stormwater pond. Data are presented separately for seasons (Early Summer, Peak Summer, and Fall) and zones within the wetland ( $\mathrm{L}$ : littoral, $\mathrm{P}$ : pelagic). Where applicable, data is summarized as mean \pm standard deviation.

\begin{tabular}{|c|c|c|c|c|c|c|c|c|c|c|}
\hline & & & & Sediment & Chemistr & & & jediment $\mathbf{N}$ & Eury Varic & \\
\hline & & & $\begin{array}{l}\text { Ferrous iron } \\
\quad\left(\mu \mathrm{g} \mathrm{g}^{-1}\right)\end{array}$ & $\begin{array}{l}\text { Ferric iron } \\
\left(\mu \mathrm{g} \mathrm{g}^{-1}\right)\end{array}$ & $\begin{array}{l}\text { Nitrate-N } \\
\left(\mu \mathrm{g} \mathrm{g}^{-1}\right)\end{array}$ & $\begin{array}{c}\text { Ammonia-N } \\
\left(\mu \mathrm{g} \mathrm{g}^{-1}\right)\end{array}$ & $\begin{array}{l}\mathrm{MeHg} \\
\left(\mathrm{ng} \mathrm{g}^{-1}\right)\end{array}$ & $\begin{array}{c}\mathrm{IHg} \\
\left(\mathrm{ng} \mathrm{g}^{-1}\right)\end{array}$ & $\% \mathrm{MeHg}$ & $\mathrm{K}_{\text {meth }}$ \\
\hline & Early & L & $1929 \pm 686$ & $389 \pm 102$ & $0.05 \pm 0.06$ & $0.72 \pm 0.001$ & $0.08 \pm 0.03$ & $7.04 \pm 1.17$ & $1.12 \pm 0.14$ & $0.011 \pm 0.008$ \\
\hline & Summer & $P$ & $2390 \pm 659$ & $395 \pm 94$ & $16.25 \pm 15.45$ & $3.31 \pm 0.74$ & $0.34 \pm 0.08$ & $9.31 \pm 1.18$ & $3.51 \pm 0.32$ & $0.019 \pm 0.007$ \\
\hline 3 & Peak & L & $2881 \pm 155$ & $508 \pm 341$ & $0.51 \pm 0.4$ & $0.93 \pm 0.44$ & $0.04 \pm 0.03$ & $5.34 \pm 1.59$ & $0.73 \pm 0.33$ & $0.002 \pm 0.001$ \\
\hline $\mathbf{z}$ & Summer & $P$ & $2101 \pm 86$ & $544 \pm 384$ & 0.31 & 2.13 & $0.18 \pm 0.03$ & $6.73 \pm 1.11$ & $2.61 \pm 0.71$ & $0.021 \pm 0.007$ \\
\hline & & L & $2583 \pm 278$ & $35 \pm 60$ & $4.91 \pm 4.24$ & $1.34 \pm 0.03$ & $0.1 \pm 0.05$ & $2.58 \pm 0.27$ & $3.5 \pm 1.7$ & $0.022 \pm 0.018$ \\
\hline & . & $P$ & 2444 & 271 & $<\mathrm{DL}$ & 0.69 & 0.13 & 8.84 & 1.45 & 0.013 \\
\hline & Early & L & $3226 \pm 977$ & $784 \pm 232$ & $13.5 \pm 15.26$ & $23.27 \pm 3.57$ & $0.29 \pm 0.04$ & $36.32 \pm 4.12$ & $0.82 \pm 0.18$ & $0.004 \pm 0.001$ \\
\hline & Summer & $\mathrm{P}$ & - & - & $<\mathrm{DL}$ & $8.06 \pm 1.75$ & $0.33 \pm 0.04$ & $6.8 \pm 1.25$ & $4.67 \pm 0.26$ & $0.033 \pm 0.004$ \\
\hline 용 & Peak & $\mathrm{L}$ & $1596 \pm 481$ & $311 \pm 83$ & $1.94 \pm 0.67$ & $2.03 \pm 0.27$ & $0.12 \pm 0.02$ & $8.15 \pm 4.92$ & $1.85 \pm 1.14$ & $0.007 \pm 0.001$ \\
\hline ฮ & Summer & $\mathrm{P}$ & $1893 \pm 128$ & $316 \pm 14$ & 1. $09 \pm 0.63$ & $19.75 \pm 5.59$ & $1.4 \pm 1.02$ & $13.78 \pm 1.48$ & $8.78 \pm 5.25$ & $0.096 \pm 0.059$ \\
\hline & & L & $2552 \pm 1318$ & $16 \pm 28$ & - & - & $1.97 \pm 0.57$ & $26.81 \pm 4.37$ & $6.83 \pm 1.73$ & $0.054 \pm 0.015$ \\
\hline & & $P$ & $1980 \pm 245$ & $154 \pm 80$ & $<\mathrm{DL}$ & $2.04 \pm 0.89$ & $0.09 \pm 0.03$ & $2.22 \pm 0.2$ & $3.57 \pm 1$ & - \\
\hline & Early & L & $8333 \pm 695$ & $855 \pm 194$ & $<\mathrm{DL}$ & $9.53 \pm 6.17$ & $0.86 \pm 0.64$ & $31.05 \pm 6.13$ & $2.5 \pm 1.35$ & $0.073 \pm 0.011$ \\
\hline & Summer & $\mathrm{P}$ & $4283 \pm 453$ & $314 \pm 195$ & $0.1 \pm 0.12$ & $17.69 \pm 19.48$ & $0.34 \pm 0.28$ & $20.91 \pm 7.8$ & $1.46 \pm 0.64$ & $0.033 \pm 0.006$ \\
\hline$\frac{\emptyset}{2}$ & Peak & L & $2003 \pm 893$ & $781 \pm 402$ & - & - & $0.66 \pm 0.09$ & $29.25 \pm 14.92$ & $2.54 \pm 1.04$ & $0.057 \pm 0.025$ \\
\hline$\sum^{\pi}$ & Summer & $P$ & $4189.5 \pm 3113.9$ & $532.1 \pm 175.9$ & - & - & $0.72 \pm 0.19$ & $12.89 \pm 5.54$ & $5.73 \pm 1.9$ & $0.069 \pm 0.021$ \\
\hline & & L & $3941.4 \pm 1302.7$ & $<\mathrm{DL}$ & 0.45 & 2.48 & $1.25 \pm 0.33$ & $45.23 \pm 0.49$ & $2.7 \pm 0.71$ & $0.055 \pm 0.006$ \\
\hline & rall & $\mathrm{P}$ & $6309.6 \pm 1668.1$ & $<\mathrm{DL}$ & $0.22 \pm 0.38$ & $40.75 \pm 18.03$ & $0.89 \pm 0.34$ & $21.83 \pm 4.73$ & $3.85 \pm 0.59$ & $0.069 \pm 0.021$ \\
\hline
\end{tabular}

\subsubsection{Spatial Variability in Hg Biogeochemistry within Stormwater Wetlands}

One of the aims of this project was to observe the relationship between $\mathrm{MeHg}$ biogeochemistry and the developing plant community in stormwater wetlands over the course of a growing season. Littoral zones were selected in areas that were already vegetated (in the mature wetland) or on the fringe of the wetland where vegetation was likely to develop, while the pelagic zones were selected as unvegetated within-wetland controls. However, in contrast to expectations, plant communities did not develop in the new or dredged wetlands within the first growing season. 
This lack of replication limited the investigation of Hg-plant relationships to the vegetated littoral zone of the mature wetland, which hosted abundant large plants (Table 3.4). In this wetland, no correlations were found between plant biomass or activity, and any Hg variable ( $p=0.168$ 0.991). Additionally, no difference in $\mathrm{MeHg}$ concentrations, production, or $\% \mathrm{MeHg}$ was found between the vegetated littoral and unvegetated pelagic zones of the mature wetland $\left(\mathrm{F}_{1}=1.146-\right.$ $2.051, \mathrm{p}=0.171-0.30$ ). These results are based on methylation rate assays conducted with living plants in situ, a unique approach which closely linked MeHg production with the presence of aquatic vegetation. My finding that plants do not markedly stimulate MeHg production in stormwater wetland thus extends and strongly supports the findings of Chapter 2. However, this contrasts with observations of increased $\mathrm{MeHg}$ production and accumulation in vegetated areas of rice paddies, natural California wetlands, tidal mudflats and a freshwater reservoir (Canário et al., 2007; Regier et al., 2012; Windham-Myers et al., 2009), where the presence of plants stimulated the activity of mercury methylators through the release of root exudates (Cosio et al., 2014) and concentrated MeHg in the rhizosphere as a result of transpiration-driven movement of porewater (Bachand et al., 2014). While the reasons for this disparity are not clear, the bulk of evidence indicates that plant-mediated stimulation of $\mathrm{Hg}$ methylation does not occur in stormwater wetlands to the same degree as in other systems.

Table 3.4: Summary of plant biomass and carbon exudate from the littoral zone of the mature wetland for Early Summer, Peak Summer, and Fall. Data is summarized as mean \pm standard deviation.

\begin{tabular}{lcccc}
\hline \hline & \multicolumn{4}{c}{ Plant variables } \\
\cline { 2 - 5 } & $\begin{array}{c}\text { Aboveground } \\
\text { biomass }(\mathrm{g})\end{array}$ & $\begin{array}{c}\text { Belowground } \\
\text { biomass }(\mathrm{g})\end{array}$ & $\begin{array}{c}\text { Plant exudate } \\
\left(\mathrm{mg} \mathrm{l}^{-1}\right. \\
\left.\text { giomass }^{-1}\right)\end{array}$ & SUVA $_{254}$ \\
Early Summer & $7.77 \pm 4.02$ & $1.28 \pm 0.77$ & $1.94 \pm 0.69$ & $0.18 \pm 0.08$ \\
Peak Summer & $22.8 \pm 6.51$ & $10.8 \pm 3.96$ & $0.13 \pm 0.09$ & $0.71 \pm 0.03$ \\
Fall & $18.03 \pm 4.87$ & $4.37 \pm 1.19$ & $0.1 \pm 0.03$ & $0.46 \pm 0.12$ \\
\hline \hline
\end{tabular}

Spatial variability in $\mathrm{MeHg}$ production and concentrations, unrelated to the presence of vegetation, was observed in the dredged wetland. While mean $\mathrm{MeHg}$ concentrations in the dredged wetland were similar to those in the mature wetland (Table 3.3), a detailed examination of data from individual sampling subsites reveals that $\mathrm{MeHg}$ concentrations were overall very 
low and similar to those found in the new wetland. Superimposed on this pattern, were two "hot spots" of ten- to twenty-fold greater MeHg production, leading to similarly, disproportionately high $\mathrm{MeHg}$ concentrations and \% MeHg values (Figure 3.3). While the reasons for the increased MeHg production at these two subsites cannot be conclusively determined, it is notable that these two sampling subsites had significantly elevated porewater sulfate concentrations relative to the other samples from the same wetland (Figure 3.3). As observed in other systems, increased concentrations of porewater sulfate may have stimulated the activity of sulfate reducing mercury methylators, resulting in higher rates of mercury methylation and greater net $\mathrm{MeHg}$ accumulation (Åkerblom et al., 2013; Gilmour et al., 1992; Jeremiason et al., 2006). The source of this high porewater sulfate may be related to the dredging process, which exposed sediments to oxygen and likely regenerated sulfate from reduced sulfur species (Feng et al., 2014; Oswald and Carey, 2016), with this supply distributed heterogeneously over the wetland's basin.

\subsubsection{Biogeochemical Controls on Hg in Stormwater Ponds}

Mercury methylation in stormwater wetlands appears to be carried out by sulfate reducing $\mathrm{Hg}$ methylators, a group which also dominates $\mathrm{Hg}$ methylation in a wide range of other freshwater environments (Gilmour et al., 1992; Podar et al., 2015). Although no overall correlation was identified between porewater sulfate and any Hg variable $(p=0.325-0.910)$, two other lines of evidence suggest that these bacteria were involved in $\mathrm{Hg}$ methylation in our study sites. Firstly, the concurrence of elevated $\mathrm{MeHg}$ concentrations, $\mathrm{K}_{\text {meth }} \% \mathrm{MeHg}$ and porewater sulfate in the dredged wetland strongly suggests the involvement sulfate reducers in the production of MeHg. Secondly, a negative relationship was identified between porewater nitrate and $\mathrm{K}_{\text {meth }}(\mathrm{p}=0.011$, $\mathrm{r}=-0.60$ ). Nitrate has been previously linked with reduced MeHg production in a lake hypolimnion (Todorova et al. 2009) and a subsurface streambed bioreactor, where it created this effect by allowing nitrate reducers to divert carbon and energy flows from sulfate reducers (Shih et al., 2011). Supporting this interpretation, nitrate porewater concentrations in the stormwater wetlands were very high $\left(2.7 \pm 3.2 \mathrm{mg} \mathrm{l}^{-1}\right)$ compared to similar natural wetlands in Southern Ontario (0.0081 mg ${ }^{-1}$; Chiandet and Xenopoulos, 2016). From the available evidence, I infer that $\mathrm{Hg}$ methylation in our study sites was carried out by SRB that were limited by competition with nitrate reducers, rather than the availability of sulfate, which was in great enough abundance to stimulate methylating microbes. The sulfate concentrations found at the two "hot spots" in the 
dredged wetland were high in relation to the background sulfate usually found in Ontario created wetlands (150 $\mathrm{mg}^{1^{-1}}$ versus $1-10 \mathrm{mg} \mathrm{l}^{-1}$; Fortin et al., 2000), which may have allowed the sulfate reducing bacteria to overcome this competitive inhibition (Lovley and Klug, 1983). Elevated nitrate in stormwater wetlands (Galloway et al., 2003; Taylor et al., 2005), and its concurrent competitive depression of sulfate reducers, may thus help explain the relatively low $\mathrm{MeHg}$ concentrations in stormwater wetlands in comparison to other constructed wetlands (Chapter 2).

(b) Methylmercury

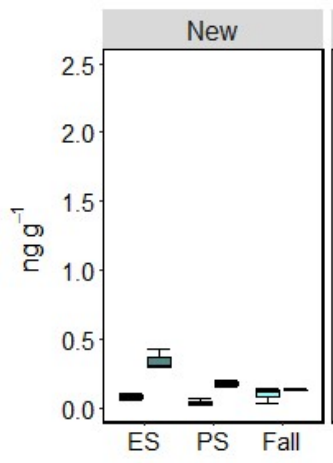

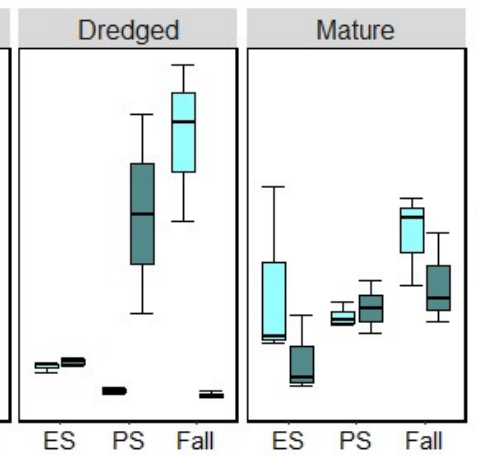

(b) Percent MeHg (c) $\mathrm{K}_{\text {meth }}$

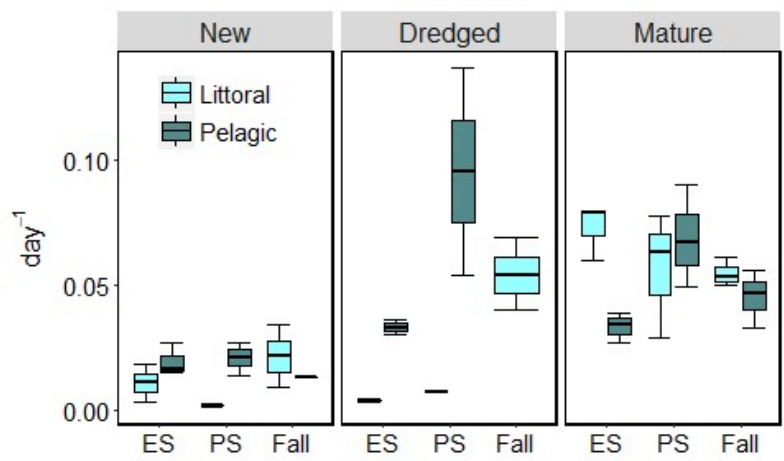

(d) Porewater Sulfate

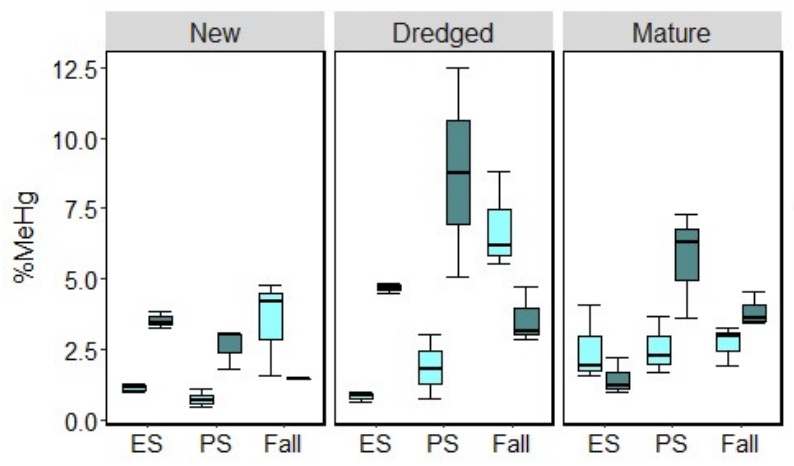

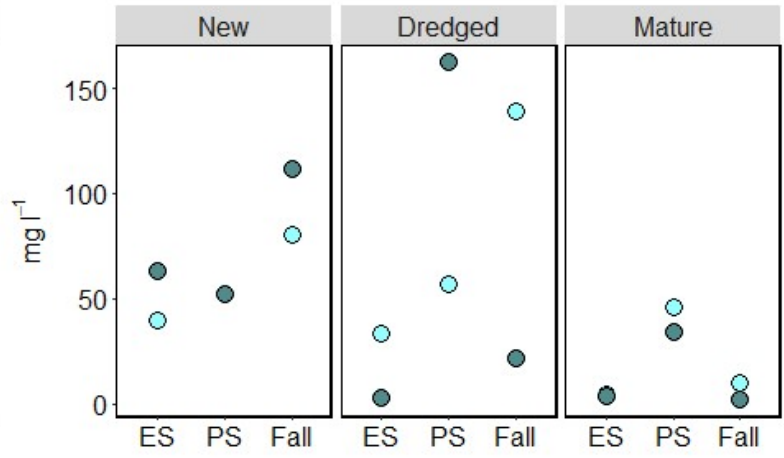

Figure 3.3: Spatial distribution of a) methylmercury, b) percent of mercury present as methylmercury $(\% \mathrm{MeHg}), \mathrm{c})$ potential methylation rate constants $\left(\mathrm{K}_{\mathrm{meth}}\right)$ and $\left.\mathrm{d}\right)$ porewater sulfate concentrations between the littoral and pelagic zones over the early summer (ES), peak summer (PS), and fall (Fall) of a new, a dredged, and a mature wetland. Methylmercury, $\% \mathrm{MeHg}$, and $\mathrm{K}_{\text {meth }}$ values are summarized with Tukey's boxplots; porewater sulfate measurements were measured only once per zone at each season, and are indicated with dots. 
In concurrence with the results obtained in Chapter 2, I found evidence that the organic matter dynamics of stormwater ponds helped modulate $\mathrm{MeHg}$ biogeochemistry in two ways. Firstly, sediment organic matter likely scavenged IHg and held it sorbed to cation exchange sites (He et al., 2007; Ullrich et al., 2001), as revealed by the significant, positive relationship between organic matter and $\mathrm{IHg}(\mathrm{p}<0.01, \mathrm{r}=0.74)$. Given the importance of $\mathrm{IHg}$ substrate in governing $\mathrm{MeHg}$ production in these wetlands (Section 4.4.1), the low capacity of the new stormwater wetland to trap incoming $\mathrm{IHg}$ would thus limit $\mathrm{MeHg}$ production. Secondly, higher organic matter contents likely directly stimulated $\mathrm{MeHg}$ production (Meng et al., 2016) by supporting a more abundant and more active microbial community (Schallenberg and Kalff, 1993). Supporting this interpretation, I identified a significant, positive relationship between sediment organic matter and $\mathrm{MeHg}(\mathrm{p}=0.031, \mathrm{r}=0.38)$ and a marginally significant, positive relationship between organic matter content and $\mathrm{K}_{\text {meth }}(\mathrm{p}=0.083, \mathrm{r}=0.31)$.

Patterns of organic matter content may also help explain the unusually low MeHg production and accumulation in young stormwater wetlands in comparison to other types of new natural and created wetlands. These wetlands are most frequently created by flooding upland soils, resulting in a pulsed availability of organic carbon as submerged terrestrial vegetation and carbon stores decay (Hall et al., 2005; Mailman et al., 2006; St. Louis et al., 2004). In contrast, stormwater wetlands are usually created by excavation, and are isolated from surrounding soils with a clay liner (Kadlec and Wallace, 2009; Ontario Ministry of the Environment, 2003). Reflecting this, I observed increasing organic matter from young to old stormwater wetlands (Table 3.2, Chapter 2 ), as a result of the gradual accumulation of organic carbon. This accumulation of organic matter as created wetlands age is a strong indicator that they are simultaneously developing biogeochemical cycles more characteristic of natural wetlands (Wolf et al., 2011), including the production of $\mathrm{MeHg}$.

The quality of sediment organic carbon, estimated using sediment ammonia as a proxy measure (Liu et al. 2016), also helped to regulate $\mathrm{MeHg}$ production and accumulation. Sediment ammonia had strong, positive correlations with $\mathrm{IHg}(\mathrm{p}<0.01, \mathrm{r}=0.71), \mathrm{MeHg}(\mathrm{p}<0.01, \mathrm{r}=0.66), \mathrm{K}_{\text {meth }}$ $(\mathrm{p}=0.010, \mathrm{r}=0.44)$ and $\% \mathrm{MeHg}(\mathrm{p}=0.047, \mathrm{r}=0.33)$ (Figure 3.4). While ammonia has not been commonly identified as a potential explanatory factor for $\mathrm{MeHg}$ production and accumulation, positive relationships between ammonia and trophic accumulation of $\mathrm{Hg}$ in lake 
fish (Glover et al., 2010) and concurrent increases in sediment ammonification and $\mathrm{MeHg}$ concentrations in rice paddy soil (Liu et al., 2016) have been observed. Liu et al. (2016) ascribed the relationship between sediment ammonification and $\mathrm{MeHg}$ to stimulation of microbial metabolism as the microflora degraded newly added labile carbon, and concurrently converted the labile nitrogen to ammonia (Vymazal, 2007). I suggest that a similar process was occurring in the stormwater wetlands as high-quality organic detritus was broken down, resulting in the production of ammonia, which readily sorbs to cation exchange sites in sediment (Reddy and DeLaune 2008). Supporting this interpretation, sediment ammonia and organic matter content were strongly and positively related to one another $(\mathrm{p}<0.01, \mathrm{r}=0.71)$.

The possibility also exists that sediment ammonia may indirectly stimulate unknown freshwater mercury methylators. Recently, a novel mercury methylator has been identified from the marine nitrite oxidizing bacterial genus Nitrospinsa (Gionfriddo et al., 2016; Ngugi et al., 2016). One potential explanation for the positive relationship between ammonia and mercury methylation is thus the existence of freshwater nitrite-oxidizing bacteria, which might potentially be stimulated by the nitrite produced by ammonia oxidizing bacteria (Vymazal, 2007). Given the extensive contamination of stormwater wetlands with ammonia (Kadlec and Wallace, 2009), and their apparent dissimilarity from other wetlands in terms of MeHg biogeochemistry, the possibility that sediment ammonia may directly or indirectly stimulate $\mathrm{MeHg}$ production in these environments should be examined. 
(a) Methylmercury

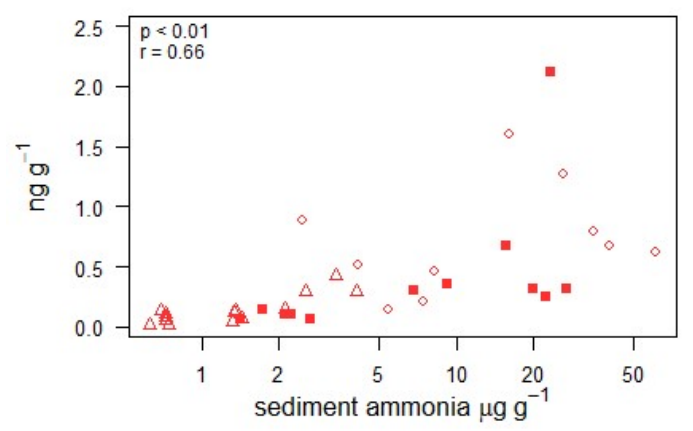

(b) Inorganic Mercury

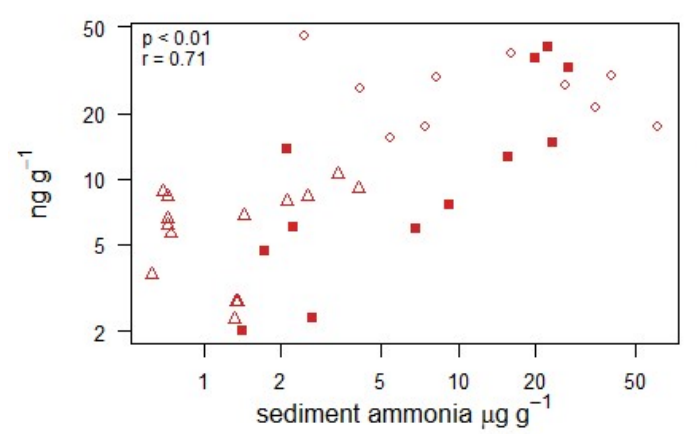

(c) Percent MeHg

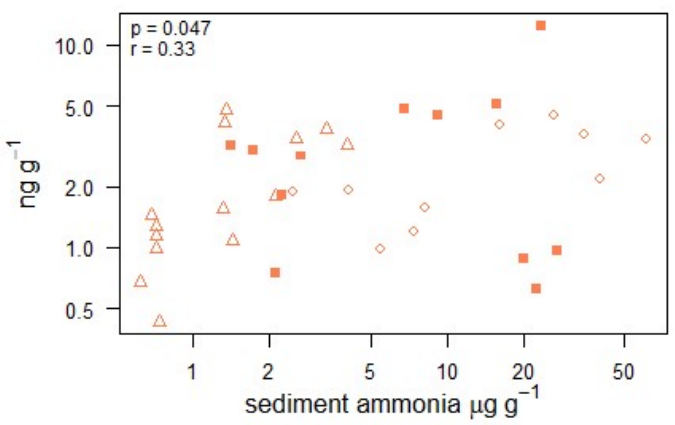

(d) $K_{\text {meth }}$

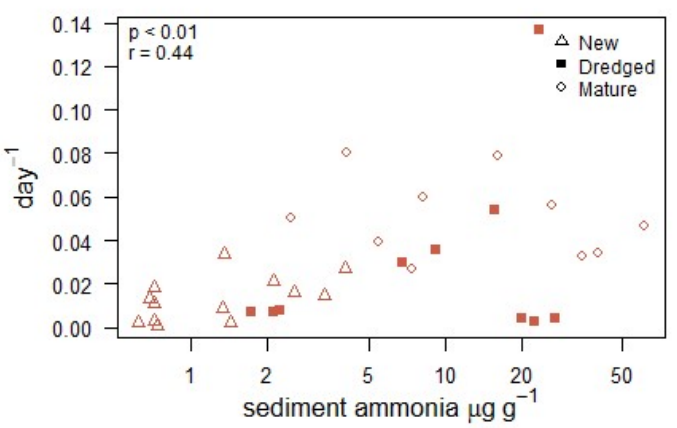

Figure 3.4: Relationships between sediment ammonia concentrations and (a) methylmercury, (b) inorganic mercury, (c) percent of mercury present as methylmercury $(\% \mathrm{MeHg})$ and (d) potential methylation rate constants $\left(\mathrm{K}_{\mathrm{meth}}\right)$. Results of Pearson correlations, obtained from transformed data, are displayed in the upper left corner. Sediment ammonia and inorganic mercury were natural log transformed; $\% \mathrm{MeHg}$ was natural $\log$ transformed, and $\mathrm{K}_{\text {meth }}$ and $\mathrm{MeHg}$ variables were square root transformed.

\subsection{Conclusions and Management Implications}

Stormwater wetlands at different stages in the management lifecycle differed in their ability to produce and accumulate $\mathrm{MeHg}$, and in the amount of $\mathrm{IHg}$ accumulated in their sediments. The newly constructed stormwater wetland, while hydrologically functional, had extremely low concentrations of IHg and produced very little $\mathrm{MeHg}$, while the mature wetland sediment had approximately five times higher $\mathrm{MeHg}$ production and concentrations. This pattern differs from previously studied natural wetlands and reservoirs, where $\mathrm{MeHg}$ production is high when the wetland is new, and subsequently declines. I believe that this inconsistency is due to both low availability of $\mathrm{IHg}$ substrate in new stormwater wetlands, and to the reduced activity of $\mathrm{Hg}$ 
methylating microbiota as a result of limitations in sediment organic matter quantity and quality. Based on these findings, I caution that the amendment of stormwater wetlands with organic matter, a management intervention which can improve several wetland functions (Ballantine et al., 2015; Bruland et al., 2009), may also inadvertently stimulate MeHg production. However, in relation to wetlands managed for habitat provision, $\mathrm{MeHg}$ production and accumulation in these stormwater wetlands was low (Chapter 2, Sinclair et al., 2012), which I speculate may be the result of competitive inhibition of sulfate-reducing $\mathrm{Hg}$ methylators by nitrate reducers. Nitrate is a common contaminant in stormwater wetlands in Ontario (Chiandet and Xenopoulos, 2016), and in other climates (Kadlec and Wallace, 2009), suggesting that this effect may be widespread and help to moderate the $\mathrm{MeHg}$ production capacity of stormwater wetlands. In concurrence with the findings of Chapter 2, I identified no relationship between plants and MeHg production and accumulation, and thus suggest that plants have little to no influence on $\mathrm{MeHg}$ production in these systems.

While dredging appeared to temporarily reduce $\mathrm{MeHg}$ production and accumulation, the effect was shortlived, and was accompanied by increased spatial variability. Methylmercury production, concentrations, and $\% \mathrm{MeHg}$ in the dredged wetland were very low immediately after the completion of the dredging process, but subsequently rebounded over the growing season to levels comparable to the mature, undredged wetland. These observations may be of concern to managers of stormwater wetlands in areas with known MeHg contamination problems (Feng et al., 2014; Rumbold and Fink, 2006). More generally, the apparent resilience of the microbial community to dredging also suggests that other, more desirable microbial functions of stormwater wetland, such as nitrate reduction or phosphorus uptake, may also be similarly resilient to wetland dredging.

\subsection{Acknowledgements}

The authors would like to thank Scott Patrick and Haiyong (Planck) Huang for invaluable support in the field and laboratory. Kristine Ciardullo of the City of Brampton helped secure access to study sites; David Kenth of the City of Brampton was great assistance in locating appropriate stormwater wetlands and providing background on the realities of practical 
stormwater wetland management. This project was funded by a Natural Sciences and Engineering Research Council Discovery Grant (Canada).

\subsection{References}

Allison, S.D., Martiny, J.B.H., 2008. Resistance, resilience, and redundancy in microbial communities. Proc. Natl. Acad. Sci. 105, 11512-11519. doi:10.1073/pnas.0801925105

Åkerblom, S., Bishop, K., Björn, E., Lambertsson, L., Eriksson, T., Nilsson, M.B., 2013. Significant interaction effects from sulfate deposition and climate on sulfur concentrations constitute major controls on methylmercury production in peatlands. Geochim. Cosmochim. Acta 102, 1-11. doi:10.1016/j.gca.2012.10.025

Bachand, P.A.M., Bachand, S.M., Fleck, J.A., Alpers, C.N., Stephenson, M., Windham-Myers, L., 2014. Methylmercury production in and export from agricultural wetlands in California, USA: The need to account for physical transport processes into and out of the root zone. Sci. Total Environ. 472, 957-970. doi:10.1016/j.scitotenv.2013.11.086

Ballantine, K.A., Lehmann, J., Schneider, R.L., Groffman, P.M., 2015. Trade-offs between soil-based functions in wetlands restored with soil amendments of differing lability. Ecol. Appl. 25, 215225.

Brix, H., 1997. Do macrophytes play a role in constructed treatment wetlands? Water Sci. Technol. 35, 11-17. doi:10.1016/S0273-1223(97)00047-4

Bruland, G.L., Richardson, C.J., Daniels, W.L., 2009. Microbial and geochemical responses to organic matter amendments in a created wetland. Wetlands 29, 1153-1165. doi:10.1672/08-201.1

Canário, J., Caetano, M., Vale, C., Cesário, R., 2007. Evidence for elevated production of methylmercury in salt marshes. Environ. Sci. Technol. 41, 7376-7382. doi:10.1021/es071078j

Coleman Wasik, J.K., Engstrom, D.R., Mitchell, C.P.J., Swain, E.B., Monson, B.A., Balogh, S.J., Jeremiason, J.D., Branfireun, B.A., Kolka, R.K., Almendinger, J.E., 2015. The effects of hydrologic fluctuation and sulfate regeneration on mercury cycling in an experimental peatland: drought increases mercury in peatlands. J. Geophys. Res. Biogeosciences 120, 1697-1715. doi:10.1002/2015JG002993

Coleman Wasik, J.K., Mitchell, C.P.J., Engstrom, D.R., Swain, E.B., Monson, B.A., Balogh, S.J., Jeremiason, J.D., Branfireun, B.A., Eggert, S.L., Kolka, R.K., Almendinger, J.E., 2012. 
Methylmercury declines in a boreal peatland when experimental sulfate deposition decreases.

Environ. Sci. Technol. 46, 6663-6671. doi:10.1021/es300865f

Cosio, C., Flück, R., Regier, N., Slaveykova, V.I., 2014. Effects of macrophytes on the fate of mercury in aquatic systems: $\mathrm{Hg}$ and macrophytes. Environ. Toxicol. Chem. 33, 1225-1237.

doi:10.1002/etc.2499

Chiandet, A.S., Xenopoulos, M.A., 2016. Landscape and morphometric controls on water quality in stormwater management ponds. Urban Ecosystems. doi:10.1007/s11252-016-0559-8

Drake, J., Guo, Y. 2008. Maintenance of wet stormwater ponds in Ontario. Can. Wat. Resources J. 33:4 351-368

Drott, A., Lambertsson, L., Björn, E., Skyllberg, U., 2008. Do potential methylation rates reflect accumulated methyl mercury in contaminated sediments? Environ. Sci. Technol. 42, 153-158. doi:10.1021/es0715851

Duncan, C.P., Groffman, P.M. 1994. Comparing microbial parameters in natural and constructed wetlands. J. Environ. Qual., 23, 298-305.

Eckley, C.S., Branfireun, B., 2008. Mercury mobilization in urban stormwater runoff. Sci. Total Environ. 403, 164-177. doi:10.1016/j.scitotenv.2008.05.021

Environmental Protection Agency, 2009. Method 415.3 Determination of total organic carbon and specific UV absorbance at $254 \mathrm{~nm}$ in source water and drinking water, Revision 1.2 EPA/600/R09/122. Cincinnati, Ohio.

Feng, S., Ai, Z., Zheng, S., Gu, B., Li, Y., 2014. Effects of dryout and inflow water quality on mercury methylation in a constructed wetland. Water. Air. Soil Pollut. 225. doi:10.1007/s11270-014-19296

Fortin, D., Goulet, R., Roy, M., 2000. Seasonal cycling of Fe and S in a constructed wetland: the role of sulfate-reducing bacteria. Geomicrobiol. J. 17, 221-235.

Galloway, J.N., Aber, J.D., Erisman, J.W., Seitzinger, S.P., Howarth, R.W., Cowling, E.B., Cosby, B.J., 2003. The nitrogen cascade. Bioscience 53, 341-356.

Gilmour, C.C., Henry, E.A., Mitchell, R., 1992. Sulfate stimulation of mercury methylation in freshwater sediments. Environ. Sci. Technol. 26, 2281-2287.

Gilmour, C.C., Podar, M., Bullock, A.L., Graham, A.M., Brown, S.D., Somenahally, A.C., Johs, A., Hurt, R.A., Bailey, K.L., Elias, D.A., 2013. Mercury methylation by novel microorganisms from new environments. Environ. Sci. Technol. 47, 11810-11820. doi:10.1021/es403075t

Gionfriddo, C.M., Tate, M.T., Wick, R.R., Schultz, M.B., Zemla, A., Thelen, M.P., Schofield, R., Krabbenhoft, D.P., Holt, K.E., Moreau, J.W., 2016. Microbial mercury methylation in Antarctic sea ice. Nat. Microbiol. 1, 16127. doi:10.1038/nmicrobiol.2016.127 
Glover, J.B., Domino, M.E., Altman, K.C., Dillman, J.W., Castleberry, W.S., Eidson, J.P., Mattocks, M., 2010. Mercury in South Carolina fishes, USA. Ecotoxicology 19, 781-795. doi:10.1007/s10646009-0455-6

Goulet, R.R., Holmes, J., Page, B., Poissant, L., Siciliano, S.D., Lean, D.R.S., Wang, F., Amyot, M., Tessier, A., 2007. Mercury transformations and fluxes in sediments of a riverine wetland. Geochim. Cosmochim. Acta 71, 3393-3406. doi:10.1016/j.gca.2007.04.032

Hall, B.D., Louis, V.L.S., Rolfhus, K.R., Bodaly, R.A., Beaty, K.G., Paterson, M.J., Cherewyk, K.A.P., 2005. Impacts of reservoir creation on the biogeochemical cycling of methyl mercury and total mercury in boreal upland forests. Ecosystems 8, 248-266. doi:10.1007/s10021-003-0094-3

He, T., Lu, J., Yang, F., Feng, X., 2007. Horizontal and vertical variability of mercury species in pore water and sediments in small lakes in Ontario. Sci. Total Environ. 386, 53-64. doi:10.1016/j.scitotenv.2007.07.022

Hintelmann, H., Evans, R.D., 1997. Application of stable isotopes in environmental tracer studies Measurement of monomethylmercury $\left(\mathrm{CH}_{3} \mathrm{Hg}^{+}\right)$by isotope dilution ICP-MS and detection of species transformation. Fresenius J. Anal. Chem. 358, 378-385. doi:10.1007/s002160050433

Hintelmann, H., Keppel-Jones, K., Evans, R.D., 2000. Constants of mercury methylation and demethylation rates in sediments and comparison of tracer and ambient mercury availability. Environ. Toxicol. Chem. 19, 2204-2211.

Hintelmann, H., Ogrinc, N. 2003. Determination of stable mercury isotopes by ICP/MS and their application in environmental studies. ACS Symp. Ser., 835, 321-338.

Horvat, M.; Bloom, N.S.; Liang, L., 1993. Comparison of distillation with other current isolation methods for the determination of methyl mercury compounds in low level environmental samples. Part 1. Sediments. Anal. Chim. Acta. 281, 135-152.

Hsu-Kim, H., Kucharzyk, K.H., Zhang, T., Deshusses, M.A., 2013. Mechanisms regulating mercury bioavailability for methylating microorganisms in the aquatic environment: A critical review. Environ. Sci. Technol. 130227163055006. doi:10.1021/es304370g

Jeremiason, J.D., Engstrom, D.R., Swain, E.B., Nater, E.A., Johnson, B.M., Almendinger, J.E., Monson, B.A., Kolka, R.K., 2006. Sulfate addition increases methylmercury production in an experimental wetland. Environ. Sci. Technol. 40, 3800-3806. doi:10.1021/es0524144

Kadlec, R.H., Wallace, S. 2009. Treatment Wetlands. CRC Press, Taylor \& Francis Publishing, New York.

King, J.K., Harmon, S.M., Fu, T.T., Gladden, J.B., 2002. Mercury removal, methylmercury formation, and sulfate-reducing bacteria profiles in wetland mesocosms. Chemosphere 46, 859-870. 
Lehnherr, I., St. Louis, V.L., Kirk, J.L., 2012. Methylmercury cycling in high arctic wetland ponds: controls on sedimentary production. Environ. Sci. Technol. 46, 10523-10531. doi:10.1021/es300577e

Liebens, J., 2001. Heavy metal contamination of sediments in stormwater management systems: the effect of land use, particle size, and age. Environ. Geol. 41, 341-351. doi:10.1007/s002540100392

Lin, C.-C., Yee, N., Barkay, T., 2012. Microbial transformations in the mercury cycle. Environ. Chem. Toxicol. Mercury 155-191.

Little, M.E., Burgess, N.M., Broders, H.G., Campbell, L.M., 2015. Mercury in little brown bat (Myotis lucifugus) maternity colonies and its correlation with freshwater acidity in Nova Scotia, Canada. Environ. Sci. Technol. 49, 2059-2065. doi:10.1021/es5050375

Liu, Y.-R., Dong, J.-X., Han, L.-L., Zheng, Y.-M., He, J.-Z., 2016. Influence of rice straw amendment on mercury methylation and nitrification in paddy soils. Environ. Pollut. 209, 53-59. doi:10.1016/j.envpol.2015.11.023

Lovley, D.R., Klug, M.J., 1983. Sulfate reducers can outcompete methanogens at freshwater sulfate concentrations. Appl. Environ. Microbiol. 45, 187-192.

MacKinnon, J.G., White, H., 1985. Some heterosketastic-consistent covariance matrix estimators with improved finite sample properties. J. Economet. 29 305-325 doi: 10.1016/0304-4076(85)90158-7.

Mailman, M., Stepnuk, L., Cicek, N., Bodaly, R.A., 2006. Strategies to lower methyl mercury concentrations in hydroelectric reservoirs and lakes: A review. Sci. Total Environ. 368, 224-235. doi:10.1016/j.scitotenv.2005.09.041

Malaviya, P., Singh, A., 2012. Constructed wetlands for management of urban stormwater runoff. Crit. Rev. Environ.1 Sci. Technol. 42, 2153-2214. doi:10.1080/10643389.2011.574107

Meng, B., Feng, X., Qiu, G., Li, Z., Yao, H., Shang, L., Yan, H., 2016. The impacts of organic matter on the distribution and methylation of mercury in a hydroelectric reservoir in Wujiang River, Southwest China: The influence of organic matter on mercury cycling. Environ. Toxicol. Chem. 35, 191-199. doi:10.1002/etc.3181

Mitchell, C.P.J., Branfireun, B.A., Kolka, R.K., 2008. Spatial characteristics of net methylmercury production hot spots in peatlands. Environ. Sci. Technol. 42, 1010-1016. doi:10.1021/es0704986

Mitchell, C.P.J., Gilmour, C.C., 2008. Methylmercury production in a Chesapeake Bay salt marsh. J. Geophys. Res. 113, G00C04.

Miya, R.K., Firestone, M.K., 2001. Enhanced phenanthrene biodegradation in soil by slender oat root exudates and root debris. J. Environ. Qual. 30, 1911-1918. 
Munthe, J., Bodaly, R.A., Branfireun, B.A., Driscoll, C.T., Gilmour, C.C., Harris, R., Horvat, M., Lucotte, M., Malm, O., 2007. Recovery of mercury-contaminated fisheries. AMBIO J. Hum. Environ. 36, 33-44. doi:10.1579/0044-7447(2007)36[33:ROMF]2.0.CO;2

Ngugi, D.K., Blom, J., Stepanauskas, R., Stingl, U., 2016. Diversification and niche adaptations of Nitrospina-like bacteria in the polyextreme interfaces of Red Sea brines. ISME J. 10, 1383-1399.

Ontario Ministry of the Environment, 2003. Stormwater management planning and design manual. MOE, Toronto, Ont.

Oswald, C.J., Carey, S.K., 2016. Total and methyl mercury concentrations in sediment and water of a constructed wetland in the Athabasca Oil Sands Region. Environ. Pollut. 213, 628-637. doi:10.1016/j.envpol.2016.03.002

Podar, M., Gilmour, C.C., Brandt, C.C., Soren, A., Brown, S.D., Crable, B.R., Palumbo, A.V., Somenahally, A.C., Elias, D.A., 2015. Global prevalence and distribution of genes and microorganisms involved in mercury methylation. Sci. Adv. 1, e1500675-e1500675. doi:10.1126/sciadv.1500675

R Core Team, 2016. R: A language and environment for statistical computing. R Foundation for Statistical Computing, Vienna, Austria. https://www.R-project.org/.

Ravichandran, M., 2004. Interactions between mercury and dissolved organic matter-a review. Chemosphere 55, 319-331. doi:10.1016/j.chemosphere.2003.11.011

Reddy, R. K., Delaune, R. 2008. Biogeochemistry of wetlands: Science and Application. CRC Press, New York.

Regier, N., Frey, B., Converse, B., Roden, E., Grosse-Honebrink, A., Bravo, A.G., Cosio, C., 2012. Effect of Elodea nuttallii roots on bacterial communities and $\mathrm{MMHg}$ proportion in a $\mathrm{Hg}$ polluted sediment. PLOS ONE 7, e45565.

Roy, V., Amyot, M., Carignan, R., 2009. Beaver ponds increase methylmercury concentrations in Canadian Shield streams along vegetation and pond-age gradients. Environ. Sci. Technol. 43, 5605-5611. doi:10.1021/es901193x

Rumbold, D.G., Fink, L.E., 2006. Extreme spatial variability and unprecedented methylmercury concentrations within a constructed wetland. Environ. Monit. Assess. 112, 115-135.

Schallenberg, M. Kalff, J., 1993. The ecology of sediment bacteria in lakes and comparisons with other aquatic ecosystems. Ecology 74, 919-934.

Scholz, M., Lee, B., 2005. Constructed wetlands: a review. Int. J. Environ. Stud. 62, 421-447. doi:10.1080/00207230500119783

Shih, R., Robertson, W.D., Schiff, S.L., Rudolph, D.L., 2011. Nitrate controls methyl mercury production in a streambed bioreactor. J. Environ. Qual. 40, 1586. doi:10.2134/jeq2011.0072 
Sinclair, K.A., Xie, Q., Mitchell, C.P.J., 2012. Methylmercury in water, sediment, and invertebrates in created wetlands of Rouge Park, Toronto, Canada. Environ. Pollut. 171, 207-215. doi:10.1016/j.envpol.2012.07.043

Smith, S.V., Renwick, W.H., Bartley, J.D., Buddemeier, R.W., 2002. Distribution and significance of small, artificial water bodies across the United States landscape. Sci. Total Environ. 299, 21-36.

Stamenkovic, J., Gustin, M.S., Dennett, K.E., 2005. Net methyl mercury production versus water quality improvement in constructed wetlands: trade-offs in pollution control. Wetlands 25, 748-757.

St. Louis, V.L., Rudd, J.W.M., Kelly, C.A., Bodaly, R.A., Paterson, M.J., Beaty, K.G., Hesslein, R.H., Heyes, A., Majewski, A.R., 2004. The rise and fall of mercury methylation in an experimental reservoir. Environ. Sci. Technol. 38, 1348-1358. doi:10.1021/es034424f

Strickman, R.J.S., Fulthorpe, R.R., Coleman Wasik, J.K., Engstrom, D.R., Mitchell, C.P.J., 2016. Experimental sulfate amendment alters peatland bacterial community structure. Sci. Total Environ. 566-567, 1289-1296. doi:10.1016/j.scitotenv.2016.05.189

Taylor, G.D., Fletcher, T.D., Wong, T.H.F., Breen, P.F., Duncan, H.P., 2005. Nitrogen composition in urban runoff —implications for stormwater management. Water Res. 39, 1982-1989. doi:10.1016/j.watres.2005.03.022

Tjerngren, I., Karlsson, T., Björn, E., Skyllberg, U., 2011. Potential Hg methylation and MeHg demethylation rates related to the nutrient status of different boreal wetlands. Biogeochemistry 108, 335-350. doi:10.1007/s10533-011-9603-1

Todorova, S. G., Driscoll, C.T., Matthews, D.A., Effler, S.W., Hines, M.E., Henry, E. A. 2009. Evidence for regulation of monomethyl mercury by nitrate in a seasonally stratified, eutrophic lake. Environ. Sci. Technol. 43, 6572-6578.

Ullrich, S.M., Tanton, T.W., Abdrashitova, S.A., 2001. Mercury in the aquatic environment: A review of factors affecting methylation. Crit. Rev. Environ. Sci. Technol. 31, 241-293. doi:10.1080/20016491089226

Viollier, E., Inglett, P.., Hunter, K., Roychoudhury, A.., Van Cappellen, P., 2000. The ferrozine method revisited: $\mathrm{Fe}(\mathrm{II}) / \mathrm{Fe}(\mathrm{III})$ determination in natural waters. Appl. Geochem. 15, 785-790. doi:10.1016/S0883-2927(99)00097-9

Vymazal, J., 2007. Removal of nutrients in various types of constructed wetlands. Sci. Total Environ. 380, 48-65. doi:10.1016/j.scitotenv.2006.09.014

Weishaar, J.L., Aiken, G.R., Bergamaschi, B.A., Fram, M.S., Fujii, R., Mopper, K., 2003. Evaluation of specific ultraviolet absorbance as an indicator of the chemical composition and reactivity of dissolved organic carbon. Environ. Sci. Technol. 37, 4702-4708. doi:10.1021/es030360x 
Windham-Myers, L., Fleck, J.A., Ackerman, J.T., Marvin-DiPasquale, M., Stricker, C.A., Heim, W.A., Bachand, P.A.M., Eagles-Smith, C.A., Gill, G., Stephenson, M., Alpers, C.N., 2014. Mercury cycling in agricultural and managed wetlands: A synthesis of methylmercury production, hydrologic export, and bioaccumulation from an integrated field study. Sci. Total Environ. 484, 221-231. doi:10.1016/j.scitotenv.2014.01.033

Windham-Myers, L., Marvin-Dipasquale, M., Krabbenhoft, D.P., Agee, J.L., Cox, M.H., HerediaMiddleton, P., Coates, C., Kakouros, E., 2009. Experimental removal of wetland emergent vegetation leads to decreased methylmercury production in surface sediment. J. Geophys. Res. 114. doi:10.1029/2008JG000815

Wolf, K.L., Ahn, C., Noe, G.B., 2011. Development of Soil Properties and Nitrogen Cycling in Created Wetlands. Wetlands 31, 699-712. doi:10.1007/s13157-011-0185-4 


\section{Chapter 4}

\section{Experimental sulfate amendment alters peatland bacterial community structure}

This chapter is reproduced as published in Science of the Total Environment (Strickman, R.J., Fulthorpe, R.R., Coleman Wasik, J.K., Engstrom, D.R., Mitchell, C.P.J., 2016. Experimental sulfate amendment alters peatland bacterial community structure. Sci. Total Environ. http://dx.doi:10.1016/j.scitotenv.2016.05.189). Reproduced with permission from Science of the Total Environment. 


\subsection{Abstract}

As part of a long-term, peatland-scale sulfate addition experiment, the impact of varying sulfate deposition on bacterial community responses was assessed using $16 \mathrm{~S}$ tag encoded pyrosequencing. In three separate areas of the peatland, sulfate manipulations included an eight year quadrupling of atmospheric sulfate deposition (experimental), a 3-year recovery to background deposition following 5 years of elevated deposition (recovery), and a control area. Peat concentrations of methylmercury ( $\mathrm{MeHg}$ ), a bioaccumulative neurotoxin, were measured, the production of which is attributable to a growing list of microorganisms, including many sulfate-reducing Deltaproteobacteria. The total bacterial and Deltaproteobacterial community structures in the experimental treatment differed significantly from those in the control and recovery treatments that were either indistinguishable or very similar to one another. Notably, the relatively rapid return (within three years) of bacterial community structure in the recovery treatment to a state similar to the control, demonstrates significant resilience of the peatland bacterial community to changes in atmospheric sulfate deposition. Changes in $\mathrm{MeHg}$ accumulation between sulfate treatments correlated with changes in the Deltaproteobacterial community, suggesting that sulfate may affect $\mathrm{MeHg}$ production through changes in the community structure of this group.

\subsection{Introduction}

Atmospheric sulfate deposition may exert a significant impact on bacterial community structure and activity in anoxic, aquatic ecosystems. Sulfate is an electron acceptor for sulfate reducing bacteria (SRB), whose by-products affect the growth of other metabolic guilds including sulfide oxidizers and, under some conditions, methanogens (Muyzer and Stams, 2008; Pester, 2012). Peatlands, which extend over more than four million square kilometers and store up to $30 \%$ of the world's soil carbon (Limpens et al., 2008), host diverse and active communities of SRB, even in the upper, periodically unsaturated layers (Schmalenberger et al., 2007) that are the most exposed to atmospheric inputs. Although changes in sulfate deposition have the potential to alter interactions among peatland bacteria, and thus affect major biogeochemical cycles and ecosystem functioning (Fuhrman 2009), sulfate as a bacterial driver has been little studied in comparison to the effects of other atmospherically deposited nutrients on bacterial communities 
(Andersen et al., 2013). Previous investigations have focused on very broad taxonomic or metabolic divisions, and indicate an increase in gram-negative bacteria (Pennanen et al., 1998), stimulation of SRB paired with inhibition of methanogens (Gauci and Chapman, 2006; Vile et al., 2003), or similarities in the diversity of a limited number of SRB from sites that received similar levels of nutrients, including sulfate (Steger et al., 2011). Here high-throughput DNA sequencing was used to investigate the influence of sulfate on the peatland bacterial community as a whole.

The response of bacterial communities to disturbance, including changes in atmospheric nutrient supply, is an important and variable aspect of bacterial ecology (Griffiths and Philippot, 2012). Bacterial communities may resist or rapidly recover from some disturbances (Allison and Martiny, 2008), while in other circumstances a disturbance may trigger a long-term change in bacterial community structure (McKew et al., 2011; Nelson et al., 2015) or functioning (Currey et al., 2009), analogous to a shift to an alternative stable state (Scheffer et al., 2001). In a shortterm experimental manipulation of sulfate deposition in an ombrotrophic peatland, slight shifts in microbial enzyme activities were observed in an area of the peatland recovering from sulfate additions (Seifert-Monson et al., 2014), but the effects of sulfate on bacterial community structure remain unknown.

In much of Europe and North America, atmospheric deposition of sulfate has greatly increased since the onset of the industrial revolution (Mayewski et al., 1990), although stricter emissions regulations introduced in the 1980s have substantially decreased sulfate deposition in these same regions (Kahl et al., 2004). Sulfate deposition to aquatic systems such as lakes and wetlands is of particular significance because it has been repeatedly observed to increase levels of methylmercury $(\mathrm{MeHg})$. $\mathrm{MeHg}$ is a bioaccumulative neurotoxin that is produced by bacteria in permanently or transiently anoxic aquatic environments (Branfireun et al., 1990; Coleman Wasik et al., 2012; Munthe et al., 2007). Peatlands are a wetland type wherein particularly high production and accumulation of $\mathrm{MeHg}$ is often observed in periodically inundated near-surface layers (Mitchell et al., 2008). Mercury (Hg) methylation ability has been confirmed in many Deltaproteobacterial SRB (Gilmour et al., 2013; Ranchou-Peyruse et al., 2009), and experimental sulfate additions have been shown to increase $\mathrm{MeHg}$ concentrations via metabolic stimulation of SRB (Gilmour et al., 1992; Yu et al., 2010). However, outside of the direct 
metabolic stimulation of SRB, it is not known if sulfate-mediated changes in bacterial community structure relate to net $\mathrm{MeHg}$ production, which could potentially occur via syntrophic interactions between methylating and nonmethylating taxa (Bae et al., 2014; Pak and Bartha, 1998).

In this study, the in situ response of the bacterial community of a sub-boreal peatland in Minnesota to relatively long-term experimental increases and decreases in sulfate deposition, along with the associated changes in $\mathrm{MeHg}$ concentrations, was assessed. The primary objective here was to assess how changing sulfate loading influences the composition of the peatland bacterial community, with a secondary aim to determine if any relationship exists between $\mathrm{MeHg}$ accumulation within the peat and bacterial community structure. It is hypothesized that increased sulfate loading will lead to significant changes in the peatland bacterial community composition. Given the relatively rapid declines in $\mathrm{MeHg}$ concentrations observed by Coleman Wasik et al. (2012) once experimental sulfate additions were ceased in this same study wetland, it is hypothesized that the bacterial community structure will also change relatively rapidly with decreased sulfate loading and that changes in bacterial community structure can be related to changes in $\mathrm{MeHg}$ accumulation and loss.

\subsection{Experimental Procedures}

\subsubsection{Site Description and Experimental Design}

An 8-year manipulation of an experimental sub-boreal peatland in the Marcell Experimental Forest, Minnesota $\left(47^{\circ} 32^{\prime} \mathrm{N}, 93^{\circ} 28^{\prime} \mathrm{W}\right)$ simulated realistic increases in sulfate deposition as well as recovery from augmented sulfate deposition, and the impact of these changes on net $\mathrm{MeHg}$ accumulation (Coleman Wasik et al., 2012, 2015; Jeremiason et al., 2006). The peatland, referred to as "S6", covers approximately 2.4 ha and includes an ombrotrophic, elongate, 10-25 m wide center (bog) with Sphagnum hummocks and an overstory of tamarack (Larix lariciana) and black spruce (Picea mariana). The bog has a 2-10 m wide margin (lagg) vegetated with alders (Alnus rugosa) and willows (Salix spp.; Figure 4.1). In addition to direct precipitation inputs, the lagg intermittently receives water via shallow interflow from a surrounding 6.5 ha upland forest, whereas the bog area is precipitation fed only (Mitchell et al., 2009). Sulfate deposition to a 
portion of the $\mathrm{S} 6$ peatland was experimentally increased by $\sim 4 \mathrm{x}$ over ambient rates in order to simulate the deposition received by areas in the northeastern US and eastern Canada before strict emissions regulations came into effect in the 1980s. Source water for the additions was obtained from a dilute (conductivity $\sim 10 \mu \mathrm{S} \mathrm{cm}^{-1}$ ), low mercury $\left(\mathrm{Hg}<1 \mathrm{ng} \mathrm{l}^{-1}\right.$ ) ombrotrophic pond in an adjacent watershed and amended with concentrated sodium sulfate to a final sulfate concentration of $\sim 200 \mathrm{mg} \mathrm{l}^{-1}$, as described previously in Jeremiason et al. (2006) and Coleman Wasik et al. (2012). From spring of 2001 to fall of 2008, this system was used to deliver $32 \mathrm{~kg}$ $\mathrm{ha}^{-1} \mathrm{yr}^{-1}$ of sulfate to both the bog and lagg areas of an experimental section of the wetland via a PVC pipe sprinkler system during 3-4 simulated rainfall events $(6-10 \mathrm{~mm})$ per year. An unamended area of the peatland, hydrologically up-gradient of the experimental area, was maintained as a control (Figure 4.1). In 2006, sulfate additions to the up-gradient one-third of the experimental section ended, creating a recovery treatment subject only to an average background deposition rate of $4.6 \mathrm{~kg} \mathrm{ha}^{-1}$ (NADP, 2006). Additions to the downstream two-thirds of the experimental section continued through the end of 2008 with a final sulfate amendment in October. In addition to this three-level sulfate amendment factor (experimental, recovery, and control), the natural topography of the peatland created another two-level factor (ombrotrophic bog area versus the slightly more minerotrophic lagg area), for a total of six treatments (Figure 4.1) that could be sampled to compare the effects of sulfate deposition on the bacterial community as well as the concentration of MeHg in the peat. In late-May 2009, a period when the water table was above the peat surface, three peat cores were collected in each of the six treatment areas described above, with each core serving as a replicate. From each of these eighteen cores, peat was collected from the $2-4 \mathrm{~cm}$ depth interval and kept frozen until analysis. Peat samples from each core were split into two subsamples for analyses of 1) bacterial community composition and 2) total $\mathrm{Hg}$ ( $\mathrm{THg}$ ) and $\mathrm{MeHg}$ concentrations, according to methods described below. 


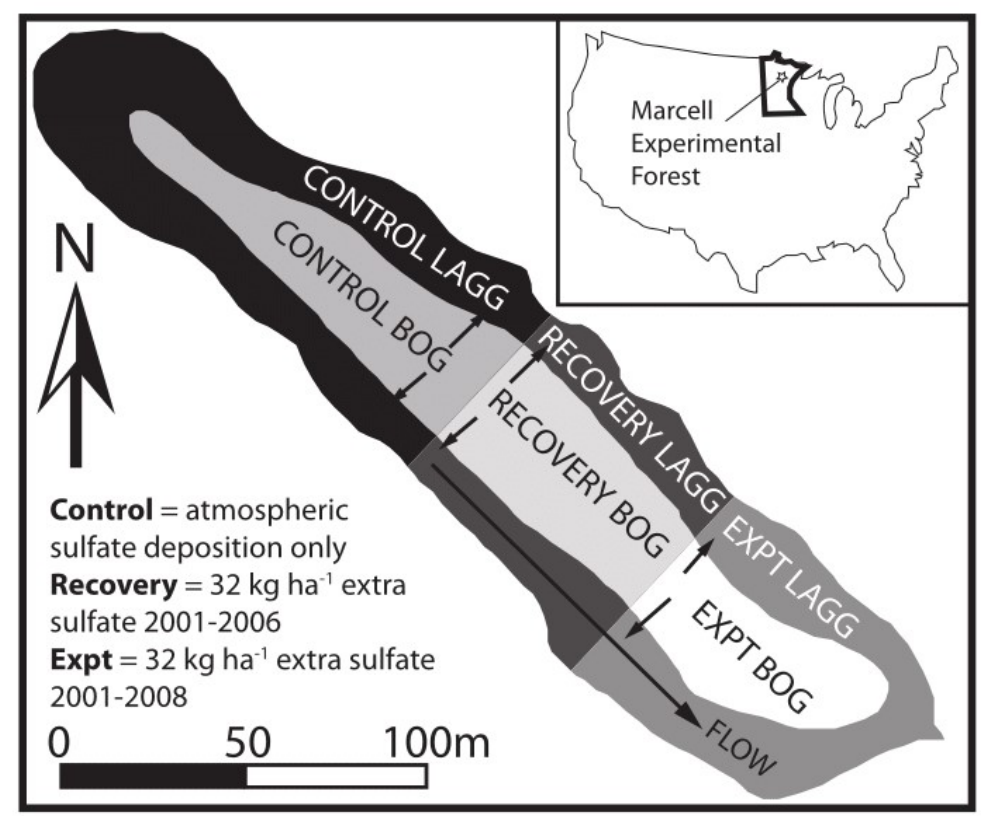

Figure 4.1 Field Site: Diagram of the sulfate amendment experiment in the S6 peatland of the Marcell Experimental Forest. Black arrows indicate the direction of water flow. Inset map indicates location of the Marcell Experimental Forest in north-central Minnesota, U.S.A. Sulfate amendment schedule is summarized in the lower left corner for reference.

\subsubsection{Bacterial analyses}

\subsubsection{DNA extraction and sequencing}

Total community genomic DNA was extracted from each of the three replicate samples from all six treatment areas (18 samples total). Using the MoBio PowerSoil ${ }^{\mathrm{TM}}$ DNA Extraction Kit (MO BIO Laboratories, Solana Beach, CA, USA), DNA was extracted from $0.25 \mathrm{~g}$ of thawed peat according to the manufacturer's instructions. An Eppendorf Nanodrop 1000 (Thermo Scientific) was used to estimate DNA concentration (ng $\left.\mu 1^{-1}\right)$ and purity (260/280 and 260/230 ratios). These eighteen samples were subjected to pyrosequencing of bacterial $16 \mathrm{~S}$ ribosomal gene amplicon. The hypervariable V1-V3 region was targeted using 28f (5'-

GAGTTGATCNTGGTCAG-3') and 519r (5'-GTNTTACNGCGGCKGCTG-3') (Amann et al., 1995) by bTEFAP (bacterial tag encoded FLX amplicon pyrosequencing), carried out by Research and Testing Inc. (Lubbock, Texas) on a Roche 454 FLX Titanium genome sequencer. 
Sequences were processed using Qiime 1.4.0. (Caporaso et al., 2010). Samples were demultiplexed, forward and (if present) reverse primers were trimmed. Low quality samples were identified and filtered out using the default parameters. Sequences were chimera filtered and denoised using OTUpipe with USEARCH (Edgar, 2010) and both de novo and database (GOLD) based chimera filtering with intersection; MINSIZE was 2. Sequences were assigned to operational taxonomic units (OTUs) at an identity threshold of 97\% (Kunin et al., 2010) using the RDP method trained on the Feb 4, 2011 release of Greengenes with default settings. Sequences were aligned using PYNAST trained against the 2011 release of the Greengenes core set, and a phylogenetic tree constructed with FASTTREE algorithm (Price et al., 2010) and default settings. To allow comparison of community compositions between samples that returned different numbers of reads, all community analyses were carried out on weighted abundances, calculated as the number of reads per OTU in a given sample divided by the total number of reads for that sample.

\subsubsection{Sequence accession numbers}

All sequences that passed quality control steps and were included in the analysis were deposited to the EMBL-EBI database under accession numbers ERS452350-ERS452367.

\subsubsection{Sequence analysis}

To assess the impact of the varying sulfate treatments on the bacterial community, weighted UNIFRAC distance matrices, a phylogenetically aware beta diversity metric designed for analysis of large genomic datasets (Lozupone and Knight, 2005), were used to compare the relatedness of bacterial community composition from different treatments. Based on differences in hydrology and nutrient status (Mitchell et al., 2008), the bacterial communities of lagg and bog sites were analyzed separately. Hierarchical clustering was applied to UNIFRAC matrices to visualize patterns of relatedness between bacterial communities (Hamady et al., 2009), and PERMANOVA (permutational analysis of variance) to assess the significance of the revealed patterns (Anderson, 2001; McArdle and Anderson, 2001). Alpha diversity was assessed using the Chao1 diversity index, which estimates the true diversity of a population by extrapolating from the abundance distribution of the subsample (Chao, 1984). Mantel tests were used to test 
correlations between bacterial community structures and peat $\mathrm{MeHg}$ content. These tests were conducted in Qiime with 999 permutations at $\alpha<0.05$. In addition, the Deltaproteobacteria, which host many SRB and confirmed mercury methylators, were separately assessed for the relationship of their community structure to sulfate amendment and \% $\mathrm{MeHg}$ (percent of $\mathrm{THg}$ as $\mathrm{MeHg}$ ) via the same methods used for the whole bacterial community. Two-tailed tests of Pearson's correlations at $\alpha \leq 0.01$ were used to relate specific OTUs with $\% \mathrm{MeHg}$ in peat.

\subsubsection{Chemical Analyses}

As for the bacterial community analyses, one peat sample was analyzed from each of three cores collected from each of the six treatment areas, yielding 18 samples. THg analysis in peat samples was carried out via microwave digestion in concentrated $\mathrm{HNO}_{3}$, cold-vapor generation (using $\mathrm{SnCl}_{2}$ ), dual gold-trap amalgamation, and detection by cold vapor atomic fluorescence spectroscopy (CVAFS) on a Tekran 2600 total-Hg analyzer. MeHg analysis was carried out via isotope dilution-gas chromatography-inductively coupled plasma mass spectrometry (ID-GCICPMS) after the method of Hintelmann et al. (1997). Samples were enriched with a known spike of $\mathrm{Me}^{199} \mathrm{Hg}$ and distilled in $8 \mathrm{M} \mathrm{H}_{2} \mathrm{SO}_{4}$ and $20 \% \mathrm{KCl}$ in acid-cleaned Teflon vessels (Horvat et al., 1993). MeHg in distillates was liberated from solution through aqueous phase ethylation with sodium tetraethylborate, concentrated on a Tenax trap, thermally desorbed in a stream of argon gas, and passed through a heated chromatography column hyphenated to an Agilent Technologies 7700x ICP-MS machine. Blanks, duplicates, and certified reference materials (MESS-3 for THg; IAEA-405 for MeHg) were used for ongoing quality control (Table 7.2.1). Porewater for sulfate analysis was collected using a mini Teflon piezometer and peristaltic pump, and analyzed using a Dionex DX-500 ion chromatograph with standard methods (Coleman Wasik et al., 2012). Porewater sulfate concentrations were assessed once per treatment in 2009 at the time of core collection and interpretations were supplemented with historical data taken from the treatment areas by Coleman Wasik et al. (2012 and 2015). 


\subsection{Results and Discussion}

\subsubsection{Sulfate Deposition Manipulation Effects}

In this same peatland, experimental increases in sulfate deposition resulted in peak pore water sulfate concentrations $\left(3.8 \pm 2.2 \mathrm{mg} \mathrm{l}^{-1}\right.$ in 2008) immediately following experimental additions, declining significantly over a period of approximately two weeks, but with concentrations remaining elevated above those observed in the control (Coleman Wasik et al., 2012, 2015). Sulfate concentrations in the recovery treatment porewaters declined to levels similar to those in the control $\left(<1 \mathrm{mg} \mathrm{l}^{-1}\right)$ by early 2006 , the first year without experimental sulfate addition to the recovery treatment area, although sulfate release after drought events continued to be elevated in the recovery treatment area for the remainder of the study, suggesting that strong internal sulfur cycling persisted in the recovery treatment area and likely through the time that samples from this study were collected (Coleman Wasik et al., 2012, 2015). Sulfate reduction is clearly sulfatelimited in this peatland, with relatively rapid conversion of sulfate to sulfide and subsequent accumulation into the reduced and organic sulfur pools within the peat (Coleman Wasik et al., 2012). During porewater sampling in spring 2009, concomitant with peat collection for this study, sulfate concentrations were highest in the experimental treatment in both bog $\left(2.99 \mathrm{mg} \mathrm{1^{-1 } )}\right.$ and lagg (1.57 $\left.\mathrm{mg} \mathrm{l}^{-1}\right)$ areas and lowest in the control treatment area (bog: $1.09 \mathrm{mg} \mathrm{l}^{-1}$, lagg: 0.98 $\mathrm{mg}^{-1}$ ) with recovery area levels nearly identical to concentrations in the control area (Figure 4.2). Due to difficulty in collecting porewaters, only a single measurement was collected in each treatment, but the overall pattern of sulfate levels closely mirrors the long-running patterns observed in this experimental system (Coleman Wasik et al., 2012, 2015). These results were extensively explored by Coleman Wasik et al. $(2012,2015)$ and suggest that the sulfur cycle in the experimental area was significantly altered by sulfate additions, whereas sulfur cycling in the recovery area had more closely returned to pre-disturbance conditions. 


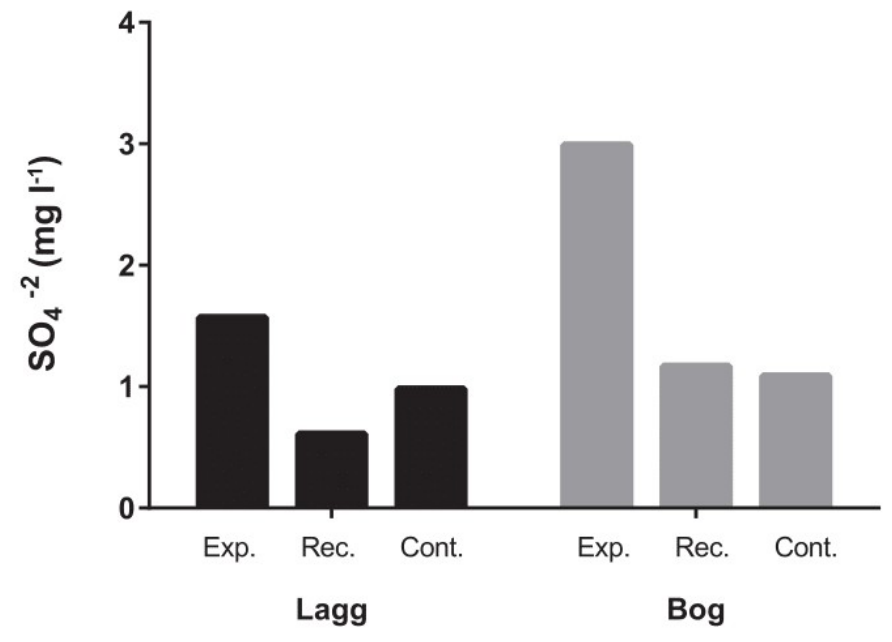

Figure 4.2 Sulfate Concentrations: sulfate levels $\left(\mathrm{mg} \mathrm{l}^{-1}\right)$ in porewater from the experimental (Exp.) recovery (Rec.) and control (Cont.) treatments of the lagg and bog areas of the S6 peatland five months after the final sulfate amendment in 2008.

\subsubsection{Bacterial Community Description}

A total of 241700 raw sequences were obtained from 18 core samples, 44038 of which were removed due to low read quality or during sample denoising and chimera filtering, leaving 197662 high quality sequences (8662 - 13110 per sample). Sequences clustered into 7050 operational taxonomic units (OTUs). Between 1480 and 2270 OTUs were obtained from each sample. The bacterial communities of the S6 peatland were diverse and harbored many rare taxa. Of the final 7050 OTUs, 29 were not of bacterial origin and 916 could not be assigned past the rank of Bacteria. Thirty phyla, 63 identified classes, 86 identified orders, and 109 identified families were represented in the sequences. Of the 5497 OTUs that could be assigned to the order level, 978 were placed into undescribed novel orders. Undescribed families made up 40\% (1936) of the 4889 OTUs that could be assigned to this level. Sixteen phyla were rare, representing less than $1 \%$ of any sample and 12 were completely absent from at least one treatment. The most abundant phylum was Proteobacteria, representing on average $30-52 \%$ of the weighted total community in each treatment, which included the classes Alphaproteobacteria (21-36\%), Betaproteobacteria (0.10-3.0\%), Deltaproteobacteria (2.5-6.6\%),

Gammaproteobacteria (3.6-7.6\%) and unassigned Proteobacteria (0.31-1.1\%). Thirteen other phyla represented on average more than $1 \%$ of the total community in any treatment (Figure 
4.3a), with the most commonly detected families being Acidobacteraceae, Bradyrhizobiaceae, Hyphomicrobiaceae, two other undefined families in Rhizobiales, and Acetobacteraceae in Rhodospiralles (Supplementary Tables 7.1.2-7.1.5). Overall, both bog and lagg bacterial communities were similar in terms of taxonomic composition and the relative abundances of phyla to other communities retrieved from Sphagnum peatlands around the northern hemisphere (Dedysh et al., 2006; Juottonen et al., 2005; Lin et al., 2012; Pankratov et al., 2005; Serkebaeva et al., 2013). Species richness, estimated using the Chaol index, was consistently and significantly (ANOVA; $\mathrm{F}=14.76, \mathrm{p}=0.002)$ higher in the lagg sites $(2704 \pm 197$ OTUs) than the bog sites (2338 \pm 341 OTUs). The control treatment also had significantly greater species diversity ( $2747 \pm 221$ OTUs) than the experimental ( $2392 \pm 217$ OTUs, $p=0.026)$ or recovery ( $2425 \pm 426$ OTUs, $p=0.043)$ treatments, which did not significantly differ from one another. Notably, the Desulfovibrionaceae and Syntrophobacteraceae that contain sulfate-reducing taxa, made up only a small fraction (0.00-0.0025\%; Supplementary Table 7.1.4) of the whole community, and did not differ significantly among treatments in either bog or lagg areas. 


\section{a) Total community}

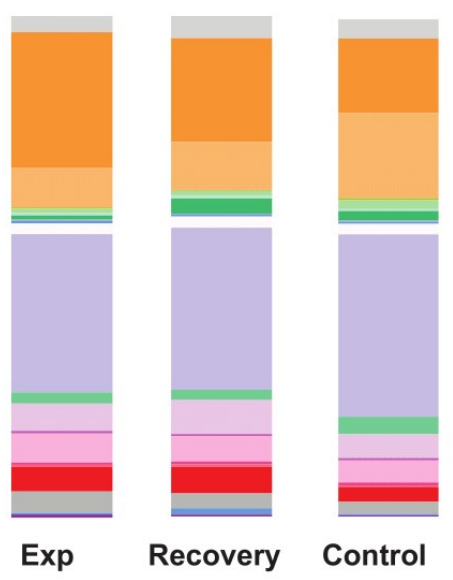

Lagg

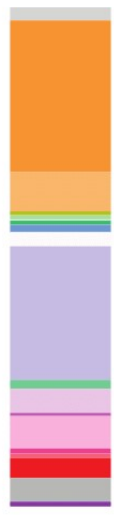

Exp

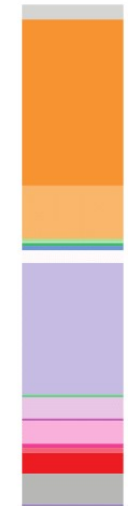

Recovery

Bog

\section{b) Deltaproteobacteria}

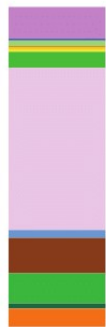

Exp

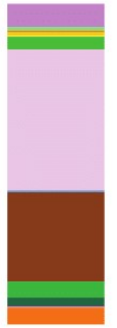

Recovery

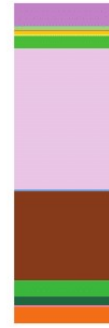

Control

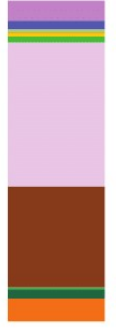

Exp

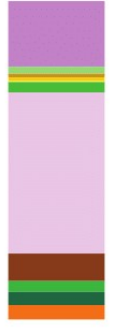

Recovery
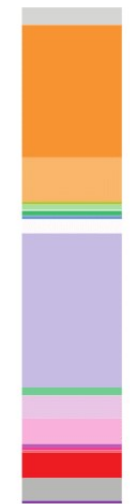

Control
Bacteria

- Actinobacteria

- Acidobacteria

- Armatimonadetes

- Bacteriodetes

- Chlorobi

- Chloroflexi

- Elusimicrobia

- Firmicutes

- Gemmatimonadales

Planctomyctes

- Alphaproteobacteria

- Betaproteobacteria

- Deltaproteobacteria

- Gammaproteobacteria

- Proteobacteria other

- TM7

- TM6

- Verruocomicrobia

W WPS-2

- AD3

Lagg

\section{Bog}

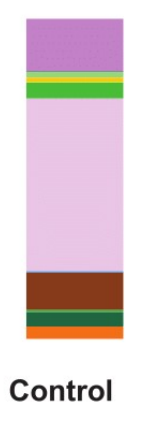
M1Z46
- Desulfovibrionales
- Deltaproteobacteria
- Syntrophorhabdaceae
- Bdellovibrionaceae
CTD005-82B-02
- Geobacteracea
Myxococcales
- Myxococcales: Cystobacteraceae
Myxococcales: Haliangiaceae
Myxococcaceae
- Polyangiaceae
- Syntrophobacterales
Syntrophaceae
- Syntrophobacteraceae

Figure 4.3 Bacterial Communities: Taxonomy and average relative abundance in each treatment from the lagg (left) and bog (right) areas for the total bacterial community (a) and the Deltaproteobacteria (b). Phyla level results are presented for the overall bacterial community, with low abundance phyla (less than $0.5 \%$ of the weighted abundance in any treatment) subsumed into the Bacteria classification for clarity. In phylum Proteobacteria, Alpha-, Beta-Gamma-, Delta-, and Epsilonproteobacteria are displayed separately. In Figure 4.3b, Deltaproteobacterial taxa are weighted by the relative abundance within the Deltaproteobacteria rather than the whole bacterial community and are presented at the lowest taxonomic level (phylum, class, or order) to which they could be assigned. 


\subsubsection{Bacterial Community Responses to Sulfate Amendment}

The experimental manipulation of sulfate deposition had a significant impact on the composition of the whole bacterial community within the peatland. PERMANOVA analysis revealed that the lagg zone communities differed significantly among treatments $\left(\mathrm{F}_{(2,6)}=3.65, \mathrm{p}=0.003\right)$. Hierarchical clustering analysis showed the recovery and control communities to be most similar, while the experimental communities were distinct (Figure 4.4a). In the bog areas, although the community clustering was visually less distinct than in the lagg (4b), bacterial communities did differ significantly among sulfate treatments $\left(\mathrm{F}_{(2,6)}=1.99, \mathrm{p}=0.019\right)$. The significantly greater taxonomic diversity of the lagg community suggests that it has a greater degree of ecological redundancy within functional groups, leading to greater resilience to sulfate perturbation than the bog community (Luck et al., 2003). In both lagg and bog areas, recovery and control Deltproteobacterial communities were highly similar to each other, but distinct from Deltproteobacterial communities in the experimental treatments. There was a composite cluster of communities from control and recovery treatments and a distant cluster composed solely of experimental communities (Figure 4.4c, d). These patterns were similar and significant in both $\operatorname{lagg}\left(\mathrm{F}_{(2,6)}=3.600 \mathrm{p}=0.003\right)$ and $\operatorname{bog}\left(\mathrm{F}_{(2,6)}=3.138, \mathrm{p}=0.006\right)$ areas.

The only previous work to investigate the effect of sulfate on an entire peatland bacterial community, rather than a metabolic or taxonomic subset, inferred changes in bacterial community structure by assessing changes in populations of bacterivorous testate amoebae (Payne et al., 2009). This indirect approach suggested that sulfate changed the bacterial community structure, a finding confirmed here using a replicated experimental manipulation of sulfate, paired with direct characterization of the bacterial community. The mechanism by which sulfate alters the peatland bacterial community appears to be relatively subtle, and further investigations are needed to link changes in the deposition of sulfate with specific taxonomic and functional changes. It is beyond the scope of this study to explain conclusively how sulfate changes bacterial communities; however, despite the apparent low abundance and responsiveness of confirmed SRB to sulfate treatments, results indicate that sulfate may directly alter the bacterial community structure through its effect on organisms that use it in their metabolism. Experimental sulfate additions may have stimulated unknown sulfate reducers, the 
full diversity of which is not described (Pester, 2012; Steger et al., 2011), or conferred a competitive advantage upon rare but disproportionately dominant sulfate reducers that have been estimated to carry out up to $50 \%$ of the anaerobic carbon mineralization in peatlands (Blodau et al., 2007; Keller and Bridgham, 2007), even when their abundance is very low (Andersen et al., 2013). Alternatively, it has been previously observed that changes in atmospheric sulfate inputs can restructure the bacterial community indirectly via mechanisms such as redirection of carbon flow away from methanogens (Gauci and Chapman, 2006; Lovley and Klug, 1983) with accompanying negative effects on methanotrophs, as well as stimulation of sulfide oxidizers as they consume the $\mathrm{H}_{2} \mathrm{~S}$ produced by sulfate reduction. Such a redirection of carbon flow with associated restructuring may be occurring in this system.

The effects of altered sulfate deposition regime on the bacterial community appear to be relatively short-lived and reversible. The recovery of bacterial communities in the lagg and near recovery in the bog within three years of the cessation of sulfate amendments suggests that the bacterial community structure is resilient to changes in the supply of labile sulfur. Similar findings were obtained by Seifert-Monson et al. (2014), who compared microbial enzyme activities in the former experimental area of the $\mathrm{S} 6$ peatland with newer microcosm sulfate amendments in the recovery and control areas. These authors observed no differences in enzyme activity between the former experimental area, which was in the process of recovering from sulfate amendment, and unamended control microcosms. At the time these authors sampled the S6 peatland, the experimental area had been unamended for approximately three years and was better considered a recovery treatment, suggesting that its microbial community was now functionally similar to that of the recovery treatment at the time it was sampled for this current study. In this experimental environment, added sulfate becomes increasingly recalcitrant as it is repeatedly recycled and progressively converted to less bioavailable organic forms (Coleman Wasik et al., 2012, 2015). Thus, most alterations to ecosystem function as a result of sulfatemediated changes in the bacterial community are hypothesized to be reversible on the timescale of a few years, although it should be noted that when sulfate deposition has been elevated for a longer time, the recovery period is also likely to be longer. This study specifically simulated the effects of historical reductions in sulfate deposition and suggests that emission reductions in North America and Europe over the last few decades have likely been sufficient for the peatland 
microflora to return to a structure similar to that found in areas with lower deposition.
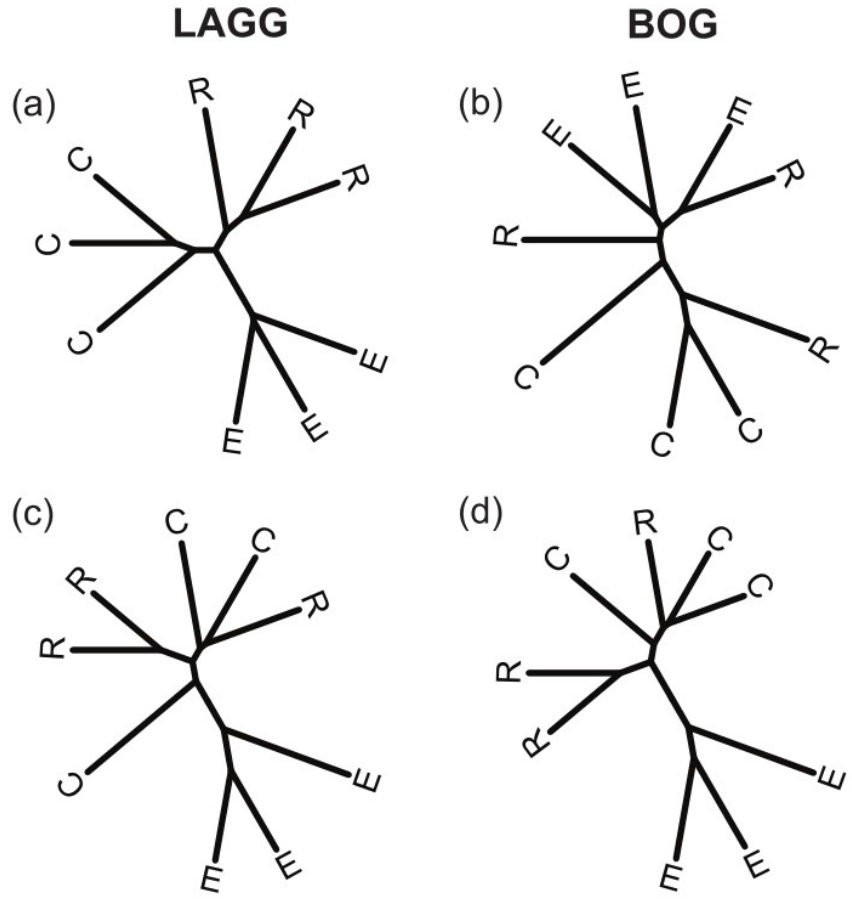

Figure 4.4 Clustering of Bacterial Communities: weighted-UNIFRAC based hierarchical clustering trees of bacterial communities sequenced from peat cores obtained from different sulfate amendment treatments $(\mathrm{E}=$ experimental; $\mathrm{R}=$ recovery; $\mathrm{C}=\mathrm{control})$ From top left: overall bacterial communities from the lagg (a) and bog (b) areas, and Deltaproteobacterial communities of the lagg (c) and bog (d).

\subsubsection{Relationship Between Sulfate-Mediated Changes in Bacterial Community Structure and MeHg}

The major purpose of this study was to investigate the impact of sulfate on the peatland bacterial community. However, the controlled field manipulation was originally conceived as an experimental investigation into the long-term effects of sulfate on MeHg production (Jeremiason et al., 2006), presenting an opportunity to explore whether bacterial community structure was related to $\% \mathrm{MeHg}$ in the peat. The percentage of mercury present as $\mathrm{MeHg}(\% \mathrm{MeHg})$ in peat integrates the long-term methylation and demethylation capacity of a soil, representing net $\mathrm{MeHg}$ accumulation (Drott et al., 2008). \%MeHg values correlated significantly with $\mathrm{MeHg}(r=$ $0.900, \mathrm{p}<0.001)$, but not $\mathrm{THg}(r=-0.071, \mathrm{p}=0.781)$ concentrations in the peat, indicating that differences in $\% \mathrm{MeHg}$ are related to $\mathrm{MeHg}$ production and/or accumulation in peat and not a 
function of inorganic Hg content. As described more fully in previous work (Coleman Wasik et al., 2012, 2015; Jeremiason et al., 2006), sulfate deposition history did alter $\mathrm{MeHg}$ concentrations and \% $\mathrm{MeHg}$ in both the bog and the lagg areas (bog: $\mathrm{F}_{(2,6)}=20.16, \mathrm{p}=0.002$, lagg: $\left.\mathrm{F}_{(2,6)}=9.477, \mathrm{p}=0.014\right) . \% \mathrm{MeHg}$ was elevated in peat samples from both the bog and lagg areas of the experimental treatment $(8-16 \%)$, intermediate in the bog and lagg areas of the recovery treatments $(3-7 \%)$, and lowest in the control treatment in the bog area $(1-3 \%)$ (Figure 4.5). In the bog area, $\% \mathrm{MeHg}$ in the experimental treatment differed significantly from that in both the recovery and control, while the control and recovery were statistically similar to one another. In the lagg area, the experimental treatment had significantly greater $\% \mathrm{MeHg}$ than the recovery treatment, but the control site had unexpectedly high \% $\mathrm{MeHg}(9-10 \%$; Figure 4.5). This discrepancy was likely due to sampling a natural MeHg "hot spot" within the control area, as previously described by Mitchell et al. (2008) and Coleman Wasik et al. (2012).

No correlation was found between the entire bacterial community structure and \% $\mathrm{MeHg}$ for either the lagg $(r=0.27, \mathrm{p}=0.10)$ or bog $(r=-0.13, \mathrm{p}=0.53)$ areas. Although both mercury methylation and sulfate reduction capacity are found in non-Deltaprotoebacterial groups, approximately $78 \%$ of presently confirmed methylators are sulfate-reducing Deltaproteobacteria (Gilmour et al., 2013). Thus, Deltaproteobacteria were chosen as an additional focus for investigating how changes in $\% \mathrm{MeHg}$, which had been altered by experimental sulfate additions, may also be related to changes in the bacterial community structure of the S6 peatland. The Deltaproteobacteria were represented by 546 OTUs, which together comprised $2.5-7.8 \%$ of the weighted abundance per sample (Figure 4.3b). The most common of the eight Deltaproteobacterial orders present was Myxococcales, represented by 305 OTUs. Ten identified families, of which Syntrophobacteraceae and Cystobacteraceae were most abundant, were also found (Supplementary Table 7.1.5).

Unlike the whole bacterial community, Deltaproteobacterial communities did exhibit significant or nearly significant correlations with \%MeHg for both the bog and lagg areas (bog: Mantel $r=$ $0.56, \mathrm{p}=0.008$, lagg: Mantel $r=0.36, \mathrm{p}=0.057)$. This relationship between

Deltaproteobacterial community structure and $\% \mathrm{MeHg}$ suggests that the frequently-observed changes in MeHg production in response to sulfate (Branfireun et al., 1999; Coleman Wasik et al., 2012; Jeremiason et al., 2006; Mitchell et al., 2008) are likely related to changes in a 
subsection of the total bacterial community structure, but the moderate coefficients of variation indicate that this mechanism most likely occurs in addition to sulfate-mediated stimulation of SRB. Macaladay et al. (2000) found a strong relationship between $\mathrm{Hg}$ methylation rates and community structure of 37 SRB taxa identified using polar lipid fatty acid (PLFA) analysis in sediment from a California lake. Results from this current study extend this work through a more comprehensive accounting of the bacterial community and suggest that sulfate deposition is an important driver for mercury methylation, not simply because of augmented bacterial activity, but also due to controls on community structure.

108 OTU's from the lagg and 80 OTU's from the bog were identified that correlated significantly to $\% \mathrm{MeHg}$ levels in the peat (Supplementary Tables 7.1.6-7.1.7). Significant, positive correlations were found for several known methylating taxa. One OTU in Desulfovibrionaceae, a family hosting the best-known Hg-methylating genera (Compeau and Bartha, 1985; Gilmour et al., 2011) correlated significantly $(\mathrm{p}=0.007, r=0.817)$ with $\% \mathrm{MeHg}$, an interesting finding given the extremely low abundance of this family in the bacterial community $(0-0.25 \%)$. In addition, two OTUs in Syntrophobacteraceae, a Deltaproteobacterial family ( $\mathrm{p}=0.001-0.005, r$ $=0.888-0.833)$, and six OTUs in the Veillonellaceae family of the Firmicutes $(\mathrm{p}=0.007-0.001, r$ $=0.883-0.927)$, correlated with \%MeHg. Both of these groups contain taxa (Syntrophus aciditrophicus SB in Syntrophobacterales, and Desulfitobacterium metallireducens, Desulfosporosinus acidiphilus SJ4, Desulfitobacterium dehalogenans, Desulfosporosinus youngiae, Ethanoligenens harbinense YUAN-3, Dethiobacter alkaliphilus AHT 1 in Firmicutes) that have been recently identified in vitro as $\mathrm{Hg}$ methylators (Gilmour et al., 2013). Correlations observed are consistent with the hypothesis that these groups may methylate $\mathrm{Hg}$ in peat. 


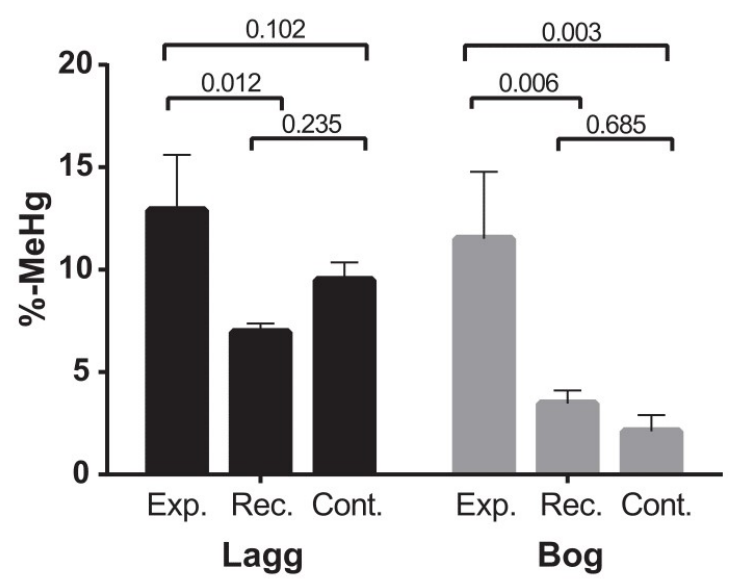

Figure 4.5 Methylmercury Accumulation: The mean percentage of total $\mathrm{Hg}$ as $\mathrm{MeHg}(\% \mathrm{MeHg}) \pm$ standard deviation in peat cores from the three sulfate treatments $($ Exp. $=$ experimental; Rec. $=$ recovery; Cont $=$ control). The probabilities $(\mathrm{p} \leq 0.05)$ associated with each pairwise comparison are indicated above the relevant pair of columns.

\subsubsection{Conclusion}

This work consistently supports the hypothesis that experimental increases and decreases in sulfate deposition lead to significant, but reversible, changes in the taxonomic composition of a peatland bacterial community. Furthermore, sulfate altered the community composition of the Deltaproteobacteria, and the structure of this community was correlated significantly with net $\mathrm{MeHg}$ accumulation. These results suggest a sulfate-mediated alteration of the Deltaproteobacteria community as a mechanism driving $\mathrm{MeHg}$ concentration changes in this peatland. Finally, it is notable that the experimental rate of sulfate deposition in this experiment simulated historical deposition in, and downwind of, industrial areas of eastern Canada and the US prior to aggressive regulation of sulfate emissions. Findings suggest that previous levels of pollution likely altered both the structure and at least one function ( $\mathrm{MeHg}$ production) of peatland bacterial communities, and that legislated emissions controls likely led to a significant lessening of these effects with a lag-time of well under a decade.

\subsubsection{Acknowledgements}

The authors gratefully acknowledge Shu-Yi Shen and the Qiime community for technical genomics advice, Plank Huang who carried out chemical analyses, and helpful advice from 
Daniel Jones. Additional thanks go to Jeff Jeremiason, Ed Swain, Bruce Monson, Jim Almendinger and Brian Branfireun for their participation in the sulfate-addition experiments, and Randy Kolka, Deacon Kyllander, and Carrie Dorrance of the Northern Research Station for administrative and field assistance throughout the course of the project. This publication was based on work funded by a Discovery Grant from the Natural Sciences and Engineering Research Council of Canada to CPJM, and the U.S. EPA-Science To Achieve Results (STAR) Program, Grant R827630, the Great Lakes Commission, Great Lakes Air Deposition Program, and the Minnesota Pollution Control Agency to DRE. These organizations had no role in the design, interpretation, or presentation of this project. The USDA Forest Service's Northern Research Station provided access to the study site as well as substantial in-kind support.

\subsection{References}

Allison, S.D., Martiny, J.B.H., 2008. Resistance, resilience, and redundancy in microbial communities. Proc. Natl. Acad. Sci. 105, 11512-11519. http://dx.10.1073/pnas.0801925105.

Amann, R.I., Ludwig, W., Scheifer, K.H., 1995. Phylogenetic identification and in situ detection of individual microbial cells without cultivation. Microbiol. Mol. Biol. Rev. 59, 143-169.

Andersen, R., Chapman, S.J., Artz, R.R.E., 2013. Microbial communities in natural and disturbed peatlands: a review. Soil Biol. Biochem. 57, 979-994. http://dx.10.1016/j.soilbio.2012.10.003.

Anderson, M.J., 2001. A new method for non-parametric multivariate analysis of variance. Austral. Ecol. 26, 32-46. http://dx.10.1111/j.1442-9993.2001.01070.pp.x.

Bae, H.-S., Dierberg, F.E., Ogram, A., 2014. Syntrophs dominate sequences associated with the mercury methylation-related gene $h g c a$ in the water conservation areas of the Florida Everglades. Appl. Environ. Microbiol. 80, 6517-6526. http://dx.10.1128/AEM.01666-14.

Blodau, C., Mayer, B., Peiffer, S., Moore, T.R., 2007. Support for an anaerobic sulfur cycle in two Canadian peatland soils. J. Geophys. Res. 112, G02004. http://dx.10.1029/2006JG000364.

Branfireun, B., Roulet, N., Kelly, C., Rudd, J., 1999. In situ sulfate stimulation of mercury methylation in a boreal peatland, toward a link between acid rain and methylmercury contamination in remote environments. Global Biogeochem. Cycles 13, 743-750.

Caporaso, J.G., Kuczynski, J., Stombaugh, J., Bittinger, K., Bushman, F.D., Costello, E.K., Fierer, N., Peña, A.G., Goodrich, J.K., Gordon, J.I., Huttley, G.A., Kelley, S.T., Knights, D., Koenig, J.E., Ley, R.E., Lozupone, C.A., McDonald, D., Muegge, B.D., Pirrung, M., Reeder, J., Sevinsky, J.R., Turnbaugh, P.J., Walters, W.A., Widmann, J., Yatsunenko, T., Zaneveld, J., Knight, R., 2010. 
QIIME allows analysis of high-throughput community sequencing data. Nat. Methods 7, 335336. http://dx.10.1038/nmeth.f.303.

Chao, A., 1984. Non-parametric estimation of the number of classes in a population. Scand. J. Stat. 11, 265-270.

Coleman Wasik, J.K., Mitchell, C.P.J., Engstrom, D.R., Swain, E.B., Monson, B.A., Balogh, S.J., Jeremiason, J.D., Branfireun, B.A., Eggert, S.L., Kolka, R.K., Almendinger, J.E., 2012. Methylmercury declines in a boreal peatland when experimental sulfate deposition decreases. Environ. Sci. Technol. 46, 6663-6671. http://dx.10.1021/es300865f.

Coleman Wasik, J.K., Engstrom, D.R., Mitchell, C.P.J., Swain, E.B., Monson, B.A., Balogh, S.J., Jeremiason, J.D., Branfireun, B.A., Kolka, R.K., Almendinger, J.E., 2015. The effects of hydrologic fluctuation and sulfate regeneration on mercury cycling in an experimental peatland: drought increases mercury in peatlands. J. Geophys. Res. Biogeosciences 120, 1697-1715. http://dx.10.1002/2015JG002993.

Compeau, G.C., Bartha, R., 1985. Sulfate-reducing bacteria: principal methylators of mercury in anoxic estuarine sediment. Appl. Environ. Microbiol. 50, 498-502.

Currey, P.M., Johnson, D., Sheppard, L.J., Leith, I.D., Toberman, H., Van Der Wal, R., Dawson, L.A., Artz, R.R.E., 2009. Turnover of labile and recalcitrant soil carbon differ in response to nitrate and ammonium deposition in an ombrotrophic peatland: enzyme response to $\mathrm{N}$ in peatlands. Glob. Change Biol. 16, 2307-2321. http://dx.10.1111/j.1365-2486.2009.02082.x.

Dedysh, S.N., Pankratov, T.A., Belova, S.E., Kulichevskaya, I.S., Liesack, W., 2006. Phylogenetic analysis and in situ identification of bacteria community composition in an acidic sphagnum peat bog. Appl. Environ. Microbiol. 72, 2110-2117. http://dx.10.1128/AEM.72.3.2110-2117.2006.

Drott, A., Lambertsson, L., Björn, E., Skyllberg, U., 2008. Do potential methylation rates reflect accumulated methyl mercury in contaminated sediments? Environ. Sci. Technol. 42, 153-158. http://dx.10.1021/es0715851.

Edgar, R.C., 2010. Search and clustering orders of magnitude faster than BLAST. Bioinformatics 26, 2460-2461. http://dx.10.1093/bioinformatics/btq461.

Fuhrman, J.A., 2009. Microbial community structure and its functional implications. Nature, 459, 193199. http://dx.10.1038/nature08058.

Gauci, V., Chapman, S.J., 2006. Simultaneous inhibition of CH4 efflux and stimulation of sulfate reduction in peat subject to simulated acid rain. Soil Biol. Biochem. 38, 3506-3510. http://dx.10.1016/j.soilbio.2006.05.011.

Gilmour, C.C., Elias, D.A., Kucken, A.M., Brown, S.D., Palumbo, A.V., Schadt, C.W., Wall, J.D., 2011. Sulfate-reducing bacterium Desulfovibrio desulfuricans nd132 as a model for understanding 
bacterial mercury methylation. Appl. Environ. Microbiol. 77, 3938-3951.

http://dx.10.1128/AEM.02993-10

Gilmour, C.C., Henry, E.A., Mitchell, R., 1992. Sulfate stimulation of mercury methylation in freshwater sediments. Environ. Sci. Technol. 26, 2281-2287.

Gilmour, C.C., Podar, M., Bullock, A.L., Graham, A.M., Brown, S.D., Somenahally, A.C., Johs, A., Hurt, R.A., Bailey, K.L., Elias, D.A., 2013. Mercury methylation by novel microorganisms from new environments. Environ. Sci. Technol. 47, 11810-11820. http://dx.10.1021/es403075t.

Griffiths, B.S., Philippot, L., 2012. Insights into the resistance and resilience of the soil microbial community. FEMS Microbiol. Rev. 37, 112-129. http://dx.10.1111/j.1574-6976.2012.00343.x.

Hamady, M., Lozupone, C., Knight, R., 2009. Fast UniFrac: facilitating high-throughput phylogenetic analyses of microbial communities including analysis of pyrosequencing and PhyloChip data. ISME J. 4, 17-27.

Hintelmann, H., Evans, R.D., 1997. Application of stable isotopes in environmental tracer studies measurement of monomethylmercury $\left(\mathrm{CH}_{3} \mathrm{Hg}^{+}\right)$by isotope dilution ICP-MS and detection of species transformation. Fresenius J. Anal. Chem. 358, 378-385.

http://dx.10.1007/s002160050433.

Horvat, M.; Bloom, N.S.; Liang, L., 1993. Comparison of distillation with other current isolation methods for the determination of methyl mercury compounds in low level environmental samples. Part 1. Sediments. Anal. Chim. Acta. 281, 135-152.

Jeremiason, J.D., Engstrom, D.R., Swain, E.B., Nater, E.A., Johnson, B.M., Almendinger, J.E., Monson, B.A., Kolka, R.K., 2006. Sulfate addition increases methylmercury production in an experimental wetland. Environ. Sci. Technol. 40, 3800-3806. http://dx.10.1021/es0524144.

Juottonen, H., Galand, P.E., Tuittila, E.-S., Laine, J., Fritze, H., Yrjala, K., 2005. Methanogen communities and bacteria along an ecohydrological gradient in a northern raised bog complex. Environ. Microbiol. 7, 1547-1557. http://dx.10.1111/j.1462-2920.2005.00838.x.

Kahl, J.S., Stoddard, J.L., Haeuber, R., Paulsen, S.G., Birnbaum, R., Deviney, F.A., Webb, J.R., DeWalle, D.R., Sharpe, W., Driscoll, C.T., Herlihy, A.T., Gellogg, J.H., Murdoch, P.S., Roy, K., Webster, K.E., Urquhart, N.S., 2004. Have US surface waters responded to the 1990 Clean Air Act amendments? Environ. Sci. Technol. 38, 484A-490A.

Keller, J.K., Bridgham, S.D., 2007. Pathways of anaerobic carbon cycling across an ombrotrophicminerotrophic peatland gradient. Limnol. Oceanogr. 52, 96-107.

Kunin, V., Engelbrektson, A., Ochman, H., Hugenholtz, P., 2010. Wrinkles in the rare biosphere: pyrosequencing errors can lead to artificial inflation of diversity estimates. Environ. Microbiol. 12, 118-123. http://dx.10.1111/j.1462-2920.2009.02051.x. 
Limpens, J., Berendse, F., Blodau, C., Canadell, J.G., Freeman, C., Holden, J., Roulet, N., Rydin, H., Schaepman-Strub, G., 2008. Peatlands and the carbon cycle: from local processes to global implications-a synthesis. Biogeosciences 5, 1475-1491.

Lin, X., Green, S., Tfaily, M.M., Prakash, O., Konstantinidis, K.T., Corbett, J.E., Chanton, J.P., Cooper, W.T., Kostka, J.E., 2012. Microbial community structure and activity linked to contrasting biogeochemical gradients in bog and fen environments of the glacial Lake Agassiz Peatland. Appl. Environ. Microbiol. 78, 7023-7031. http://dx.10.1128/AEM.01750-12.

Lovley, D.R., Klug, M.J., 1983. Sulfate reducers can outcompete methanogens at freshwater sulfate concentrations. Appl. Environ. Microbiol. 45, 187-192.

Lozupone, C., Knight, R., 2005. UniFrac: a new phylogenetic method for comparing microbial communities. Appl. Environ. Microbiol. 71, 8228-8235. http://dx.10.1128/AEM.71.12.82288235.2005 .

Luck, G.W., Daily, G.C., Ehrlich, P.R., 2003. Population diversity and ecosystem services. Trends Ecol. Evol. 18, 331-336. http://dx.10.1016/S0169-5347(03)00100-9.

Macalady, J.L., Mack, E.E., Nelson, D.C., Scow, K.M., 2000. Sediment microbial community structure and mercury methylation in mercury-polluted Clear Lake, California. Appl. Environ. Microbiol. 66, 1479-1488. http://dx.10.1128/AEM.66.4.1479-1488.2000.

Mayewski, P.A., Lyons, W.B., Spencer, M.J., Twickler, M.S., Buck, C.F., Withlow, S., 1990. An ice-core record of atmospheric response to anthropogenic sulfate and nitrate. Nature 346, 554-556.

McArdle, B.H., Anderson, M.J., 2001. Fitting multivariate models to community data: a comment on distance-based redundancy analysis. Ecology 82, 290-297. http://dx.10.1890/00129658(2001)082[0290:FMMTCD]2.0.CO;2.

McKew, B.A., Taylor, J.D., McGenity, T.J., Underwood, G.J., 2011. Resistance and resilience of benthic biofilm communities from a temperate saltmarsh to desiccation and rewetting. ISME J. 5, 30-41.

Mitchell, C.P.J., Branfireun, B.A., Kolka, R.K., 2009. Methylmercury dynamics at the upland-peatland interface: topographic and hydrogeochemical controls. Water Resour. Res. 45, http://dx.10.1029/2008WR006832.

Mitchell, C.P.J., Branfireun, B.A., Kolka, R.K., 2008. Spatial characteristics of net methylmercury production hot spots in peatlands. Environ. Sci. Technol. 42, 1010-1016. http://dx.10.1021/es0704986.

Munthe, J., Bodaly, R.A., Branfireun, B.A., Driscoll, C.T., Gilmour, C.C., Harris, R., Horvat, M., Lucotte, M., Malm, O., 2007. Recovery of mercury-contaminated fisheries. AMBIO J. Hum. Environ. 36, 33-44. http://dx.10.1579/0044-7447(2007)36[33:ROMF]2.0.CO;2. 
Muyzer, G., Stams, A.J.M., 2008. The ecology and biotechnology of sulfate-reducing bacteria. Nat. Rev. Microbiol. 6, 441-454. http://dx.10.1038/nrmicro1892.

National Atmospheric Deposition Program/National Trends Network, 2006. Annual \& seasonal data summary for Site MN16. http: //nadp.sws.uiuc.edu/ads/2006/MN16.pdf.

Nelson, T.M., Streten, C., Gibb, K.S., Chariton, A.A., 2015. Saltwater intrusion history shapes the response of bacterial communities upon rehydration. Sci. Total Environ. 502, 143-148. http://dx.10.1016/j.scitotenv.2014.08.109.

Pak, K.-R., Bartha, R., 1998. Mercury methylation by interspecies hydrogen and acetate transfer between sulfidogens and methanogens. Appl. Environ. Microbiol. 64, 1987-1990.

Pankratov, T.A., Belova, S.E., Dedysh, S.N., 2005. Evaluation of the phylogenetic diversity of prokaryotic microorganisms in sphagnum peat bogs by means of fluorescence in situ hybridization (FISH). Microbiology 74, 722-728.

Payne, R., Gauci, V., Charman, D.J., 2009. The impact of simulated sulfate deposition on peatland testate amoebae. Microb. Ecol. 59, 76-83. http://dx.10.1007/s00248-009-9552-6.

Pennanen, T., Fritze, H., Vanhala, P., Kiikkilä, O., Neuvonen, S., Bååth, E., 1998. Structure of a microbial community in soil after prolonged addition of low levels of simulated acid rain. Appl. Environ. Microbiol. 64, 2173-2180.

Pester, M., 2012. Sulfate-reducing microorganisms in wetlands - fameless actors in carbon cycling and climate change. Front. Microbiol. 3. http://dx.10.3389/fmicb.2012.00072.

Price, M.N., Dehal, P.S., Arkin, A.P., 2010. FASTTREE 2 - approximately maximum-likelihood trees for large alignments. PLoS ONE 5, e9490. http://dx.10.1371/journal.pone.0009490.

Ranchou-Peyruse, M., Monperrus, M., Bridou, R., Duran, R., Amouroux, D., Salvado, J.C., Guyoneaud, R., 2009. Overview of mercury methylation capacities among anaerobic bacteria including representatives of the sulfate-reducers: implications for environmental studies. Geomicrobiol. J. 26, 1-8. http://dx.10.1080/01490450802599227.

Scheffer, M., Carpenter, S., Foley, J.A., Folke, C., Walker, B., 2001. Catastrophic shifts in ecosystems. Nature 413, 591-596.

Schmalenberger, A., Drake, H.L., Küsel, K., 2007. High unique diversity of sulfate-reducing prokaryotes characterized in a depth gradient in an acidic fen. Environ. Microbiol. 9, 1317-1328. http://dx.10.1111/j.1462-2920.2007.01251.x.

Seifert-Monson, L.R., Hill, B.H., Kolka, R.K., Jicha, T.M., Lehto, L.L., Elonen, C.M., 2014. Effects of sulfate deposition on pore water dissolved organic carbon, nutrients, and microbial enzyme activities in a northern peatland. Soil Biol. Biochem. 79, 91-99. http://dx.10.1016/j.soilbio.2014.09.007. 
Serkebaeva, Y.M., Kim, Y., Liesack, W., Dedysh, S.N., 2013. Pyrosequencing-based assessment of the bacteria diversity in surface and subsurface peat layers of a northern wetland, with focus on poorly studied phyla and candidate divisions. PLoS ONE 8, e63994. http://dx.10.1371/journal.pone.0063994.

Steger, D., Wentrup, C., Braunegger, C., Deevong, P., Hofer, M., Richter, A., Baranyi, C., Pester, M., Wagner, M., Loy, A., 2011. Microorganisms with novel dissimilatory (bi)sulfite reductase genes are widespread and part of the core microbiota in low-sulfate peatlands. Appl. Environ. Microbiol. 77, 1231-1242. http://dx.10.1128/AEM.01352-10.

Vile, M.A., Bridgham, S.D., Wieder, R.K., Novák, M., 2003. Atmospheric sulfur deposition alters pathways of gaseous carbon production in peatlands: $\mathrm{S}$ deposition alters gaseous c production in peatlands. Glob. Biogeochem. Cycles 17, http://dx.10.1029/2002GB001966.

Yu, R.-Q., Adatto, I., Montesdeoca, M.R., Driscoll, C.T., Hines, M.E., Barkay, T., 2010. Mercury methylation in sphagnum moss mats and its association with sulfate-reducing bacteria in an acidic Adirondack forest lake wetland. FEMS Microbiol. Ecol. 74, 655-668. http://dx.10.1111/j.15746941.2010.00978.x. 


\section{Chapter 5}

\section{Accumulation and translocation of methylmercury and inorganic mercury in Oryza sativa: an enriched isotope tracer study}

This chapter is reproduced as published in Science of the Total Environment (Strickman, R.J., Mitchell, C.P.J., 2016. Accumulation and translocation of methylmercury and inorganic mercury in Oryza sativa: an enriched isotope tracer study. Sci. Total Environ. doi:10.1016/j.scitotenv.2016.08.068). Reproduced with permission from Science of the Total Environment. 


\subsection{Abstract}

Methylmercury ( $\mathrm{MeHg}$ ) accumulation in rice is an emerging human health issue, but uptake pathways and translocation into the grain remain poorly understood. We grew Oryza sativa plants in pots of wetland soil amended with an enriched mercury isotope $\left(94.3 \%{ }^{200} \mathrm{Hg}\right)$ tracer, alongside unvegetated control pots, and assessed both ambient and tracer $\mathrm{MeHg}$ and inorganic $\mathrm{Hg}(\mathrm{IHg})$ concentrations in soil and plant tissues at three growth stages. Based on similar ratios of ambient:tracer $\mathrm{MeHg}$ concentrations in soil and plant tissues, we provide the first direct evidence that $\mathrm{MeHg}$ is first synthesized in saturated soil and subsequently translocated to rice grains. There is no evidence of in planta methylation of IHg, but significant losses of $\mathrm{MeHg}$ from plant tissues between flowering and maturity indicates likely in planta demethylation. In this greenhouse experiment, lower percent of tracer $\mathrm{MeHg}$ in vegetated soils at late growth stages suggests that rice plants reduce the net $\mathrm{MeHg}$ accumulation capacity of soils, although the mechanism remains unclear. For $\mathrm{IHg}$, we find that roots accumulate $\mathrm{Hg}$ from the soil, straw from the soil and the atmosphere, and grain almost entirely from the atmosphere. Management strategies that aim to reduce $\mathrm{MeHg}$ accumulation in rice should focus on mercury methylation in paddy soils, but IHg reductions will depend on regional controls of atmospheric $\mathrm{Hg}$. 


\subsection{Introduction}

Methylmercury $(\mathrm{MeHg})$ is the highly bioaccumulative form of mercury $(\mathrm{Hg})$ and is a contaminant of global concern due to links between low level exposure and neurological impairment (Clarkson and Magos, 2006). Exposure to MeHg is mostly associated with the consumption of aquatic organisms, particularly ocean fish (Li et al., 2014), but ingestion of rice cultivated in Hg-contaminated areas of China (Feng et al., 2008; Li et al., 2012; Rothenberg et al., 2011b; Zhang et al., 2010a), Cambodia (Cheng et al., 2013), and elsewhere (Rothenberg et al., 2014) has been gaining attention as an additional, significant source of dietary MeHg. Since rice is the worlds most widely cultivated crop and the staple food of approximately 3 billion people (Khush, 2005), MeHg exposure via rice consumption is a growing concern worldwide.

Like other wetlands, flooded rice paddies are sites of active Hg methylation (Liu et al., 2014; Rothenberg and Feng, 2012), a process carried out by a wide taxonomic range of anaerobic microorganisms (Gilmour et al., 2013). Correlations between soil and rice grain MeHg concentrations suggest that grain $\mathrm{MeHg}$ originates from $\mathrm{Hg}$ methylated in the soil (Meng et al., 2010; Zhang et al., 2010b); however, it is also possible that inorganic $\mathrm{Hg}$ ( $\mathrm{IHg}$ ) may be methylated in planta (Horvat et al., 2003; Rothenberg et al., 2014). The source(s) of IHg to the rice plant are also uncertain. There is a strong association between $\mathrm{IHg}$ and $\mathrm{MeHg}$ in rice grains (Rothenberg et al., 2014), but several authors have suggested that translocation pathways and sources may differ between IHg and MeHg. IHg in rice plants may be absorbed from soil (Zhang et al., 2010b), the atmosphere (Meng et al. 2011), or a mixture of these sources (Meng et al., 2014, 2012), with the dominant source likely differing among plant tissues (Meng et al., 2010; Yin et al., 2013). Without a robust understanding and greater certainty of where $\mathrm{MeHg}$ and $\mathrm{IHg}$ in rice grain originates, effective engineering or environmental management strategies to mitigate $\mathrm{MeHg}$ contamination of rice grain cannot be successfully implemented.

The current understanding of both $\mathrm{MeHg}$ and IHg accumulation in rice is mostly based on correlative research in which $\mathrm{Hg}$ or $\mathrm{MeHg}$ concentrations in different plant and environmental compartments are related to one another, and translocation pathways are inferred. Enriched stable isotope tracers are a powerful alternative to this correlative approach (Werner et al., 2012) and have been applied to understanding the sources, translocation, and in planta distribution of mercury through forest understory vegetation (Schwesig and Krebs, 2003) and sawgrass (Mao et 
al., 2013), but not rice. In this study, we combined enriched stable isotope tracer techniques with a controlled greenhouse experiment cultivating rice plants to investigate the following questions: 1) Is MeHg translocated from soil to aboveground plant parts (including grain) and, if so, when does this occur? and 2) Does IHg originate from similar sources as $\mathrm{MeHg}$ ?

\subsection{Materials and Methods}

\subsubsection{Experimental Design}

This greenhouse rice cultivation experiment was conducted as a complete, randomized block design incorporating two vegetation treatments (rice/no rice) and three growth stages, with ten replicates for each combination. We dosed all pots of soil with an enriched stable $\mathrm{Hg}$ isotope tracer $\left(94.3 \%\right.$ enriched $\left.{ }^{200} \mathrm{Hg}\right)$ and cultivated rice (Oryza sativa L. ssp. japonica cv. Nipponbare) in flooded pots under greenhouse conditions. At tillering, flowering, and grain maturity growth stages, we sacrificed ten plants/pots and sampled soil, stems and leaves (collectively straw), roots, panicles, and grain, as applicable. Tillering, characterized by the formation of lateral shoots, signalled the initiation of rapid vegetative growth; flowering represented the beginning of reproduction; and grain maturity was assessed by the presence of drooping, filled grains. At the same time as vegetative sampling, we also sampled soil from unvegetated control pots. All samples were simultaneously analysed for natural background (ambient) and excess ${ }^{200} \mathrm{Hg}$ (tracer) concentrations of total $\mathrm{Hg}(\mathrm{THg})$ and $\mathrm{MeHg}$.

\subsubsection{Sediment Dosing, Plant Cultivation and Sample Collection}

Sediment was collected from the top fifty centimeters of a shallow, vegetated littoral area of

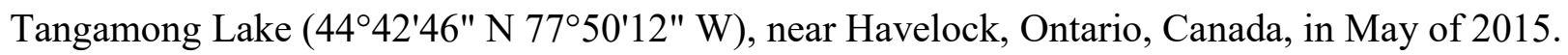
Soil was homogenized by hand and fragments of plant material and detritus were removed, resulting in an organic matter content of $12.8 \%$ and a bulk density of $0.388 \mathrm{~g} \mathrm{~cm}^{-3}$. Sixty liters of soil were amended with an enriched $(94.3 \%){ }^{200} \mathrm{Hg}$ solution $\left(\right.$ as $\mathrm{HgCl}^{+}$) to arrive at a final isotope tracer concentration of approximately $50 \mathrm{ng} \mathrm{g}^{-1}$ dry weight and kept in the dark at $4{ }^{\circ} \mathrm{C}$ for one month to allow the added $\mathrm{Hg}$ tracer to adsorb to and equilibrate with the soil. During this time, soils were fully saturated and stirred daily to prevent the formation of strongly reducing conditions. After one month, $1.5 \mathrm{~L}$ of soil was added to each of forty opaque, watertight three- 
liter plastic pots. The pot filling order was randomized, as was the assignment of pots to blocks $(\mathrm{n}=10)$. Blocks were re-randomized weekly.

Rice seeds (Oryza sativa L. ssp. japonica cv. Nipponbare) were obtained from the Genetic Stocks-Oryza collection of the United States Department of Agriculture in Stuttgart, Arkansas. Seedlings were germinated and pre-cultivated hydroponically to reduce physiological variability between replicates. Seeds were rinsed thoroughly in deionized water and germinated in aerated distilled water, and two seeds each sown in 0.5-liter plastic containers filled with a 50-50\% soilless mixture of perlite and vermiculite. Seedlings were grown for 25 days under ambient laboratory light supplemented with sodium lamps on a $12 \mathrm{~h}-12 \mathrm{~h}$ light-dark cycle in an aerated hydroponic solution with the following nutrient composition: $\mathrm{N}: 165 \mathrm{mg} \mathrm{l}^{-1} \mathrm{mg} \mathrm{l}^{-1}$, P: $50 \mathrm{mg} \mathrm{l}^{-1}$, $\mathrm{K}: 223 \mathrm{mg} \mathrm{l}^{-1}$, Ca: $313 \mathrm{mg} \mathrm{l}^{-1}$, Mg: $120 \mathrm{mg} \mathrm{l}^{-1}$, S: $122 \mathrm{mg} \mathrm{l}^{-1}$, Fe: $7 \mathrm{mg} \mathrm{l}^{-1}, \mathrm{Mn}: 0.2 \mathrm{mg} \mathrm{l}^{-1}, \mathrm{Zn}: 0.4$ $\mathrm{mg} \mathrm{l}^{-1}, \mathrm{Cu}: 0.1 \mathrm{mg} \mathrm{l}^{-1}$, B: $1.3 \mathrm{mg} \mathrm{l}^{-1}$, Mo: $0.06 \mathrm{mg} \mathrm{l}^{-1}$. The nutrient solution was aerated with two bubblers repositioned daily, adjusted to $\mathrm{pH} 7.5$ with $0.5 \mathrm{M} \mathrm{HCl}$ and $\mathrm{NaOH}$ as necessary, and refreshed weekly. On day 15, duplicate seedlings were removed, leaving a single plant per container. When the seedlings had reached approximately $15 \mathrm{~cm}$ in height on Day 23, seedling height was measured and their photosynthetic rate was assessed as a proxy measure of physiological status using a portable photosynthesis system (Licor-6400XT) with the following internal parameters: $385 \mathrm{ppm}$ carbon dioxide concentration, $1200 \mu \mathrm{mol} \mathrm{m}^{-2} \mathrm{~s}^{-1}$ photosynthetic photon flux density, and 40\% relative humidity. Finally, thirty seedlings were selected on the basis of similar height and photosynthetic rate, randomly assigned to treatments, and transplanted to soil filled pots. To maintain flooded conditions, water was added as necessary to a level of 5-6 $\mathrm{cm}$ above the soil surface. Plants were grown in the greenhouse facilities of the University of Toronto at Scarborough. Natural light was supplemented with sodium lamps on a $12 \mathrm{~h}-12 \mathrm{~h}$ daynight cycle with a three-week dark treatment (10h-14h day-night) beginning 77 days after germination to hasten flowering. Temperature was maintained at $25-30^{\circ} \mathrm{C}$. All pots were fertilized every ten days with alternating applications of $239.65 \mathrm{~g} \mathrm{~L}^{-1}$ Peters Unimix water soluble fertilizer (NPK 15-5-15; Solution A), and 239.65 $\mathrm{g} \mathrm{L}^{-1}$ Peters Unimix Plus with $48 \mathrm{~g} \mathrm{~L}^{-1}$ Dissolvine chelated iron supplement (Solution B) until flowering, after which only Solution A was applied (schedule modified from Xu et al., 2009). Unvegetated pots received the same schedule of fertilizers. 
Sampling campaigns and plant harvests were conducted when all plants had reached the appropriate growth stage, which occurred 67 days after germination for tillering, 91 days after germination for flowering, and 113 days after germination for grain maturity. At each growth stage, ten vegetated pots were sacrificed. A small plastic soil corer was used to collect a sample of the entire soil profile, extending from the top of the soil to the bottom of the pot, from both vegetated pots and the unvegetated control pots. Photosynthetic rates were measured in the greenhouse using the same Licor instrument and settings described above. The rice plants were then removed from the pots and transported back to the lab in individually labelled plastic bags, where the entire plant was separated into aboveground and belowground biomass. Soil was carefully removed from belowground biomass (roots) by copious washing with tap water, removal of large debris, and a final rinsing with deionized water. Aboveground biomass was divided into reproductive and nonreproductive fractions as applicable (stems/leaves, collectively straw; panicles; and grain). Grain husks were removed by hand. All plant fractions were weighed after harvest and the dry mass calculated from subsamples that were dried at $104^{\circ} \mathrm{C}$ until stable mass was achieved. Soil and plant tissues for $\mathrm{Hg}$ and $\mathrm{MeHg}$ analysis were freeze-dried and crushed in a glass mortar or shredded with stainless-steel scissors to a fine powder, and stored in airtight plastic containers until analysis. Homogenization tools were thoroughly cleaned between samples to prevent cross-contamination.

\subsubsection{Hg Analyses}

Samples were simultaneously analyzed for both ambient $\mathrm{MeHg}$ (using the dominant ${ }^{202} \mathrm{Hg}$ isotope) and excess $\mathrm{Me}^{200} \mathrm{Hg}$ (tracer; attributed to the added tracer after accounting for ambient isotope ratios) according to Hintelmann and Evans (1997). For MeHg analysis, we applied species-specific isotope dilution techniques wherein samples were distilled in a solution of deionized water, $\mathrm{H}_{2} \mathrm{SO}_{4}, \mathrm{KCl}$, and $\mathrm{CuSO}_{4}$ in acid-cleaned Teflon vessels to which a known mass of enriched $\mathrm{Me}^{199} \mathrm{Hg}$ was added as an internal standard, with analysis by gas chromatography inductively coupled plasma mass spectrometry (ID-GC-ICPMS; Hintelmann et al., 1997). Briefly, $\mathrm{MeHg}$ was liberated from solution via aqueous phase ethylation using sodium tetraethylborate, purged by bubbling with high-purity nitrogen, and concentrated onto a glass trap filled with Tenax ${ }^{\circledR}$. Tenax traps were thermally desorbed on a stream of argon gas, directed through a chromatography column for separation of species and ultimately into an ICP-MS 
(Agilent Technologies 7700x) for Hg isotope detection. For THg analysis, 0.2-0.3 g of sample was digested in $10 \mathrm{~mL}$ of hot nitric acid until vapors became colorless. Digestates were diluted with deionized water to $50 \mathrm{~mL}$ volume, oxidized to $\mathrm{Hg}^{2+}$ by the addition of $0.5 \mathrm{~mL} \mathrm{BrCl}$, and left to react overnight. Digestates were further diluted with deionized water and run on a Tekran 2600 automated $\mathrm{Hg}$ analysis system (automated $\mathrm{SnCl}_{2}$ reduction, dual gold trap amalgamation, and thermal desorption) that was directly hyphenated to an ICP-MS. Inorganic Hg concentrations in each sample were obtained by subtracting MeHg concentrations from $\mathrm{THg}$ concentrations. Ongoing quality control was assessed by the analysis of blanks, duplicate samples, certified sediment reference materials (MESS-3 for THg; ERM CC580 for MeHg) and matrix spikes (THg only). Method detection limits were based on three times the standard deviation of blank results, corrected for the average mass of sample digested. These data are displayed in Table 1.

Table 5.1: Quality control data for MeHg and THg determinations

\begin{tabular}{|c|c|c|c|c|}
\hline & $\begin{array}{l}\text { Method detection limit } \\
\qquad\left(\mathrm{ng} \mathrm{g}^{-1}\right)\end{array}$ & $\begin{array}{c}\text { Certified } \\
\text { Reference } \\
\text { Material } \\
\text { recovery (\%) }\end{array}$ & $\begin{array}{l}\text { Average duplicate } \\
\text { RSD (\%) }\end{array}$ & $\begin{array}{c}\text { Spike } \\
\text { recovery (\%) }\end{array}$ \\
\hline Ambient MeHg & 0.05 & $\begin{array}{r}100 \pm 11 \\
(n=32)\end{array}$ & $\begin{array}{c}5.8 \pm 5.2 \\
\text { ( } n=26 \text { pairs) }\end{array}$ & \\
\hline Excess $\mathrm{Me}^{200} \mathrm{Hg}$ & 0.08 & & $\begin{array}{c}6.3 \pm 13.4 \\
(n=18 \text { pairs })\end{array}$ & \\
\hline Ambient THg & 0.42 & $\begin{array}{l}101 \pm 3 \\
(n=12)\end{array}$ & $\begin{array}{c}4.2 \pm 3.0 \\
(n=14 \text { pairs })\end{array}$ & $\begin{array}{c}95 \pm 11 \\
(n=6)\end{array}$ \\
\hline Excess $\mathrm{T}^{200} \mathrm{Hg}$ & 0.11 & & $\begin{array}{c}7.0 \pm 5.6 \\
(n=10 \text { pairs })\end{array}$ & \\
\hline
\end{tabular}




\subsubsection{Statistical Analyses}

For each variable, normality was assessed separately for soil, roots, straw/panicles, and grain using quantile-quantile plots and frequency histograms. Non-normal variables were successfully transformed. Variables were compared using ANOVA or one- and two-way T-tests at $\alpha \leq 0.05$. All tests were performed using RStudio V 0.99.484. The results of all statistical tests are available in Table 7.2.1.

\subsection{Results and Discussion}

\subsubsection{Inorganic Mercury Tracer Amendment}

Tracer additions closely matched ambient soil IHg concentrations. In preplanting soils, concentrations of both ambient (mean \pm standard deviation $=59.95 \pm 18.91 \mathrm{ng} \mathrm{g}^{-1}$ ) and tracer $\left(48.60 \pm 16.27 \mathrm{ng} \mathrm{g}^{-1}\right) \mathrm{IHg}$ were at the low end of the background soil $\mathrm{Hg}$ levels in the U.S. (Obrist et al., 2011) and even in combination, well below the level of IHg observed to affect soil ecology (Vishnivetskaya et al., 2010). The ratio of ambient:tracer IHg concentrations in vegetated and unvegetated treatments did not vary significantly over the three sampling points $(1.19 \pm 0.15-1.23 \pm 0.13$; Table 7.2.2) from the ambient:tracer IHg ratio in preplanting amended soil (ambient:tracer ratio of $1.24 \pm 0.05$ ) (Figure 1a and Table 7.2.1; $\mathrm{p}>0.05$ ). Thus, sediment homogenization had controlled potential variation in tracer additions between experimental replicates. Tracer Hg reduced in the soils and evaded to the greenhouse atmosphere could not possibly have been a detectable secondary source of $\mathrm{Hg}$ to the plants. Based on the air volume and turnover of the greenhouse, area of the experimental pots, published rates of $\mathrm{Hg}$ evasion from vegetated wetlands (Lindberg et al., 2005; Marsik et al., 2005), and the background range of $\mathrm{Hg}$ in the air of the Northern Hemisphere (Driscoll et al., 2013), we estimate that possible evasion of soil tracer $\mathrm{Hg}$ to the greenhouse atmosphere would have represented considerably less than $1 \%$ of the ambient Hg present in the air (see Supplementary Text 1 in Section 7.2.3 for calculations). We are therefore confident that any tracer $\mathrm{Hg}$ detected as present in plant tissues can only possibly be from a source in the soil. 

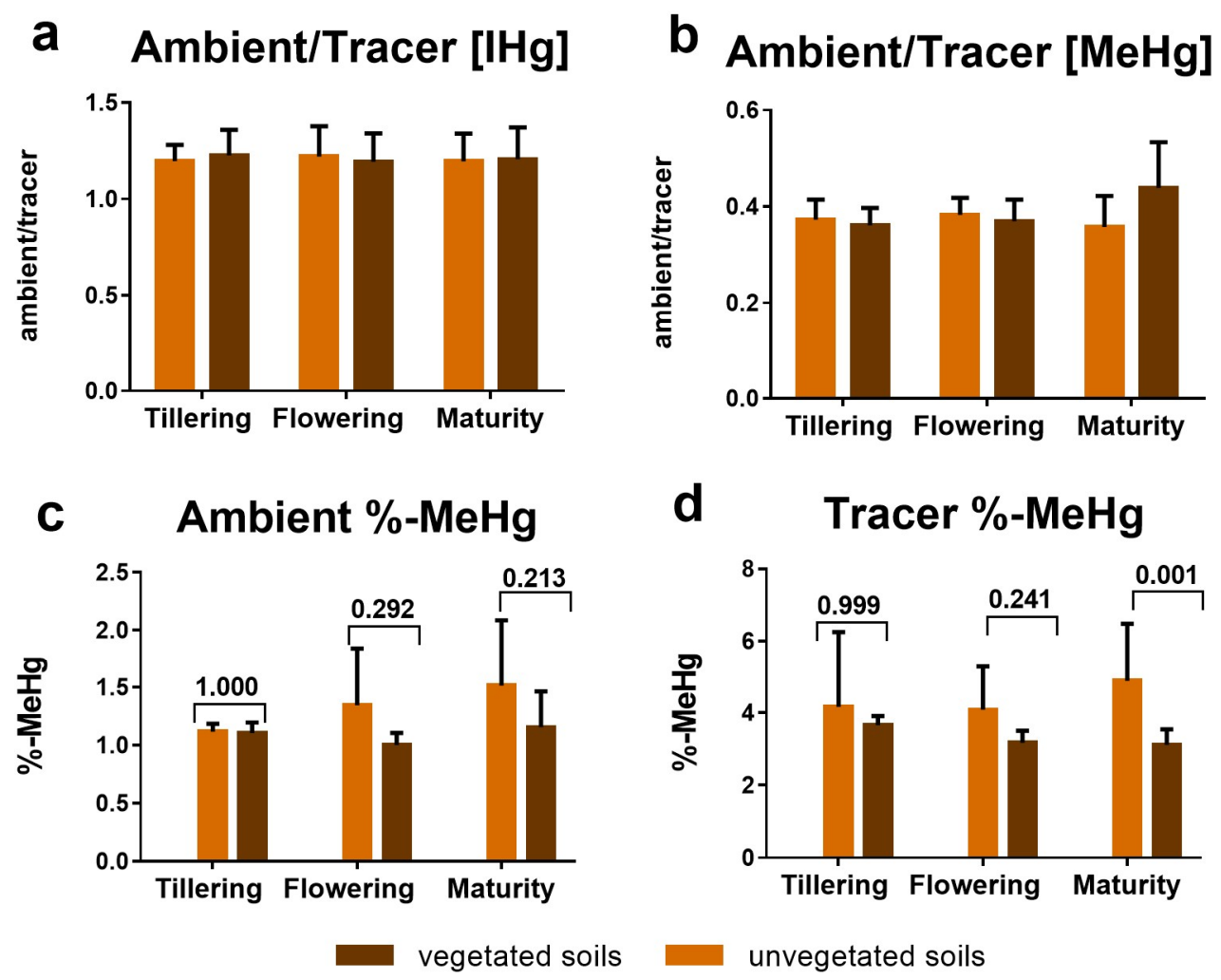

Figure 5.1: Mercury in vegetated and unvegetated soils. Top: ratios of ambient to tracer concentrations for $\mathrm{IHg}$ (a) and $\mathrm{MeHg}$ (b). Bottom: Percent of mercury present as $\mathrm{MeHg}(\% \mathrm{MeHg})$ for ambient (c) and tracer (d). Results of ANOVA post-hoc tests appear above the relevant pair of columns. All bars display mean \pm standard deviation.

\subsubsection{Mercury Methylation in Vegetated and Unvegetated Soils}

Ambient $\mathrm{MeHg}$ concentrations in the soil were relatively low throughout the experiment in both unvegetated (overall mean across all growth stages: $\left.0.59 \pm 0.07 \mathrm{ng} \mathrm{g}^{-1}\right)$ and vegetated $(0.52 \pm$ $0.09 \mathrm{ng} \mathrm{g}^{-1}$ ) soils. Tracer MeHg concentrations were consistently and significantly higher than ambient $\mathrm{MeHg}$ concentrations in unvegetated $\left(1.61 \pm 0.26 \mathrm{ng} \mathrm{g}^{-1}\right)$ and vegetated $(1.21 \pm 0.49 \mathrm{ng}$ $\mathrm{g}^{-1}$ ) soils at all time points (Supplementary Tables 7.2.1-2). Based on the ambient and tracer IHg levels present in preplanting soils, a ratio of 1.24 ambient:tracer $\mathrm{MeHg}$ concentrations would be expected if the tracer were methylated at a similar rate to the $\mathrm{Hg}$ already present in the soil. In contrast, ambient:tracer $\mathrm{MeHg}$ ratios in sediments from tillering, flowering, and maturity growth stages ranged from $0.36 \pm 0.04-0.44 \pm 0.09$ (Figure $1 \mathrm{~b}$ ), representing a $\sim 2.6$ times greater 
bioavailability of the tracer for methylation, a finding in concurrence with previous $\mathrm{Hg}$ amendment experiments (Harris et al., 2007; Mao et al., 2013; Peng et al., 2012; Schwesig and Krebs, 2003). One possible explanation for this increased mercury methylation may be the greater bioavailability of the newly deposited $\mathrm{Hg}$, which some authors have suggested is mostly bound in nanoparticulate (less than $0.45 \mu \mathrm{m}$ ) $\mathrm{Hg}$ sulphide (HgS) particles (Zhang et al., 2012). As Hg ages, nanoparticles may coalesce into large colloids or crystalline $\mathrm{HgS}$ compounds, rendering it less available for uptake by $\mathrm{Hg}$ methylating microorganisms (Graham et al., 2012). While further research is required into why newly deposited $\mathrm{Hg}$ is more microbially bioavailable and for how long this effect endures, this difference should not impact MeHg uptake mechanisms or our interpretation of sources.

The major intent of our study was to assess pathways of MeHg uptake in rice; however, the dosing of soil with enriched $\mathrm{Hg}$ isotope and inclusion of unvegetated control pots also allowed for a unique controlled experiment to assess whether wetland plants such as rice have a positive or negative effect on mercury methylation in rhizosphere soil. Field-based studies have repeatedly observed positive relationships between $\mathrm{MeHg}$ accumulation and the presence and activity of plants in both natural (Canário et al., 2007) and agricultural (Windham-Myers et al., 2009) wetlands, strongly suggesting that MeHg accumulation in vegetated pots should have been higher than in unvegetated pots. However, our controlled greenhouse study did not support the hypothesis that plants and/or their rhizosphere enhance $\mathrm{Hg}$ methylation. When we examined the percentage of $\mathrm{Hg}$ present as $\mathrm{MeHg}(\% \mathrm{MeHg})$, a proxy of net $\mathrm{MeHg}$ production that integrates demethylation and reflects long-term net $\mathrm{MeHg}$ accumulation capacity of a soil (Drott et al., 2008), we observed that $\% \mathrm{MeHg}$ was consistently lower in vegetated than unvegetated pots (Figure 1c,d). Furthermore, tracer \% MeHg in vegetated soils fell somewhat over the course of the experiment, while \% $\mathrm{MeHg}$ in unvegetated soils rose. At the maturity stage, vegetated soils had significantly lower (approximately 35\%) tracer \%MeHg than unvegetated soils. Similar, although not significant disparities developed between the ambient \% MeHg levels of vegetated and unvegetated soils at the flowering and maturity stages (Figure 1c,d, Supplementary Tables 7.2.1-2). These differences between $\mathrm{MeHg}$ accumulation in vegetated and unvegetated soils were related to the presence of rice plants rather than loss due to uptake of $\mathrm{MeHg}$ to rice tissues, which accounted for only 2-5\% of the MeHg mass in the soil of each pot (see Supplementary Text 1 in Section 7.2.4 and Table 7.2.3 for calculations). Given this, our findings can only be 
mechanistically attributed to a rhizosphere-related enhancement of $\mathrm{MeHg}$ demethylation or a slowing of methylation rates that allows background demethylation to degrade the accumulated MeHg. Mercury demethylation ability is widely distributed throughout the prokaryotes (Lin et al., 2012), and occurs in a wide range of biogeochemical conditions, almost certainly including these experimental pots.

We speculate that plants decrease $\mathrm{Hg}$ methylation by reducing the bioavailable fraction of $\mathrm{IHg}$, perhaps through sorption to or co-precipitation with the iron plaque formed on the outside of roots (Meng et al., 2010; Wang et al., 2014) or on root biomass itself (Ullrich et al., 2001). This explanation is supported by the greater effect of vegetation on tracer $\% \mathrm{MeHg}$ compared to ambient \% MeHg. As described above, a larger proportion of the ambient IHg was evidently already bound in more recalcitrant, less bioavailable forms, and thus additional decreases in ambient IHg bioavailability would be less apparent in vegetated soils. Alternatively, rice plants may have increased demethylation at later growth stages, perhaps through stimulation of mercury demethylating microorganisms from labile carbon in root exudates.

It should be emphasized that there are many important differences between laboratory microcosms and the field environment, particularly the lack of subsurface porewater transport and its associated solutes, a process that is an important modulator of $\mathrm{MeHg}$ dynamics in rice fields (Bachand et al., 2014; Windham-Myers et al., 2014, 2013). These authors observed a rhizoconcentration effect as evapotranspiration drove the movement of porewater $\mathrm{MeHg}$ from the bulk to the rhizosphere soil. This process could not occur in our experimental pots, which were entirely colonized with plant roots at the flowering and grain production stages. We hypothesize that the apparent inhibitory effect of plants on soil $\mathrm{MeHg}$ accumulation observed in this laboratory experiment, may also occur in the field, but be masked by the rhizoconcentration effect. This suggests that in circumstances where the movement of porewater is very low, plants may decrease, rather than increase $\mathrm{MeHg}$ accumulation. 


\subsubsection{Uptake, Translocation, and Bioaccumulation of $\mathrm{MeHg}$ and $\mathrm{IHg}$ in Plant Tissues}

\subsubsection{Methylmercury}

The prevailing hypothesis regarding the origin of $\mathrm{MeHg}$ in rice grain is that $\mathrm{MeHg}$ produced in soil is taken up by roots and translocated to aboveground biomass. This paradigm is supported by correlative evidence linking $\mathrm{MeHg}$ concentrations in paddy soils to $\mathrm{MeHg}$ concentrations in rice tissues and grain (Meng et al., 2011, 2010; Rothenberg et al., 2011a). The main purpose of the study presented here was to experimentally determine the likelihood of soil as the sole $\mathrm{MeHg}$ source to grain using an enriched stable $\mathrm{Hg}$ tracer. Alternative sources that would not be detectable in previous work could possibly include adsorption of aqueous or periphyton $\mathrm{MeHg}$ through submerged stems or in planta methylation of inorganic $\mathrm{Hg}$ derived from either soil or the atmosphere (Cosio et al., 2014). In our study, with a unique signal for MeHg derived from soil methylation, a dilution of that signal in plant parts would signify that other sources are important to the accumulation of $\mathrm{MeHg}$ in rice.

Our experiment strongly supports the hypothesis that $\mathrm{MeHg}$ in rice is solely derived from $\mathrm{MeHg}$ produced in the soil where the plant is cultivated. Ambient:tracer ratios for $\mathrm{MeHg}$ in aboveground biomass $(0.23 \pm 0.07-0.34 \pm 0.05)$, including rice grain $(0.34 \pm 0.05)$ were close to, but $27 \%$ less than ratios observed in soil $(0.36 \pm 0.04-0.44 \pm 0.0$ across the three growth stages; Figure 2a,b, Table 7.2.2). These differences were statistically significant (Table 7.2.1). This smaller aboveground biomass ratio could theoretically be related to a bias toward greater demethylation of ambient $\mathrm{MeHg}$ in planta, in planta methylation of tracer $\mathrm{IHg}$, or to preferential translocation of tracer $\mathrm{MeHg}$ from soil into aboveground biomass. Previous research has observed that ambient and tracer $\mathrm{MeHg}$ are demethylated at equivalent rates (Hintelmann et al., 2000), and that in-planta methylation of $\mathrm{IHg}$ in rice is unlikely (Xu et al., 2016). Given these findings, and our consistent observations of greater tracer $\mathrm{MeHg}$ compared to ambient $\mathrm{MeHg}$ concentrations in plant materials (Figure 3), our work strongly supports the preferential translocation of newly added tracer MeHg. Moreover, the soil:root bioaccumulation factors, calculated as concentration in roots over concentration in soil, were approximately $28 \%$ greater for tracer $\mathrm{MeHg}$ than for ambient $\mathrm{MeHg}$ (Figure 2c,d), which matched nearly exactly to the proportionate differences observed in soil versus plant part ambient:tracer $\mathrm{MeHg}$ concentration 
ratios. Similar patterns of increased $\mathrm{MeHg}$ bioaccumulation that had been formed from newly added IHg have been previously observed (Mao et al., 2013). MeHg in soils is bound in several pools of varying bioavailability to rice plants (Zhu et al., 2015), and newly formed MeHg may indeed be more available for phytouptake. Overall, as others have hypothesized, it is likely that soil $\mathrm{MeHg}$ formed in the soil partitions to pore water and enters the roots (Schwesig and Krebs, 2003), travels to the straw via the phloem/symplastic network (Rothenberg et al., 2015), and then accumulates in the developing grain, possibly as a MeHg-cysteine complex (Meng et al., 2014). 

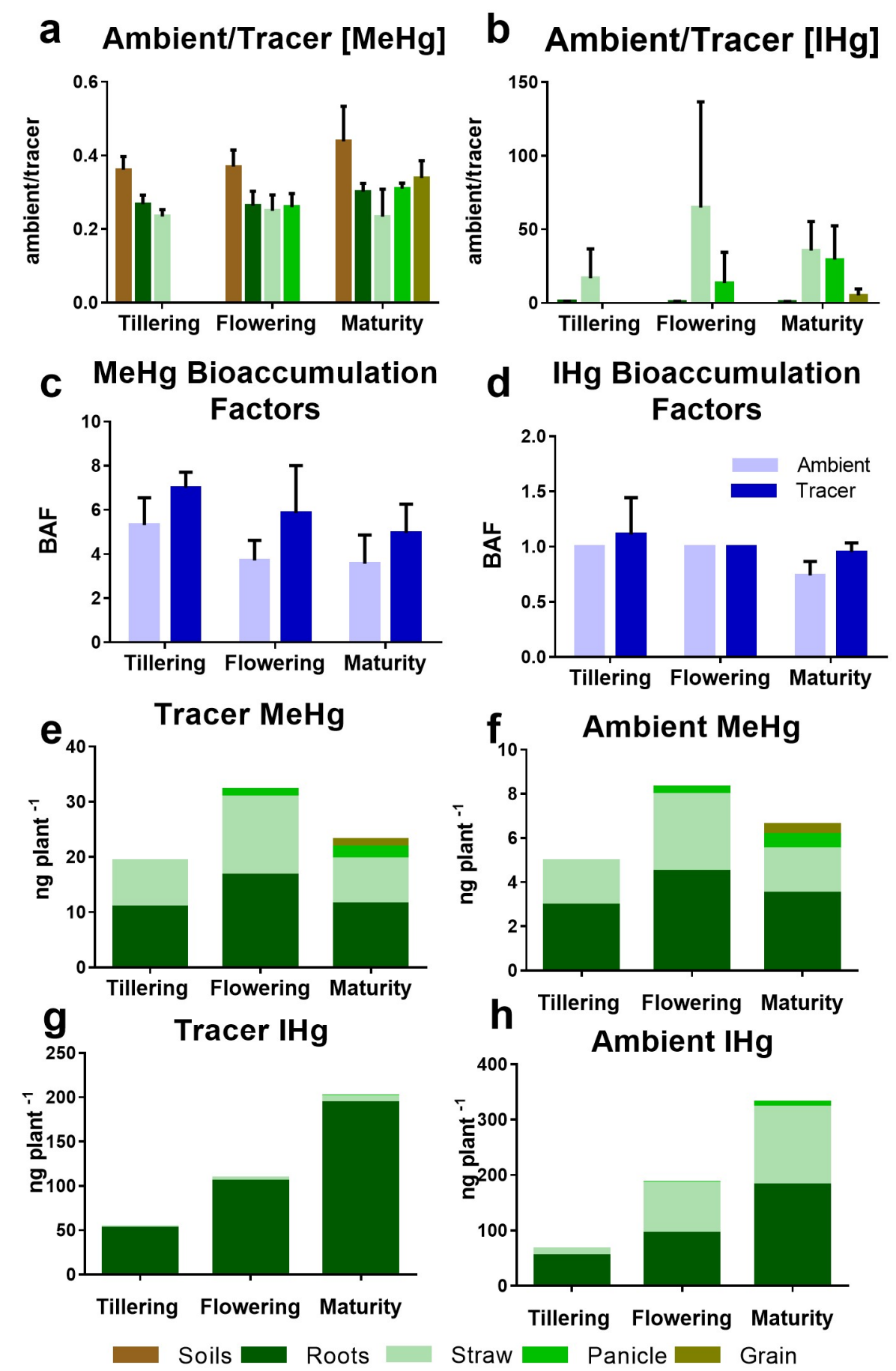

Figure 5.2: Accumulation and distribution of ambient and tracer $\mathrm{MeHg}$ and $\mathrm{IHg}$ in plant tissues at three growth stages. Top: Ambient:tracer ratios (unitless) for $\mathrm{MeHg}$ (a) and $\mathrm{IHg}$ (b). Middle: Root-soil bioaccumulation factors (unitless) for $\mathrm{MeHg}$ (c) and $\mathrm{IHg}(\mathrm{d})$. Bottom: Masses of tracer and ambient $\mathrm{MeHg}(\mathrm{e}, \mathrm{f})$ and $\mathrm{IHg}(\mathrm{g}, \mathrm{h})$ per plant $\left(\mathrm{ng}_{\mathrm{plant}}{ }^{-1}\right)$. All bars display mean \pm standard deviation. 
Temporal patterns of $\mathrm{MeHg}$ distribution in plant tissues suggest that the greatest uptake of $\mathrm{MeHg}$ occurs before flowering, and that growth dilution and in planta demethylation may reduce $\mathrm{MeHg}$ burdens later in the plant's life. Ambient and tracer MeHg concentrations in roots and straw were highest during tillering, and decreased in subsequent growth stages (Figure 3, Table 7.2.2), suggesting that a large initial uptake was diluted by ongoing growth. However, when $\mathrm{MeHg}$ concentrations were multiplied by plant biomass to yield the total mass of $\mathrm{MeHg}$ in each plant compartment, a different pattern emerged. Ambient and tracer $\mathrm{MeHg}$ masses were highest at the flowering stage, increasing significantly (Table 7.2 .1 ) by approximately $66 \%$, from tillering to flowering (Figure 2e,f, Table 7.2.3). These results, which are consistent with previous observations in rice (Meng et al., 2011), indicate that the majority of MeHg uptake occurred prior to the initiation of reproduction (flowering) when vegetative growth was proceeding most quickly. This pattern suggests that investigations into the mechanism of $\mathrm{MeHg}$ uptake should focus on nutrient and mineral uptake pathways that are also upregulated at early growth stages, as these may also be involved in MeHg transport. After flowering, we observed that ambient and tracer MeHg masses in roots, straw, and panicles decreased, representing a loss of about $25-30 \%$ of the plant's total MeHg burden (Figure 2e,f, Table 7.2.2), even after translocation to grain had been accounted for. The only plausible explanation for this net loss is in planta demethylation of $\mathrm{MeHg}$ during grain development, possibly with further $\mathrm{Hg}$ (II) reduction to $\mathrm{Hg}(0)$ (Battke et al., 2005) and loss from the plant in the transpirational stream (Lindberg et al., 2005). In planta demethylation has been observed in living rice plants ( $\mathrm{Li}$ et al., 2016; Xu et al., 2016), and may be carried out by endophytic demethylating microorganisms or via abiotic, photolytic demethylation (Lin et al., 2012). We speculate that photolytic demethylation, which is effected by UV light, is responsible for in planta demethylation, based on the greater losses of $\mathrm{MeHg}$ from illuminated straw (approximately 45\% lost between flowering and maturity) compared to belowground roots (approximately 22\% lost; Table 7.2.3). 

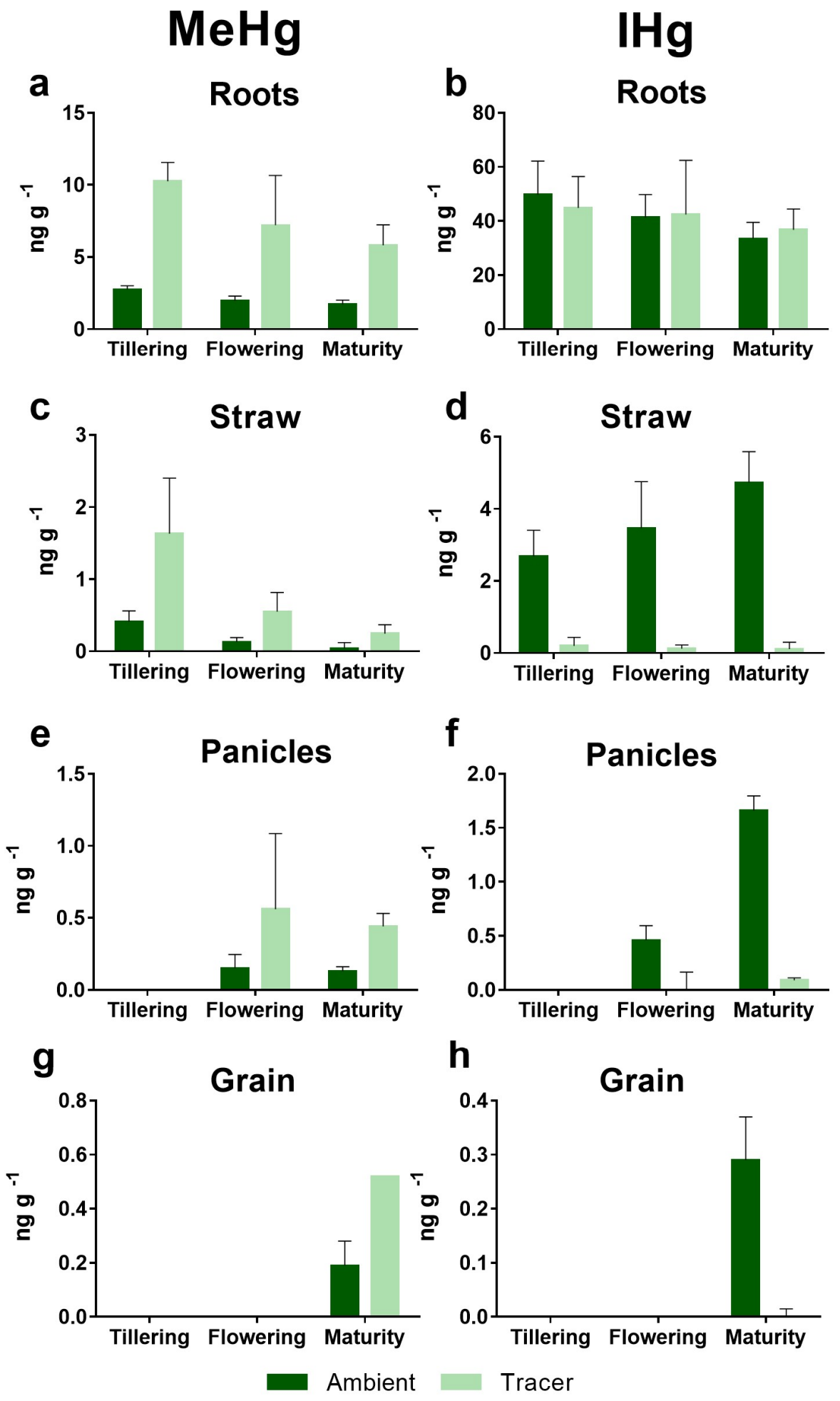

Figure 5.3: Ambient and tracer $\mathrm{MeHg}$ (left) and IHg (right) concentrations in different plant compartments over three growth stages. All bars display mean \pm standard deviation. 
Our stable isotope tracer approach was successfully applied to the question of $\mathrm{Hg}$ source; however the final $\mathrm{MeHg}$ concentration in rice grain was lower than expected. $\mathrm{MeHg}$ concentrations in grain (ambient: $0.21 \pm 0.07 \mathrm{ng} \mathrm{g}^{-1}$, tracer: $0.63 \pm 0.21 \mathrm{ng} \mathrm{g}^{-1}$ ) were below the grain concentrations $\left(1.2-9.4 \mathrm{ng} \mathrm{g}^{-1}\right)$ found by the limited research conducted on rice growing in soils burdened with similar MeHg concentrations (0.5-2 $\mathrm{ng} \mathrm{g}^{-1}$ ) (Li et al., 2013; Meng et al., 2010; Zhou et al., 2015). When MeHg concentrations in rice grain were normalized to $\mathrm{THg}$ concentrations, we found that ambient $\% \mathrm{MeHg}$ values concurred well with other studies (Rothenberg et al. 2014), supporting the ability of our experiment to assess $\mathrm{MeHg}$ and $\mathrm{IHg}$ sources despite unusually low $\mathrm{MeHg}$ concentrations. The cultivar used in this experiment, Nipponbare (also known as Ribenquing in China) accumulates lower concentrations of $\mathrm{MeHg}$ than many other varieties (Li et al., 2013). Rothenberg et al. (2012) have further hypothesized that growing conditions, particularly decreased micronutrient availability, may limit $\mathrm{MeHg}$ uptake to rice grains. Although plants were actively photosynthesizing and adding biomass throughout the experiment (Table 7.2.4), growth conditions experienced by our experimental plants were less than optimal, as evidenced by the relatively low grain yields (7\% of straw biomass), as well as the final plant biomass $(41.57 \pm 8.73)$. These findings support the hypothesis of Rothenberg et al. (2012) that translocation of $\mathrm{MeHg}$ to rice grains is partially mediated by growing conditions and/or plant productivity, rather than a simple function of soil $\mathrm{MeHg}$ content.

\subsubsection{Inorganic Mercury}

Inorganic $\mathrm{Hg}$ in straw and panicles originates partly from the soil and partly from the atmosphere. Tracer IHg was present in the straw and panicles at low but detectable levels (overall mean of 0.27 and $0.11 \mathrm{ng} \mathrm{g}^{-1}$, respectively; Figure $3 \mathrm{c}, \mathrm{d}$ and Table 7.2.2) indicating that translocation of IHg from soil to aboveground tissue does occur. However, foliar uptake was a much more significant source of $\mathrm{IHg}$ to rice photosynthetic tissues, contributing $43-100 \%$ of the ambient IHg in rice straw (calculated after Mao et al. 2013). Marked and significant disparities were observed between ambient:tracer $\mathrm{IHg}$ ratios in straw (overall mean of 39.65) compared to ratios in vegetated soil (6.05) and roots (0.995) (Figure 2b, Supplementary Tables 7.2.1-2). Foliar uptake of IHg has been previously observed in sawgrass (Mao et al., 2013), and hypothesized in rice (Meng et al., 2010), but this is the first time foliar uptake of IHg has been definitively confirmed in rice. Foliar uptake of $\mathrm{Hg}$ from the greenhouse air resulted in an 
additional burden of approximately $130 \mathrm{ng} \mathrm{Hg}$ per plant (Figure $2 \mathrm{~h}$ ) over the duration of our experiment. High local atmospheric mercury levels can result from industries such as artisanal gold mining or coal combustion, as well as from emissions from highly contaminated soils (Cordy et al. 2011; Eckley et al., 2011; Feng et al. 2002), and may be a significant source of IHg to rice straw in areas where mercury-emitting industries and rice cultivation are in proximity to one another (Meng et al. 2011, Limbong et al. 2003).

Rice roots absorb, but do not bioaccumulate IHg from the soil. The presence of tracer IHg in root biomass confirms the soil origin of this Hg fraction (Figure 2) (Meng et al., 2012, 2011), but both ambient and tracer IHg concentrations in roots appeared to be in a simple equilibrium with soil concentrations (Table 7.2.2), with IHg masses increasing over time solely as a result of increasing biomass (Figure $2 \mathrm{~h}$ ). Supporting this interpretation, bioaccumulation factors for $\mathrm{IHg}$ between soil and roots were consistently close to one (Figure 2d). This contrasts markedly with the observed bioaccumulation of $\mathrm{MeHg}$ in roots, supporting the interpretation of other authors that $\mathrm{MeHg}$ and $\mathrm{IHg}$ are transported from the soil to plant tissue via separate pathways (Rothenberg et al., 2014).

Grain IHg appeared to almost entirely originate from the atmosphere. Ambient IHg was detected in all rice samples $\left(0.30 \pm 0.08 \mathrm{ng} \mathrm{g}^{-1}\right)$, but tracer IHg was found at levels above detections limits in only two of ten replicates (mean $0.11 \mathrm{ng} \mathrm{g}^{-1}$ ). Ambient:tracer IHg values for grain (1.17 \pm 2.78) were similar to levels in vegetated soils at the maturity stage $(0.94 \pm 0.09)$, but this comparison was necessarily made using the only nonzero values. More convincing is the almost total absence of tracer IHg in rice grain, supporting the interpretation of Meng et al. (2014) that $\mathrm{IHg}$ is not translocated from roots, but rather incorporated directly from the atmosphere to rice grains, probably sorbing to protein thiol groups, a moiety with a strong affinity for both $\mathrm{MeHg}$ and IHg (Harris et al., 2003). However, it should be noted that translocation of IHg from the soil has been observed in areas with much higher soil IHg concentrations (Feng et al. 2016; Yin et al. 2013), suggesting the sources of IHg to rice grain may vary according to different levels of environmental contamination. 


\subsubsection{Management Implications}

Our project applied enriched stable isotopes to trace the transformation and movement of $\mathrm{IHg}$ and $\mathrm{MeHg}$ in a rice-soil system, allowing us to distinguish between soil and atmospheric mercury contamination and to make suggestions for the practical management of $\mathrm{MeHg}$ and $\mathrm{IHg}$ accumulation in rice. In plant tissues, comparisons of the ratios of newly added tracer to background ambient $\mathrm{MeHg}$ strongly indicate that the $\mathrm{MeHg}$ in rice tissues, including grain, originates in the soil. Additional studies using multiple enriched stable isotopes in other plant and environmental compartments would help to conclusively exclude the possibility of in planta methylation of inorganic tracer $\mathrm{Hg}$, or the uptake of $\mathrm{MeHg}$ from the water via submerged stems (Cosio et al., 2014), but our findings indicate that these are most likely very minor if they occur at all. While our findings should be corroborated by similar experiments in working paddy rice fields, our observations do suggest several avenues for the practical management of $\mathrm{MeHg}$ and IHg accumulation in rice. In examining patterns of uptake of $\mathrm{MeHg}$ over the course of a plant's life, we found that the majority of $\mathrm{MeHg}$ is absorbed before flowering, suggesting that mitigation measures such as paddy water drawdown (Peng et al., 2012), should be timed for this interval. Losses of the total mass of $\mathrm{MeHg}$ from individual plants between the flowering and maturity stages further indicate probable in planta demethylation in rice, the timing of which should be further assessed as a potential strategy for phytoremediation of soil or limitation of $\mathrm{MeHg}$ uptake to grain.

In contrast to $\mathrm{MeHg}$, the $\mathrm{IHg}$ in rice tissues originates from at least two sources, presenting different management challenges. Root burdens of IHg derive solely from soil uptake, while the $\mathrm{IHg}$ in rice straw is absorbed partially from the atmosphere, and grain IHg burdens are absorbed almost completely from the ambient air. The common practice of reincorporating rice straw to fields may inadvertently increase $\mathrm{Hg}$ contamination of agricultural lands by transferring atmospheric $\mathrm{Hg}$ to the soil. This is a particular concern in areas with high atmospheric $\mathrm{Hg}$ concentrations and thus large potential for foliar uptake of IHg. This new IHg input may stimulate mercury methylation, and thus explain observed increases in the production and uptake of $\mathrm{MeHg}$ in fields amended with rice straw (Liu et al., 2016). In grain, the direct absorption of $\mathrm{IHg}$ from the atmosphere rather than uptake from soil means that $\mathrm{IHg}$ concentrations in rice are likely to be little affected by any regulatory measure short of regional reductions in atmospheric 
Hg. This is an important food safety consideration since, unlike other foods (Munthe et al., 2007), IHg makes up 60-70\% of the total $\mathrm{Hg}$ in rice grains according to a recent review by Rothenberg et al. (2014).

\subsection{Acknowledgements}

The authors would like to thank Dr. Jun Jia, Dr. Jack Okamura, and Sandra Harrington for advice on maintaining Nipponbare rice in a northern greenhouse; Professor Roberta Fulthorpe, from whose property soil was collected; Professor Marney Isaac and Professor Sean Thomas for the loan of Licor instruments, and Jessie Wong for assistance with Licor data collection. We are also grateful to Trevor Wilkinson for hydroponic supplies and advice; Aziz Rahman and Sheila Rush of the University of Toronto greenhouse staff; and Shreya Mistry, Kevin Ng, Brent Perron, Demin $\mathrm{Xu}$, and Sampreeth Rao for field and laboratory assistance. We would especially like to acknowledge the tireless analytical excellence of Haiyong (Planck) Huang for assistance in $\mathrm{MeHg}$ and $\mathrm{THg}$ data collection. This work was funded by a Discovery Grant from the Government of Canada to CPJM.

\subsection{References}

Bachand, P.A.M., Bachand, S.M., Fleck, J.A., Alpers, C.N., Stephenson, M., Windham-Myers, L., 2014. Methylmercury production in and export from agricultural wetlands in California, USA: The need to account for physical transport processes into and out of the root zone. Sci. Total Environ. 472, 957-970. doi:10.1016/j.scitotenv.2013.11.086

Battke, F., Ernst, D., Halbach, S., 2005. Ascorbate promotes emission of mercury vapor from plants. Plant Cell Environ. 28, 1487-1495.

Canário, J., Caetano, M., Vale, C., Cesário, R., 2007. Evidence for elevated production of methylmercury in salt marshes. Environ. Sci. Technol. 41, 7376-7382. doi:10.1021/es071078j

Cheng, Z., Wang, H.-S., Du, J., Sthiannopkao, S., Xing, G.-H., Kim, K.-W., Yasin, M.S.M., Hashim, J.H., Wong, M.-H., 2013. Dietary exposure and risk assessment of mercury via total diet study in Cambodia. Chemosphere 92, 143-149. doi:10.1016/j.chemosphere.2013.02.025

Clarkson, T.W., Magos, L., 2006. The toxicology of mercury and its chemical compounds. Crit. Rev. Toxicol. 36, 609-662. doi:10.1080/10408440600845619 
Cosio, C., Flück, R., Regier, N., Slaveykova, V.I., 2014. Effects of macrophytes on the fate of mercury in aquatic systems: Hg and macrophytes. Environ. Toxicol. Chem. 33, 1225-1237.

doi:10.1002/etc.2499

Driscoll, C.T., Mason, R.P., Chan, H.M., Jacob, D.J., Pirrone, N., 2013. Mercury as a global pollutant: Sources, pathways, and effects. Environ. Sci. Technol. 47, 4967-4983. doi:10.1021/es305071v

Drott, A., Lambertsson, L., Björn, E., Skyllberg, U., 2008. Do potential methylation rates reflect accumulated methyl mercury in contaminated sediments? Environ. Sci. Technol. 42, 153-158. doi:10.1021/es0715851

Eckley, C.S., Gustin, M., Marsik, F., Miller, M.B., 2011. Measurement of surface mercury fluxes at active industrial gold mines in Nevada (USA). Sci. Total Environ. 409, 514-522. doi:10.1016/j.scitotenv.2010.10.024

Feng, X., Li, P., Qiu, G., Wang, S., Li, G., Shang, L., Meng, B., Jiang, H., Bai, W., Li, Z., Fu, X., 2008. Human exposure to methylmercury through rice intake in mercury mining areas, Guizhou Province, China. Environ. Sci. Technol. 42, 326-332. doi:10.1021/es071948x

Gilmour, C.C., Podar, M., Bullock, A.L., Graham, A.M., Brown, S.D., Somenahally, A.C., Johs, A., Hurt, R.A., Bailey, K.L., Elias, D.A., 2013. Mercury methylation by novel microorganisms from new environments. Environ. Sci. Technol. 47, 11810-11820. doi:10.1021/es403075t

Graham, A.M., Aiken, G.R., Gilmour, C.C., 2012. Dissolved organic matter enhances microbial mercury methylation under sulfidic conditions. Environ. Sci. Technol. 46, 2715-2723. doi:10.1021/es203658f

Harris, H.H., Pickering, I.J., George, G.N., 2003. The chemical form of mercury in fish. Science 301, 1203-1203.

Harris, R.C., Rudd, J.W.M., Amyot, M., Babiarz, C.L., Beaty, K.G., Blanchfield, P.J., Bodaly, R.A., Branfireun, B.A., Gilmour, C.C., Graydon, J.A., Heyes, A., Hintelmann, H., Hurley, J.P., Kelly, C.A., Krabbenhoft, D.P., Lindberg, S.E., Mason, R.P., Paterson, M.J., Podemski, C.L., Robinson, A., Sandilands, K.A., Southworth, G.R., St. Louis, V.L., Tate, M.T., 2007. Whole-ecosystem study shows rapid fish-mercury response to changes in mercury deposition. Proc. Natl. Acad. Sci. 104, 16586-16591. doi:10.1073/pnas.0704186104

Hintelmann, H., Evans, R.D., 1997. Application of stable isotopes in environmental tracer studies Measurement of monomethylmercury $(\mathrm{CH} 3 \mathrm{Hg}+)$ by isotope dilution ICP-MS and detection of species transformation. Fresenius J. Anal. Chem. 358, 378-385.

Hintelmann, H., Falter, R., Ilgen, G., Evans, R.D., 1997. Determination of artifactual formation of monomethylmercury $\left(\mathrm{CH}_{3} \mathrm{Hg}^{+}\right)$in environmental samples using stable $\mathrm{Hg}^{2+}$ isotopes with ICP- 
MS detection: calculation of contents applying species specific isotope addition. Fresenius J. Anal. Chem. 358, 363-370.

Hintelmann, H., Keppel-Jones, K., Evans, R.D., 2000. Constants of mercury methylation and demethylation rates in sediments and comparison of tracer and ambient mercury availability. Environ. Toxicol. Chem. 19, 2204-2211.

Horvat, M., Nolde, N., Fajon, V., Jereb, V., Logar, M., Lojen, S., Jacimovic, R., Falnoga, I., Liya, Q., Faganeli, J., others, 2003. Total mercury, methylmercury and selenium in mercury polluted areas in the province Guizhou, China. Sci. Total Environ. 304, 231-256.

Khush, G.S., 2005. What it will take to feed 5.0 billion rice consumers in 2030. Plant Mol. Biol. 59, 1-6. doi:10.1007/s11103-005-2159-5

Li, B., Shi, J.B., Wang, X., Meng, M., Huang, L., Qi, X.L., He, B., Ye, Z.H., 2013. Variations and constancy of mercury and methylmercury accumulation in rice grown at contaminated paddy field sites in three Provinces of China. Environ. Pollut. 181, 91-97. doi:10.1016/j.envpol.2013.06.021

Li, M., Sherman, L.S., Blum, J.D., Grandjean, P., Mikkelsen, B., Weihe, P., Sunderland, E.M., Shine, J.P., 2014. Assessing sources of human methylmercury exposure using stable mercury isotopes. Environ. Sci. Technol. 48, 8800-8806. doi:10.1021/es500340r

Li, P., Feng, X., Yuan, X., Chan, H.M., Qiu, G., Sun, G.-X., Zhu, Y.-G., 2012. Rice consumption contributes to low level methylmercury exposure in southern China. Environ. Int. 49, 18-23. doi:10.1016/j.envint.2012.08.006

Lin, C.-C., Yee, N., Barkay, T., 2012. Microbial transformations in the mercury cycle. In: Environmental Chemistry and Toxicology of Mercury. Eds: Liu, G., Cai, Y., O'Driscoll, N. John Wiley \& Sons, Inc., New York, pp. 155-191.

Lindberg, S., Dong, W., Chanton, J., Qualls, R., Meyers, T., 2005. A mechanism for bimodal emission of gaseous mercury from aquatic macrophytes. Atmos. Environ. 39, 1289-1301. doi:10.1016/j.atmosenv.2004.11.006

Liu, Y.-R., Dong, J.-X., Han, L.-L., Zheng, Y.-M., He, J.-Z., 2016. Influence of rice straw amendment on mercury methylation and nitrification in paddy soils. Environ. Pollut. 209, 53-59. doi:10.1016/j.envpol.2015.11.023

Liu, Y.-R., Yu, R.-Q., Zheng, Y.-M., He, J.-Z., 2014. Analysis of the microbial community structure by monitoring an $\mathrm{Hg}$ methylation gene (hgcA) in paddy soils along an $\mathrm{Hg}$ gradient. Appl. Environ. Microbiol. 80, 2874-2879. doi:10.1128/AEM.04225-13 
Mao, Y., Li, Y., Richards, J., Cai, Y., 2013. Investigating uptake and translocation of mercury species by sawgrass (Cladium jamaicense) using a stable isotope tracer technique. Environ. Sci. Technol. 47, 9678-9684. doi:10.1021/es400546s

Meng, B., Feng, X., Qiu, G., Anderson, C.W.N., Wang, J., Zhao, L., 2014. Localization and speciation of mercury in brown rice with implications for Pan-Asian public health. Environ. Sci. Technol. 48, 7974-7981. doi:10.1021/es502000d

Meng, B., Feng, X., Qiu, G., Cai, Y., Wang, D., Li, P., Shang, L., Sommar, J., 2010. Distribution patterns of inorganic mercury and methylmercury in tissues of rice (Oryza sativa L.) plants and possible bioaccumulation pathways. J. Agric. Food Chem. 58, 4951-4958. doi:10.1021/jf904557x

Meng, B., Feng, X., Qiu, G., Liang, P., Li, P., Chen, C., Shang, L., 2011. The process of methylmercury accumulation in rice (Oryza sativa L.). Environ. Sci. Technol. 45, 2711-2717. doi:10.1021/es103384v

Meng, B., Feng, X., Qiu, G., Wang, D., Liang, P., Li, P., Shang, L., 2012. Inorganic mercury accumulation in rice (Oryza sativa L.). Environ. Toxicol. Chem. 31, 2093-2098. doi:10.1002/etc. 1913

Munthe, J., Bodaly, R.A. (Drew), Branfireun, B.A., Driscoll, C.T., Gilmour, C.C., Harris, R., Horvat, M., Lucotte, M., Malm, O., 2007. Recovery of mercury-contaminated fisheries. AMBIO J. Hum. Environ. 36, 33-44. doi:10.1579/0044-7447(2007)36[33:ROMF]2.0.CO;2

Obrist, D., Johnson, D.W., Lindberg, S.E., Luo, Y., Hararuk, O., Bracho, R., Battles, J.J., Dail, D.B., Edmonds, R.L., Monson, R.K., Ollinger, S.V., Pallardy, S.G., Pregitzer, K.S., Todd, D.E., 2011. Mercury distribution across 14 U.S. forests. Part I: Spatial patterns of concentrations in biomass, litter, and soils. Environ. Sci. Technol. 45, 3974-3981. doi:10.1021/es104384m

Peng, X., Liu, F., Wang, W.-X., Ye, Z., 2012. Reducing total mercury and methylmercury accumulation in rice grains through water management and deliberate selection of rice cultivars. Environ. Pollut. 162, 202-208. doi:10.1016/j.envpol.2011.11.024

Rothenberg, S.E., Feng, X., 2012. Mercury cycling in a flooded rice paddy. J. Geophys. Res. 117. doi:10.1029/2011JG001800

Rothenberg, S.E., Feng, X., Dong, B., Shang, L., Yin, R., Yuan, X., 2011a. Characterization of mercury species in brown and white rice (Oryza sativa L.) grown in water-saving paddies. Environ. Pollut. 159, 1283-1289. doi:10.1016/j.envpol.2011.01.027

Rothenberg, S.E., Feng, X., Li, P., 2011b. Low-level maternal methylmercury exposure through rice ingestion and potential implications for offspring health. Environ. Pollut. 159, 1017-1022. doi:10.1016/j.envpol.2010.12.024 
Rothenberg, S.E., Feng, X., Zhou, W., Tu, M., Jin, B., You, J., 2012. Environment and genotype controls on mercury accumulation in rice (Oryza sativa L.) cultivated along a contamination gradient in Guizhou, China. Sci. Total Environ. 426, 272-280. doi:10.1016/j.scitotenv.2012.03.024

Rothenberg, S.E., Mgutshini, N.L., Bizimis, M., Johnson-Beebout, S.E., Ramanantsoanirina, A., 2015. Retrospective study of methylmercury and other metal(loid)s in Madagascar unpolished rice (Oryza sativa L.). Environ. Pollut. 196, 125-133. doi:10.1016/j.envpol.2014.10.002

Rothenberg, S.E., Windham-Myers, L., Creswell, J.E., 2014. Rice methylmercury exposure and mitigation: A comprehensive review. Environ. Res. 133, 407-423. doi:10.1016/j.envres.2014.03.001

Schwesig, D., Krebs, O., 2003. The role of ground vegetation in the uptake of mercury and methylmercury in a forest ecosystem. Plant Soil 253, 445-455.

Ullrich, S.M., Tanton, T.W., Abdrashitova, S.A., 2001. Mercury in the aquatic environment: A review of factors affecting methylation. Crit. Rev. Environ. Sci. Technol. 31, 241-293. doi:10.1080/20016491089226

Vishnivetskaya, T.A., Mosher, J.J., Palumbo, A.V., Yang, Z.K., Podar, M., Brown, S.D., Brooks, S.C., Gu, B., Southworth, G.R., Drake, M.M., Brandt, C.C., Elias, D.A., 2010. Mercury and other heavy metals influence bacterial community structure in contaminated Tennessee streams. Appl. Environ. Microbiol. 77, 302-311. doi:10.1128/AEM.01715-10

Wang, X., Li, B., Tam, N.F.-Y., Huang, L., Qi, X., Wang, H., Ye, Z., Meng, M., Shi, J., 2014. Radial oxygen loss has different effects on the accumulation of total mercury and methylmercury in rice. Plant Soil. doi:10.1007/s11104-014-2239-x

Werner, C., Schnyder, H., Cuntz, M., Keitel, C., Zeeman, M.J., Dawson, T.E., Badeck, F.-W., Brugnoli, E., Ghashghaie, J., Grams, T.E.E., Kayler, Z.E., Lakatos, M., Lee, X., Máguas, C., Ogée, J., Rascher, K.G., Siegwolf, R.T.W., Unger, S., Welker, J., Wingate, L., Gessler, A., 2012. Progress and challenges in using stable isotopes to trace plant carbon and water relations across scales. Biogeosciences 9, 3083-3111. doi:10.5194/bg-9-3083-2012

Windham-Myers, L., Fleck, J.A., Ackerman, J.T., Marvin-DiPasquale, M., Stricker, C.A., Heim, W.A., Bachand, P.A.M., Eagles-Smith, C.A., Gill, G., Stephenson, M., Alpers, C.N., 2014. Mercury cycling in agricultural and managed wetlands: A synthesis of methylmercury production, hydrologic export, and bioaccumulation from an integrated field study. Sci. Total Environ. 484, 221-231. doi:10.1016/j.scitotenv.2014.01.033

Windham-Myers, L., Marvin-DiPasquale, M., A. Stricker, C., Agee, J.L., H. Kieu, L., Kakouros, E., 2013. Mercury cycling in agricultural and managed wetlands of California, USA: Experimental 
evidence of vegetation-driven changes in sediment biogeochemistry and methylmercury production. Sci. Total Environ. doi:10.1016/j.scitotenv.2013.05.028

Windham-Myers, L., Marvin-Dipasquale, M., Krabbenhoft, D.P., Agee, J.L., Cox, M.H., HerediaMiddleton, P., Coates, C., Kakouros, E., 2009. Experimental removal of wetland emergent vegetation leads to decreased methylmercury production in surface sediment. J. Geophys. Res. 114. doi:10.1029/2008JG000815

Xu, X., Zhao, J., Li, Y., Fan, Y., Zhu, N., Gao, Y., Li, B., Liu, H., Li, Y.-F., 2016. Demethylation of methylmercury in growing rice plants: An evidence of self-detoxification. Environ. Pollut. 210, 113-120. doi:10.1016/j.envpol.2015.12.013

Xu, Y., This, D., Pausch, R.C., Vonhof, W.M., Coburn, J.R., Comstock, J.P., McCouch, S.R., 2009. Leaflevel water use efficiency determined by carbon isotope discrimination in rice seedlings: genetic variation associated with population structure and QTL mapping. Theor. Appl. Genet. 118, 10651081. doi:10.1007/s00122-009-0963-Z

Yin, R., Feng, X., Meng, B., 2013. Stable mercury isotope variation in rice plants (Oryza sativa L.) from the Wanshan Mercury Mining District, SW China. Environ. Sci. Technol. 47, 2238-2245. doi:10.1021/es304302a

Zhang, H., Feng, X., Larssen, T., Qiu, G., Vogt, R.D., 2010a. In Inland China, rice, rather than fish, is the major pathway for methylmercury exposure. Environ. Health Perspect. 118, 1183-1188. doi:10.1289/ehp.1001915

Zhang, H., Feng, X., Larssen, T., Shang, L., Li, P., 2010b. Bioaccumulation of methylmercury versus inorganic mercury in rice (Oryza sativa L.) grain. Environ. Sci. Technol. 44, 4499-4504.

Zhang, T., Kim, B., Levard, C., Reinsch, B.C., Lowry, G.V., Deshusses, M.A., Hsu-Kim, H., 2012. Methylation of mercury by bacteria exposed to dissolved, nanoparticulate, and microparticulate mercuric sulfides. Environ. Sci. Technol. 46, 6950-6958. doi:10.1021/es203181m

Zhou, J., Liu, H., Du, B., Shang, L., Yang, J., Wang, Y., 2015. Influence of soil mercury concentration and fraction on bioaccumulation process of inorganic mercury and methylmercury in rice (Oryza sativa L.). Environ. Sci. Pollut. Res. 22, 6144-6154. doi:10.1007/s11356-014-3823-6

Zhu, D.-W., Zhong, H., Zeng, Q.-L., Yin, Y., 2015. Prediction of methylmercury accumulation in rice grains by chemical extraction methods. Environ. Pollut. 199, 1-9. doi:10.1016/j.envpol.2015.01.015 


\section{Synthesis and Final Conclusions}

My graduate work has been aimed at better understanding $\mathrm{MeHg}$ production in managed wetlands, with emphasis on basic, open questions of significance to human health or improved management of wetland environments. Here, I synthesize findings across the several projects composing my thesis, and discuss their relevance to basic $\mathrm{MeHg}$ biogeochemistry, wetland management, or the accumulation of $\mathrm{Hg}$ in the human food supply.

\subsection{Relation of MeHg to specific management interventions}

Two wetland management activities were investigated in this thesis, with an attempt to better understand how specific management interventions affect $\mathrm{MeHg}$ production and accumulation in different wetland environments. The first was the effect of dredging on the $\mathrm{MeHg}$ biogeochemistry of a stormwater wetland, discussed in Chapter 3. The second, presented in Chapter 5, was a field-scale simulation of the increases and decreases in sulfate deposition associated with past industrialization and subsequent emissions regulations. These regulations are essentially broad, regional management decisions which, while not aimed at individual wetlands or even wetland types, have nonetheless been very effective at reducing sulfate pollution and associated MeHg production by wetlands (Coleman Wasik et al., 2012; Kahl et al., 2004).

In both of these situations, the response of the microbial community to disturbance was a major factor in determining how the wetland's $\mathrm{MeHg}$ biogeochemistry was affected by the management intervention. In Chapter 4, I showed that experimental increases and decreases in sulfate deposition led to significant but reversible changes in the net $\mathrm{MeHg}$ accumulation of the peatland, which were quantitatively related to concurrent changes in the Deltaproteobacterial community. From this, I inferred that legislated decreases in sulfate deposition reduced $\mathrm{MeHg}$ production not only by reducing the activity of sulfate-reducing $\mathrm{Hg}$ methylators, but also by altering their community structure. Importantly, it appears that this desirable reduction in $\mathrm{Hg}$ methylation capacity was related to the resilience of the bacterial community. After sulfate amendments ceased, the bacterial community returned to a structure that was more presumably 
similar to that present before the sulfate amendments began (Strickman et al., 2016). A similar, although less desirable resilience to disturbance was observed in the functioning of the microbial community of a dredged wetland (Chapter 3), although community structure was not directly assessed in this work. The $\mathrm{Hg}$ methylation capacity of the sediment microflora was initially very low post-dredging, but rapidly rebounded, over a period of five months, to levels more similar to those found in a nearby mature, undredged wetland (Chapter 3).

Important questions remain about the duration of these management-related changes in the $\mathrm{Hg}$ methylating microbial community. In the dredged wetland, it is unclear whether the rebound in $\mathrm{MeHg}$ production rates was complete, or if $\mathrm{MeHg}$ concentrations would continue to rise over time. The work presented in Chapter 5, which saw that MeHg was still somewhat elevated in the recovery treatment years after sulfate amendments ceased, does suggest that the effects of dredging on MeHg biogeochemistry were likely to be of a longer duration than five months. The effects of dredging on wetland $\mathrm{MeHg}$ production are of particular concern in areas with preexisting $\mathrm{MeHg}$ contamination problems, such as wetlands treating stormwater entering the Florida Everglades (Feng et al., 2014; Rumbold and Fink, 2006) or wetlands surrounding Hg contaminated ports (Figueiredo et al., 2014; Marvin-DiPasquale and Agee, 2003). It is clear that further research directly comparing $\mathrm{MeHg}$ production, and other microbial processes, in multiple wetlands before and after dredging is needed to characterize the response of the sediment microflora to this management activity.

The timing of these responses to management interventions has important implications. It is reasonable to assume that, as the structure and function (MeHg production) of the microbial community returns to a background level after a management disturbance, other functions of the microbial community would respond on a similar timescale. My results suggest that these changes would occur over a relatively short period (less than five years) in peatlands, and possibly much more rapidly in stormwater wetlands. These observations are of particular interest in the context of atmospheric deposition of sulfate, as this project simulated the effects of existing sulfate-control efforts in North America as well as those proposed for East Asia (Kim et al., 2012). My work therefore provides further support for the value of both maintaining and instituting robust sulfur dioxide emissions controls. 


\subsection{Drivers of MeHg production in small artificial wetlands stormwater wetlands}

Much of the research in this thesis has been directed at basic characterization of the extent of $\mathrm{MeHg}$ production in artificial wetlands, including stormwater wetlands, which have never previously been assessed in the peer-reviewed literature for $\mathrm{MeHg}$ production capacity. The research presented in Chapters 2 and 3 represents the first direct, stable isotope incubation measurements of $\mathrm{Hg}$ methylation in created wetlands, and confirms that in situ MeHg production occurs in these habitats. This research also comprises the most extensive exploration of $\mathrm{MeHg}$ biogeochemistry in stormwater wetlands to date, beginning with a simple description of the extent of $\mathrm{MeHg}$ concentrations and production in their sediments, relative to habitat wetlands. This work, described in Chapter 2, determined that MeHg production in stormwater wetlands was significantly lower than that in habitat wetlands, leading to concurrently lower $\mathrm{MeHg}$ concentrations in sediment. I subsequently explored this interesting pattern in much greater detail in Chapter 3, investigating the $\mathrm{MeHg}$ and associated biogeochemistry of stormwater wetlands at different stages in the management lifecycle over a growing season. Below, I synthesize my findings about the drivers of $\mathrm{MeHg}$ production and concentrations in these two types of artificial wetlands.

In both stormwater and habitat wetlands, I identified sediment organic carbon as important to both the production of $\mathrm{MeHg}$, and to the wetland's storage of $\mathrm{MeHg}$ and $\mathrm{IHg}$ (Chapters 2, 3). As newly-created stormwater wetlands are often very poor in organic matter, this pattern helps explain the low $\mathrm{MeHg}$ production in young stormwater wetlands relative to older stormwater wetlands found in both Chapters 2 and 3. This finding concurs with very recent findings from similarly low-organic-carbon, new reservoirs, which also displayed low MeHg production when young, followed by subsequent increases (Meng et al., 2016). These findings together challenge the existing paradigm that $\mathrm{MeHg}$ production is predictably high in new wetlands (Sinclair et al., 2012), and suggests that additions of organic carbon to new artificial wetlands during start-up, a common management practice (Bruland et al., 2009; David Kenth, personal communication), may be counterproductive from the perspective of $\mathrm{MeHg}$ production. 
In addition to the total amount of organic carbon in sediment, it appears that the quality of sediment organic matter helps regulate $\mathrm{MeHg}$ production in stormwater wetlands. I identified positive correlations between sediment ammonia and $\mathrm{MeHg}$ production and concentrations, which I attributed to a co-ocurrence of recently mineralized nitrogen and ammonia from pockets of high-quality organic detritus (Liu et al., 2016). However, the possibility also exists that ammonia was stimulating MeHg production more directly, by supporting the metabolism of novel nitrite-oxidizing $\mathrm{Hg}$ methylators. Although this theory is entirely speculative, the very recent discovery of marine nitrite-oxidizing $\mathrm{Hg}$ methylators (Gionfriddo et al., 2016) and the ongoing evidence of undiscovered diversity in $\mathrm{Hg}$ methylators from many habitats (Podar et al., 2015) warrant further studies of the taxonomic distribution of $\mathrm{Hg}$ methylation capacity in the stormwater wetland microflora. While not technologically possible in this thesis, further study here will be greatly supported by the very recent advent of both broad-range and clade-specific primers for the detection of the $h g c A B$ methylation gene pair in environmental samples (Christensen et al., 2016).

In addition to organic matter, I also identified significant correlations between the concentration of $\mathrm{IHg}$, and $\mathrm{MeHg}$ production and concentrations. This finding is somewhat unusual (Ullrich et al., 2001), because the bioavailability of IHg generally varies widely (Hsu-Kim et al., 2013), creating disjuncts between measured $\mathrm{IHg}$ and $\mathrm{MeHg}$ concentration. The observation that $\mathrm{IHg}$ correlates well with $\mathrm{K}_{\text {meth }}$ and $\mathrm{MeHg}$ concentrations therefore suggests an unexpectedly low variation in the bioavailability of $\mathrm{IHg}$ in stormwater sediments. This in turn suggests that $\mathrm{IHg}$ bioavailability in stormwater wetland sediments may be regulated somewhat differently than $\mathrm{IHg}$ bioavailability in other systems.

Hg methylation in stormwater wetlands is likely to be carried out by sulfate reducing bacteria, but their activity appears to be modulated by competition with nitrate reducers as well as the supply of electron acceptors. This competitive inhibition has been observed to lower $\mathrm{MeHg}$ production and accumulation in other environments (Shih et al., 2011; Todorova et al. 2009), which suggests that the relatively high levels of nitrate supplied to stormwater wetlands in Southern Ontario (Chiandet and Xenopoulos, 2016) may help to explain the low $\mathrm{MeHg}$ accumulation in stormwater wetlands. If $\mathrm{MeHg}$ production in stormwater wetlands is indeed 
dampened by inputs of nitrate, a common contaminant of stormwater runoff, then the low $\mathrm{MeHg}$ production in stormwater wetlands relative to other wetlands may be a widespread phenomenon.

Although the biotic impact of $\mathrm{MeHg}$ contamination in stormwater wetlands was not measured directly, it is possible to infer the likelihood of such effects by extrapolating from other small wetlands in similar climates and with comparable trophic structures (Chumchal and Drenner, 2015). Only one report links sediment $\mathrm{MeHg}$ and $\mathrm{THg}$ concentrations in small temperate wetlands with concentrations in invertebrates, and was conducted in artificial wetlands managed for habitat provision (Sinclair et al., 2012). This study found that in wetlands with sediment MeHg concentrations (c.1.5 ng g-1) comparable to those in the stormwater ponds studied in Chapters 2 and $3\left(0.02-2.48 \mathrm{ng} \mathrm{g}^{-1}\right)$, the concentrations of $\mathrm{MeHg}$ and $\mathrm{THg}$ in emerging invertebrates were below the thresholds for which negative reproductive effects had been observed in birds (Brasso and Cristol, 2007). This suggests that the biotic impacts of $\mathrm{MeHg}$ production in stormwater wetlands is likely to be minimal, although additional work is needed to characterize the $\mathrm{MeHg}$ concentrations at different trophic levels of the stormwater pond ecosystem, and in stormwater ponds with different trophic structures. In particular, stormwater ponds that are without fish may export higher concentrations of MeHg and THg in emerging invertebrates (Tweedy et al., 2013), a factor which should be considered in future studies.

\subsection{Impact of wetland plants on $\mathrm{MeHg}$ biogeochemistry}

The original impetus for this thesis was an interest in how plants might affect $\mathrm{MeHg}$ production in different wetlands. Evidence from many other environments has strongly indicated that plants increase $\mathrm{MeHg}$ production through the stimulation of $\mathrm{Hg}$ methylators via the release of labile organic carbon, aerobic regeneration of metabolic substrates of $\mathrm{Hg}$ methylators, and transpiration-driven concentration of solutes, including $\mathrm{MeHg}$, in the rhizosphere porewater (Bachand et al., 2014; Rothenberg et al., 2014; Windham-Myers et al., 2009). In contrast, the research in this thesis indicates that wetland plants do not necessarily stimulate $\mathrm{MeHg}$ production. In a controlled greenhouse experiment (Chapter 5), I found no increases in the percent of $\mathrm{THg}$ present as $\mathrm{MeHg}$ in vegetated compared to unvegetated mesocosms, and in fact observed a significant decrease in this measure of long-term $\mathrm{MeHg}$ accumulation in vegetated 
pots during the final weeks of the experiment. It is apparent that the densely rooted plant rhizosphere was either promoting demethylation, or inhibiting methylation and allowing background $\mathrm{MeHg}$ degradation processes to reduce the burden of $\mathrm{MeHg}$ in the sediment. Interestingly, in Chapters 2 and 3 I observed a similar absence of a stimulatory effect of plants on $\mathrm{MeHg}$ production and concentrations in working artificial wetlands, suggesting that the results presented in Chapter 5 were not simply a result of the limited root space of the vegetated pots. It

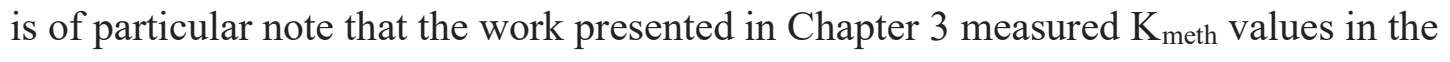
rhizosphere of living plants collected directly from the field, which is in itself a novel measurement in the literature, and found no relationship between plant size or estimates of plant activity and $\mathrm{K}_{\text {meth }}$ values. It is reasonable to assume that this method would relate $\mathrm{MeHg}$ production and concentration more directly to the rhizosphere of natural wetland plants than the comparison of vegetated and unvegetated zones (Canário et al., 2007; O’Driscoll et al., 2011; Windham-Myers et al., 2009) or from plants grown in rhizoboxes (Sun et al., 2011). Overall, the evidence I have collected points to the conclusion that plants do not consistently increase $\mathrm{MeHg}$ production and accumulation in rhizosphere sediments. Further investigations of the mechanisms behind the role of plants on $\mathrm{MeHg}$ biogeochemistry are needed, and should apply fine-scale measurements of $\mathrm{MeHg}$ methylation and demethylation in paired field and laboratory settings. I also conclude that it is unlikely that wetland vegetation in stormwater wetlands in Ontario significantly alters the $\mathrm{MeHg}$ biogeochemistry of these environments, but caution that this finding should be verified in other regions before being applied to stormwater management, particularly in areas with pre-existing $\mathrm{Hg}$ or $\mathrm{MeHg}$ contamination problems.

\subsection{Sources of $\mathrm{MeHg}$ and $\mathrm{IHg}$ to rice}

Although the majority of my work focused on the production of $\mathrm{MeHg}$, in my final research chapter I turned my attention to a particular consequence of $\mathrm{MeHg}$ production in the sediments of rice paddies, arguably the most important type of managed wetland in the world. This project, presented in Chapter 5, provided robust information on basic questions about the source and uptake timing of both $\mathrm{MeHg}$ and $\mathrm{IHg}$ to rice tissues. I paired stable isotope tracer techniques with a greenhouse cultivation experiment to provide the most conclusive evidence to date that the $\mathrm{MeHg}$ in rice grain originates in the soil, a finding which confirms previous correlation-based studies. While additional work using multiple stable isotope tracers to identify different 
environmental compartments would exclude the possibility of in planta methylation of $\mathrm{IHg}$ or direct uptake from water, my research does not support the existence of these pathways. However, I did find evidence of likely in planta demethylation, a process which has very recently been observed in living rice plants by authors employing other techniques (Xu et al., 2016). Although in planta demethylation is not part of the established understanding of MeHg transport in rice (Rothenberg et al., 2014), my work suggests that it can account for up to $30 \%$ of the MeHg taken up from the soil. This raises the possibility that cultivars could be selected for increased MeHg demethylation, as well as decreased uptake of $\mathrm{MeHg}$ (Li et al., 2013; Rothenberg et al., 2012). My findings on the timing of uptake of MeHg to rice tissues also suggests practical measures to take to reduce $\mathrm{MeHg}$ accumulation. It has been previously shown that drawing down paddy water can reduce MeHg accumulation in grain (Peng et al., 2012), a strategy that my work indicates should be timed for the pre-flowering stages, during which I observed the bulk of the MeHg translocation from soil to plant tissues.

Finally, this thesis yielded valuable insights into the sources of IHg to rice tissues, a topic of importance to food safety since IHg makes up $40-60 \%$ of the $\mathrm{Hg}$ in rice grain. Previous correlative studies have found evidence for both a soil and an atmospheric origin of IHg to rice grain, with disagreement about the relative proportions contributed by each compartment (Rothenberg et al., 2014). In this experiment, however, I found no evidence of a translocation of $\mathrm{IHg}$ from soil to rice grain, indicating that all $\mathrm{IHg}$ in rice is absorbed directly from the atmosphere, as hypothesized by previous researchers (Meng et al., 2014). Therefore, IHg in rice grains must be managed by controls on atmospheric, rather than soil-bound, concentrations of Hg.

\subsection{References}

Bachand, P.A.M., Bachand, S.M., Fleck, J.A., Alpers, C.N., Stephenson, M., Windham-Myers, L., 2014. Methylmercury production in and export from agricultural wetlands in California, USA: The need to account for physical transport processes into and out of the root zone. Sci. Total Environ. 472, 957-970. doi:10.1016/j.scitotenv.2013.11.086

Brasso, R.L., Cristol, D.A., 2007. Effects of mercury exposure on the reproductive success of tree swallows (Tachycineta bicolor). Ecotoxicol. 17, 133-141. doi:10.1007/s10646-007-0163-z 
Bruland, G.L., Richardson, C.J., Daniels, W.L., 2009. Microbial and geochemical responses to organic matter amendments in a created wetland. Wetlands 29, 1153-1165. doi:10.1672/08-201.1

Canário, J., Caetano, M., Vale, C., Cesário, R., 2007. Evidence for elevated production of methylmercury in salt marshes. Environ. Sci. Technol. 41, 7376-7382. doi:10.1021/es071078j

Chiandet, A.S., Xenopoulos, M.A., 2016. Landscape and morphometric controls on water quality in stormwater management ponds. Urban Ecosystems. doi:10.1007/s11252-016-0559-8

Christensen, G.A., Wymore, A.M., King, A.J., Podar, M., Hurt, R.A., Santillan, E.U., Soren, A., Brandt, C.C., Brown, S.D., Palumbo, A.V., Wall, J.D., Gilmour, C.C., Elias, D.A., 2016. Development and validation of broad-range qualitative and clade-specific quantitative molecular probes for assessing mercury methylation in the environment. Appl. Environ. Microbiol. AEM.01271-16. doi:10.1128/AEM.01271-16

Chumchal, M.M., Drenner, R.W., 2015. An environmental problem hidden in plain sight? Small Humanmade ponds, emergent insects, and mercury contamination of biota in the Great Plains: An environmental problem hidden in plain sight. Environ. Toxicol. Chem. 34, 1197-1205. doi:10.1002/etc. 2954

Coleman Wasik, J.K., Mitchell, C.P.J., Engstrom, D.R., Swain, E.B., Monson, B.A., Balogh, S.J., Jeremiason, J.D., Branfireun, B.A., Eggert, S.L., Kolka, R.K., Almendinger, J.E., 2012. Methylmercury declines in a boreal peatland when experimental sulfate deposition decreases. Environ. Sci. Technol. 46, 6663-6671. doi:10.1021/es300865f

Feng, S., Ai, Z., Zheng, S., Gu, B., Li, Y., 2014. Effects of dryout and inflow water quality on mercury methylation in a constructed wetland. Water. Air. Soil Pollut. 225. doi:10.1007/s11270-014-19296

Figueiredo, N.L.L., Areias, A., Mendes, R., Canário, J., Duarte, A., Carvalho, C., 2014. Mercury-resistant bacteria from salt marsh of Tagus Estuary: the influence of plants presence and mercury contamination levels. J. Toxicol. Environ. Health A 77, 959-971. doi:10.1080/15287394.2014.911136

Gionfriddo, C.M., Tate, M.T., Wick, R.R., Schultz, M.B., Zemla, A., Thelen, M.P., Schofield, R., Krabbenhoft, D.P., Holt, K.E., Moreau, J.W., 2016. Microbial mercury methylation in Antarctic sea ice. Nat. Microbiol. 1, 16127. doi:10.1038/nmicrobiol.2016.127

Hsu-Kim, H., Kucharzyk, K.H., Zhang, T., Deshusses, M.A., 2013. Mechanisms regulating mercury bioavailability for methylating microorganisms in the aquatic environment: a critical review. Environ. Sci. Technol. 130227163055006. doi:10.1021/es304370g 
Kahl, J.S., Stoddard, J.L., Haeuber, R., Paulsen, S.G., Birnbaum, R., Deviney, F.A., Webb, J.R., DeWalle, D.R., Sharpe, W., Driscoll, C.T., others, 2004. Peer Reviewed: Have US surface waters responded to the 1990 Clean Air Act Amendments? Environ. Sci. Technol. 38, 484A-490A.

Kim, C.-H., Chang, L.-S., Meng, F., Kajino, M., Ueda, H., Zhang, Y., Son, H.-Y., Lee, J.-J., He, Y., Xu, J., Sato, K., Sakurai, T., Han, Z., Duan, L., Kim, J.-S., Lee, S.-J., Song, C.-K., Ban, S.-J., Shim, S.-G., Sunwoo, Y., Lee, T.-Y., 2012. Sulfur deposition simulations over China, Japan, and Korea: a model intercomparison study for abating sulfur emission. Environ. Sci. Pollut. Res. 19, 40734089. doi:10.1007/s11356-012-1071-1

Li, B., Shi, J.B., Wang, X., Meng, M., Huang, L., Qi, X.L., He, B., Ye, Z.H., 2013. Variations and constancy of mercury and methylmercury accumulation in rice grown at contaminated paddy field sites in three Provinces of China. Environ. Pollut. 181, 91-97.

doi:10.1016/j.envpol.2013.06.021

Liu, Y.-R., Dong, J.-X., Han, L.-L., Zheng, Y.-M., He, J.-Z., 2016. Influence of rice straw amendment on mercury methylation and nitrification in paddy soils. Environ. Pollut. 209, 53-59.

doi:10.1016/j.envpol.2015.11.023

Marvin-DiPasquale, M., Agee, J.L., 2003. Microbial mercury cycling in sediments of the San Francisco Bay-Delta. Estuaries 26, 1517-1528.

Meng, B., Feng, X., Qiu, G., Anderson, C.W.N., Wang, J., Zhao, L., 2014. Localization and speciation of mercury in brown rice with implications for Pan-Asian public health. Environ. Sci. Technol. 48, 7974-7981. doi:10.1021/es502000d

Meng, B., Feng, X., Qiu, G., Li, Z., Yao, H., Shang, L., Yan, H., 2016. The impacts of organic matter on the distribution and methylation of mercury in a hydroelectric reservoir in Wujiang River, Southwest China: The influence of organic matter on mercury cycling. Environ. Toxicol. Chem. 35, 191-199. doi:10.1002/etc.3181

O’Driscoll, N.J., Canário, J., Crowell, N., Webster, T., 2011. Mercury speciation and distribution in coastal wetlands and tidal mudflats: Relationships with sulphur speciation and organic carbon. Water. Air. Soil Pollut. 220, 313-326. doi:10.1007/s11270-011-0756-2

Peng, X., Liu, F., Wang, W.-X., Ye, Z., 2012. Reducing total mercury and methylmercury accumulation in rice grains through water management and deliberate selection of rice cultivars. Environ. Pollut. 162, 202-208. doi:10.1016/j.envpol.2011.11.024

Podar, M., Gilmour, C.C., Brandt, C.C., Soren, A., Brown, S.D., Crable, B.R., Palumbo, A.V., Somenahally, A.C., Elias, D.A., 2015. Global prevalence and distribution of genes and microorganisms involved in mercury methylation. Sci. Adv. 1, e1500675-e1500675. doi:10.1126/sciadv.1500675 
Rothenberg, S.E., Feng, X., Zhou, W., Tu, M., Jin, B., You, J., 2012. Environment and genotype controls on mercury accumulation in rice (Oryza sativa L.) cultivated along a contamination gradient in Guizhou, China. Sci. Total Environ. 426, 272-280. doi:10.1016/j.scitotenv.2012.03.024

Rothenberg, S.E., Windham-Myers, L., Creswell, J.E., 2014. Rice methylmercury exposure and mitigation: A comprehensive review. Environ. Res. 133, 407-423.

doi:10.1016/j.envres.2014.03.001

Rumbold, D.G., Fink, L.E., 2006. Extreme spatial variability and unprecedented methylmercury concentrations within a constructed wetland. Environ. Monit. Assess. 112, 115-135.

Shih, R., Robertson, W.D., Schiff, S.L., Rudolph, D.L., 2011. Nitrate controls methyl mercury production in a streambed bioreactor. J. Environ. Qual. 40, 1586. doi:10.2134/jeq2011.0072

Sinclair, K.A., Xie, Q., Mitchell, C.P.J., 2012. Methylmercury in water, sediment, and invertebrates in created wetlands of Rouge Park, Toronto, Canada. Environmental Pollution 171, 207-215. doi:10.1016/j.envpol.2012.07.043

Strickman, R.J.S., Fulthorpe, R.R., Coleman Wasik, J.K., Engstrom, D.R., Mitchell, C.P.J., 2016. Experimental sulfate amendment alters peatland bacterial community structure. Sci. Total Environ. doi:10.1016/j.scitotenv.2016.05.189

Sun, X., Wang, Q., Ma, H., Wang, Z., Yang, S., Zhao, C., Xu, L., 2011. Effects of plant rhizosphere on mercury methylation in sediments. J. Soils Sediments 11, 1062-1069. doi:10.1007/s11368-0110403-y

Todorova, S. G., Driscoll, C.T., Matthews, D.A., Effler, S.W., Hines, M.E., Henry, E. A. 2009. Evidence for regulation of monomethyl mercury by nitrate in a seasonally stratified, eutrophic lake. Environ. Sci. Technol. 43, 6572-6578.

Tweedy, B.N., Drenner, R.W., Chumchal, M.M., Kennedy, J.H., 2013. Effects of fish on emergent insectmediated flux of methyl mercury across a gradient of contamination. Environ. Sci. Technol. 130116130036006. doi:10.1021/es303330m

Ullrich, S.M., Tanton, T.W., Abdrashitova, S.A., 2001. Mercury in the aquatic environment: A review of factors affecting methylation. Crit. Rev. Environ. Sci. Technol. 31, 241-293. doi:10.1080/20016491089226

Windham-Myers, L., Marvin-Dipasquale, M., Krabbenhoft, D.P., Agee, J.L., Cox, M.H., HerediaMiddleton, P., Coates, C., Kakouros, E., 2009. Experimental removal of wetland emergent vegetation leads to decreased methylmercury production in surface sediment. J. Geophys. Res. 114. doi:10.1029/2008JG000815 
Xu, X., Zhao, J., Li, Y., Fan, Y., Zhu, N., Gao, Y., Li, B., Liu, H., Li, Y.-F., 2016. Demethylation of methylmercury in growing rice plants: An evidence of self-detoxification. Environ. Pollut. 210, 113-120. doi:10.1016/j.envpol.2015.12.013 


\section{Appendices}

7.1 Appendix 1: Additional material for Chapter 4: Experimental sulfate amendment alters peatland bacterial community structure

7.1.1 Supplmementary Table 7.1.1: Quality control data for $\mathrm{MeHg}$ and $\mathrm{THg}$ analyses

Supplementary Table 1: Quality control data for MeHg and THg analyses

\begin{tabular}{lcc}
\hline & MeHg & THg \\
\hline Reference Material Recovery (\%) & $97 \pm 5^{1}$ & $109 \pm 1$ \\
Replicate RSD (\%) & $4 \pm 4$ & $6 \pm 2$ \\
Spike Recovery (\%) & $\mathrm{n} / \mathrm{a}^{2}$ & $95 \pm 2$ \\
\hline${ }^{1}$ Standard reference material for MeHg = IAEA-405; for THg = MESS-3. & \\
${ }^{2} \mathrm{n} / \mathrm{a}=$ not applicable &
\end{tabular}




\subsubsection{Supplementary Table 7.1.2: Phylum-level Taxonomic Affiliation of Bacterial SSU rRNA amplicon reads}

Supplmentary Table 2: Phylum-level Taxonomic Affiliation of Bacterial SSU rRNA amplicon reads (weighted abundance)

\begin{tabular}{|c|c|c|c|c|c|c|c|c|c|c|c|c|c|c|c|c|c|c|}
\hline \multirow{2}{*}{$\begin{array}{l}\text { Treatment } \\
\text { Replicate }\end{array}$} & \multicolumn{3}{|c|}{ Control Lagg } & \multicolumn{3}{|c|}{ Control Bog } & \multicolumn{3}{|c|}{ Experimental Lagg } & \multicolumn{3}{|c|}{ Experimental Bog } & \multicolumn{3}{|c|}{ Recovery Lagg } & \multicolumn{3}{|c|}{ Recovery Bog } \\
\hline & 1 & 2 & 3 & 1 & 2 & 3 & 1 & 2 & 3 & 1 & 2 & 3 & 1 & 2 & 3 & 1 & 2 & 3 \\
\hline Number of high-quality sequences & 10365 & 10996 & 10369 & 13110 & 11669 & 9986 & 11657 & 11233 & 11547 & 10254 & 12152 & 8810 & 11964 & 12584 & 9720 & 11035 & 11549 & 8662 \\
\hline Number of OTUs & 2017 & 2193 & 2228 & 2270 & 1863 & 1920 & 1834 & 2044 & 1806 & 1642 & 1723 & 1833 & 2140 & 1990 & 2098 & 1480 & 1549 & 1617 \\
\hline \multicolumn{19}{|l|}{ Phylum or Candidate Phylum } \\
\hline Acidobacteria & 0.1301 & 0.1706 & 0.1384 & 0.2379 & 0.2947 & 0.2351 & 0.2337 & 0.2704 & 0.2860 & 0.2586 & 0.3332 & 0.2931 & 0.2212 & 0.2006 & 0.1890 & 0.2591 & 0.3562 & 0.3343 \\
\hline Actinobacteria & 0.1428 & 0.1762 & 0.1812 & 0.1347 & 0.0485 & 0.0740 & 0.1172 & 0.0560 & 0.0607 & 0.0793 & 0.0822 & 0.0666 & 0.0740 & 0.1194 & 0.0889 & 0.1543 & 0.1133 & 0.0349 \\
\hline$A D 3$ & 0.0020 & 0.0043 & 0.0029 & 0.0124 & 0.0012 & 0.0020 & 0.0104 & 0.0077 & 0.0020 & 0.0092 & 0.0086 & 0.0106 & 0.0007 & 0.0052 & 0.0056 & 0.0043 & 0.0010 & 0.0005 \\
\hline Armatimonadetes & 0.0043 & 0.0029 & 0.0049 & 0.0050 & 0.0044 & 0.0031 & 0.0015 & 0.0012 & 0.0049 & 0.0103 & 0.0064 & 0.0074 & 0.0024 & 0.0021 & 0.0016 & 0.0005 & 0.0029 & 0.0010 \\
\hline Bacteroidetes & 0.0138 & 0.0137 & 0.0264 & 0.0076 & 0.0147 & 0.0129 & 0.0045 & 0.0103 & 0.0133 & 0.0055 & 0.0088 & 0.0111 & 0.0117 & 0.0077 & 0.0094 & 0.0051 & 0.0070 & 0.0079 \\
\hline$B R C 1$ & 0.0007 & 0.0004 & 0.0009 & 0.0001 & 0.0003 & 0.0009 & 0.0005 & 0.0002 & 0.0010 & 0.0011 & 0.0005 & 0.0007 & 0.0001 & 0.0000 & 0.0001 & 0.0010 & 0.0003 & 0.0002 \\
\hline Chlorobi & 0.0029 & 0.0040 & 0.0021 & 0.0019 & 0.0011 & 0.0005 & 0.0024 & 0.0033 & 0.0043 & 0.0000 & 0.0010 & 0.0031 & 0.0108 & 0.0065 & 0.0210 & 0.0011 & 0.0018 & 0.0022 \\
\hline Chloroflexi & 0.0245 & 0.0163 & 0.0165 & 0.0085 & 0.0099 & 0.0081 & 0.0074 & 0.0120 & 0.0060 & 0.0095 & 0.0059 & 0.0094 & 0.0301 & 0.0180 & 0.0405 & 0.0091 & 0.0072 & 0.0009 \\
\hline Cyanobacteria & 0.0105 & 0.0066 & 0.0202 & 0.0224 & 0.0319 & 0.0440 & 0.0139 & 0.0147 & 0.0083 & 0.0204 & 0.0218 & 0.0160 & 0.0037 & 0.0040 & 0.0133 & 0.0120 & 0.0337 & 0.0630 \\
\hline Elusimicrobia & 0.0041 & 0.0043 & 0.0034 & 0.0028 & 0.0034 & 0.0015 & 0.0042 & 0.0052 & 0.0050 & 0.0025 & 0.0014 & 0.0043 & 0.0043 & 0.0055 & 0.0075 & 0.0016 & 0.0006 & 0.0021 \\
\hline Firmicutes & 0.0053 & 0.0042 & 0.0035 & 0.0042 & 0.0071 & 0.0083 & 0.0038 & 0.0085 & 0.0035 & 0.0126 & 0.0188 & 0.0098 & 0.0035 & 0.0033 & 0.0071 & 0.0121 & 0.0096 & 0.0058 \\
\hline Gemmatimonadetes & 0.0039 & 0.0023 & 0.0011 & 0.0011 & 0.0009 & 0.0006 & 0.0024 & 0.0017 & 0.0040 & 0.0002 & 0.0009 & 0.0009 & 0.0015 & 0.0014 & 0.0009 & 0.0004 & 0.0008 & 0.0007 \\
\hline Lentisphaerae & 0.0000 & 0.0000 & 0.0000 & 0.0000 & 0.0000 & 0.0000 & 0.0000 & 0.0000 & 0.0000 & 0.0000 & 0.0002 & 0.0000 & 0.0000 & 0.0000 & 0.0000 & 0.0000 & 0.0000 & 0.0000 \\
\hline NC10 & 0.0001 & 0.0000 & 0.0000 & 0.0001 & 0.0000 & 0.0000 & 0.0002 & 0.0001 & 0.0000 & 0.0000 & 0.0000 & 0.0000 & 0.0000 & 0.0004 & 0.0003 & 0.0000 & 0.0000 & 0.0000 \\
\hline Nitrospirae & 0.0025 & 0.0022 & 0.0003 & 0.0002 & 0.0000 & 0.0002 & 0.0003 & 0.0002 & 0.0000 & 0.0000 & 0.0000 & 0.0003 & 0.0010 & 0.0017 & 0.0017 & 0.0001 & 0.0001 & 0.0001 \\
\hline$O P 3$ & 0.0023 & 0.0009 & 0.0013 & 0.0006 & 0.0011 & 0.0024 & 0.0017 & 0.0022 & 0.0028 & 0.0019 & 0.0020 & 0.0043 & 0.0017 & 0.0007 & 0.0020 & 0.0003 & 0.0010 & 0.0017 \\
\hline Planctomycetes & 0.0251 & 0.0188 & 0.0180 & 0.0288 & 0.0264 & 0.0267 & 0.0269 & 0.0151 & 0.0217 & 0.0349 & 0.0196 & 0.0292 & 0.0186 & 0.0322 & 0.0152 & 0.0261 & 0.0277 & 0.0180 \\
\hline Proteobacteria & 0.5246 & 0.4871 & 0.4502 & 0.4228 & 0.3849 & 0.4346 & 0.4465 & 0.4394 & 0.4501 & 0.4125 & 0.3657 & 0.4050 & 0.4509 & 0.4810 & 0.4444 & 0.3458 & 0.3067 & 0.3848 \\
\hline SC3 & 0.0015 & 0.0010 & 0.0004 & 0.0008 & 0.0009 & 0.0010 & 0.0009 & 0.0003 & 0.0002 & 0.0000 & 0.0005 & 0.0001 & 0.0003 & 0.0017 & 0.0002 & 0.0001 & 0.0011 & 0.0001 \\
\hline SC4 & 0.0001 & 0.0003 & 0.0000 & 0.0000 & 0.0000 & 0.0002 & 0.0003 & 0.0002 & 0.0002 & 0.0000 & 0.0000 & 0.0002 & 0.0001 & 0.0002 & 0.0001 & 0.0005 & 0.0003 & 0.0003 \\
\hline SM2F11 & 0.0007 & 0.0009 & 0.0002 & 0.0003 & 0.0003 & 0.0001 & 0.0001 & 0.0003 & 0.0000 & 0.0005 & 0.0007 & 0.0001 & 0.0005 & 0.0003 & 0.0007 & 0.0000 & 0.0001 & 0.0000 \\
\hline Spirochaetes & 0.0040 & 0.0018 & 0.0005 & 0.0006 & 0.0020 & 0.0012 & 0.0013 & 0.0021 & 0.0004 & 0.0002 & 0.0010 & 0.0000 & 0.0061 & 0.0027 & 0.0037 & 0.0012 & 0.0001 & 0.0000 \\
\hline Tenericutes & 0.0002 & 0.0000 & 0.0000 & 0.0000 & 0.0000 & 0.0000 & 0.0000 & 0.0000 & 0.0000 & 0.0000 & 0.0000 & 0.0000 & 0.0000 & 0.0000 & 0.0000 & 0.0000 & 0.0000 & 0.0000 \\
\hline TG3 & 0.0000 & 0.0002 & 0.0000 & 0.0000 & 0.0000 & 0.0000 & 0.0000 & 0.0001 & 0.0000 & 0.0000 & 0.0000 & 0.0000 & 0.0005 & 0.0000 & 0.0008 & 0.0000 & 0.0001 & 0.0000 \\
\hline TM6 & 0.0097 & 0.0045 & 0.0036 & 0.0055 & 0.0040 & 0.0059 & 0.0036 & 0.0064 & 0.0042 & 0.0065 & 0.0086 & 0.0159 & 0.0048 & 0.0028 & 0.0078 & 0.0065 & 0.0131 & 0.0055 \\
\hline TM7 & 0.0039 & 0.0016 & 0.0038 & 0.0024 & 0.0067 & 0.0053 & 0.0057 & 0.0044 & 0.0025 & 0.0074 & 0.0102 & 0.0087 & 0.0038 & 0.0039 & 0.0078 & 0.0172 & 0.0089 & 0.0028 \\
\hline Unclassified Bacteria & 0.0375 & 0.0369 & 0.0398 & 0.0278 & 0.0422 & 0.0322 & 0.0279 & 0.0367 & 0.0295 & 0.0311 & 0.0211 & 0.0261 & 0.0496 & 0.0434 & 0.0381 & 0.0256 & 0.0307 & 0.0283 \\
\hline Verrucomicrobia & 0.0291 & 0.0223 & 0.0384 & 0.0404 & 0.0521 & 0.0566 & 0.0409 & 0.0490 & 0.0559 & 0.0463 & 0.0319 & 0.0385 & 0.0670 & 0.0292 & 0.0609 & 0.0423 & 0.0282 & 0.0502 \\
\hline WPS-2 & 0.0132 & 0.0154 & 0.0414 & 0.0296 & 0.0600 & 0.0399 & 0.0398 & 0.0523 & 0.0332 & 0.0495 & 0.0481 & 0.0381 & 0.0306 & 0.0254 & 0.0310 & 0.0733 & 0.0473 & 0.0544 \\
\hline WS1 & 0.0000 & 0.0000 & 0.0000 & 0.0000 & 0.0000 & 0.0000 & 0.0000 & 0.0000 & 0.0000 & 0.0000 & 0.0000 & 0.0000 & 0.0001 & 0.0000 & 0.0001 & 0.0000 & 0.0000 & 0.0000 \\
\hline ws3 & 0.0002 & 0.0001 & 0.0000 & 0.0000 & 0.0000 & 0.0000 & 0.0006 & 0.0000 & 0.0000 & 0.0000 & 0.0000 & 0.0000 & 0.0000 & 0.0000 & 0.0002 & 0.0000 & 0.0000 & 0.0000 \\
\hline Nonbacterial & 0.0005 & 0.0002 & 0.0009 & 0.0015 & 0.0013 & 0.0026 & 0.0016 & 0.0003 & 0.0005 & 0.0000 & 0.0010 & 0.0005 & 0.0005 & 0.0009 & 0.0000 & 0.0005 & 0.0003 & 0.0002 \\
\hline
\end{tabular}

level, but which could not be assigned to a known grouping (undescribed) are indicated by a terminal c _ , o , or $\mathrm{f}$ 


\subsubsection{Supplmementary Table 7.1.3: Class-level Taxonomic Affiliation of Bacterial SSU rRNA amplicon reads (weighted abundance)}

Supplementary Table 3 page 1 of 3: Class-level Taxonomic Affiliation of Bacterial SSU rRNA amplicon reads (weighted abundance)

\begin{tabular}{|c|c|c|c|c|c|c|c|c|c|c|c|c|c|c|c|c|c|c|c|}
\hline & \multirow{2}{*}{$\begin{array}{l}\text { Treatment } \\
\text { Replicate }\end{array}$} & \multicolumn{3}{|c|}{ Control Lagg } & \multicolumn{3}{|c|}{ Control Bog } & \multicolumn{3}{|c|}{ Experimental Lagg } & \multicolumn{3}{|c|}{ Experimental Bog } & \multicolumn{3}{|c|}{ Recovery Lagg } & \multicolumn{3}{|c|}{ Recovery Bog } \\
\hline & & 1 & 2 & 3 & 1 & 2 & 3 & 1 & 2 & 3 & 1 & 2 & 3 & 1 & 2 & 3 & 1 & 2 & 3 \\
\hline & Number of clean sequences & 10365 & 10996 & 10369 & 13110 & 11669 & 9986 & 11657 & 11233 & 11547 & 10254 & 12152 & 8810 & 11964 & 12584 & 9720 & 11035 & 11549 & 8662 \\
\hline & Number of OTUs & 2017 & 2193 & 2228 & 2270 & 1863 & 1920 & 1834 & 2044 & 1806 & 1642 & 1723 & 1833 & 2140 & 1990 & 2098 & 1480 & 1549 & 1617 \\
\hline Phylum & Class & & & & & & & & & & & & & & & & & & \\
\hline Bacteria & Unidentified Bacteria & 0.0375 & 0.0369 & 0.0398 & 0.0278 & 0.0422 & 0.0322 & 0.0279 & 0.0367 & 0.0295 & 0.0311 & 0.0211 & 0.0261 & 0.0496 & 0.0434 & 0.0381 & 0.0256 & 0.0307 & 0.0283 \\
\hline \multirow[t]{9}{*}{ Acidobacteria } & Unidentified class & 0.0437 & 0.0721 & 0.0417 & 0.1112 & 0.0636 & 0.0592 & 0.0914 & 0.0876 & 0.0794 & 0.1036 & 0.0929 & 0.0980 & 0.0612 & 0.0805 & 0.0849 & 0.0892 & 0.1070 & 0.1074 \\
\hline & Acidobacteria & 0.0347 & 0.0469 & 0.0519 & 0.0753 & 0.1717 & 0.1201 & 0.0924 & 0.1221 & 0.1566 & 0.1037 & 0.1960 & 0.1603 & 0.0703 & 0.0474 & 0.0478 & 0.1346 & 0.1934 & 0.1791 \\
\hline & Acidobacteria-5 & 0.0001 & 0.0006 & 0.0005 & 0.0003 & 0.0001 & 0.0004 & 0.0006 & 0.0004 & 0.0004 & 0.0001 & 0.0007 & 0.0001 & 0.0004 & 0.0009 & 0.0004 & 0.0000 & 0.0005 & 0.0007 \\
\hline & Holophagae & 0.0246 & 0.0078 & 0.0110 & 0.0109 & 0.0377 & 0.0324 & 0.0144 & 0.0288 & 0.0186 & 0.0041 & 0.0061 & 0.0064 & 0.0483 & 0.0381 & 0.0171 & 0.0067 & 0.0151 & 0.0272 \\
\hline & iii1-8 & 0.0043 & 0.0068 & 0.0040 & 0.0008 & 0.0001 & 0.0001 & 0.0011 & 0.0002 & 0.0000 & 0.0000 & 0.0000 & 0.0000 & 0.0022 & 0.0016 & 0.0006 & 0.0000 & 0.0000 & 0.0000 \\
\hline & MVS-40 & 0.0000 & 0.0000 & 0.0000 & 0.0000 & 0.0000 & 0.0000 & 0.0001 & 0.0001 & 0.0000 & 0.0000 & 0.0000 & 0.0000 & 0.0001 & 0.0000 & 0.0000 & 0.0000 & 0.0000 & 0.0000 \\
\hline & Solibacteres & 0.0178 & 0.0294 & 0.0241 & 0.0370 & 0.0199 & 0.0210 & 0.0318 & 0.0288 & 0.0273 & 0.0413 & 0.0345 & 0.0252 & 0.0356 & 0.0283 & 0.0347 & 0.0272 & 0.0370 & 0.0174 \\
\hline & Sva0725 & 0.0015 & 0.0019 & 0.0009 & 0.0000 & 0.0000 & 0.0000 & 0.0000 & 0.0000 & 0.0000 & 0.0000 & 0.0002 & 0.0000 & 0.0014 & 0.0002 & 0.0002 & 0.0000 & 0.0000 & 0.0000 \\
\hline & Other & 0.0032 & 0.0050 & 0.0044 & 0.0024 & 0.0017 & 0.0019 & 0.0018 & 0.0023 & 0.0036 & 0.0059 & 0.0028 & 0.0032 & 0.0018 & 0.0036 & 0.0033 & 0.0014 & 0.0032 & 0.0025 \\
\hline Actinobacteria & Unidentified Actinobacteria & 0.1428 & 0.1762 & 0.1812 & 0.1347 & 0.0485 & 0.0740 & 0.1172 & 0.0560 & 0.0607 & 0.0793 & 0.0822 & 0.0666 & 0.0740 & 0.1194 & 0.0889 & 0.1543 & 0.1133 & 0.0349 \\
\hline \multirow[t]{2}{*}{$A D 3$} & ABS-6 & 0.0001 & 0.0002 & 0.0002 & 0.0000 & 0.0000 & 0.0000 & 0.0000 & 0.0000 & 0.0000 & 0.0003 & 0.0000 & 0.0000 & 0.0000 & 0.0000 & 0.0001 & 0.0000 & 0.0000 & 0.0000 \\
\hline & JG37-AG-4 & 0.0019 & 0.0041 & 0.0027 & 0.0124 & 0.0012 & 0.0020 & 0.0104 & 0.0077 & 0.0020 & 0.0089 & 0.0086 & 0.0106 & 0.0007 & 0.0052 & 0.0055 & 0.0043 & 0.0010 & 0.0005 \\
\hline \multirow[t]{5}{*}{ Armatimonadetes } & Armatimonadia & 0.0006 & 0.0001 & 0.0016 & 0.0007 & 0.0011 & 0.0003 & 0.0000 & 0.0000 & 0.0010 & 0.0030 & 0.0018 & 0.0027 & 0.0007 & 0.0007 & 0.0001 & 0.0002 & 0.0003 & 0.0007 \\
\hline & $\mathrm{CH} 21$ & 0.0025 & 0.0014 & 0.0028 & 0.0029 & 0.0015 & 0.0018 & 0.0015 & 0.0009 & 0.0031 & 0.0047 & 0.0041 & 0.0034 & 0.0010 & 0.0006 & 0.0005 & 0.0003 & 0.0023 & 0.0002 \\
\hline & Chthonomonadetes & 0.0011 & 0.0014 & 0.0005 & 0.0009 & 0.0017 & 0.0008 & 0.0000 & 0.0001 & 0.0008 & 0.0026 & 0.0005 & 0.0010 & 0.0004 & 0.0004 & 0.0005 & 0.0001 & 0.0001 & 0.0001 \\
\hline & SJA-176 & 0.0002 & 0.0000 & 0.0000 & 0.0001 & 0.0000 & 0.0002 & 0.0000 & 0.0002 & 0.0000 & 0.0000 & 0.0000 & 0.0000 & 0.0003 & 0.0003 & 0.0005 & 0.0000 & 0.0002 & 0.0000 \\
\hline & Unidentified Armatimonadetes & 0.0000 & 0.0001 & 0.0000 & 0.0004 & 0.0000 & 0.0000 & 0.0000 & 0.0000 & 0.0000 & 0.0000 & 0.0000 & 0.0002 & 0.0000 & 0.0000 & 0.0000 & 0.0000 & 0.0000 & 0.0000 \\
\hline \multirow[t]{5}{*}{ Bacteroidetes } & Unidentified class & 0.0000 & 0.0001 & 0.0001 & 0.0001 & 0.0003 & 0.0003 & 0.0001 & 0.0002 & 0.0006 & 0.0001 & 0.0002 & 0.0000 & 0.0000 & 0.0003 & 0.0001 & 0.0000 & 0.0000 & 0.0001 \\
\hline & Bacteroidia & 0.0012 & 0.0004 & 0.0003 & 0.0000 & 0.0005 & 0.0002 & 0.0005 & 0.0004 & 0.0000 & 0.0000 & 0.0000 & 0.0000 & 0.0021 & 0.0006 & 0.0020 & 0.0000 & 0.0002 & 0.0002 \\
\hline & Flavobacteria & 0.0015 & 0.0008 & 0.0014 & 0.0000 & 0.0000 & 0.0000 & 0.0000 & 0.0007 & 0.0000 & 0.0000 & 0.0000 & 0.0000 & 0.0000 & 0.0000 & 0.0000 & 0.0000 & 0.0000 & 0.0000 \\
\hline & Sphingobacteria & 0.0086 & 0.0088 & 0.0217 & 0.0063 & 0.0117 & 0.0100 & 0.0032 & 0.0069 & 0.0096 & 0.0036 & 0.0058 & 0.0062 & 0.0060 & 0.0054 & 0.0040 & 0.0023 & 0.0045 & 0.0048 \\
\hline & Unidentified Bacteriodetes & 0.0025 & 0.0036 & 0.0030 & 0.0012 & 0.0022 & 0.0024 & 0.0008 & 0.0021 & 0.0030 & 0.0018 & 0.0028 & 0.0049 & 0.0036 & 0.0014 & 0.0033 & 0.0028 & 0.0023 & 0.0027 \\
\hline \multirow[t]{2}{*}{$B R C 1$} & Unidentified class & 0.0003 & 0.0002 & 0.0007 & 0.0001 & 0.0003 & 0.0009 & 0.0005 & 0.0002 & 0.0010 & 0.0011 & 0.0005 & 0.0007 & 0.0001 & 0.0000 & 0.0001 & 0.0010 & 0.0003 & 0.0002 \\
\hline & PRR-11 & 0.0004 & 0.0002 & 0.0002 & 0.0000 & 0.0000 & 0.0000 & 0.0000 & 0.0000 & 0.0000 & 0.0000 & 0.0000 & 0.0000 & 0.0000 & 0.0000 & 0.0000 & 0.0000 & 0.0000 & 0.0000 \\
\hline \multirow[t]{5}{*}{ Chlorobi } & BSV19 & 0.0014 & 0.0004 & 0.0003 & 0.0015 & 0.0007 & 0.0000 & 0.0007 & 0.0010 & 0.0000 & 0.0000 & 0.0000 & 0.0000 & 0.0067 & 0.0042 & 0.0181 & 0.0000 & 0.0000 & 0.0000 \\
\hline & Ignavibacteria & 0.0002 & 0.0002 & 0.0004 & 0.0000 & 0.0000 & 0.0000 & 0.0002 & 0.0008 & 0.0000 & 0.0000 & 0.0000 & 0.0000 & 0.0005 & 0.0002 & 0.0002 & 0.0008 & 0.0000 & 0.0007 \\
\hline & OPB56 & 0.0004 & 0.0002 & 0.0001 & 0.0000 & 0.0000 & 0.0000 & 0.0000 & 0.0000 & 0.0000 & 0.0000 & 0.0000 & 0.0000 & 0.0010 & 0.0007 & 0.0002 & 0.0000 & 0.0000 & 0.0000 \\
\hline & SJA-28 & 0.0004 & 0.0004 & 0.0000 & 0.0000 & 0.0000 & 0.0000 & 0.0000 & 0.0000 & 0.0000 & 0.0000 & 0.0000 & 0.0000 & 0.0000 & 0.0000 & 0.0000 & 0.0000 & 0.0000 & 0.0000 \\
\hline & SM1B09 & 0.0006 & 0.0029 & 0.0014 & 0.0004 & 0.0004 & 0.0005 & 0.0015 & 0.0015 & 0.0043 & 0.0000 & 0.0010 & 0.0031 & 0.0026 & 0.0014 & 0.0025 & 0.0003 & 0.0018 & 0.0015 \\
\hline
\end{tabular}

could not be assigned to a known grouping (undescribed) are indicated by a terminal $\mathrm{c}, \mathrm{o}$, or $\mathrm{f}$ 
Supplementary Table 3 page 2 of 3: Class-level Taxonomic Affiliation of Bacterial SSU rRNA amplicon reads (weighted abundance)

\begin{tabular}{|c|c|c|c|c|c|c|c|c|c|c|c|c|c|c|c|c|c|c|c|}
\hline & \multirow{2}{*}{$\begin{array}{l}\text { Treatment } \\
\text { Replicate }\end{array}$} & \multicolumn{3}{|c|}{ Control Lagg } & \multicolumn{3}{|c|}{ Control Bog } & \multicolumn{3}{|c|}{ Experimental Lagg } & \multicolumn{3}{|c|}{ Experimental Bog } & \multicolumn{3}{|c|}{ Recovery Lagg } & \multicolumn{3}{|c|}{ Recovery Bog } \\
\hline & & 1 & & 3 & 1 & 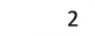 & 3 & 1 & 2 & 3 & 1 & 2 & 3 & 1 & 2 & 3 & 1 & 2 & \\
\hline & Number of clean sequences & 10365 & 10996 & 10369 & 13110 & 11669 & 9986 & 11657 & 11233 & 11547 & 10254 & 12152 & 8810 & 11964 & 12584 & 9720 & 11035 & 11549 & 8662 \\
\hline & Number of OTUs & 2017 & 2193 & 2228 & 2270 & 1863 & 1920 & 1834 & 2044 & 1806 & 1642 & 1723 & 1833 & 2140 & 1990 & 2098 & 1480 & 1549 & 1617 \\
\hline Phylum & Class & & & & & & & & & & & & & & & & & & \\
\hline \multirow{7}{*}{ Chloroflexi } & Anaerolineae & 0.0108 & 0.0054 & 0.0025 & 0.0043 & 0.0013 & 0.0030 & 0.0057 & 0.0086 & 0.0026 & 0.0011 & 0.0000 & 0.0000 & 0.0150 & 0.0090 & 0.0259 & 0.0053 & 0.0011 & 0.0000 \\
\hline & Bljii12 & 0.0005 & 0.0007 & 0.0005 & 0.0000 & 0.0000 & 0.0000 & 0.0004 & 0.0000 & 0.0000 & 0.0000 & 0.0000 & 0.0000 & 0.0000 & 0.0001 & 0.0001 & 0.0000 & 0.0000 & 0.0000 \\
\hline & Dehalococcoidetes & 0.0001 & 0.0001 & 0.0000 & 0.0000 & 0.0000 & 0.0000 & 0.0000 & 0.0000 & 0.0000 & 0.0000 & 0.0000 & 0.0000 & 0.0003 & 0.0000 & 0.0001 & 0.0000 & 0.0000 & 0.0000 \\
\hline & Ktedonobacteria & 0.0032 & 0.0043 & 0.0078 & 0.0022 & 0.0082 & 0.0045 & 0.0003 & 0.0016 & 0.0033 & 0.0077 & 0.0055 & 0.0089 & 0.0067 & 0.0043 & 0.0009 & 0.0009 & 0.0034 & 0.0009 \\
\hline & RA13C7 & 0.0000 & 0.0000 & 0.0000 & 0.0000 & 0.0000 & 0.0000 & 0.0000 & 0.0000 & 0.0000 & 0.0000 & 0.0000 & 0.0000 & 0.0000 & 0.0001 & 0.0003 & 0.0000 & 0.0000 & 0.0000 \\
\hline & TK17 & 0.0009 & 0.0010 & 0.0002 & 0.0000 & 0.0000 & 0.0000 & 0.0000 & 0.0000 & 0.0000 & 0.0000 & 0.0000 & 0.0000 & 0.0000 & 0.0004 & 0.0000 & 0.0000 & 0.0000 & 0.0000 \\
\hline & Undefined Chloroflexi & 0.0011 & 0.0004 & 0.0003 & 0.0006 & 0.0002 & 0.0001 & 0.0001 & 0.0003 & 0.0001 & 0.0006 & 0.0003 & 0.0005 & 0.0024 & 0.0010 & 0.0055 & 0.0029 & 0.0027 & 0.0000 \\
\hline \multirow[t]{6}{*}{ Cyanobacteria } & $4 \mathrm{COd}-2$ & 0.0025 & 0.0014 & 0.0018 & 0.0024 & 0.0033 & 0.0041 & 0.0012 & 0.0036 & 0.0015 & 0.0022 & 0.0012 & 0.0020 & 0.0012 & 0.0028 & 0.0011 & 0.0014 & 0.0042 & 0.0029 \\
\hline & Chloroplast & 0.0075 & 0.0041 & 0.0178 & 0.0110 & 0.0196 & 0.0317 & 0.0122 & 0.0101 & 0.0064 & 0.0129 & 0.0148 & 0.0111 & 0.0019 & 0.0005 & 0.0119 & 0.0083 & 0.0230 & 0.0523 \\
\hline & Nostocophycideae & 0.0000 & 0.0000 & 0.0000 & 0.0000 & 0.0000 & 0.0000 & 0.0001 & 0.0003 & 0.0000 & 0.0000 & 0.0000 & 0.0000 & 0.0003 & 0.0002 & 0.0000 & 0.0000 & 0.0021 & 0.0069 \\
\hline & Oscilla & 0.0000 & 0.0000 & 0.0000 & 0.0000 & 0.0000 & 0.0000 & 0.0000 & 0.0000 & 0.0000 & 0.0000 & 0.0000 & 0.0000 & 0.0000 & 0.0002 & 0.0000 & 0.0000 & 0.0000 & 0.0000 \\
\hline & S15B-N & 0.0003 & 0.0001 & 0.0001 & 0.0000 & 0.0000 & 0.0000 & 0.0000 & 0.0002 & 0.0000 & 0.0002 & 0.0000 & 0.0001 & 0.0000 & 0.0001 & 0.0001 & 0.0004 & 0.0003 & 0.0000 \\
\hline & Unde & 0.0002 & 0.0011 & 0.0004 & 0.0091 & 0.0090 & 0.0081 & 0.0004 & 0.0004 & 0.0004 & 0.0051 & 0.0058 & 0.0027 & 0.0003 & 0.0002 & 0.0001 & 0.0019 & 0.0042 & 0.0009 \\
\hline Elusimicrobia & Elusimicrobia & 0.0041 & 0.0043 & 0.0034 & 0.0028 & 0.0034 & 0.0015 & 0.0042 & 0.0052 & 0.0050 & 0.0025 & 0.0014 & 0.0043 & 0.0043 & 0.0055 & 0.0075 & 0.0016 & 0.0006 & 0.0021 \\
\hline \multirow[t]{2}{*}{ Firmicutes } & Bacilli & 0.0026 & 0.0013 & 0.0005 & 0.0023 & 0.0039 & 0.0052 & 0.0026 & 0.0028 & 0.0032 & 0.0037 & 0.0067 & 0.0060 & 0.0008 & 0.0011 & 0.0016 & 0.0060 & 0.0055 & 0.0021 \\
\hline & Clostridia & 0.0027 & 0.0028 & 0.0030 & 0.0019 & 0.0033 & 0.0031 & 0.0012 & 0.0057 & 0.0003 & 0.0089 & 0.0120 & 0.0036 & 0.0027 & 0.0022 & 0.0055 & 0.0054 & 0.0042 & 0.0033 \\
\hline Gemmatimonadetes & Gemma & 0.0039 & 0.0023 & 0.0011 & 0.0011 & 0.0009 & 0.0006 & 0.0024 & 0.0017 & 0.0040 & 0.0002 & 0.0009 & 0.0009 & 0.0015 & 0.0014 & 0.0009 & 0.0004 & 0.0008 & 0.0007 \\
\hline Lentisphaerae & Unidentified class & 0.0000 & 0.0000 & 0.0000 & 0.0000 & 0.0000 & 0.0000 & 0.0000 & 0.0000 & 0.0000 & 0.0000 & 0.0002 & 0.0000 & 0.0000 & 0.0000 & 0.0000 & 0.0000 & 0.0000 & 0.0000 \\
\hline NC10 & $12-24$ & 0.0001 & 0.0000 & 0.0000 & 0.0001 & 0.0000 & 0.0000 & 0.0002 & 0.0001 & 0.0000 & 0.0000 & 0.0000 & 0.0000 & 0.0000 & 0.0004 & 0.0003 & 0.0000 & 0.0000 & 0.0000 \\
\hline Nitrospirae & Nitrospira & 0.0025 & 0.0022 & 0.0003 & 0.0002 & 0.0000 & 0.0002 & 0.0003 & 0.0002 & 0.0000 & 0.0000 & 0.0000 & 0.0003 & 0.0010 & 0.0017 & 0.0017 & 0.0001 & 0.0001 & 0.0001 \\
\hline$O P 3$ & koll11 & 0.0023 & 0.0009 & 0.0013 & 0.0006 & 0.0011 & 0.0024 & 0.0017 & 0.0022 & 0.0028 & 0.0019 & 0.0020 & 0.0043 & 0.0017 & 0.0007 & 0.0020 & 0.0003 & 0.0010 & 0.0017 \\
\hline \multirow[t]{5}{*}{ Planctomycetes } & Phycisphaerae & 0.0025 & 0.0025 & 0.0016 & 0.0034 & 0.0029 & 0.0033 & 0.0026 & 0.0020 & 0.0036 & 0.0040 & 0.0018 & 0.0078 & 0.0009 & 0.0015 & 0.0019 & 0.0013 & 0.0028 & 0.0022 \\
\hline & Planctomycea & 0.0224 & 0.0156 & 0.0161 & 0.0246 & 0.0235 & 0.0229 & 0.0243 & 0.0132 & 0.0179 & 0.0304 & 0.0174 & 0.0213 & 0.0176 & 0.0307 & 0.0134 & 0.0248 & 0.0249 & 0.0158 \\
\hline & PW285 & 0.0001 & 0.0006 & 0.0003 & 0.0006 & 0.0000 & 0.0005 & 0.0000 & 0.0000 & 0.0001 & 0.0005 & 0.0002 & 0.0000 & 0.0002 & 0.0000 & 0.0000 & 0.0000 & 0.0001 & 0.0000 \\
\hline & vadinHA49 & 0.0001 & 0.0001 & 0.0000 & 0.0000 & 0.0000 & 0.0000 & 0.0000 & 0.0000 & 0.0000 & 0.0000 & 0.0000 & 0.0000 & 0.0000 & 0.0000 & 0.0000 & 0.0000 & 0.0000 & 0.0000 \\
\hline & Unidentified & 0.0000 & 0.0000 & 0.0000 & 0.0001 & 0.0000 & 0.0000 & 0.0000 & 0.0000 & 0.0000 & 0.0000 & 0.0001 & 0.0000 & 0.0000 & 0.0000 & 0.0000 & 0.0000 & 0.0000 & 0.0000 \\
\hline \multirow[t]{5}{*}{ Proteobacteria } & Alphaproteobacteria & 0.3957 & 0.3584 & 0.3189 & 0.3118 & 0.2759 & 0.3040 & 0.3057 & 0.3218 & 0.2957 & 0.2910 & 0.2312 & 0.2581 & 0.3072 & 0.3484 & 0.2959 & 0.2461 & 0.2146 & 0.2903 \\
\hline & Betaproteobacteria & 0.0346 & 0.0370 & 0.0324 & 0.0140 & 0.0127 & 0.0204 & 0.0225 & 0.0183 & 0.0256 & 0.0176 & 0.0148 & 0.0196 & 0.0191 & 0.0227 & 0.0189 & 0.0043 & 0.0052 & 0.0085 \\
\hline & Deltaproteobacteria & 0.0512 & 0.0427 & 0.0466 & 0.0465 & 0.0366 & 0.0487 & 0.0584 & 0.0454 & 0.0572 & 0.0464 & 0.0515 & 0.0439 & 0.0662 & 0.0561 & 0.0780 & 0.0556 & 0.0414 & 0.0254 \\
\hline & Gammaproteobacteria & 0.0403 & 0.0442 & 0.0448 & 0.0455 & 0.0547 & 0.0496 & 0.0539 & 0.0475 & 0.0678 & 0.0527 & 0.0596 & 0.0767 & 0.0563 & 0.0495 & 0.0462 & 0.0365 & 0.0408 & 0.0539 \\
\hline & Unidentified Proteobacteria & 0.0027 & 0.0047 & 0.0074 & 0.0050 & 0.0050 & 0.0119 & 0.0061 & 0.0063 & 0.0036 & 0.0049 & 0.0086 & 0.0066 & 0.0022 & 0.0043 & 0.0055 & 0.0032 & 0.0048 & 0.0066 \\
\hline$S C 3$ & & 0.0015 & 0.0010 & 0.0004 & 0.0008 & 0.0009 & 0.0010 & 0.0009 & 0.0003 & 0.0002 & 0.0000 & 0.0005 & 0.0001 & 0.0003 & 0.0017 & 0.0002 & 0.0001 & 0.0011 & 0.0001 \\
\hline \multirow[t]{2}{*}{ SC4 } & Unidentified class & 0.0000 & 0.0003 & 0.0000 & 0.0000 & 0.0000 & 0.0002 & 0.0000 & 0.0002 & 0.0000 & 0.0000 & 0.0000 & 0.0000 & 0.0000 & 0.0000 & 0.0000 & 0.0000 & 0.0000 & 0.0000 \\
\hline & KD3-113 & 0.0001 & 0.0000 & 0.0000 & 0.0000 & 0.0000 & 0.0000 & 0.0003 & 0.0000 & 0.0002 & 0.0000 & 0.0000 & 0.0002 & 0.0001 & 0.0002 & 0.0001 & 0.0005 & 0.0003 & 0.0003 \\
\hline$S M 2 F 11$ & & & 0.0009 & 0.0002 & & 0.0003 & 0.0001 & 0.0001 & 0.0003 & 0.0000 & 0.0005 & 0.0007 & 0.0001 & 0.0005 & 0.0003 & 0.0007 & 0.0000 & 0.0001 & 0.0000 \\
\hline Spirochaetes & Spirochaetes & 0.0040 & 0.0018 & 0.0005 & 0.0006 & 0.0020 & 0.0012 & 0.0013 & 0.0021 & 0.0004 & 0.0002 & 0.0010 & 0.0000 & 0.0061 & 0.0027 & 0.0037 & 0.0012 & 0.0001 & 0.0000 \\
\hline Tenericutes & Unidentified class & 0.0002 & 0.0000 & 0.0000 & 0.0000 & 0.0000 & 0.0000 & 0.0000 & 0.0000 & 0.0000 & 0.0000 & 0.0000 & 0.0000 & 0.0000 & 0.0000 & 0.0000 & 0.0000 & 0.0000 & 0.0000 \\
\hline
\end{tabular}


Supplementary Table 3 page 3 of 3: Class-level Taxonomic Affiliation of Bacterial SSU rRNA amplicon reads (weighted abundance) $\begin{array}{llllllllllll}\text { Treatment } & \text { Control Lagg } & & \text { Control Bog } & \text { Experimental Lagg } & \text { Experimental Bog } & \text { Recovery Lagg } & \text { Recovery Bog }\end{array}$ \begin{tabular}{lrrrrrrrrrrrrrrrrrrrr} 
Replicate & 1 & 2 & 3 & 1 & 2 & 3 & 1 & 2 & 3 & 1 & 2 & 3 & 1 & 2 & 3 & 1 & 2 & 3 \\
Number of clean sequences & 10365 & 10996 & 10369 & 13110 & 11669 & 9986 & 11657 & 11233 & 11547 & 10254 & 12152 & 8810 & 11964 & 12584 & 9720 & 11035 & 11549 & 8662 \\
Number of OTUs & 2017 & 2193 & 2228 & 2270 & 1863 & 1920 & 1834 & 2044 & 1806 & 1642 & 1723 & 1833 & 2140 & 1990 & 2098 & 1480 & 1549 & 1617 \\
\hline
\end{tabular}

\begin{tabular}{|c|c|c|c|c|c|c|c|c|c|c|c|c|c|c|c|c|c|c|c|}
\hline & Number of OTUs & 2017 & 2193 & 2228 & 2270 & 1863 & 1920 & 1834 & 2044 & 1806 & 1642 & 1723 & 1833 & 2140 & 1990 & 2098 & 1480 & 1549 & 1617 \\
\hline Phylum & Class & & & & & & & & & & & & & & & & & & \\
\hline \multirow[t]{2}{*}{$\overline{T G 3}$} & TG3-1 & 0.0000 & 0.0000 & 0.0000 & 0.0000 & 0.0000 & 0.0000 & 0.0000 & 0.0001 & 0.0000 & 0.0000 & 0.0000 & 0.0000 & 0.0005 & 0.0000 & 0.0008 & 0.0000 & 0.0001 & 0.0000 \\
\hline & Unidentified TG3 & 0.0000 & 0.0002 & 0.0000 & 0.0000 & 0.0000 & 0.0000 & 0.0000 & 0.0000 & 0.0000 & 0.0000 & 0.0000 & 0.0000 & 0.0000 & 0.0000 & 0.0000 & 0.0000 & 0.0000 & 0.0000 \\
\hline \multirow[t]{3}{*}{ TM6 } & SBRH58 & 0.0000 & 0.0000 & 0.0000 & 0.0000 & 0.0000 & 0.0000 & 0.0000 & 0.0000 & 0.0002 & 0.0000 & 0.0000 & 0.0001 & 0.0000 & 0.0000 & 0.0000 & 0.0000 & 0.0000 & 0.0000 \\
\hline & SJA-4 & 0.0097 & 0.0045 & 0.0036 & 0.0053 & 0.0040 & 0.0059 & 0.0036 & 0.0062 & 0.0039 & 0.0062 & 0.0086 & 0.0156 & 0.0033 & 0.0021 & 0.0077 & 0.0065 & 0.0126 & 0.0055 \\
\hline & Unidentified TM6 & 0.0000 & 0.0001 & 0.0000 & 0.0002 & 0.0000 & 0.0000 & 0.0000 & 0.0002 & 0.0001 & 0.0003 & 0.0000 & 0.0002 & 0.0015 & 0.0006 & 0.0001 & 0.0000 & 0.0005 & 0.0000 \\
\hline \multirow[t]{3}{*}{ TM7 } & TM7-1 & 0.0035 & 0.0013 & 0.0034 & 0.0021 & 0.0062 & 0.0042 & 0.0054 & 0.0039 & 0.0016 & 0.0066 & 0.0096 & 0.0081 & 0.0018 & 0.0024 & 0.0055 & 0.0171 & 0.0088 & 0.0018 \\
\hline & TM7-3 & 0.0000 & 0.0001 & 0.0001 & 0.0001 & 0.0000 & 0.0002 & 0.0000 & 0.0003 & 0.0005 & 0.0000 & 0.0002 & 0.0007 & 0.0000 & 0.0002 & 0.0000 & 0.0000 & 0.0000 & 0.0002 \\
\hline & Unidentified TM7 & 0.0004 & 0.0003 & 0.0003 & 0.0002 & 0.0005 & 0.0009 & 0.0003 & 0.0002 & 0.0004 & 0.0008 & 0.0003 & 0.0000 & 0.0019 & 0.0014 & 0.0024 & 0.0001 & 0.0001 & 0.0007 \\
\hline \multirow[t]{7}{*}{ Verrucomicrobia } & Unidentified class & 0.0003 & 0.0000 & 0.0000 & 0.0000 & 0.0002 & 0.0000 & 0.0000 & 0.0000 & 0.0000 & 0.0000 & 0.0000 & 0.0000 & 0.0002 & 0.0000 & 0.0000 & 0.0000 & 0.0000 & 0.0000 \\
\hline & Methylacidiphilae & 0.0002 & 0.0001 & 0.0007 & 0.0006 & 0.0009 & 0.0053 & 0.0003 & 0.0004 & 0.0008 & 0.0012 & 0.0006 & 0.0007 & 0.0000 & 0.0009 & 0.0000 & 0.0006 & 0.0011 & 0.0005 \\
\hline & Opitutae & 0.0149 & 0.0107 & 0.0109 & 0.0336 & 0.0414 & 0.0385 & 0.0326 & 0.0406 & 0.0446 & 0.0208 & 0.0229 & 0.0288 & 0.0569 & 0.0212 & 0.0526 & 0.0274 & 0.0211 & 0.0384 \\
\hline & Spartobacteria & 0.0029 & 0.0020 & 0.0038 & 0.0013 & 0.0014 & 0.0015 & 0.0004 & 0.0004 & 0.0015 & 0.0020 & 0.0005 & 0.0008 & 0.0002 & 0.0006 & 0.0001 & 0.0015 & 0.0003 & 0.0008 \\
\hline & Verruco-5 & 0.0000 & 0.0000 & 0.0000 & 0.0002 & 0.0000 & 0.0000 & 0.0000 & 0.0001 & 0.0000 & 0.0000 & 0.0000 & 0.0000 & 0.0000 & 0.0000 & 0.0000 & 0.0000 & 0.0000 & 0.0000 \\
\hline & Verrucomicrobiae & 0.0096 & 0.0078 & 0.0185 & 0.0039 & 0.0078 & 0.0101 & 0.0051 & 0.0062 & 0.0081 & 0.0169 & 0.0072 & 0.0072 & 0.0078 & 0.0049 & 0.0063 & 0.0082 & 0.0040 & 0.0083 \\
\hline & Unidentified Verrucomicrobia & 0.0014 & 0.0016 & 0.0045 & 0.0008 & 0.0004 & 0.0012 & 0.0026 & 0.0013 & 0.0010 & 0.0055 & 0.0007 & 0.0010 & 0.0019 & 0.0016 & 0.0020 & 0.0045 & 0.0017 & 0.0022 \\
\hline WPS-2 & Unidentified class & 0.0132 & 0.0154 & 0.0414 & 0.0296 & 0.0600 & 0.0399 & 0.0398 & 0.0523 & 0.0332 & 0.0495 & 0.0481 & 0.0381 & 0.0306 & 0.0254 & 0.0310 & 0.0733 & 0.0473 & 0.0544 \\
\hline WS1 & Unidentified class & 0.0000 & 0.0000 & 0.0000 & 0.0000 & 0.0000 & 0.0000 & 0.0000 & 0.0000 & 0.0000 & 0.0000 & 0.0000 & 0.0000 & 0.0001 & 0.0000 & 0.0001 & 0.0000 & 0.0000 & 0.0000 \\
\hline ws3 & PRR-12 & 0.0002 & 0.0001 & 0.0000 & 0.0000 & 0.0000 & 0.0000 & 0.0006 & 0.0000 & 0.0000 & 0.0000 & 0.0000 & 0.0000 & 0.0000 & 0.0000 & 0.0002 & 0.0000 & 0.0000 & 0.0000 \\
\hline Root & & 0.0005 & 0.0002 & 0.0009 & 0.0015 & 0.0013 & 0.0026 & 0.0016 & 0.0003 & 0.0005 & 0.0000 & 0.0010 & 0.0005 & 0.0005 & 0.0009 & 0.0000 & 0.0005 & 0.0003 & 0.0002 \\
\hline
\end{tabular}




\subsubsection{Supplmementary Table 7.1.4: Order-level Taxonomic Affiliation of Bacterial SSU rRNA amplicon reads (weighted abundance)}

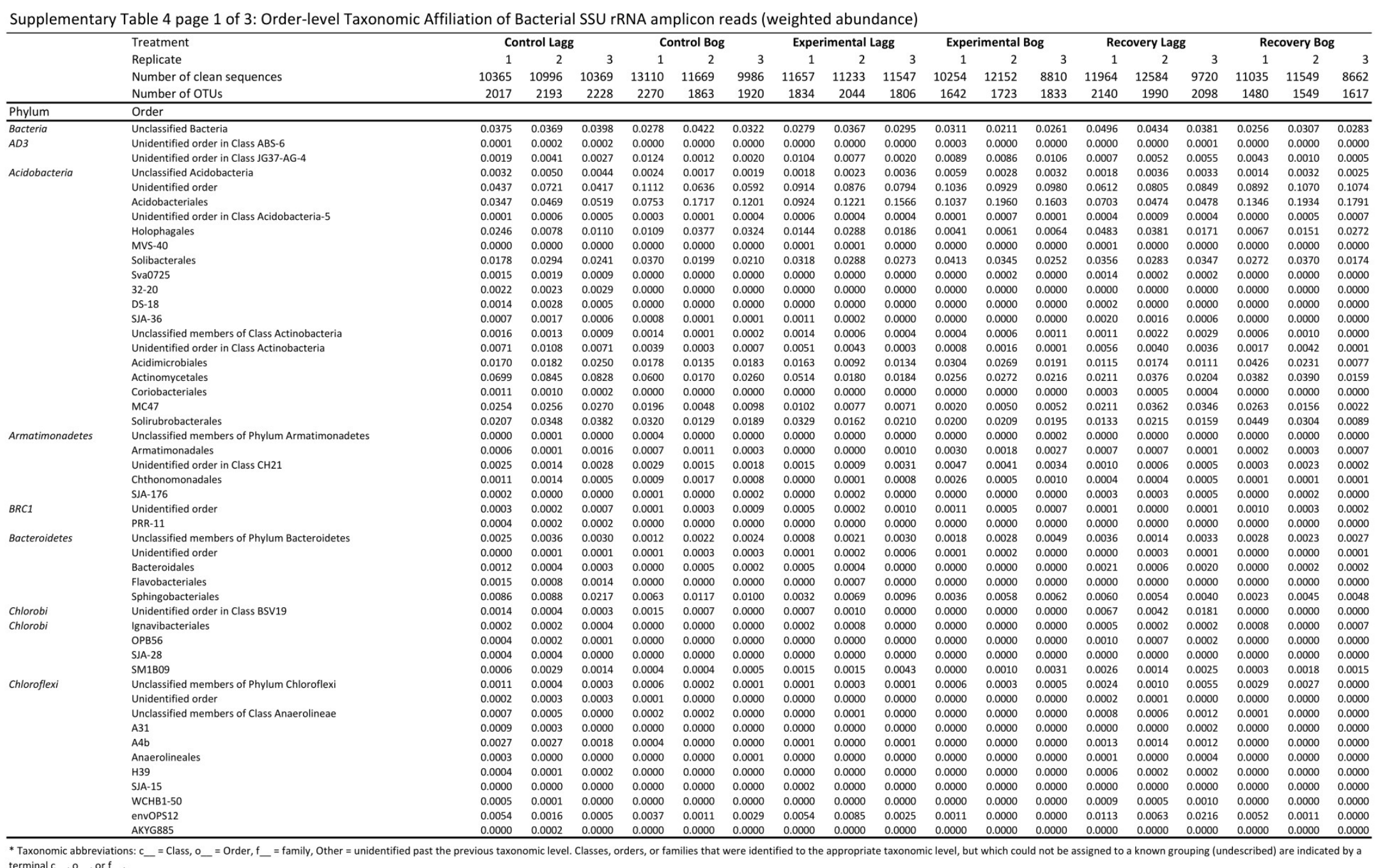


Supplementary Table 4 page 2 of 3: Order-level Taxonomic Affiliation of Bacterial SSU rRNA amplicon reads (weighted abundance) $\begin{array}{cccc}\text { Treatment } & \text { Control lagg } & \text { Control Bog } & \text { Experimental lagg }\end{array}$

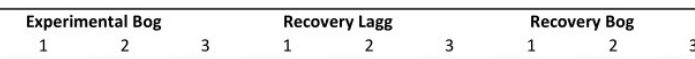
Number of clean sequences

\begin{tabular}{rrrrrrrrrrrrrrrrrr}
10365 & 10996 & 10369 & 13110 & 11669 & 9986 & 11657 & 11233 & 11547 & 10254 & 12152 & 8810 & 11964 & 12584 & 9720 & 11035 & 11549 & 8662 \\
2017 & 2193 & 2228 & 2270 & 1863 & 1920 & 1834 & 2044 & 1806 & 1642 & 1723 & 1833 & 2140 & 1990 & 2098 & 1480 & 1549 & 1617 \\
\hline
\end{tabular}


Supplementary Table 4 page 3 of 3: Order-level Taxonomic Affiliation of Bacterial SSU rRNA amplicon reads (weighted abundance)

\begin{tabular}{|c|c|c|c|c|c|c|c|c|c|c|c|c|c|c|c|c|c|c|c|}
\hline & \multirow{4}{*}{$\begin{array}{l}\text { Treatment } \\
\text { Replicate } \\
\text { Number of clean sequences } \\
\text { Number of OTUs }\end{array}$} & \multicolumn{3}{|c|}{ Control Lagg } & \multicolumn{3}{|c|}{ Control Bog } & \multicolumn{3}{|c|}{ Experimental Lagg } & \multicolumn{3}{|c|}{ Experimental Bog } & \multicolumn{3}{|c|}{ Recovery Lagg } & \multicolumn{3}{|c|}{ Recovery Bog } \\
\hline & & 1 & 2 & 3 & 1 & & 3 & & 2 & 3 & & & 3 & 1 & & 3 & 1 & & 3 \\
\hline & & 10365 & 10996 & 10369 & 13110 & 11669 & 9986 & 11657 & 11233 & 11547 & 10254 & 12152 & 8810 & 11964 & 12584 & 9720 & 11035 & 11549 & 8662 \\
\hline & & 2017 & 2193 & 2228 & 2270 & 1863 & 1920 & 1834 & 2044 & 1806 & 1642 & 1723 & 1833 & 2140 & 1990 & 2098 & 1480 & 1549 & 1617 \\
\hline Phylum & & & & & & & & & & & & & & & & & & & \\
\hline \multirow[t]{18}{*}{$\frac{1}{\text { Proteobacteria }}$} & Rhodospirillales & 0.0699 & 0.0734 & 0.0636 & 0.0501 & 0.0848 & 0.0823 & 0.0688 & 0.0823 & 0.0987 & 0.0982 & 0.0722 & 0.0642 & 0.0606 & 0.0693 & 0.0561 & 0.0795 & 0.0668 & 0.1078 \\
\hline & Rickettsiales & 0.0000 & 0.0000 & 0.0001 & 0.0002 & 0.0003 & 0.0000 & 0.0000 & 0.0000 & 0.0000 & 0.0001 & 0.0000 & 0.0000 & 0.0001 & 0.0000 & 0.0000 & 0.0000 & 0.0000 & 0.0000 \\
\hline & Sphingomonadales & 0.0006 & 0.0014 & 0.0018 & 0.0003 & 0.0002 & 0.0038 & 0.0003 & 0.0010 & 0.0009 & 0.0002 & 0.0001 & 0.0002 & 0.0005 & 0.0000 & 0.0004 & 0.0010 & 0.0009 & 0.0024 \\
\hline & CTDO05-82B-02 & 0.0003 & 0.0000 & 0.0002 & 0.0002 & 0.0000 & 0.0003 & 0.0000 & 0.0001 & 0.0008 & 0.0000 & 0.0000 & 0.0000 & 0.0003 & 0.0002 & 0.0000 & 0.0006 & 0.0000 & 0.0000 \\
\hline & Desulfovibrionales & 0.0001 & 0.0001 & 0.0001 & 0.0002 & 0.0000 & 0.0002 & 0.0001 & 0.0004 & 0.0007 & 0.0025 & 0.0006 & 0.0008 & 0.0001 & 0.0002 & 0.0004 & 0.0000 & 0.0003 & 0.0000 \\
\hline & Desulfuromonadales & 0.0050 & 0.0024 & 0.0045 & 0.0041 & 0.0004 & 0.0025 & 0.0015 & 0.0040 & 0.0021 & 0.0007 & 0.0007 & 0.0012 & 0.0031 & 0.0030 & 0.0016 & 0.0013 & 0.0003 & 0.0017 \\
\hline & MIZ46 & 0.0024 & 0.0023 & 0.0024 & 0.0059 & 0.0071 & 0.0080 & 0.0060 & 0.0039 & 0.0061 & 0.0020 & 0.0037 & 0.0033 & 0.0044 & 0.0046 & 0.0048 & 0.0129 & 0.0111 & 0.0029 \\
\hline & Myxococcales & 0.0370 & 0.0324 & 0.0343 & 0.0324 & 0.0257 & 0.0354 & 0.0445 & 0.0319 & 0.0449 & 0.0343 & 0.0433 & 0.0355 & 0.0522 & 0.0430 & 0.0655 & 0.0359 & 0.0259 & 0.0185 \\
\hline & Syntrophobacterales & 0.0048 & 0.0045 & 0.0029 & 0.0032 & 0.0009 & 0.0013 & 0.0043 & 0.0033 & 0.0018 & 0.0059 & 0.0028 & 0.0015 & 0.0035 & 0.0033 & 0.0046 & 0.0033 & 0.0011 & 0.0013 \\
\hline & Unclassified members of Class Gammaproteobacteria & 0.0020 & 0.0032 & 0.0038 & 0.0026 & 0.0044 & 0.0052 & 0.0009 & 0.0039 & 0.0023 & 0.0028 & 0.0081 & 0.0065 & 0.0033 & 0.0032 & 0.0022 & 0.0029 & 0.0019 & 0.0020 \\
\hline & Chromatiales & 0.0199 & 0.0240 & 0.0301 & 0.0310 & 0.0383 & 0.0336 & 0.0457 & 0.0289 & 0.0417 & 0.0392 & 0.0370 & 0.0471 & 0.0287 & 0.0312 & 0.0235 & 0.0250 & 0.0275 & 0.0361 \\
\hline & Enterobacteriales & 0.0000 & 0.0004 & 0.0002 & 0.0001 & 0.0000 & 0.0003 & 0.0000 & 0.0000 & 0.0000 & 0.0005 & 0.0000 & 0.0005 & 0.0000 & 0.0001 & 0.0001 & 0.0000 & 0.0002 & 0.0000 \\
\hline & Legionellales & 0.0098 & 0.0071 & 0.0041 & 0.0059 & 0.0080 & 0.0040 & 0.0036 & 0.0108 & 0.0063 & 0.0062 & 0.0084 & 0.0120 & 0.0079 & 0.0072 & 0.0136 & 0.0060 & 0.0084 & 0.0113 \\
\hline & Methylococcales & 0.0004 & 0.0010 & 0.0004 & 0.0005 & 0.0001 & 0.0005 & 0.0003 & 0.0004 & 0.0010 & 0.0002 & 0.0000 & 0.0003 & 0.0028 & 0.0009 & 0.0007 & 0.0000 & 0.0000 & 0.0006 \\
\hline & & 0.0002 & 0.0000 & 0.0000 & 0.0000 & 0.0002 & 0.0000 & 0.0000 & 0.0000 & 0.0002 & 0.0000 & 0.0000 & 0.0000 & 0.0009 & 0.0002 & 0.0000 & 0.0000 & 0.0003 & 0.0000 \\
\hline & eudomonadales & 0.0010 & 0.0006 & 0.0003 & 0.0002 & 0.0008 & 0.0007 & 0.0000 & 0.0002 & 0.0011 & 0.0006 & 0.0009 & 0.0005 & 0.0002 & 0.0000 & 0.0001 & 0.0003 & 0.0000 & 0.0005 \\
\hline & Thiotrichales & 0.0010 & 0.0005 & 0.0005 & 0.0014 & 0.0011 & 0.0011 & 0.0005 & 0.0006 & 0.0014 & 0.0010 & 0.0019 & 0.0023 & 0.0007 & 0.0017 & 0.0021 & 0.0011 & 0.0018 & 0.0030 \\
\hline & Xanthomonadales & 0.0061 & 0.0074 & 0.0056 & 0.0039 & 0.0019 & 0.0041 & 0.0027 & 0.0027 & 0.0139 & 0.0021 & 0.0032 & 0.0076 & 0.0119 & 0.0051 & 0.0040 & 0.0013 & 0.0007 & 0.0005 \\
\hline \multirow[t]{2}{*}{ SC3 } & Unidentified order & 0.0015 & 0.0010 & 0.0004 & 0.0008 & 0.0009 & 0.0010 & 0.0009 & 0.0003 & 0.0002 & 0.0000 & 0.0005 & 0.0001 & 0.0003 & 0.0017 & 0.0002 & 0.0001 & 0.0011 & 0.0001 \\
\hline & 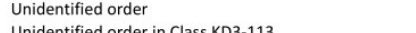 & 0.0000 & 0.0003 & 0.0000 & 0.0000 & 0.0000 & 0.0002 & 0.0000 & 0.0002 & 0.0000 & 0.0000 & 0.0000 & 0.0000 & 0.0000 & 0.0000 & 0.0000 & 0.0000 & 0.0000 & 0.0000 \\
\hline$S M 2 E 11$ & $\begin{array}{l}\text { Unidentified order in Class KD3-113 } \\
\text { Unidentified order }\end{array}$ & 0.0001 & 0.0000 & 0.0000 & 0.0000 & 0.0000 & 0.0000 & 0.0003 & 0.0000 & 0.0002 & 0.0000 & 0.0000 & 0.0002 & 0.0001 & 0.0002 & 0.0001 & 0.0005 & 0.0003 & 0.0003 \\
\hline $\begin{array}{l}\text { SM2F11 } \\
\text { Spirochaetes }\end{array}$ & $\begin{array}{l}\text { Unidentified order } \\
\text { Spiritchaetales }\end{array}$ & 0.0007 & $\begin{array}{l}0.0009 \\
0.0018\end{array}$ & $\begin{array}{l}0.0002 \\
0.005\end{array}$ & $\begin{array}{l}0.0003 \\
0.006\end{array}$ & 0.0003 & 0.0001 & 0.0001 & 0.0003 & 0.0000 & 0.0005 & 0.0007 & 0.0001 & 0.0005 & 0.0003 & 0.0007 & 0.0000 & 0.0001 & 0.0000 \\
\hline \multirow{2}{*}{ TG3 } & $\begin{array}{l}\text { Spiricchaeatales } \\
\text { Unclassified members of Phylum TG3 }\end{array}$ & $\begin{array}{l}0.0040 \\
0.0000\end{array}$ & $\begin{array}{l}0.0018 \\
0.0002\end{array}$ & $\begin{array}{l}0.0005 \\
0.0000\end{array}$ & $\begin{array}{l}0.0006 \\
0.0000\end{array}$ & $\begin{array}{l}0.0020 \\
0.0000\end{array}$ & 0.0012 & $\begin{array}{l}0.0013 \\
0.0000\end{array}$ & 0.0021 & $\begin{array}{l}0.0004 \\
0.0000\end{array}$ & 0.0002 & 0.0010 & & 0.0061 & 0.0027 & 0.0037 & 0.0012 & 0.0001 & 0.0000 \\
\hline & $\begin{array}{l}\text { Unclassified members of Phylum IG3 } \\
\text { Unclassified members of Class TG3-1 }\end{array}$ & 0.0000 & 0.0000 & 0.0000 & 0.0000 & 0.0000 & 0.0000 & $\begin{array}{l}0.0000 \\
0.0000\end{array}$ & 0.0000 & 0.0000 & 0.0000 & 0.00000 & 0.0000 & 0.00005 & 0.0000 & 0.0000 & 0.0000 & 0.0000 & 0.0000 \\
\hline \multirow{3}{*}{ TM6 } & Unclassified members of Phylum TM6 & 0.0000 & 0.0001 & 0.0000 & 0.0002 & 0.0000 & 0.0000 & 0.0000 & 0.0002 & 0.0001 & 0.0003 & 0.0000 & 0.0002 & 0.0015 & 0.0006 & 0.0001 & 0.0000 & 0.0005 & 0.0000 \\
\hline & SBRH58 & 0.0000 & 0.0000 & 0.0000 & 0.0000 & 0.0000 & 0.0000 & 0.0000 & 0.0000 & 0.0002 & 0.0000 & 0.0000 & 0.0001 & 0.0000 & 0.0000 & 0.0000 & 0.0000 & 0.0000 & 0.0000 \\
\hline & SJA-4 & 0.0097 & 0.0045 & 0.0036 & 0.0053 & 0.0040 & 0.0059 & 0.0036 & 0.0062 & 0.0039 & 0.0062 & 0.0086 & 0.0156 & 0.0033 & 0.0021 & 0.0077 & 0.0065 & 0.0126 & 0.0055 \\
\hline \multirow[t]{5}{*}{ TM7 } & Unclassified members of Phylum TM7 & 0.0004 & 0.0003 & 0.0003 & 0.0002 & 0.0005 & 0.0009 & 0.0003 & 0.0002 & 0.0004 & 0.0008 & 0.0003 & 0.0000 & 0.0019 & 0.0014 & 0.0024 & 0.0001 & 0.0001 & 0.0007 \\
\hline & & 0.0035 & 0.0013 & 0.0034 & 0.0021 & 0.0062 & 0.0042 & 0.0054 & 0.0039 & 0.0016 & 0.0066 & 0.0096 & 0.0081 & 0.0018 & 0.0024 & 0.0055 & 0.0171 & 0.0088 & 0.0018 \\
\hline & issified members of Class TM7-3 & 0.0000 & 0.0000 & 0.0000 & 0.0000 & 0.0000 & 0.0001 & 0.0000 & 0.0000 & 0.0003 & 0.0000 & 0.0000 & 0.0000 & 0.0000 & 0.0000 & 0.0000 & 0.0000 & 0.0000 & 0.0000 \\
\hline & & 0.0000 & 0.0001 & 0.0001 & 0.0001 & 0.0000 & 0.0001 & 0.0000 & 0.0000 & 0.0003 & 0.0000 & 0.0002 & 0.0007 & 0.0000 & 0.0002 & 0.0000 & 0.0000 & 0.0000 & 0.0002 \\
\hline & & 0.0000 & 0.0000 & 0.0000 & 0.0000 & 0.0000 & 0.0000 & 0.0000 & 0.0003 & 0.0000 & 0.0000 & 0.0000 & 0.0000 & 0.0000 & 0.0000 & 0.0000 & 0.0000 & 0.0000 & 0.0000 \\
\hline Tenericutes & Unidentified order & 0.0002 & 0.0000 & 0.0000 & 0.0000 & 0.0000 & 0.0000 & 0.0000 & 0.0000 & 0.0000 & 0.0000 & 0.0000 & 0.0000 & 0.0000 & 0.0000 & 0.0000 & 0.0000 & 0.0000 & 0.0000 \\
\hline \multirow[t]{5}{*}{ Verrucomicrobia } & Unclassified members of Phylum Verrucomicrobia & 0.0014 & 0.0016 & 0.0045 & 0.0008 & 0.0004 & 0.0012 & 0.0026 & 0.0013 & 0.0010 & 0.0055 & 0.0007 & 0.0010 & 0.0019 & 0.0016 & 0.0020 & 0.0045 & 0.0017 & 0.0022 \\
\hline & 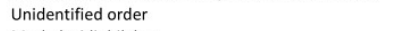 & 0.0003 & 0.0000 & 0.0000 & 0.0000 & 0.0002 & 0.0000 & 0.0000 & 0.0000 & 0.0000 & .0000 & 0.0000 & 0.0000 & 0.0002 & 0.0000 & 0.0000 & 0.0000 & 0.0000 & 0.0000 \\
\hline & & 0.0002 & 0.0001 & & 0.0006 & 0.0009 & 0.0053 & 0.00 & 0.0004 & 88 & 0012 & 0006 & 0.0007 & 0.0000 & 0.0009 & 0.00 & 06 & 0.00 & 0.0005 \\
\hline & ified members of Class Opitutae & 0.0003 & 0.0005 & & 0.0008 & 0.0008 & 0.0024 & 0.00 & 0.0005 & 03 & 0010 & 0014 & 0.0018 & 0.0010 & 0.0012 & 0.0 & .0005 & 02 & 0.0015 \\
\hline & Opitutae & & 0.0000 & 0.0002 & 0.0002 & 0.0001 & 0.0000 & 0.0001 & 0.0000 & 0.00 & 0.0002 & 0001 & 0.0000 & 0.0000 & 0.0002 & 0.0000 & .0000 & .00000 & 0.0006 \\
\hline \multirow[t]{5}{*}{ Verrucomicrobia } & & 0.0146 & 0.0102 & 0.0090 & 0.0327 & 0.0405 & 0.0361 & 0.03 & 0.0401 & 0.0443 & 0196 & 0.0214 & 0.0270 & 0.0558 & 0.0199 & 0.0519 & 0.0269 & 0.0210 & 0.0364 \\
\hline & & 0.0000 & 0.0000 & 0.0000 & 0.0000 & 0.0000 & 0.0000 & 0.0000 & 0.0000 & 0.0000 & 0000 & 0.0000 & 0.0000 & 0.0002 & 0.0000 & 0.0 & .0000 & 0.0000 & 0.0000 \\
\hline & sp & 0.0029 & 0.0020 & 0.0038 & 0.0013 & 0.0014 & 0.0015 & 0.0004 & 0.0004 & 0.0015 & .0020 & 0.0005 & 0.0008 & 0.0002 & 0.0006 & 0.0001 & 0.0015 & 0.0003 & 0.0008 \\
\hline & in Class Verruco-5 & 0.0000 & 0.0000 & 0.0000 & 0.0002 & 0.0000 & 0.0000 & 0.0000 & 0.0001 & 0.0000 & .0000 & 0.0000 & 0.0000 & 0.0000 & 0.0000 & 0.0000 & 0.0000 & 0.0000 & 0.0000 \\
\hline & Verruco & 0.0096 & 0.0078 & 0.0185 & 0.0039 & 0.0078 & 0.0101 & 0.0051 & 0.0062 & 0.0081 & 0.0169 & 0.0072 & 0.0072 & 0.0078 & 0.0049 & 0.0063 & 0.0082 & 0.0040 & 0.0083 \\
\hline WPS-2 & Unidentified order & 0.0132 & 0.0154 & 0.0414 & 0.0296 & 0.0600 & 0.0399 & 0.0398 & 0.0523 & 0.0332 & 0.0495 & 0.0481 & 0.0381 & 0.0306 & 0.0254 & 0.0310 & 0.0733 & 0.0473 & 0.0544 \\
\hline WS1 & Unidentified order & 0.0000 & 0.0000 & 0.0000 & 0.0000 & 0.0000 & 0.0000 & 0.0000 & 0.0000 & 0.0000 & 0.0000 & 0.0000 & 0.0000 & 0.0001 & 0.0000 & 0.0001 & 0.0000 & 0.0000 & 0.0000 \\
\hline WS3 & Sediment-1 & 0.0002 & 0.0001 & 0.0000 & 0.0000 & 0.0000 & 0.0000 & 0.0006 & 0.0000 & 0.0000 & 0.0000 & 0.0000 & 0.0000 & 0.0000 & 0.0000 & 0.0002 & 0.0000 & 0.0000 & 0.0000 \\
\hline
\end{tabular}




\subsubsection{Supplmementary Table 7.1.5: Family-level Taxonomic Affiliation of Bacterial SSU rRNA amplicon reads (weighted abundance)}

Supplementary Table 5 page 1 of 6: Family-level Taxonomic Affiliation of Bacterial SSU rRNA amplicon reads (weighted abundance)

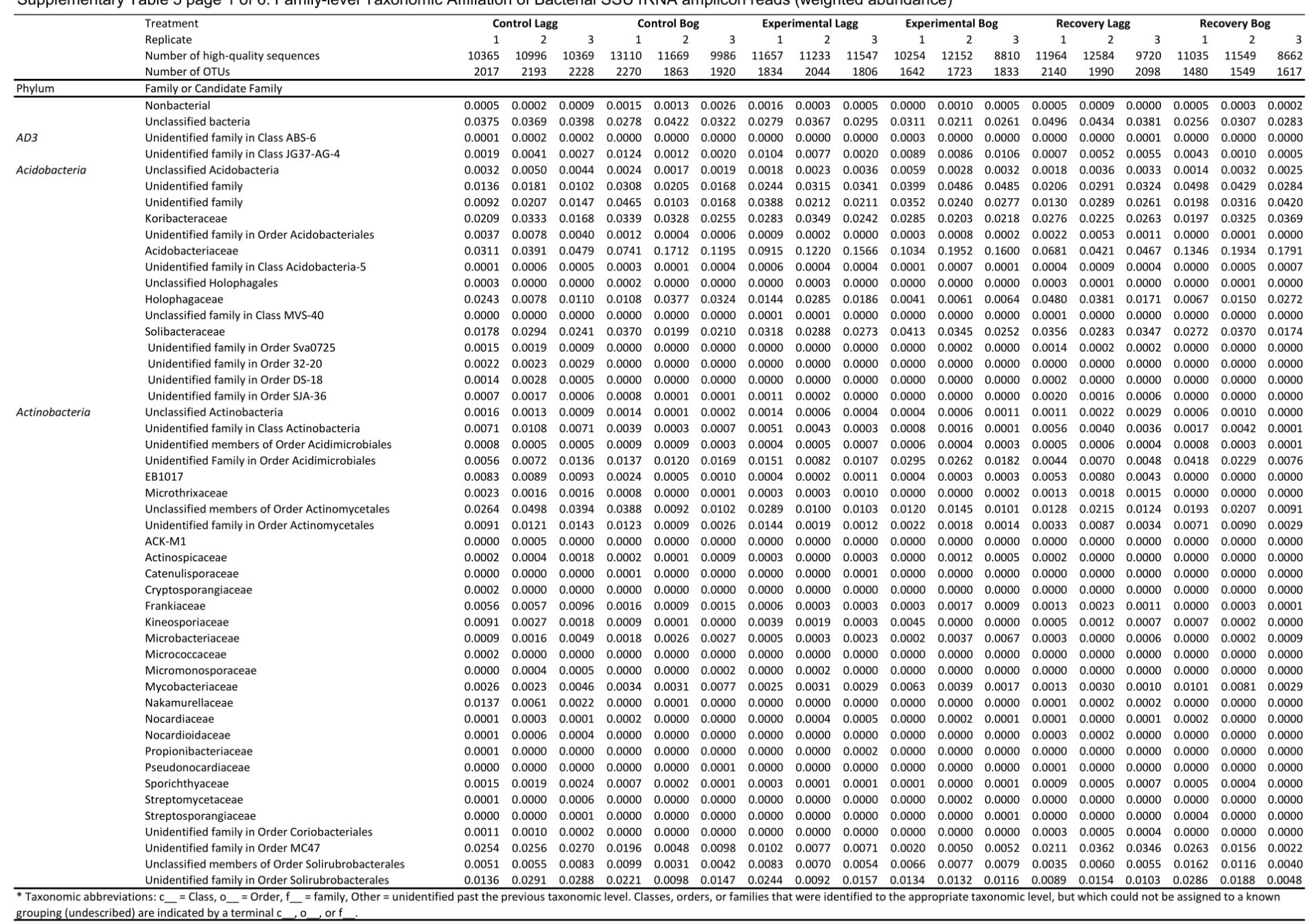


Supplementary Table 5 page 2 of 6: Family-level Taxonomic Affiliation of Bacterial SSU rRNA amplicon reads (weighted abundance)

\begin{tabular}{|c|c|c|c|c|c|c|c|c|c|c|c|c|c|c|c|c|c|c|c|}
\hline & \multirow{2}{*}{$\begin{array}{l}\text { Treatment } \\
\text { Replicate }\end{array}$} & \multicolumn{3}{|c|}{ Control Lagg } & \multicolumn{3}{|c|}{ Control Bog } & \multicolumn{3}{|c|}{ Experimental Lagg } & \multicolumn{3}{|c|}{ Experimental Bog } & \multicolumn{3}{|c|}{ Recovery Lagg } & \multicolumn{3}{|c|}{ Recovery Bog } \\
\hline & & 1 & & 3 & 1 & & 3 & & & 3 & & & 3 & & & 3 & & & 3 \\
\hline & Number of high-quality sequences & 10365 & 10996 & 10369 & 13110 & 11669 & 9986 & 11657 & 11233 & 11547 & 10254 & 12152 & 8810 & 11964 & 12584 & 9720 & 11035 & 11549 & 8662 \\
\hline & Number of OTUs & 2017 & 2193 & 2228 & 2270 & 1863 & 1920 & 1834 & 2044 & 1806 & 1642 & 1723 & 1833 & 2140 & 1990 & 2098 & 1480 & 1549 & 1617 \\
\hline Phylum & \multicolumn{19}{|l|}{ Family or Candidate Family } \\
\hline$\overline{\text { Actinobacteria }}$ & Patulibacteraceae & 0.0020 & 0.0002 & 0.0011 & 0.0000 & 0.0000 & 0.0000 & 0.0001 & 0.0000 & 0.0000 & 0.0000 & 0.0000 & 0.0000 & 0.0008 & 0.0000 & 0.0002 & 0.0000 & 0.0000 & 0.0000 \\
\hline \multirow[t]{7}{*}{ Armatimonadetes } & Unclassified Armatimonadetes & 0.0000 & 0.0001 & 0.0000 & 0.0004 & 0.0000 & 0.0000 & 0.0000 & 0.0000 & 0.0000 & 0.0000 & 0.0000 & 0.0002 & 0.0000 & 0.0000 & 0.0000 & 0.0000 & 0.0000 & 0.0000 \\
\hline & Unclassified members of Order Armatimonadales & 0.0000 & 0.0000 & 0.0000 & 0.0000 & 0.0000 & 0.0000 & 0.0000 & 0.0000 & 0.0002 & 0.0000 & 0.0001 & 0.0002 & 0.0000 & 0.0000 & 0.0000 & 0.0000 & 0.0000 & 0.0000 \\
\hline & Armatimonadaceae & 0.0000 & 0.0000 & 0.0000 & 0.0000 & 0.0000 & 0.0000 & 0.0000 & 0.0000 & 0.0001 & 0.0005 & 0.0002 & 0.0001 & 0.0001 & 0.0000 & 0.0000 & 0.0000 & 0.0000 & 0.0000 \\
\hline & WD294 & 0.0006 & 0.0001 & 0.0016 & 0.0007 & 0.0011 & 0.0003 & 0.0000 & 0.0000 & 0.0008 & 0.0025 & 0.0016 & 0.0024 & 0.0006 & 0.0007 & 0.0001 & 0.0002 & 0.0003 & 0.0007 \\
\hline & Unidentified family in Class $\mathrm{CH} 21$ & 0.0025 & 0.0014 & 0.0028 & 0.0029 & 0.0015 & 0.0018 & 0.0015 & 0.0009 & 0.0031 & 0.0047 & 0.0041 & 0.0034 & 0.0010 & 0.0006 & 0.0005 & 0.0003 & 0.0023 & 0.0002 \\
\hline & Chthonomonadaceae & 0.0011 & 0.0014 & 0.0005 & 0.0009 & 0.0017 & 0.0008 & 0.0000 & 0.0001 & 0.0008 & 0.0026 & 0.0005 & 0.0010 & 0.0004 & 0.0004 & 0.0005 & 0.0001 & 0.0001 & 0.0001 \\
\hline & Unidentified family in Class SJA-176 & 0.0002 & 0.0000 & 0.0000 & 0.0001 & 0.0000 & 0.0002 & 0.0000 & 0.0002 & 0.0000 & 0.0000 & 0.0000 & 0.0000 & 0.0003 & 0.0003 & 0.0005 & 0.0000 & 0.0002 & 0.0000 \\
\hline \multirow[t]{2}{*}{ BRC1 } & Unidentified family & 0.0003 & 0.0002 & 0.0007 & 0.0001 & 0.0003 & 0.0009 & 0.0005 & 0.0002 & 0.0010 & 0.0011 & 0.0005 & 0.0007 & 0.0001 & 0.0000 & 0.0001 & 0.0010 & 0.0003 & 0.0002 \\
\hline & Unidentified family in Class PRR-11 & 0.0004 & 0.0002 & 0.0002 & 0.0000 & 0.0000 & 0.0000 & 0.0000 & 0.0000 & 0.0000 & 0.0000 & 0.0000 & 0.0000 & 0.0000 & 0.0000 & 0.0000 & 0.0000 & 0.0000 & 0.0000 \\
\hline \multirow{10}{*}{ Bacteroidetes } & Unclassified Bacteriodetes & 0.0025 & 0.0036 & 0.0030 & 0.0012 & 0.0022 & 0.0024 & 0.0008 & 0.0021 & 0.0030 & 0.0018 & 0.0028 & 0.0049 & 0.0036 & 0.0014 & 0.0033 & 0.0028 & 0.0023 & 0.0027 \\
\hline & Unidentified family & 0.0000 & 0.0001 & 0.0001 & 0.0001 & 0.0003 & 0.0003 & 0.0001 & 0.0002 & 0.0006 & 0.0001 & 0.0002 & 0.0000 & 0.0000 & 0.0003 & 0.0001 & 0.0000 & 0.0000 & 0.0001 \\
\hline & Unclassified members of Order Bacteroidales & 0.0002 & 0.0000 & 0.0000 & 0.0000 & 0.0000 & 0.0000 & 0.0000 & 0.0000 & 0.0000 & 0.0000 & 0.0000 & 0.0000 & 0.0002 & 0.0000 & 0.0000 & 0.0000 & 0.0000 & 0.0000 \\
\hline & Unidentified family in Order Bacteroidales & 0.0009 & 0.0002 & 0.0000 & 0.0000 & 0.0001 & 0.0000 & 0.0005 & 0.0001 & 0.0000 & 0.0000 & 0.0000 & 0.0000 & 0.0016 & 0.0006 & 0.0007 & 0.0000 & 0.0000 & 0.0000 \\
\hline & Porphyromonadaceae & 0.0001 & 0.0002 & 0.0003 & 0.0000 & 0.0004 & 0.0002 & 0.0000 & 0.0003 & 0.0000 & 0.0000 & 0.0000 & 0.0000 & 0.0003 & 0.0000 & 0.0012 & 0.0000 & 0.0002 & 0.0002 \\
\hline & Flavobacteriaceae & 0.0015 & 0.0008 & 0.0014 & 0.0000 & 0.0000 & 0.0000 & 0.0000 & 0.0007 & 0.0000 & 0.0000 & 0.0000 & 0.0000 & 0.0000 & 0.0000 & 0.0000 & 0.0000 & 0.0000 & 0.0000 \\
\hline & Unclassified Sphingobacteriales & 0.0004 & 0.0001 & 0.0001 & 0.0004 & 0.0002 & 0.0001 & 0.0002 & 0.0001 & 0.0006 & 0.0000 & 0.0003 & 0.0005 & 0.0000 & 0.0002 & 0.0000 & 0.0002 & 0.0001 & 0.0003 \\
\hline & Unidentified family in Order Sphingobacteriales & 0.0049 & 0.0070 & 0.0162 & 0.0047 & 0.0099 & 0.0087 & 0.0020 & 0.0053 & 0.0073 & 0.0030 & 0.0053 & 0.0047 & 0.0054 & 0.0045 & 0.0030 & 0.0014 & 0.0037 & 0.0033 \\
\hline & Flexibacteraceae & 0.0005 & 0.0002 & 0.0008 & 0.0001 & 0.0000 & 0.0001 & 0.0000 & 0.0000 & 0.0000 & 0.0000 & 0.0002 & 0.0006 & 0.0001 & 0.0001 & 0.0000 & 0.0000 & 0.0000 & 0.0000 \\
\hline & Sphingobacteriaceae & 0.0028 & 0.0015 & 0.0046 & 0.0012 & 0.0016 & 0.0011 & 0.0010 & 0.0015 & 0.0017 & 0.0006 & 0.0001 & 0.0006 & 0.0005 & 0.0006 & 0.0010 & 0.0007 & 0.0007 & 0.0012 \\
\hline \multirow[t]{5}{*}{ Chlorobi } & Unidentified family in Class BSV19 & 0.0014 & 0.0004 & 0.0003 & 0.0015 & 0.0007 & 0.0000 & 0.0007 & 0.0010 & 0.0000 & 0.0000 & 0.0000 & 0.0000 & 0.0067 & 0.0042 & 0.0181 & 0.0000 & 0.0000 & 0.0000 \\
\hline & Ignavibacteriaceae & 0.0002 & 0.0002 & 0.0004 & 0.0000 & 0.0000 & 0.0000 & 0.0002 & 0.0008 & 0.0000 & 0.0000 & 0.0000 & 0.0000 & 0.0005 & 0.0002 & 0.0002 & 0.0008 & 0.0000 & 0.0007 \\
\hline & Unidentified family in Class OPB56 & 0.0004 & 0.0002 & 0.0001 & 0.0000 & 0.0000 & 0.0000 & 0.0000 & 0.0000 & 0.0000 & 0.0000 & 0.0000 & 0.0000 & 0.0010 & 0.0007 & 0.0002 & 0.0000 & 0.0000 & 0.0000 \\
\hline & Unidentified family in Class SJA-28 & 0.0004 & 0.0004 & 0.0000 & 0.0000 & 0.0000 & 0.0000 & 0.0000 & 0.0000 & 0.0000 & 0.0000 & 0.0000 & 0.0000 & 0.0000 & 0.0000 & 0.0000 & 0.0000 & 0.0000 & 0.0000 \\
\hline & Unidentified family in Class SM1BO9 & 0.0006 & 0.0029 & 0.0014 & 0.0004 & 0.0004 & 0.0005 & 0.0015 & 0.0015 & 0.0043 & 0.0000 & 0.0010 & 0.0031 & 0.0026 & 0.0014 & 0.0025 & 0.0003 & 0.0018 & 0.0015 \\
\hline Chloroflexi & Unclassified Chloroflexi & 0.0011 & 0.0004 & 0.0003 & 0.0006 & 0.0002 & 0.0001 & 0.0001 & 0.0003 & 0.0001 & 0.0006 & 0.0003 & 0.0005 & 0.0024 & 0.0010 & 0.0055 & 0.0029 & 0.0027 & 0.0000 \\
\hline & Unidentified family & 0.0002 & 0.0003 & 0.0003 & 0.0001 & 0.0000 & 0.0000 & 0.0000 & 0.0000 & 0.0000 & 0.0000 & 0.0000 & 0.0000 & 0.0002 & 0.0001 & 0.0000 & 0.0000 & 0.0000 & 0.0000 \\
\hline & Unclassified members of Class Anaerolineae & 0.0007 & 0.0005 & 0.0000 & 0.0002 & 0.0002 & 0.0000 & 0.0000 & 0.0001 & 0.0000 & 0.0000 & 0.0000 & 0.0000 & 0.0008 & 0.0006 & 0.0012 & 0.0001 & 0.0000 & 0.0000 \\
\hline & S47 & 0.0009 & 0.0003 & 0.0000 & 0.0000 & 0.0000 & 0.0000 & 0.0000 & 0.0000 & 0.0000 & 0.0000 & 0.0000 & 0.0000 & 0.0000 & 0.0000 & 0.0002 & 0.0000 & 0.0000 & 0.0000 \\
\hline & Unidenti & 0.0027 & 0.0027 & 0.0018 & 0.0004 & 0.0000 & 0.0000 & 0.0001 & 0.0000 & 0.0001 & 0.0000 & 0.0000 & 0.0000 & 0.0013 & 0.0014 & 0.0012 & 0.0000 & 0.0000 & 0.0000 \\
\hline & Anaeroli & 0.0003 & 0.0000 & 0.0000 & 0.0000 & 0.0000 & 0.0001 & 0.0000 & 0.0000 & 0.0000 & 0.0000 & 0.0000 & 0.0000 & 0.0001 & 0.0000 & 0.0004 & 0.0000 & 0.0000 & 0.0000 \\
\hline & Unidentified family in Order H39 & 0.0004 & 0.0001 & 0.0002 & 0.0000 & 0.0000 & 0.0000 & 0.0000 & 0.0000 & 0.0000 & 0.0000 & 0.0000 & 0.0000 & 0.0006 & 0.0002 & 0.0002 & 0.0000 & 0.0000 & 0.0000 \\
\hline & Unidentified family in Order SJA-15 & 0.0000 & 0.0000 & 0.0000 & 0.0000 & 0.0000 & 0.0000 & 0.0002 & 0.0000 & 0.0000 & 0.0000 & 0.0000 & 0.0000 & 0.0000 & 0.0000 & 0.0000 & 0.0000 & 0.0000 & 0.0000 \\
\hline & Unidentified family in Order WCHB1-50 & 0.0005 & 0.0001 & 0.0000 & 0.0000 & 0.0000 & 0.0000 & 0.0000 & 0.0000 & 0.0000 & 0.0000 & 0.0000 & 0.0000 & 0.0009 & 0.0005 & 0.0010 & 0.0000 & 0.0000 & 0.0000 \\
\hline & Unidentified family in Order envOPS 12 & 0.0054 & 0.0016 & 0.0005 & 0.0037 & 0.0011 & 0.0029 & 0.0054 & 0.0085 & 0.0025 & 0.0011 & 0.0000 & 0.0000 & 0.0113 & 0.0063 & 0.0216 & 0.0052 & 0.0011 & 0.0000 \\
\hline & 5B-12 & 0.0000 & 0.0002 & 0.0000 & 0.0000 & 0.0000 & 0.0000 & 0.0000 & 0.0000 & 0.0000 & 0.0000 & 0.0000 & 0.0000 & 0.0000 & 0.0000 & 0.0000 & 0.0000 & 0.0000 & 0.0000 \\
\hline & $\mathrm{FFCH} 4570$ & 0.0005 & 0.0005 & 0.0005 & 0.0000 & 0.0000 & 0.0000 & 0.0004 & 0.0000 & 0.0000 & 0.0000 & 0.0000 & 0.0000 & 0.0000 & 0.0001 & 0.0001 & 0.0000 & 0.0000 & 0.0000 \\
\hline & Dehalococcoidaceae & 0.0001 & 0.0001 & 0.0000 & 0.0000 & 0.0000 & 0.0000 & 0.0000 & 0.0000 & 0.0000 & 0.0000 & 0.0000 & 0.0000 & 0.0003 & 0.0000 & 0.0001 & 0.0000 & 0.0000 & 0.0000 \\
\hline & Unidentified family in Class Ktedonobacteria & 0.0032 & 0.0043 & 0.0078 & 0.0022 & 0.0082 & 0.0045 & 0.0003 & 0.0016 & 0.0033 & 0.0077 & 0.0055 & 0.0089 & 0.0067 & 0.0043 & 0.0009 & 0.0009 & 0.0034 & 0.0009 \\
\hline & Unident & 0.0000 & 0.0000 & 0.0000 & 0.0000 & 0.0000 & 0.0000 & 0.0000 & 0.0000 & 0.0000 & 0.0000 & 0.0000 & 0.0000 & 0.0000 & 0.0001 & 0.0003 & 0.0000 & 0.0000 & 0.0000 \\
\hline & OGA31 & 0.0078 & 0.0042 & 0.0049 & 0.0014 & 0.0002 & 0.0005 & 0.0009 & 0.0015 & 0.0000 & 0.0001 & 0.0001 & 0.0001 & 0.0055 & 0.0030 & 0.0077 & 0.0000 & 0.0000 & 0.0000 \\
\hline & Unidentified family in Class $\mathrm{TI}$ & 0.0000 & 0.0002 & 0.0000 & 0.0000 & 0.0000 & 0.0000 & 0.0000 & 0.0000 & 0.0000 & 0.0000 & 0.0000 & 0.0000 & 0.0000 & 0.0000 & 0.0000 & 0.0000 & 0.0000 & 0.0000 \\
\hline & Unidentified family in Order 5085 & 0.0009 & 0.0008 & 0.0002 & 0.0000 & 0.0000 & 0.0000 & 0.0000 & 0.0000 & 0.0000 & 0.0000 & 0.0000 & 0.0000 & 0.0000 & 0.0004 & 0.0000 & 0.0000 & 0.0000 & 0.0000 \\
\hline Cyanobacteria & Unclassified Cyanobacteria & 0.0002 & 0.0011 & 0.0004 & 0.0091 & 0.0090 & 0.0081 & 0.0004 & 0.0004 & 0.0004 & 0.0051 & 0.0058 & 0.0027 & 0.0003 & 0.0002 & 0.0001 & 0.0019 & 0.0042 & 0.0009 \\
\hline & class $4 \mathrm{COd}-2$ & 0.0001 & 0.0000 & 0.0002 & 0.0002 & 0.0000 & 0.0003 & 0.0000 & 0.0000 & 0.0000 & 0.0000 & 0.0000 & 0.0000 & 0.0003 & 0.0006 & 0.0003 & 0.0000 & 0.0000 & 0.0000 \\
\hline & & 0.0000 & 0.0000 & 0.0000 & 0.0000 & 0.0000 & 0.0003 & 0.0000 & 0.0000 & 0.0000 & 0.0004 & 0.0002 & 0.0000 & 0.0000 & 0.0011 & 0.0000 & 0.0000 & 0.0000 & 0.0000 \\
\hline & Unidentified family in Order SM1D11 & 0.0004 & 0.0001 & 0.0003 & 0.0002 & 0.0004 & 0.0007 & 0.0000 & 0.0000 & 0.0001 & 0.0002 & 0.0000 & 0.0000 & 0.0000 & 0.0008 & 0.0001 & 0.0001 & 0.0001 & 0.0005 \\
\hline & Unidentified family in Order mle1-12 & 0.0020 & 0.0013 & 0.0014 & 0.0020 & 0.0028 & 0.0028 & 0.0012 & 0.0036 & 0.0014 & 0.0017 & 0.0011 & 0.0020 & 0.0009 & 0.0003 & 0.0007 & 0.0013 & 0.0041 & 0.0024 \\
\hline & Chloroplast & 0.0000 & 0.0000 & 0.0003 & 0.0000 & 0.0005 & 0.0002 & 0.0004 & 0.0001 & 0.0003 & 0.0000 & 0.0000 & 0.0000 & 0.0000 & 0.0000 & 0.0000 & 0.0000 & 0.0000 & 0.0000 \\
\hline
\end{tabular}


Supplementary Table 5 page 3 of 6: Family-level Taxonomic Affiliation of Bacterial SSU rRNA amplicon reads (weighted abundance)

\begin{tabular}{|c|c|c|c|c|c|c|c|c|c|c|c|c|c|c|c|c|c|c|c|}
\hline & \multirow{2}{*}{$\begin{array}{l}\text { Treatment } \\
\text { Replicate }\end{array}$} & \multicolumn{3}{|c|}{ Control Lagg } & \multicolumn{3}{|c|}{ Control Bog } & \multicolumn{3}{|c|}{ Experimental Lagg } & \multicolumn{3}{|c|}{ Experimental Bog } & \multicolumn{3}{|c|}{ Recovery Lagg } & \multicolumn{3}{|c|}{ Recovery Bog } \\
\hline & & 1 & & 3 & 1 & & 3 & & & 3 & & & 3 & & & 3 & & & \\
\hline & Number of high-quality sequences & 10365 & 10996 & 10369 & 13110 & 11669 & 9986 & 11657 & 11233 & 11547 & 10254 & 12152 & 8810 & 11964 & 12584 & 9720 & 11035 & 11549 & 8662 \\
\hline & Number of OTUs & 2017 & 2193 & 2228 & 2270 & 1863 & 1920 & 1834 & 2044 & 1806 & 1642 & 1723 & 1833 & 2140 & 1990 & 2098 & 1480 & 1549 & 1617 \\
\hline Phylum & Family or Candidate Family & & & & & & & & & & & & & & & & & & \\
\hline \multirow{10}{*}{ Cyanobacteria } & Chloroplast: Chlorphyta & 0.0000 & 0.0000 & 0.0002 & 0.0000 & 0.0001 & 0.0002 & 0.0000 & 0.0005 & 0.0002 & 0.0000 & 0.0000 & 0.0000 & 0.0000 & 0.0000 & 0.0000 & 0.0003 & 0.0000 & 0.0003 \\
\hline & Chloroplast: Chlamydomonadaceae & 0.0009 & 0.0007 & 0.0007 & 0.0000 & 0.0010 & 0.0004 & 0.0000 & 0.0003 & 0.0005 & 0.0000 & 0.0000 & 0.0002 & 0.0002 & 0.0000 & 0.0001 & 0.0006 & 0.0006 & 0.0012 \\
\hline & Chloroplast: Trebouxiophyceae & 0.0002 & 0.0000 & 0.0000 & 0.0000 & 0.0001 & 0.0002 & 0.0000 & 0.0000 & 0.0000 & 0.0001 & 0.0000 & 0.0000 & 0.0002 & 0.0000 & 0.0000 & 0.0000 & 0.0000 & 0.0009 \\
\hline & Chloroplast: Unidentified family in Class Cryptophyta & 0.0000 & 0.0000 & 0.0000 & 0.0000 & 0.0000 & 0.0000 & 0.0000 & 0.0001 & 0.0001 & 0.0000 & 0.0000 & 0.0001 & 0.0000 & 0.0000 & 0.0000 & 0.0000 & 0.0003 & 0.0000 \\
\hline & Chloroplast: Unidentified family in Class Euglenozoa & 0.0000 & 0.0000 & 0.0000 & 0.0000 & 0.0000 & 0.0001 & 0.0000 & 0.0000 & 0.0001 & 0.0000 & 0.0000 & 0.0000 & 0.0001 & 0.0000 & 0.0000 & 0.0004 & 0.0000 & 0.0006 \\
\hline & Chloroplast: Unidentified family in Class Stramenopiles & 0.0026 & 0.0024 & 0.0068 & 0.0005 & 0.0032 & 0.0096 & 0.0020 & 0.0069 & 0.0049 & 0.0000 & 0.0000 & 0.0002 & 0.0009 & 0.0004 & 0.0027 & 0.0013 & 0.0003 & 0.0038 \\
\hline & Chloroplast: Unidentified family in Class Streptophyta & 0.0039 & 0.0010 & 0.0098 & 0.0105 & 0.0147 & 0.0210 & 0.0098 & 0.0023 & 0.0003 & 0.0128 & 0.0148 & 0.0106 & 0.0006 & 0.0001 & 0.0092 & 0.0058 & 0.0218 & 0.0455 \\
\hline & Nostocaceae & 0.0000 & 0.0000 & 0.0000 & 0.0000 & 0.0000 & 0.0000 & 0.0001 & 0.0003 & 0.0000 & 0.0000 & 0.0000 & 0.0000 & 0.0003 & 0.0002 & 0.0000 & 0.0000 & 0.0021 & 0.0069 \\
\hline & Phormidiaceae & 0.0000 & 0.0000 & 0.0000 & 0.0000 & 0.0000 & 0.0000 & 0.0000 & 0.0000 & 0.0000 & 0.0000 & 0.0000 & 0.0000 & 0.0000 & 0.0002 & 0.0000 & 0.0000 & 0.0000 & 0.0000 \\
\hline & Unidentified family in Class S15B-MN24 & 0.0003 & 0.0001 & 0.0001 & 0.0000 & 0.0000 & 0.0000 & 0.0000 & 0.0002 & 0.0000 & 0.0002 & 0.0000 & 0.0001 & 0.0000 & 0.0001 & 0.0001 & 0.0004 & 0.0003 & 0.0000 \\
\hline \multirow[t]{3}{*}{ Elusimicrobia } & Unidentified family in Order Elusimicrobiales & 0.0008 & 0.0001 & 0.0004 & 0.0002 & 0.0006 & 0.0006 & 0.0003 & 0.0003 & 0.0006 & 0.0010 & 0.0004 & 0.0008 & 0.0004 & 0.0012 & 0.0002 & 0.0002 & 0.0002 & 0.0001 \\
\hline & Unidentified family in Order FAC88 & 0.0030 & 0.0042 & 0.0025 & 0.0026 & 0.0028 & 0.0009 & 0.0034 & 0.0049 & 0.0044 & 0.0016 & 0.0010 & 0.0035 & 0.0038 & 0.0040 & 0.0069 & 0.0014 & 0.0004 & 0.0020 \\
\hline & Unidentified family & 0.0003 & 0.0000 & 0.0005 & 0.0000 & 0.0000 & 0.0000 & 0.0004 & 0.0000 & 0.0000 & 0.0000 & 0.0000 & 0.0000 & 0.0000 & 0.0003 & 0.0004 & 0.0000 & 0.0000 & 0.0000 \\
\hline \multirow[t]{15}{*}{ Firmicutes } & Unclassified Firmicutes & 0.0000 & 0.0001 & 0.0000 & 0.0000 & 0.0000 & 0.0000 & 0.0000 & 0.0000 & 0.0000 & 0.0000 & 0.0000 & 0.0001 & 0.0000 & 0.0000 & 0.0000 & 0.0006 & 0.0000 & 0.0003 \\
\hline & Unclassified members of Class Bacilli & 0.0000 & 0.0000 & 0.0000 & 0.0000 & 0.0000 & 0.0000 & 0.0000 & 0.0000 & 0.0000 & 0.0005 & 0.0000 & 0.0000 & 0.0000 & 0.0000 & 0.0000 & 0.0000 & 0.0000 & 0.0000 \\
\hline & Unclassified members of Order Bacillales & 0.0001 & 0.0001 & 0.0000 & 0.0000 & 0.0000 & 0.0000 & 0.0000 & 0.0000 & 0.0000 & 0.0000 & 0.0001 & 0.0001 & 0.0000 & 0.0000 & 0.0000 & 0.0000 & 0.0000 & 0.0000 \\
\hline & Alicyclobacillaceae & 0.0001 & 0.0000 & 0.0000 & 0.0000 & 0.0000 & 0.0000 & 0.0002 & 0.0001 & 0.0001 & 0.0000 & 0.0005 & 0.0001 & 0.0000 & 0.0000 & 0.0000 & 0.0000 & 0.0000 & 0.0000 \\
\hline & Bacillaceae & 0.0004 & 0.0004 & 0.0003 & 0.0009 & 0.0003 & 0.0002 & 0.0000 & 0.0001 & 0.0004 & 0.0003 & 0.0013 & 0.0009 & 0.0001 & 0.0002 & 0.0001 & 0.0004 & 0.0007 & 0.0001 \\
\hline & Paenibacillaceae & 0.0010 & 0.0005 & 0.0001 & 0.0014 & 0.0036 & 0.0048 & 0.0024 & 0.0026 & 0.0027 & 0.0021 & 0.0044 & 0.0031 & 0.0005 & 0.0009 & 0.0015 & 0.0056 & 0.0048 & 0.0020 \\
\hline & Planococcaceae & 0.0011 & 0.0004 & 0.0001 & 0.0000 & 0.0000 & 0.0002 & 0.0000 & 0.0000 & 0.0000 & 0.0008 & 0.0004 & 0.0018 & 0.0003 & 0.0000 & 0.0000 & 0.0000 & 0.0000 & 0.0000 \\
\hline & Unclassified Clostridia & 0.0000 & 0.0000 & 0.0000 & 0.0000 & 0.0000 & 0.0000 & 0.0000 & 0.0000 & 0.0000 & 0.0000 & 0.0000 & 0.0000 & 0.0000 & 0.0002 & 0.0000 & 0.0000 & 0.0000 & 0.0000 \\
\hline & ers of Order Clostridiales & 0.0000 & 0.0000 & 0.0000 & 0.0000 & 0.0000 & 0.0002 & 0.0000 & 0.0000 & 0.0000 & 0.0000 & 0.0004 & 0.0002 & 0.0000 & 0.0000 & 0.0000 & 0.0000 & 0.0000 & 0.0000 \\
\hline & Clostridiaceae & 0.0018 & 0.0016 & 0.0015 & 0.0014 & 0.0015 & 0.0004 & 0.0004 & 0.0023 & 0.0002 & 0.0015 & 0.0016 & 0.0012 & 0.0005 & 0.0009 & 0.0035 & 0.0020 & 0.0017 & 0.0014 \\
\hline & Lachnospiraceae & 0.0000 & 0.0003 & 0.0000 & 0.0002 & 0.0000 & 0.0000 & 0.0000 & 0.0000 & 0.0000 & 0.0000 & 0.0000 & 0.0001 & 0.0000 & 0.0000 & 0.0000 & 0.0000 & 0.0000 & 0.0000 \\
\hline & Peptococcaceae & 0.0006 & 0.0004 & 0.0008 & 0.0001 & 0.0001 & 0.0003 & 0.0001 & 0.0004 & 0.0001 & 0.0013 & 0.0002 & 0.0012 & 0.0001 & 0.0001 & 0.0005 & 0.0001 & 0.0003 & 0.0001 \\
\hline & Ruminococcaceae & 0.0000 & 0.0000 & 0.0000 & 0.0001 & 0.0000 & 0.0000 & 0.0000 & 0.0000 & 0.0000 & 0.0002 & 0.0000 & 0.0000 & 0.0001 & 0.0004 & 0.0000 & 0.0000 & 0.0005 & 0.0000 \\
\hline & & 0003 & 0.0005 & 0.0007 & 0.0002 & 0.0016 & 0.0022 & 0.0007 & 0.0030 & 0.0000 & 0.0057 & 0.0099 & 0.0008 & 0.0020 & 0.0006 & 0.0014 & 0.0034 & 0.0016 & 0.0018 \\
\hline & Unidentified family in Order OPB54 & 0.0000 & 0.0000 & 0.0000 & 0.0000 & 0.0000 & 0.0000 & 0.0000 & 0.0000 & 0.0000 & 0.0003 & 0.0000 & 0.0000 & 0.0000 & 0.0000 & 0.0000 & 0.0000 & 0.0000 & 0.0000 \\
\hline \multirow[t]{3}{*}{ Gemmatimonadetes } & Unclassified Gemmatimonadales & 0.0000 & 0.0000 & 0.0000 & 0.0000 & 0.0000 & 0.0000 & 0.0000 & 0.0002 & 0.0000 & 0.0000 & 0.0000 & 0.0000 & 0.0000 & 0.0000 & 0.0000 & 0.0000 & 0.0000 & 0.0000 \\
\hline & Unidentified family in Order Gemmatimonadales & 0.0011 & 0.0004 & 0.0007 & 0.0004 & 0.0007 & 0.0002 & 0.0014 & 0.0011 & 0.0025 & 0.0000 & 0.0000 & 0.0000 & 0.0004 & 0.0003 & 0.0004 & 0.0000 & 0.0000 & 0.0000 \\
\hline & Gemmati & 0.0028 & 0.0019 & 0.0004 & 0.0007 & 0.0003 & 0.0004 & 0.0010 & 0.0004 & 0.0015 & 0.0002 & 0.0009 & 0.0009 & 0.0011 & 0.0010 & 0.0005 & 0.0004 & 0.0008 & 0.0007 \\
\hline Lentisphaerae & Unidentified family & 0.0000 & 0.0000 & 0.0000 & 0.0000 & 0.0000 & 0.0000 & 0.0000 & 0.0000 & 0.0000 & 0.0000 & 0.0002 & 0.0000 & 0.0000 & 0.0000 & 0.0000 & 0.0000 & 0.0000 & 0.0000 \\
\hline & Unidentified family in Order JH-WHS47 & 0.0001 & 0.0000 & 0.0000 & 0.0001 & 0.0000 & 0.0000 & 0.0002 & 0.0001 & 0.0000 & 0.0000 & 0.0000 & 0.0000 & 0.0000 & 0.0004 & 0.0003 & 0.0000 & 0.0000 & 0.0000 \\
\hline \multirow[t]{3}{*}{ Nitrospirae } & FW (Family) & 0.0000 & 0.0000 & 0.0000 & 0.0000 & 0.0000 & 0.0000 & 0.0000 & 0.0000 & 0.0000 & 0.0000 & 0.0000 & 0.0000 & 0.0002 & 0.0000 & 0.0000 & 0.0000 & 0.0000 & 0.0000 \\
\hline & Nitrospiraceae & 0.0001 & 0.0009 & 0.0000 & 0.0000 & 0.0000 & 0.0000 & 0.0000 & 0.0000 & 0.0000 & 0.0000 & 0.0000 & 0.0000 & 0.0002 & 0.0016 & 0.0005 & 0.0000 & 0.0000 & 0.0000 \\
\hline & Thermodesulfovibrionaceae & 0.0024 & 0.0013 & 0.0003 & 0.0002 & 0.0000 & 0.0002 & 0.0003 & 0.0002 & 0.0000 & 0.0000 & 0.0000 & 0.0003 & 0.0007 & 0.0001 & 0.0012 & 0.0001 & 0.0001 & 0.0001 \\
\hline OP3 & kpj58rc & 0.0023 & 0.0009 & 0.0013 & 0.0006 & 0.0011 & 0.0024 & 0.0017 & 0.0022 & 0.0028 & 0.0019 & 0.0020 & 0.0043 & 0.0017 & 0.0007 & 0.0020 & 0.0003 & 0.0010 & 0.0017 \\
\hline Planctomycetes & classified Planctomycetes & 0.0000 & 0.0000 & 0.0000 & 0.0001 & 0.0000 & 0.0000 & 0.0000 & 0.0000 & 0.0000 & 0.0000 & 0.0001 & 0.0000 & 0.0000 & 0.0000 & 0.0000 & 0.0000 & 0.0000 & 0.0000 \\
\hline & Unidentified family & 0.0001 & 0.0006 & 0.0003 & 0.0006 & 0.0000 & 0.0005 & 0.0000 & 0.0000 & 0.0001 & 0.0005 & 0.0002 & 0.0000 & 0.0002 & 0.0000 & 0.0000 & 0.0000 & 0.0001 & 0.0000 \\
\hline & Unclassified members of Class Phycisphaerae & 0.0000 & 0.0000 & 0.0000 & 0.0000 & 0.0000 & 0.0000 & 0.0000 & 0.0001 & 0.0000 & 0.0000 & 0.0000 & 0.0000 & 0.0000 & 0.0000 & 0.0001 & 0.0000 & 0.0000 & 0.0000 \\
\hline & u & 0.0021 & 0.0018 & 0.0015 & 0.0031 & 0.0027 & 0.0032 & 0.0024 & 0.0018 & 0.0028 & 0.0038 & 0.0016 & 0.0065 & 0.0008 & 0.0010 & 0.0016 & 0.0013 & 0.0021 & 0.0021 \\
\hline & u & 0.0003 & 0.0005 & 0.0001 & 0.0002 & 0.0002 & 0.0000 & 0.0002 & 0.0001 & 0.0009 & 0.0002 & 0.0002 & 0.0007 & 0.0002 & 0.0005 & 0.0000 & 0.0000 & 0.0007 & 0.0001 \\
\hline & Phycisphaeraceae & 0.0001 & 0.0001 & 0.0000 & 0.0002 & 0.0000 & 0.0001 & 0.0000 & 0.0000 & 0.0000 & 0.0000 & 0.0000 & 0.0007 & 0.0000 & 0.0000 & 0.0001 & 0.0000 & 0.0000 & 0.0000 \\
\hline & Gemmataceae & 0.0063 & 0.0025 & 0.0024 & 0.0051 & 0.0066 & 0.0043 & 0.0057 & 0.0030 & 0.0032 & 0.0108 & 0.0040 & 0.0053 & 0.0046 & 0.0068 & 0.0020 & 0.0041 & 0.0044 & 0.0048 \\
\hline & sphaeraceae & 0.0072 & 0.0064 & 0.0071 & 0.0098 & 0.0094 & 0.0098 & 0.0063 & 0.0022 & 0.0037 & 0.0129 & 0.0053 & 0.0073 & 0.0033 & 0.0106 & 0.0037 & 0.0111 & 0.0108 & 0.0054 \\
\hline & & 0.0009 & 0.0010 & 0.0004 & 0.0005 & 0.0005 & 0.0011 & 0.0019 & 0.0008 & 0.0018 & 0.0009 & 0.0007 & 0.0007 & 0.0013 & 0.0017 & 0.0012 & 0.0015 & 0.0010 & 0.0008 \\
\hline & Un & 0.0017 & 0.0013 & 0.0008 & 0.0014 & 0.0018 & 0.0017 & 0.0011 & 0.0015 & 0.0027 & 0.0011 & 0.0011 & 0.0015 & 0.0011 & 0.0017 & 0.0005 & 0.0010 & 0.0019 & 0.00 \\
\hline & Pirellulaceae & 0.0041 & 0.0028 & 0.0036 & 0.0050 & 0.0033 & 0.0036 & 0.0062 & 0.0036 & 0.0042 & 0.0021 & 0.0027 & 0.0042 & 0.0035 & 0.0060 & 0.0045 & 0.0043 & 0.0027 & 0.0027 \\
\hline & Planctomycetaceae & 0.0022 & 0.0016 & 0.0018 & 0.0028 & 0.0018 & 0.0024 & 0.0030 & 0.0020 & 0.0023 & 0.0026 & 0.0036 & 0.0024 & 0.0037 & 0.0037 & 0.0014 & 0.0028 & 0.0040 & 0.0013 \\
\hline
\end{tabular}


Supplementary Table 5 page 4 of 6: Family-level Taxonomic Affiliation of Bacterial SSU rRNA amplicon reads (weighted abundance)

\begin{tabular}{|c|c|c|c|c|c|c|c|c|c|c|c|c|c|c|c|c|c|c|c|}
\hline & \multirow{2}{*}{$\begin{array}{l}\text { Treatment } \\
\text { Replicate }\end{array}$} & \multicolumn{3}{|c|}{ Control Lagg } & \multicolumn{3}{|c|}{ Control Bog } & \multicolumn{3}{|c|}{ Experimental Lagg } & \multicolumn{3}{|c|}{ Experimental Bog } & \multicolumn{3}{|c|}{ Recovery Lagg } & \multicolumn{3}{|c|}{ Recovery Bog } \\
\hline & & 1 & 2 & 3 & 1 & 2 & 3 & 1 & 2 & 3 & 1 & 2 & 3 & 1 & 2 & 3 & 1 & 2 & \\
\hline & Number of high-quality sequences & 10365 & 10996 & 10369 & 13110 & 11669 & 9986 & 11657 & 11233 & 11547 & 10254 & 12152 & 8810 & 11964 & 12584 & 9720 & 11035 & 11549 & 8662 \\
\hline & Number of OTUs & 2017 & 2193 & 2228 & 2270 & 1863 & 1920 & 1834 & 2044 & 1806 & 1642 & 1723 & 1833 & 2140 & 1990 & 2098 & 1480 & 1549 & 1617 \\
\hline Phylum & Family or Candidate Family & & & & & & & & & & & & & & & & & & \\
\hline Planctomycetes & Unidentified family in Class vadinHA49 & 0.0001 & 0.0001 & 0.0000 & 0.0000 & 0.0000 & 0.0000 & 0.0000 & 0.0000 & 0.0000 & 0.0000 & 0.0000 & 0.0000 & 0.0000 & 0.0000 & 0.0000 & 0.0000 & 0.0000 & 0.0000 \\
\hline Proteobacteria & Unclassified Proteobacteria & 0.0027 & 0.0047 & 0.0074 & 0.0050 & 0.0050 & 0.0119 & 0.0061 & 0.0063 & 0.0036 & 0.0049 & 0.0086 & 0.0066 & 0.0022 & 0.0043 & 0.0055 & 0.0032 & 0.0048 & 0.0066 \\
\hline \multirow[t]{19}{*}{ Alphaproteobacteria } & Unclassified Alphaproteobacteria & 0.0068 & 0.0076 & 0.0077 & 0.0056 & 0.0056 & 0.0071 & 0.0072 & 0.0065 & 0.0101 & 0.0090 & 0.0088 & 0.0092 & 0.0074 & 0.0070 & 0.0096 & 0.0064 & 0.0039 & 0.0083 \\
\hline & Unidentified family & 0.0110 & 0.0093 & 0.0138 & 0.0094 & 0.0106 & 0.0113 & 0.0086 & 0.0094 & 0.0097 & 0.0107 & 0.0088 & 0.0091 & 0.0127 & 0.0119 & 0.0139 & 0.0053 & 0.0074 & 0.0084 \\
\hline & $\begin{array}{l}\text { Caulobacteraceae } \\
\text { Con }\end{array}$ & 0.0134 & 0.0159 & 0.0180 & 0.0151 & 0.0154 & 0.0155 & 0.0244 & 0.0272 & 0.0158 & 0.0174 & 0.0155 & 0.0106 & 0.0158 & 0.0149 & 0.0143 & 0.0147 & 0.0157 & 0.0110 \\
\hline & Unclassified members of Order Rhizobiales & 0.0893 & 0.0603 & 0.0402 & 0.0387 & 0.0329 & 0.0365 & 0.0374 & 0.0421 & 0.0204 & 0.0279 & 0.0208 & 0.0325 & 0.0380 & 0.0368 & 0.0478 & 0.0213 & 0.0168 & 0.0271 \\
\hline & Unidentified family in Order Rhizobiales & 0.0236 & 0.0397 & 0.0346 & 0.0500 & 0.0346 & 0.0431 & 0.0374 & 0.0300 & 0.0365 & 0.0453 & 0.0333 & 0.0598 & 0.0252 & 0.0243 & 0.0355 & 0.0392 & 0.0302 & 0.0506 \\
\hline & Beijerinckiaceae & 0.0020 & 0.0058 & 0.0025 & 0.0080 & 0.0014 & 0.0036 & 0.0058 & 0.0053 & 0.0009 & 0.0038 & 0.0019 & 0.0032 & 0.0039 & 0.0051 & 0.0025 & 0.0033 & 0.0048 & 0.0013 \\
\hline & Bradyrhizobiaceae & 0.1151 & 0.0622 & 0.0760 & 0.0749 & 0.0728 & 0.0563 & 0.0456 & 0.0627 & 0.0779 & 0.0317 & 0.0268 & 0.0278 & 0.0919 & 0.1053 & 0.0496 & 0.0316 & 0.0282 & 0.0380 \\
\hline & Hyphomicrobiaceae & 0.0566 & 0.0688 & 0.0495 & 0.0420 & 0.0148 & 0.0284 & 0.0411 & 0.0281 & 0.0204 & 0.0283 & 0.0203 & 0.0313 & 0.0378 & 0.0599 & 0.0602 & 0.0242 & 0.0175 & 0.0329 \\
\hline & Methylobacteriaceae & 0.0000 & 0.0000 & 0.0001 & 0.0002 & 0.0000 & 0.0006 & 0.0004 & 0.0002 & 0.0004 & 0.0000 & 0.0000 & 0.0000 & 0.0000 & 0.0000 & 0.0000 & 0.0001 & 0.0002 & 0.0001 \\
\hline & Methylocystaceae & 0.0072 & 0.0137 & 0.0104 & 0.0173 & 0.0022 & 0.0150 & 0.0283 & 0.0267 & 0.0033 & 0.0184 & 0.0226 & 0.0102 & 0.0128 & 0.0124 & 0.0060 & 0.0195 & 0.0223 & 0.0023 \\
\hline & Phyllobacteriaceae & 0.0000 & 0.0000 & 0.0000 & 0.0000 & 0.0000 & 0.0000 & 0.0001 & 0.0002 & 0.0007 & 0.0000 & 0.0000 & 0.0000 & 0.0003 & 0.0014 & 0.0001 & 0.0000 & 0.0000 & 0.0000 \\
\hline & Rhizobiaceae & 0.0000 & 0.0002 & 0.0002 & 0.0000 & 0.0000 & 0.0003 & 0.0000 & 0.0000 & 0.0000 & 0.0000 & 0.0000 & 0.0000 & 0.0003 & 0.0000 & 0.0000 & 0.0000 & 0.0000 & 0.0001 \\
\hline & Xanthobacteraceae & 0.0000 & 0.0001 & 0.0004 & 0.0000 & 0.0003 & 0.0002 & 0.0001 & 0.0001 & 0.0000 & 0.0000 & 0.0000 & 0.0000 & 0.0000 & 0.0000 & 0.0000 & 0.0000 & 0.0000 & 0.0000 \\
\hline & Order Rhdosn & 0.0000 & 0.0000 & 0.0001 & 0.0000 & 0.0000 & 0.0000 & 0.0000 & 0.0000 & 0.0002 & 0.0002 & 0.0000 & 0.0000 & 0.0001 & 0.0000 & 0.0001 & 0.0000 & 0.0000 & 0.0000 \\
\hline & Acetobacteraceae & 0.0372 & 0.0425 & 0.0443 & 0.0333 & 0.0692 & 0.0635 & 0.0529 & 0.0662 & 0.0753 & 0.0748 & 0.0606 & 0.0523 & 0.0367 & 0.0449 & 0.0413 & 0.0692 & 0.0592 & 0.0944 \\
\hline & Rhodospirillaceae & 0.0327 & 0.0309 & 0.0192 & 0.0168 & 0.0155 & 0.0188 & 0.0159 & 0.0160 & 0.0232 & 0.0232 & 0.0116 & 0.0119 & 0.0238 & 0.0244 & 0.0147 & 0.0102 & 0.0075 & 0.0134 \\
\hline & Rickettsiaceae & 0.0000 & 0.0000 & 0.0001 & 0.0002 & 0.0003 & 0.0000 & 0.0000 & 0.0000 & 0.0000 & 0.0001 & 0.0000 & 0.0000 & 0.0001 & 0.0000 & 0.0000 & 0.0000 & 0.0000 & 0.0000 \\
\hline & Unclassified members of Order Sphingomonadales & 0.0000 & 0.0006 & 0.0005 & 0.0000 & 0.0000 & 0.0004 & 0.0003 & 0.0000 & 0.0000 & 0.0000 & 0.0000 & 0.0000 & 0.0004 & 0.0000 & 0.0000 & 0.0000 & 0.0000 & 0.0000 \\
\hline & Sphingomonadaceae & 0.0006 & 0.0007 & 0.0014 & 0.0003 & 0.0002 & 0.0034 & 0.0000 & 0.0010 & 0.0009 & 0.0002 & 0.0001 & 0.0002 & 0.0001 & 0.0000 & 0.0004 & 0.0010 & 0.0009 & 0.0024 \\
\hline \multirow{13}{*}{ Betaproteobacteria } & Unclassified Betaproteobacteria & 0.0024 & 0.0027 & 0.0062 & 0.0045 & 0.0021 & 0.0048 & 0.0054 & 0.0028 & 0.0046 & 0.0043 & 0.0020 & 0.0034 & 0.0054 & 0.0075 & 0.0033 & 0.0010 & 0.0011 & 0.0013 \\
\hline & Unidentified family & 0.0175 & 0.0174 & 0.0102 & 0.0037 & 0.0016 & 0.0019 & 0.0029 & 0.0037 & 0.0049 & 0.0003 & 0.0002 & 0.0002 & 0.0059 & 0.0084 & 0.0069 & 0.0007 & 0.0001 & 0.0009 \\
\hline & Unclassified members of Order Burkholderiales & 0.0005 & 0.0019 & 0.0022 & 0.0002 & 0.0000 & 0.0002 & 0.0003 & 0.0004 & 0.0003 & 0.0061 & 0.0032 & 0.0009 & 0.0012 & 0.0003 & 0.0026 & 0.0000 & 0.0000 & 0.0000 \\
\hline & Unidentified family in Order Burkholderiales & 0.0040 & 0.0025 & 0.0054 & 0.0024 & 0.0021 & 0.0039 & 0.0078 & 0.0036 & 0.0071 & 0.0000 & 0.0011 & 0.0001 & 0.0018 & 0.0020 & 0.0008 & 0.0000 & 0.0010 & 0.0006 \\
\hline & Burkholderiaceae & 0.0019 & 0.0023 & 0.0021 & 0.0011 & 0.0045 & 0.0051 & 0.0007 & 0.0024 & 0.0036 & 0.0010 & 0.0039 & 0.0083 & 0.0007 & 0.0008 & 0.0007 & 0.0017 & 0.0021 & 0.0016 \\
\hline & Comamonadaceae & 0.0015 & 0.0025 & 0.0015 & 0.0001 & 0.0001 & 0.0001 & 0.0002 & 0.0013 & 0.0006 & 0.0000 & 0.0002 & 0.0006 & 0.0013 & 0.0006 & 0.0006 & 0.0000 & 0.0000 & 0.0001 \\
\hline & Oxalobacteraceae & 0.0013 & 0.0035 & 0.0020 & 0.0013 & 0.0010 & 0.0035 & 0.0018 & 0.0027 & 0.0035 & 0.0042 & 0.0018 & 0.0039 & 0.0015 & 0.0002 & 0.0015 & 0.0003 & 0.0006 & 0.0036 \\
\hline & Gallionellaceae & 0.0001 & 0.0010 & 0.0004 & 0.0005 & 0.0001 & 0.0002 & 0.0004 & 0.0005 & 0.0005 & 0.0017 & 0.0023 & 0.0017 & 0.0004 & 0.0000 & 0.0004 & 0.0006 & 0.0000 & 0.0003 \\
\hline & seriaceae & 0.0004 & 0.0000 & 0.0003 & 0.0001 & 0.0004 & 0.0004 & 0.0001 & 0.0004 & 0.0004 & 0.0000 & 0.0002 & 0.0006 & 0.0000 & 0.0000 & 0.0006 & 0.0000 & 0.0003 & 0.0001 \\
\hline & Nitrosomonadaceae & 0.0005 & 0.0000 & 0.0000 & 0.0000 & 0.0000 & 0.0000 & 0.0000 & 0.0002 & 0.0000 & 0.0000 & 0.0000 & 0.0000 & 0.0001 & 0.0000 & 0.0000 & 0.0000 & 0.0000 & 0.0000 \\
\hline & ed members of Order Rhodocyclales & 0.0000 & 0.0004 & 0.0002 & 0.0000 & 0.0000 & 0.0000 & 0.0000 & 0.0000 & 0.0000 & 0.0000 & 0.0000 & 0.0000 & 0.0001 & 0.0001 & 0.0000 & 0.0000 & 0.0000 & 0.0000 \\
\hline & & 0.0042 & 0.0029 & 0.0018 & 0.0002 & 0.0002 & 0.0000 & 0.0028 & 0.0003 & 0.0000 & 0.0000 & 0.0000 & 0.0000 & 0.0005 & 0.0029 & 0.0014 & 0.0000 & 0.0000 & 0.0000 \\
\hline & Rhodoc & 0.0004 & 0.0000 & 0.0000 & 0.0000 & 0.0005 & 0.0003 & 0.0000 & 0.0000 & 0.0000 & 0.0000 & 0.0000 & 0.0000 & 0.0003 & 0.0000 & 0.0000 & 0.0000 & 0.0000 & 0.0000 \\
\hline \multirow[t]{16}{*}{ Deltaproteobacteria } & Unclassified Deltaproteobacteria & 0.0001 & 0.0005 & 0.0002 & 0.0000 & 0.0000 & 0.0001 & 0.0002 & 0.0002 & 0.0004 & 0.0000 & 0.0000 & 0.0002 & 0.0005 & 0.0001 & 0.0004 & 0.0005 & 0.0003 & 0.0000 \\
\hline & Unidentified family & 0.0002 & 0.0004 & 0.0002 & 0.0001 & 0.0017 & 0.0003 & 0.0010 & 0.0005 & 0.0003 & 0.0001 & 0.0001 & 0.0006 & 0.0008 & 0.0002 & 0.0000 & 0.0006 & 0.0008 & 0.0005 \\
\hline & Syntrophorhabdaceae & 0.0003 & 0.0001 & 0.0000 & 0.0001 & 0.0000 & 0.0001 & 0.0006 & 0.0004 & 0.0000 & 0.0006 & 0.0000 & 0.0000 & 0.0008 & 0.0004 & 0.0002 & 0.0004 & 0.0009 & 0.0002 \\
\hline & Bdellovibrionaceae & 0.0010 & 0.0002 & 0.0017 & 0.0003 & 0.0008 & 0.0004 & 0.0002 & 0.0008 & 0.0003 & 0.0004 & 0.0003 & 0.0008 & 0.0005 & 0.0011 & 0.0003 & 0.0002 & 0.0007 & 0.0003 \\
\hline & Unidentified family in Order CTD005-82B-02 & 0.0003 & 0.0000 & 0.0002 & 0.0002 & 0.0000 & 0.0003 & 0.0000 & 0.0001 & 0.0008 & 0.0000 & 0.0000 & 0.0000 & 0.0003 & 0.0002 & 0.0000 & 0.0006 & 0.0000 & 0.0000 \\
\hline & Desulfovibrionaceae & 0.0001 & 0.0001 & 0.0001 & 0.0002 & 0.0000 & 0.0002 & 0.0001 & 0.0004 & 0.0007 & 0.0025 & 0.0006 & 0.0008 & 0.0001 & 0.0002 & 0.0004 & 0.0000 & 0.0003 & 0.0000 \\
\hline & obacteraceae & 0.0050 & 0.0024 & 0.0045 & 0.0041 & 0.0004 & 0.0025 & 0.0015 & 0.0040 & 0.0021 & 0.0007 & 0.0007 & 0.0012 & 0.0031 & 0.0030 & 0.0016 & 0.0013 & 0.0003 & 0.0017 \\
\hline & Unidentified family in Order MIZ46 & 0.0024 & 0.0023 & 0.0024 & 0.0059 & 0.0071 & 0.0080 & 0.0060 & 0.0039 & 0.0061 & 0.0020 & 0.0037 & 0.0033 & 0.0044 & 0.0046 & 0.0048 & 0.0129 & 0.0111 & 0.0029 \\
\hline & Unclassified Myxococcales & 0.0022 & 0.0025 & 0.0025 & 0.0027 & 0.0018 & 0.0028 & 0.0033 & 0.0008 & 0.0020 & 0.0007 & 0.0009 & 0.0011 & 0.0053 & 0.0051 & 0.0049 & 0.0028 & 0.0026 & 0.0012 \\
\hline & identified family in Order Myxococcales & 0.0159 & 0.0106 & 0.0119 & 0.0207 & 0.0176 & 0.0253 & 0.0287 & 0.0166 & 0.0314 & 0.0207 & 0.0272 & 0.0136 & 0.0242 & 0.0157 & 0.0336 & 0.0230 & 0.0178 & 0.0129 \\
\hline & stobacteraceae & 0.0013 & 0.0011 & 0.0019 & 0.0002 & 0.0002 & 0.0004 & 0.0002 & 0.0004 & 0.0036 & 0.0000 & 0.0000 & 0.0000 & 0.0001 & 0.0004 & 0.0007 & 0.0000 & 0.0000 & 0.0000 \\
\hline & liangiaceae & 0.0131 & 0.0134 & 0.0148 & 0.0066 & 0.0036 & 0.0053 & 0.0073 & 0.0048 & 0.0058 & 0.0108 & 0.0136 & 0.0195 & 0.0172 & 0.0160 & 0.0224 & 0.0063 & 0.0011 & 0.0030 \\
\hline & & 0.0029 & 0.0021 & 0.0014 & 0.0008 & 0.0000 & 0.0001 & 0.0039 & 0.0088 & 0.0012 & 0.0005 & 0.0003 & 0.0000 & 0.0032 & 0.0041 & 0.0025 & 0.0020 & 0.0021 & 0.0005 \\
\hline & Polyangiaceae & 0.0016 & 0.0027 & 0.0019 & 0.0015 & 0.0026 & 0.0015 & 0.0013 & 0.0005 & 0.0009 & 0.0017 & 0.0013 & 0.0012 & 0.0022 & 0.0018 & 0.0013 & 0.0018 & 0.0023 & 0.0009 \\
\hline & Unclassified men & 0.0000 & 0.0000 & 0.0000 & 0.0000 & 0.0000 & 0.0000 & 0.0000 & 0.0001 & 0.0000 & 0.0000 & 0.0000 & 0.0000 & 0.0000 & 0.0001 & 0.0001 & 0.0000 & 0.0000 & 0.0000 \\
\hline & & 0.0003 & 0.0000 & 0.0000 & 0.0001 & 0.0000 & 0.0000 & 0.0000 & 0.0000 & 0.0000 & 0.0000 & 0.0000 & 0.0000 & 0.0000 & 0.0004 & 0.0001 & 0.0000 & 0.0000 & 0.0000 \\
\hline
\end{tabular}


Supplementary Table 5 page 5 of 6: Family-level Taxonomic Affiliation of Bacterial SSU rRNA amplicon reads (weighted abundance)

\begin{tabular}{|c|c|c|c|c|c|c|c|c|c|c|c|c|c|c|c|c|c|c|c|}
\hline & \multirow{2}{*}{$\begin{array}{l}\text { Treatment } \\
\text { Replicate }\end{array}$} & \multicolumn{3}{|c|}{ Control Lagg } & \multicolumn{3}{|c|}{ Control Bog } & \multicolumn{3}{|c|}{ Experimental Lagg } & \multicolumn{3}{|c|}{ Experimental Bog } & \multicolumn{3}{|c|}{ Recovery Lagg } & \multicolumn{3}{|c|}{ Recovery Bog } \\
\hline & & 1 & 2 & 3 & 1 & 2 & 3 & 1 & 2 & 3 & 1 & 2 & 3 & 1 & 2 & 3 & 1 & 2 & 3 \\
\hline & Number of high-quality sequences & 10365 & 10996 & 10369 & 13110 & 11669 & 9986 & 11657 & 11233 & 11547 & 10254 & 12152 & 8810 & 11964 & 12584 & 9720 & 11035 & 11549 & 8662 \\
\hline & Number of OTUs & 2017 & 2193 & 2228 & 2270 & 1863 & 1920 & 1834 & 2044 & 1806 & 1642 & 1723 & 1833 & 2140 & 1990 & 2098 & 1480 & 1549 & 1617 \\
\hline Phylum & Family or Candidate Family & & & & & & & & & & & & & & & & & & \\
\hline \multirow[t]{2}{*}{ Deltaproteobacteria } & Syntrophaceae & 0.0000 & 0.0000 & 0.0000 & 0.0000 & 0.0000 & 0.0000 & 0.0002 & 0.0001 & 0.0000 & 0.0000 & 0.0000 & 0.0000 & 0.0000 & 0.0001 & 0.0000 & 0.0000 & 0.0000 & 0.0000 \\
\hline & Syntrophobacteraceae & 0.0045 & 0.0045 & 0.0029 & 0.0031 & 0.0009 & 0.0013 & 0.0041 & 0.0031 & 0.0018 & 0.0059 & 0.0028 & 0.0015 & 0.0035 & 0.0027 & 0.0044 & 0.0033 & 0.0011 & 0.0013 \\
\hline \multirow[t]{21}{*}{ Gammaproteobacteria } & Unclassified Gammaproteobacteria & 0.0020 & 0.0032 & 0.0038 & 0.0026 & 0.0044 & 0.0052 & 0.0009 & 0.0039 & 0.0023 & 0.0028 & 0.0081 & 0.0065 & 0.0033 & 0.0032 & 0.0022 & 0.0029 & 0.0019 & 0.0020 \\
\hline & Unidentified Chromatiales & 0.0000 & 0.0000 & 0.0000 & 0.0001 & 0.0000 & 0.0001 & 0.0003 & 0.0001 & 0.0001 & 0.0000 & 0.0000 & 0.0000 & 0.0000 & 0.0000 & 0.0000 & 0.0001 & 0.0000 & 0.0000 \\
\hline & Unidentified family in Order Chromatiales & 0.0002 & 0.0000 & 0.0001 & 0.0000 & 0.0000 & 0.0000 & 0.0000 & 0.0000 & 0.0000 & 0.0000 & 0.0000 & 0.0000 & 0.0001 & 0.0001 & 0.0001 & 0.0000 & 0.0000 & 0.0000 \\
\hline & Sinobacteraceae & 0.0197 & 0.0240 & 0.0300 & 0.0309 & 0.0383 & 0.0335 & 0.0454 & 0.0288 & 0.0417 & 0.0392 & 0.0370 & 0.0471 & 0.0286 & 0.0312 & 0.0234 & 0.0249 & 0.0275 & 0.0361 \\
\hline & Enterobacteriaceae & 0.0000 & 0.0004 & 0.0002 & 0.0001 & 0.0000 & 0.0003 & 0.0000 & 0.0000 & 0.0000 & 0.0005 & 0.0000 & 0.0005 & 0.0000 & 0.0001 & 0.0001 & 0.0000 & 0.0002 & 0.0000 \\
\hline & Unclassified members of Order Legionellales & 0.0000 & 0.0004 & 0.0002 & 0.0005 & 0.0015 & 0.0004 & 0.0006 & 0.0004 & 0.0004 & 0.0008 & 0.0016 & 0.0008 & 0.0006 & 0.0002 & 0.0008 & 0.0002 & 0.0003 & 0.0009 \\
\hline & Coxiellaceae & 0.0096 & 0.0056 & 0.0033 & 0.0050 & 0.0050 & 0.0031 & 0.0029 & 0.0092 & 0.0053 & 0.0052 & 0.0059 & 0.0108 & 0.0064 & 0.0057 & 0.0115 & 0.0052 & 0.0062 & 0.0088 \\
\hline & Legionellaceae & 0.0002 & 0.0011 & 0.0006 & 0.0005 & 0.0015 & 0.0005 & 0.0001 & 0.0012 & 0.0006 & 0.0003 & 0.0008 & 0.0005 & 0.0009 & 0.0014 & 0.0012 & 0.0006 & 0.0018 & 0.0016 \\
\hline & Crenotrichaceae & 0.0000 & 0.0000 & 0.0000 & 0.0000 & 0.0000 & 0.0000 & 0.0000 & 0.0001 & 0.0003 & 0.0000 & 0.0000 & 0.0000 & 0.0007 & 0.0005 & 0.0003 & 0.0000 & 0.0000 & 0.0000 \\
\hline & Methylococcaceae & 0.0004 & 0.0010 & 0.0004 & 0.0005 & 0.0001 & 0.0005 & 0.0003 & 0.0004 & 0.0006 & 0.0002 & 0.0000 & 0.0003 & 0.0022 & 0.0004 & 0.0004 & 0.0000 & 0.0000 & 0.0006 \\
\hline & Unclassified members of Order Oceanospirillales & 0.0002 & 0.0000 & 0.0000 & 0.0000 & 0.0002 & 0.0000 & 0.0000 & 0.0000 & 0.0002 & 0.0000 & 0.0000 & 0.0000 & 0.0009 & 0.0002 & 0.0000 & 0.0000 & 0.0003 & 0.0000 \\
\hline & Unidentified family in Order Pseudomonadales & 0.0000 & 0.0000 & 0.0000 & 0.0000 & 0.0000 & 0.0000 & 0.0000 & 0.0001 & 0.0000 & 0.0000 & 0.0000 & 0.0000 & 0.0002 & 0.0000 & 0.0000 & 0.0000 & 0.0000 & 0.0000 \\
\hline & Moraxellaceae & 0.0000 & 0.0000 & 0.0000 & 0.0000 & 0.0002 & 0.0000 & 0.0000 & 0.0000 & 0.0000 & 0.0003 & 0.0000 & 0.0000 & 0.0000 & 0.0000 & 0.0000 & 0.0000 & 0.0000 & 0.0000 \\
\hline & Pseudomonadaceae & 0.0010 & 0.0006 & 0.0003 & 0.0002 & 0.0006 & 0.0007 & 0.0000 & 0.0001 & 0.0011 & 0.0003 & 0.0009 & 0.0005 & 0.0000 & 0.0000 & 0.0001 & 0.0003 & 0.0000 & 0.0005 \\
\hline & Unclassified members of Order Thiotrichales & 0.0001 & 0.0000 & 0.0000 & 0.0000 & 0.0001 & 0.0004 & 0.0002 & 0.0001 & 0.0001 & 0.0002 & 0.0002 & 0.0001 & 0.0000 & 0.0002 & 0.0003 & 0.0001 & 0.0000 & 0.0003 \\
\hline & Unidentified family in Order Thiotrichales & 0.0009 & 0.0005 & 0.0005 & 0.0014 & 0.0010 & 0.0007 & 0.0003 & 0.0005 & 0.0013 & 0.0008 & 0.0016 & 0.0022 & 0.0007 & 0.0012 & 0.0017 & 0.0009 & 0.0018 & 0.0027 \\
\hline & Endoecteinascidiaceae & 0.0000 & 0.0000 & 0.0000 & 0.0000 & 0.0000 & 0.0000 & 0.0000 & 0.0000 & 0.0000 & 0.0000 & 0.0000 & 0.0000 & 0.0000 & 0.0003 & 0.0000 & 0.0001 & 0.0000 & 0.0000 \\
\hline & Unclassified members of Order Xanthomonadales & 0.0000 & 0.0000 & 0.0001 & 0.0000 & 0.0000 & 0.0002 & 0.0000 & 0.0000 & 0.0000 & 0.0000 & 0.0000 & 0.0000 & 0.0000 & 0.0000 & 0.0001 & 0.0000 & 0.0000 & 0.0000 \\
\hline & Unidentified family in Order Xanthomonadales & 0.0000 & 0.0000 & 0.0000 & 0.0000 & 0.0000 & 0.0000 & 0.0000 & 0.0002 & 0.0000 & 0.0000 & 0.0000 & 0.0000 & 0.0000 & 0.0000 & 0.0000 & 0.0000 & 0.0000 & 0.0000 \\
\hline & Sinobacteraceae & 0.0002 & 0.0000 & 0.0001 & 0.0001 & 0.0001 & 0.0000 & 0.0003 & 0.0004 & 0.0000 & 0.0001 & 0.0000 & 0.0000 & 0.0012 & 0.0005 & 0.0005 & 0.0000 & 0.0000 & 0.0000 \\
\hline & Xanthomonadaceae & 0.0059 & 0.0074 & 0.0054 & 0.0038 & 0.0018 & 0.0039 & 0.0024 & 0.0020 & 0.0139 & 0.0020 & 0.0032 & 0.0076 & 0.0107 & 0.0046 & 0.0034 & 0.0013 & 0.0007 & 0.0005 \\
\hline SC3 & Unidentified family & 0.0015 & 0.0010 & 0.0004 & 0.0008 & 0.0009 & 0.0010 & 0.0009 & 0.0003 & 0.0002 & 0.0000 & 0.0005 & 0.0001 & 0.0003 & 0.0017 & 0.0002 & 0.0001 & 0.0011 & 0.0001 \\
\hline \multirow[t]{2}{*}{ sC4 } & Unidentified family & 0.0000 & 0.0003 & 0.0000 & 0.0000 & 0.0000 & 0.0002 & 0.0000 & 0.0002 & 0.0000 & 0.0000 & 0.0000 & 0.0000 & 0.0000 & 0.0000 & 0.0000 & 0.0000 & 0.0000 & 0.0000 \\
\hline & Unidentified family in Class KD3-113 & 0.0001 & 0.0000 & 0.0000 & 0.0000 & 0.0000 & 0.0000 & 0.0003 & 0.0000 & 0.0002 & 0.0000 & 0.0000 & 0.0002 & 0.0001 & 0.0002 & 0.0001 & 0.0005 & 0.0003 & 0.0003 \\
\hline$S M 2 F 11$ & Unidentified family & 0.0007 & 0.0009 & 0.0002 & 0.0003 & 0.0003 & 0.0001 & 0.0001 & 0.0003 & 0.0000 & 0.0005 & 0.0007 & 0.0001 & 0.0005 & 0.0003 & 0.0007 & 0.0000 & 0.0001 & 0.0000 \\
\hline Spirochaetes & Spirochaetaceae & 0.0040 & 0.0018 & 0.0005 & 0.0006 & 0.0020 & 0.0012 & 0.0013 & 0.0021 & 0.0004 & 0.0002 & 0.0010 & 0.0000 & 0.0061 & 0.0027 & 0.0037 & 0.0012 & 0.0001 & 0.0000 \\
\hline \multirow[t]{2}{*}{ TG3 } & Unclassified TG3 & 0.0000 & 0.0002 & 0.0000 & 0.0000 & 0.0000 & 0.0000 & 0.0000 & 0.0000 & 0.0000 & 0.0000 & 0.0000 & 0.0000 & 0.0000 & 0.0000 & 0.0000 & 0.0000 & 0.0000 & 0.0000 \\
\hline & Unclassified members of Class TG3-1 & 0.0000 & 0.0000 & 0.0000 & 0.0000 & 0.0000 & 0.0000 & 0.0000 & 0.0001 & 0.0000 & 0.0000 & 0.0000 & 0.0000 & 0.0005 & 0.0000 & 0.0008 & 0.0000 & 0.0001 & 0.0000 \\
\hline \multirow[t]{3}{*}{ TM6 } & Unclassified TM6 & 0.0000 & 0.0001 & 0.0000 & 0.0002 & 0.0000 & 0.0000 & 0.0000 & 0.0002 & 0.0001 & 0.0003 & 0.0000 & 0.0002 & 0.0015 & 0.0006 & 0.0001 & 0.0000 & 0.0005 & 0.0000 \\
\hline & Unidentified family in Class SBRH58 & 0.0000 & 0.0000 & 0.0000 & 0.0000 & 0.0000 & 0.0000 & 0.0000 & 0.0000 & 0.0002 & 0.0000 & 0.0000 & 0.0001 & 0.0000 & 0.0000 & 0.0000 & 0.0000 & 0.0000 & 0.0000 \\
\hline & Unidentified family in Class SJA-4 & 0.0097 & 0.0045 & 0.0036 & 0.0053 & 0.0040 & 0.0059 & 0.0036 & 0.0062 & 0.0039 & 0.0062 & 0.0086 & 0.0156 & 0.0033 & 0.0021 & 0.0077 & 0.0065 & 0.0126 & 0.0055 \\
\hline \multirow[t]{5}{*}{ TM7 } & Unclassified TM7 & 0.0004 & 0.0003 & 0.0003 & 0.0002 & 0.0005 & 0.0009 & 0.0003 & 0.0002 & 0.0004 & 0.0008 & 0.0003 & 0.0000 & 0.0019 & 0.0014 & 0.0024 & 0.0001 & 0.0001 & 0.0007 \\
\hline & Unidentified family in Class TM7-1 & 0.0035 & 0.0013 & 0.0034 & 0.0021 & 0.0062 & 0.0042 & 0.0054 & 0.0039 & 0.0016 & 0.0066 & 0.0096 & 0.0081 & 0.0018 & 0.0024 & 0.0055 & 0.0171 & 0.0088 & 0.0018 \\
\hline & Unclassified members of Class TM7-3 & 0.0000 & 0.0000 & 0.0000 & 0.0000 & 0.0000 & 0.0001 & 0.0000 & 0.0000 & 0.0003 & 0.0000 & 0.0000 & 0.0000 & 0.0000 & 0.0000 & 0.0000 & 0.0000 & 0.0000 & 0.0000 \\
\hline & Unidentified family in Order Blgi18 & 0.0000 & 0.0001 & 0.0001 & 0.0001 & 0.0000 & 0.0001 & 0.0000 & 0.0000 & 0.0003 & 0.0000 & 0.0002 & 0.0007 & 0.0000 & 0.0002 & 0.0000 & 0.0000 & 0.0000 & 0.0002 \\
\hline & Unidentified family in Order EW055 & 0.0000 & 0.0000 & 0.0000 & 0.0000 & 0.0000 & 0.0000 & 0.0000 & 0.0003 & 0.0000 & 0.0000 & 0.0000 & 0.0000 & 0.0000 & 0.0000 & 0.0000 & 0.0000 & 0.0000 & 0.0000 \\
\hline Tenericutes & Unidentified family & 0.0002 & 0.0000 & 0.0000 & 0.0000 & 0.0000 & 0.0000 & 0.0000 & 0.0000 & 0.0000 & 0.0000 & 0.0000 & 0.0000 & 0.0000 & 0.0000 & 0.0000 & 0.0000 & 0.0000 & 0.0000 \\
\hline
\end{tabular}


Supplementary Table 5 page 6 of 6: Family-level Taxonomic Affiliation of Bacterial SSU rRNA amplicon reads (weighted abundance)

\begin{tabular}{|c|c|c|c|c|c|c|c|c|c|c|c|c|c|c|c|c|c|c|c|}
\hline & \multirow{2}{*}{$\begin{array}{l}\text { Treatment } \\
\text { Replicate }\end{array}$} & \multicolumn{3}{|c|}{ Control Lagg } & \multicolumn{3}{|c|}{ Control Bog } & \multicolumn{3}{|c|}{ Experimental Lagg } & \multicolumn{3}{|c|}{ Experimental Bog } & \multicolumn{3}{|c|}{ Recovery Lagg } & \multicolumn{3}{|c|}{ Recovery Bog } \\
\hline & & 1 & 2 & 3 & 1 & 2 & 3 & 1 & 2 & 3 & 1 & 2 & 3 & 1 & 2 & 3 & 1 & 2 & 3 \\
\hline & Number of high-quality sequences & 10365 & 10996 & 10369 & 13110 & 11669 & 9986 & 11657 & 11233 & 11547 & 10254 & 12152 & 8810 & 11964 & 12584 & 9720 & 11035 & 11549 & 8662 \\
\hline & Number of OTUs & 2017 & 2193 & 2228 & 2270 & 1863 & 1920 & 1834 & 2044 & 1806 & 1642 & 1723 & 1833 & 2140 & 1990 & 2098 & 1480 & 1549 & 1617 \\
\hline Phylum & Family or Candidate Family & & & & & & & & & & & & & & & & & & \\
\hline \multirow[t]{13}{*}{ Verrucomicrobia } & Unclassified Verrucomicrobia & 0.0014 & 0.0016 & 0.0045 & 0.0008 & 0.0004 & 0.0012 & 0.0026 & 0.0013 & 0.0010 & 0.0055 & 0.0007 & 0.0010 & 0.0019 & 0.0016 & 0.0020 & 0.0045 & 0.0017 & 0.0022 \\
\hline & Unidentified family & 0.0003 & 0.0000 & 0.0000 & 0.0000 & 0.0002 & 0.0000 & 0.0000 & 0.0000 & 0.0000 & 0.0000 & 0.0000 & 0.0000 & 0.0002 & 0.0000 & 0.0000 & 0.0000 & 0.0000 & 0.0000 \\
\hline & LD19 & 0.0002 & 0.0001 & 0.0007 & 0.0006 & 0.0009 & 0.0053 & 0.0003 & 0.0004 & 0.0008 & 0.0012 & 0.0006 & 0.0007 & 0.0000 & 0.0009 & 0.0000 & 0.0006 & 0.0011 & 0.0005 \\
\hline & Unclassified Verrucomicrobia in Class Opitutae & 0.0003 & 0.0005 & 0.0017 & 0.0008 & 0.0008 & 0.0024 & 0.0011 & 0.0005 & 0.0003 & 0.0010 & 0.0014 & 0.0018 & 0.0010 & 0.0012 & 0.0007 & 0.0005 & 0.0002 & 0.0015 \\
\hline & Unidentified family in Class Opitutae & 0.0000 & 0.0000 & 0.0002 & 0.0002 & 0.0001 & 0.0000 & 0.0001 & 0.0000 & 0.0000 & 0.0002 & 0.0001 & 0.0000 & 0.0000 & 0.0002 & 0.0000 & 0.0000 & 0.0000 & 0.0006 \\
\hline & Opitutaceae & 0.0146 & 0.0102 & 0.0090 & 0.0327 & 0.0405 & 0.0361 & 0.0314 & 0.0401 & 0.0443 & 0.0196 & 0.0214 & 0.0270 & 0.0558 & 0.0199 & 0.0519 & 0.0269 & 0.0210 & 0.0364 \\
\hline & Puniceicoccaceae & 0.0000 & 0.0000 & 0.0000 & 0.0000 & 0.0000 & 0.0000 & 0.0000 & 0.0000 & 0.0000 & 0.0000 & 0.0000 & 0.0000 & 0.0002 & 0.0000 & 0.0000 & 0.0000 & 0.0000 & 0.0000 \\
\hline & Spartobacteriaceae & 0.0029 & 0.0020 & 0.0038 & 0.0013 & 0.0014 & 0.0015 & 0.0004 & 0.0004 & 0.0015 & 0.0020 & 0.0005 & 0.0008 & 0.0002 & 0.0006 & 0.0001 & 0.0015 & 0.0003 & 0.0008 \\
\hline & Unidentified family in Class Verruco-5 & 0.0000 & 0.0000 & 0.0000 & 0.0002 & 0.0000 & 0.0000 & 0.0000 & 0.0001 & 0.0000 & 0.0000 & 0.0000 & 0.0000 & 0.0000 & 0.0000 & 0.0000 & 0.0000 & 0.0000 & 0.0000 \\
\hline & Unclassified members of Order Verrucomicrobiales & 0.0011 & 0.0007 & 0.0008 & 0.0003 & 0.0002 & 0.0003 & 0.0006 & 0.0004 & 0.0001 & 0.0003 & 0.0002 & 0.0003 & 0.0011 & 0.0006 & 0.0013 & 0.0006 & 0.0009 & 0.0003 \\
\hline & VerrucomicrobialesUnidentified family & 0.0049 & 0.0044 & 0.0129 & 0.0031 & 0.0069 & 0.0088 & 0.0032 & 0.0044 & 0.0065 & 0.0150 & 0.0067 & 0.0066 & 0.0048 & 0.0033 & 0.0027 & 0.0067 & 0.0030 & 0.0074 \\
\hline & Verrucomicrobia subdivision 3 & 0.0035 & 0.0020 & 0.0040 & 0.0005 & 0.0007 & 0.0006 & 0.0013 & 0.0014 & 0.0014 & 0.0013 & 0.0004 & 0.0001 & 0.0018 & 0.0011 & 0.0022 & 0.0009 & 0.0001 & 0.0005 \\
\hline & Verrucomicrobiaceae & 0.0001 & 0.0007 & 0.0009 & 0.0000 & 0.0000 & 0.0004 & 0.0000 & 0.0000 & 0.0001 & 0.0003 & 0.0000 & 0.0001 & 0.0001 & 0.0000 & 0.0001 & 0.0000 & 0.0000 & 0.0001 \\
\hline WPS-2 & Unidentified family & 0.0132 & 0.0154 & 0.0414 & 0.0296 & 0.0600 & 0.0399 & 0.0398 & 0.0523 & 0.0332 & 0.0495 & 0.0481 & 0.0381 & 0.0306 & 0.0254 & 0.0310 & 0.0733 & 0.0473 & 0.0544 \\
\hline wS1 & Unidentified family & 0.0000 & 0.0000 & 0.0000 & 0.0000 & 0.0000 & 0.0000 & 0.0000 & 0.0000 & 0.0000 & 0.0000 & 0.0000 & 0.0000 & 0.0001 & 0.0000 & 0.0001 & 0.0000 & 0.0000 & 0.0000 \\
\hline \multirow[t]{2}{*}{ WS3 } & Unidentified family in Order Sediment- 1 & 0.0000 & 0.0001 & 0.0000 & 0.0000 & 0.0000 & 0.0000 & 0.0006 & 0.0000 & 0.0000 & 0.0000 & 0.0000 & 0.0000 & 0.0000 & 0.0000 & 0.0000 & 0.0000 & 0.0000 & 0.0000 \\
\hline & PRR-10 & 0.0002 & 0.0000 & 0.0000 & 0.0000 & 0.0000 & 0.0000 & 0.0000 & 0.0000 & 0.0000 & 0.0000 & 0.0000 & 0.0000 & 0.0000 & 0.0000 & 0.0002 & 0.0000 & 0.0000 & 0.0000 \\
\hline
\end{tabular}




\subsubsection{Supplmementary Table 7.1.6: Lagg OTUs with a significant correlation between weighted abundance and the percentage of mercury present as methylmercury $(\% \mathrm{MeHg})$}

Supplementary Table 6 page 1 of 3: Lagg OTUs with a significant correlation between weighted abundance and the percentage of mercury present as methylmercury (\%-MeHg)

\begin{tabular}{|c|c|c|c|c|c|c|c|c|c|c|c|}
\hline \multirow{2}{*}{$\begin{array}{l}\text { Treatment } \\
\text { Replicate } \\
\text { Associated \%-MeHg value }\end{array}$} & & & \multicolumn{3}{|c|}{ Control Lagg } & \multicolumn{3}{|c|}{ Experimental Lagg } & \multicolumn{3}{|c|}{ Recovery Lagg } \\
\hline & & & $\begin{array}{c}1 \\
12.8 \\
\end{array}$ & $\begin{array}{c}2 \\
7.4 \\
\end{array}$ & $\begin{array}{c}3 \\
15.7 \\
\end{array}$ & $\begin{array}{c}1 \\
10.2 \\
\end{array}$ & $\begin{array}{c}2 \\
10.4 \\
\end{array}$ & $\begin{array}{r}3 \\
8.7 \\
\end{array}$ & $\begin{array}{c}1 \\
9.3 \\
\end{array}$ & $\begin{array}{c}2 \\
6.9 \\
\end{array}$ & $\begin{array}{c}3 \\
6.5 \\
\end{array}$ \\
\hline Taxonomic Affiliation of OTU* & $r$-value & p-value & \multicolumn{9}{|c|}{ Weighted Abundances } \\
\hline Unidentified Bacteria & 0.898 & 0.0010 & 0.00034 & 0.00000 & 0.00087 & 0.00018 & 0.00000 & 0.00000 & 0.00000 & 0.00000 & 0.00000 \\
\hline Unidentified Bacteria & 0.817 & 0.0072 & 0.00009 & 0.00000 & 0.00052 & 0.00000 & 0.00000 & 0.00000 & 0.00000 & 0.00000 & 0.00000 \\
\hline Unidentified Bacteria & 0.800 & 0.0096 & 0.00017 & 0.00017 & 0.00052 & 0.00018 & 0.00010 & 0.00000 & 0.00029 & 0.00000 & 0.00000 \\
\hline Acidobacteria; c_;o_ & -0.807 & 0.0085 & 0.00009 & 0.00017 & 0.00000 & 0.00009 & 0.00010 & 0.00027 & 0.00029 & 0.00024 & 0.00041 \\
\hline Acidobacteria; c_;o_;f_ & 0.855 & 0.0033 & 0.00009 & 0.00000 & 0.00009 & 0.00000 & 0.00000 & 0.00000 & 0.00000 & 0.00000 & 0.00000 \\
\hline Acidobacteria; c_Acidobacteria; o_Acidobacteriales; f_Acidobacteriaceae & 0.898 & 0.0010 & 0.00172 & 0.00008 & 0.00329 & 0.00169 & 0.00029 & 0.00018 & 0.00010 & 0.00008 & 0.00021 \\
\hline Acidobacteria; c_Acidobacteria; o_Acidobacteriales; f_Acidobacteriaceae & 0.884 & 0.0016 & 0.00034 & 0.00008 & 0.00061 & 0.00045 & 0.00029 & 0.00027 & 0.00039 & 0.00008 & 0.00010 \\
\hline Acidobacteria; c_Acidobacteria; o_Acidobacteriales; f_Acidobacteriaceae & 0.883 & 0.0016 & 0.00009 & 0.00000 & 0.00017 & 0.00009 & 0.00000 & 0.00000 & 0.00000 & 0.00000 & 0.00000 \\
\hline Acidobacteria; c_Acidobacteria; o_Acidobacteriales; f_Acidobacteriaceae & 0.883 & 0.0016 & 0.00472 & 0.00309 & 0.01308 & 0.00418 & 0.00280 & 0.00236 & 0.00241 & 0.00175 & 0.00123 \\
\hline Acidobacteria; C_Acidobacteria; O_Acidobacteriales; f_Acidobacteriaceae & 0.882 & 0.0016 & 0.00146 & 0.00042 & 0.00286 & 0.00151 & 0.00087 & 0.00118 & 0.00048 & 0.00079 & 0.00051 \\
\hline Acidobacteria; c_Acidobacteria; o_Acidobacteriales; f_Acidobacteriaceae & 0.874 & 0.0021 & 0.00077 & 0.00050 & 0.00165 & 0.00062 & 0.00058 & 0.00009 & 0.00019 & 0.00032 & 0.00021 \\
\hline Acidobacteria; c_Acidobacteria; o_Acidobacteriales; f_Acidobacteriaceae & 0.869 & 0.0024 & 0.00017 & 0.00008 & 0.00017 & 0.00009 & 0.00010 & 0.00000 & 0.00010 & 0.00000 & 0.00000 \\
\hline Acidobacteria; $c \_$Acidobacteria; o_Acidobacteriales; f_Acidobacteriaceae & 0.861 & 0.0028 & 0.00043 & 0.00000 & 0.00156 & 0.00036 & 0.00077 & 0.00018 & 0.00010 & 0.00008 & 0.00021 \\
\hline Acidobacteria; c_Acidobacteria; o_Acidobacteriales; f_Acidobacteriaceae & 0.855 & 0.0033 & 0.00009 & 0.00000 & 0.00009 & 0.00000 & 0.00000 & 0.00000 & 0.00000 & 0.00000 & 0.00000 \\
\hline Acidobacteria; c_Acidobacteria; o_Acidobacteriales; f_Acidobacteriaceae & 0.855 & 0.0033 & 0.00009 & 0.00000 & 0.00009 & 0.00000 & 0.00000 & 0.00000 & 0.00000 & 0.00000 & 0.00000 \\
\hline Acidobacteria; c_Acidobacteria; o_Acidobacteriales; f_Acidobacteriaceae & 0.855 & 0.0033 & 0.00009 & 0.00000 & 0.00009 & 0.00000 & 0.00000 & 0.00000 & 0.00000 & 0.00000 & 0.00000 \\
\hline Acidobacteria; $c \_$Acidobacteria; o_Acidobacteriales; f_Acidobacteriaceae & 0.852 & 0.0035 & 0.00197 & 0.00142 & 0.00346 & 0.00178 & 0.00077 & 0.00118 & 0.00058 & 0.00048 & 0.00072 \\
\hline Acidobacteria; C_Acidobacteria; O_Acidobacteriales; f_Acidobacteriaceae & 0.846 & 0.0041 & 0.00034 & 0.00000 & 0.00043 & 0.00018 & 0.00010 & 0.00018 & 0.00000 & 0.00016 & 0.00000 \\
\hline Acidobacteria; c_Acidobacteria; o_Acidobacteriales; f_Acidobacteriaceae & 0.841 & 0.0045 & 0.00060 & 0.00017 & 0.00121 & 0.00036 & 0.00000 & 0.00000 & 0.00000 & 0.00016 & 0.00010 \\
\hline Acidobacteria; c_Acidobacteria; o_Acidobacteriales; f_Acidobacteriaceae & 0.840 & 0.0046 & 0.00017 & 0.00000 & 0.00035 & 0.00018 & 0.00019 & 0.00018 & 0.00000 & 0.00008 & 0.00000 \\
\hline Acidobacteria; c_Acidobacteria; o_Acidobacteriales; f_Acidobacteriaceae & 0.835 & 0.0051 & 0.00086 & 0.00042 & 0.00113 & 0.00089 & 0.00048 & 0.00064 & 0.00019 & 0.00032 & 0.00031 \\
\hline Acidobacteria; c_Acidobacteria; o_Acidobacteriales; f_Acidobacteriaceae & 0.817 & 0.0072 & 0.00009 & 0.00000 & 0.00052 & 0.00000 & 0.00000 & 0.00000 & 0.00000 & 0.00000 & 0.00000 \\
\hline Acidobacteria; C_Acidobacteria; o_Acidobacteriales; f_Acidobacteriaceae & 0.807 & 0.0086 & 0.00112 & 0.00042 & 0.00303 & 0.00151 & 0.00010 & 0.00009 & 0.00039 & 0.00056 & 0.00031 \\
\hline Acidobacteria; c_Acidobacteria; o_Acidobacteriales; f_Acidobacteriaceae & 0.803 & 0.0091 & 0.00026 & 0.00025 & 0.00087 & 0.00027 & 0.00058 & 0.00000 & 0.00000 & 0.00000 & 0.00000 \\
\hline Acidobacteria; c_Acidobacteria; o_Acidobacteriales; f_Acidobacteriaceae & 0.802 & 0.0094 & 0.00069 & 0.00033 & 0.00909 & 0.00214 & 0.00106 & 0.00045 & 0.00010 & 0.00032 & 0.00010 \\
\hline Acidobacteria; $c \_$Acidobacteria; o_Acidobacteriales; f_Acidobacteriaceae & 0.799 & 0.0098 & 0.00026 & 0.00000 & 0.00277 & 0.00053 & 0.00000 & 0.00000 & 0.00000 & 0.00008 & 0.00000 \\
\hline Acidobacteria; c_Solibacteres; o_Solibacterales; $;$ _Solibacteraceae & 0.890 & 0.0013 & 0.00034 & 0.00008 & 0.00069 & 0.00018 & 0.00048 & 0.00009 & 0.00010 & 0.00000 & 0.00010 \\
\hline Acidobacteria; c_Solibacteres; o_Solibacterales; $;$ _Solibacteraceae & 0.855 & 0.0033 & 0.00009 & 0.00000 & 0.00009 & 0.00000 & 0.00000 & 0.00000 & 0.00000 & 0.00000 & 0.00000 \\
\hline Acidobacteria; c_Solibacteres; o_Solibacterales; $f$ _Solibacteraceae & 0.855 & 0.0033 & 0.00009 & 0.00000 & 0.00009 & 0.00000 & 0.00000 & 0.00000 & 0.00000 & 0.00000 & 0.00000 \\
\hline Acidobacteria; c_Solibacteres; o_Solibacterales; ;_Solibacteraceae & -0.848 & 0.0039 & 0.00009 & 0.00050 & 0.00009 & 0.00009 & 0.00029 & 0.00055 & 0.00048 & 0.00087 & 0.00093 \\
\hline Acidobacteria; $;$ _Solibacteres; o_Solibacterales; $;$ _Solibacteraceae & 0.829 & 0.0058 & 0.00017 & 0.00008 & 0.00035 & 0.00000 & 0.00000 & 0.00000 & 0.00000 & 0.00000 & 0.00000 \\
\hline Acidobacteria; c_Solibacteres; o_Solibacterales; f_Solibacteraceae & 0.802 & 0.0093 & 0.00026 & 0.00000 & 0.00087 & 0.00009 & 0.00068 & 0.00018 & 0.00010 & 0.00008 & 0.00000 \\
\hline Actinobacteria; c_Actinobacteria; O_Acidimicrobiales; f__ & 0.882 & 0.0017 & 0.00069 & 0.00017 & 0.00069 & 0.00062 & 0.00058 & 0.00036 & 0.00029 & 0.00000 & 0.00010 \\
\hline Actinobacteria; ;_Actinobacteria; O_Acidimicrobiales; f_- & 0.826 & 0.0060 & 0.00017 & 0.00008 & 0.00069 & 0.00009 & 0.00019 & 0.00000 & 0.00000 & 0.00000 & 0.00010 \\
\hline Actinobacteria; c_Actinobacteria; o_Actinomycetales & 0.854 & 0.0034 & 0.00034 & 0.00017 & 0.00156 & 0.00036 & 0.00068 & 0.00009 & 0.00039 & 0.00024 & 0.00000 \\
\hline Actinobacteria; c_Actinobacteria; o_Actinomycetales & -0.846 & 0.0041 & 0.00034 & 0.00134 & 0.00009 & 0.00009 & 0.00048 & 0.00127 & 0.00068 & 0.00143 & 0.00195 \\
\hline Actinobacteria; c_Actinobacteria; o_Solirubrobacterales & 0.813 & 0.0078 & 0.00009 & 0.00000 & 0.00035 & 0.00000 & 0.00000 & 0.00009 & 0.00000 & 0.00000 & 0.00000 \\
\hline Actinobacteria; c_Actinobacteria; o Solirubrobacterales & 0.801 & 0.0094 & 0.00009 & 0.00000 & 0.00069 & 0.00000 & 0.00000 & 0.00000 & 0.00000 & 0.00000 & 0.00000 \\
\hline
\end{tabular}



rcrit $=0.798 \alpha=0.01$

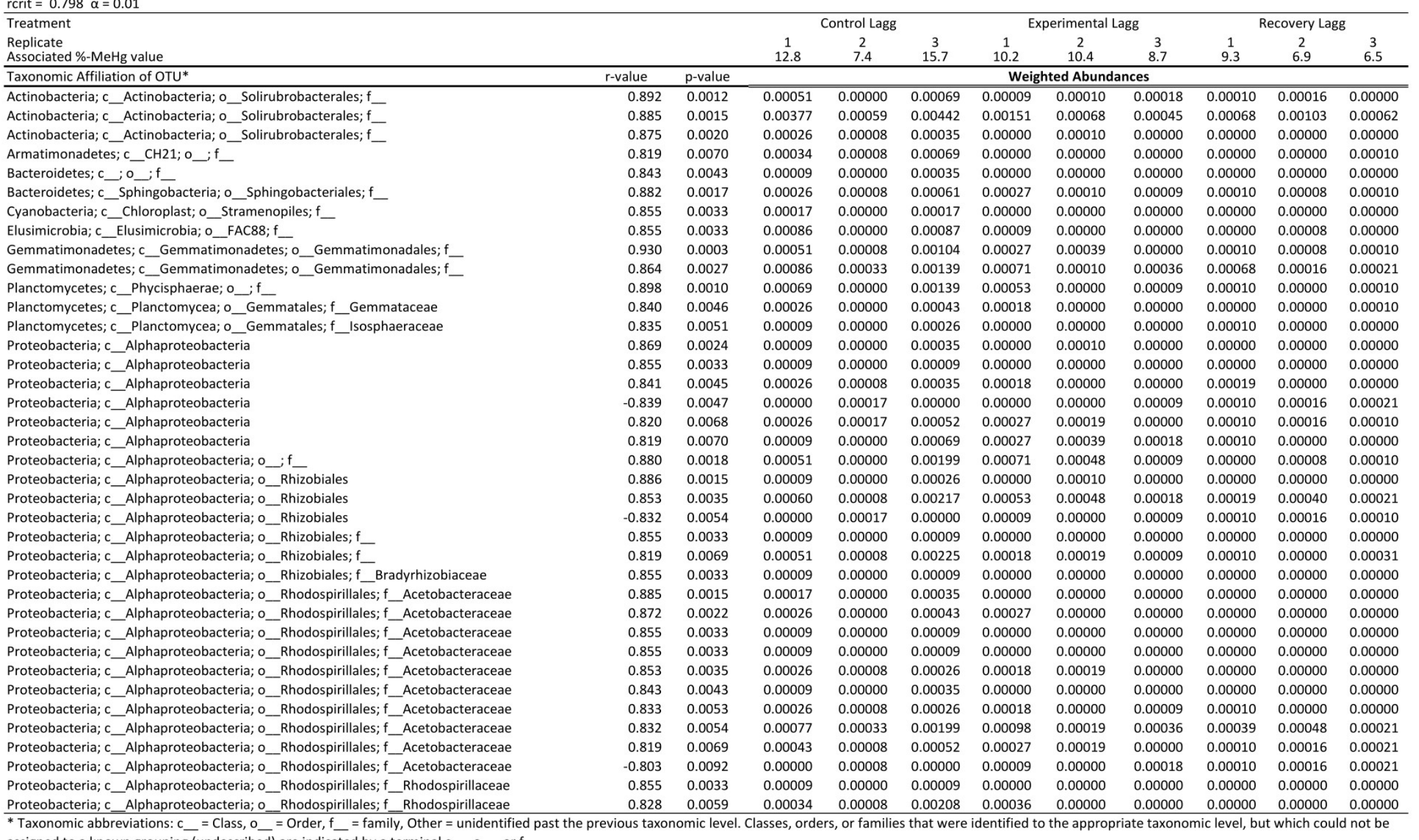

assigned to a known grouping (undescribed) are indicated by a terminal $c, 0$, or $f$ 
Supplementary Table 6 page 3 of 3: Lagg OTUs with a significant correlation between weighted abundance and the percentage of mercury present as methylmercury (\%-MeHg)

\begin{tabular}{|c|c|c|c|c|c|c|c|c|c|c|c|}
\hline \multirow{2}{*}{$\begin{array}{l}\text { Treatment } \\
\text { Replicate } \\
\text { Associated \%-MeHg value }\end{array}$} & & & \multicolumn{3}{|c|}{ Control Lagg } & \multicolumn{3}{|c|}{ Experimental Lagg } & \multicolumn{3}{|c|}{ Recovery Lagg } \\
\hline & & & $\begin{array}{c}1 \\
12.8\end{array}$ & $\begin{array}{c}2 \\
7.4\end{array}$ & $\begin{array}{c}3 \\
15.7\end{array}$ & $\begin{array}{c}1 \\
10.2\end{array}$ & $\begin{array}{c}2 \\
10.4\end{array}$ & $\begin{array}{c}3 \\
8.7\end{array}$ & $\begin{array}{c}1 \\
9.3\end{array}$ & $\begin{array}{c}2 \\
6.9 \\
\end{array}$ & $\begin{array}{c}3 \\
6.5\end{array}$ \\
\hline Taxonomic Affiliation of OTU* & $r$-value & $\mathrm{p}$-value & \multicolumn{9}{|c|}{ Weighted Abundances } \\
\hline Proteobacteria; c_Betaproteobacteria; o__Burkholderiales; f__ & 0.912 & 0.0006 & 0.00249 & 0.00042 & 0.00242 & 0.00053 & 0.00106 & 0.00045 & 0.00116 & 0.00032 & 0.00031 \\
\hline Proteobacteria; c_Betaproteobacteria; o__Burkholderiales; f_ & 0.888 & 0.0014 & 0.00180 & 0.00067 & 0.00173 & 0.00062 & 0.00106 & 0.00027 & 0.00106 & 0.00040 & 0.00010 \\
\hline Proteobacteria; c_Deltaproteobacteria; o_MIZ46; f__ & 0.885 & 0.0015 & 0.00009 & 0.00000 & 0.00017 & 0.00000 & 0.00000 & 0.00000 & 0.00000 & 0.00000 & 0.00000 \\
\hline Proteobacteria; c_Deltaproteobacteria; o__MIZ46; f__ & 0.855 & 0.0033 & 0.00009 & 0.00000 & 0.00009 & 0.00000 & 0.00000 & 0.00000 & 0.00000 & 0.00000 & 0.00000 \\
\hline Proteobacteria; c_Deltaproteobacteria; o__MIZ46; f__ & 0.843 & 0.0043 & 0.00009 & 0.00000 & 0.00035 & 0.00000 & 0.00000 & 0.00000 & 0.00000 & 0.00000 & 0.00000 \\
\hline Proteobacteria; c_Deltaproteobacteria; o_Myxococcales; f__ & 0.912 & 0.0006 & 0.00154 & 0.00067 & 0.00217 & 0.00142 & 0.00068 & 0.00027 & 0.00077 & 0.00016 & 0.00041 \\
\hline Proteobacteria; c_Deltaproteobacteria; o_Myxococcales; f__ & 0.897 & 0.0011 & 0.00197 & 0.00017 & 0.00424 & 0.00125 & 0.00010 & 0.00000 & 0.00000 & 0.00000 & 0.00021 \\
\hline Proteobacteria; c_Deltaproteobacteria; o_Myxococcales; f__ & 0.893 & 0.0012 & 0.00060 & 0.00000 & 0.00069 & 0.00000 & 0.00010 & 0.00000 & 0.00000 & 0.00000 & 0.00000 \\
\hline Proteobacteria; c_Deltaproteobacteria; o__Myxococcales; f__ & 0.871 & 0.0022 & 0.00232 & 0.00008 & 0.00234 & 0.00071 & 0.00000 & 0.00000 & 0.00019 & 0.00000 & 0.00021 \\
\hline Proteobacteria; c_Deltaproteobacteria; o_Myxococcales; f__ & 0.840 & 0.0046 & 0.00017 & 0.00000 & 0.00104 & 0.00000 & 0.00019 & 0.00000 & 0.00000 & 0.00000 & 0.00000 \\
\hline Proteobacteria; c_Deltaproteobacteria; o_Myxococcales; f__ & 0.830 & 0.0056 & 0.00017 & 0.00008 & 0.00043 & 0.00000 & 0.00000 & 0.00000 & 0.00000 & 0.00000 & 0.00000 \\
\hline Proteobacteria; c_Deltaproteobacteria; o_Myxococcales; f__ & 0.812 & 0.0079 & 0.00017 & 0.00000 & 0.00069 & 0.00000 & 0.00010 & 0.00018 & 0.00029 & 0.00000 & 0.00000 \\
\hline Proteobacteria; c_Deltaproteobacteria; o_Myxococcales; f_Haliangiaceae & 0.832 & 0.0054 & 0.00009 & 0.00000 & 0.00035 & 0.00000 & 0.00019 & 0.00000 & 0.00000 & 0.00000 & 0.00000 \\
\hline Proteobacteria; c_Gammaproteobacteria & 0.818 & 0.0071 & 0.00009 & 0.00000 & 0.00017 & 0.00000 & 0.00000 & 0.00000 & 0.00010 & 0.00000 & 0.00000 \\
\hline Proteobacteria; c_Gammaproteobacteria; o_Chromatiales; f_Sinobacteraceae & 0.855 & 0.0033 & 0.00009 & 0.00000 & 0.00009 & 0.00000 & 0.00000 & 0.00000 & 0.00000 & 0.00000 & 0.00000 \\
\hline Proteobacteria; c_Gammaproteobacteria; o_Chromatiales; f_Sinobacteraceae & 0.820 & 0.0067 & 0.00232 & 0.00059 & 0.00260 & 0.00187 & 0.00183 & 0.00136 & 0.00241 & 0.00127 & 0.00113 \\
\hline Proteobacteria; c_Gammaproteobacteria; o_Chromatiales; f_Sinobacteraceae & 0.804 & 0.0089 & 0.00369 & 0.00125 & 0.00390 & 0.00249 & 0.00068 & 0.00164 & 0.00125 & 0.00103 & 0.00165 \\
\hline Proteobacteria; c_Gammaproteobacteria; o_Legionellales; f_Coxiellaceae & 0.885 & 0.0015 & 0.00009 & 0.00000 & 0.00017 & 0.00000 & 0.00000 & 0.00000 & 0.00000 & 0.00000 & 0.00000 \\
\hline Proteobacteria; C_Gammaproteobacteria; o_Xanthomonadales; f_Xanthomonadaceae & 0.874 & 0.0021 & 0.00017 & 0.00000 & 0.00043 & 0.00000 & 0.00000 & 0.00000 & 0.00000 & 0.00000 & 0.00000 \\
\hline Proteobacteria; c_Gammaproteobacteria; 0_Xanthomonadales; f__Xanthomonadaceae & 0.808 & 0.0084 & 0.00043 & 0.00000 & 0.00329 & 0.00009 & 0.00000 & 0.00000 & 0.00000 & 0.00000 & 0.00000 \\
\hline TM6; c_SJA-4; o__; f_ _ _ _ _ n & 0.855 & 0.0033 & 0.00009 & 0.00000 & 0.00009 & 0.00000 & 0.00000 & 0.00000 & 0.00000 & 0.00000 & 0.00000 \\
\hline TM6; C_SJA-4; O_;f__ & -0.824 & 0.0063 & 0.00000 & 0.00033 & 0.00000 & 0.00000 & 0.00000 & 0.00018 & 0.00010 & 0.00032 & 0.00041 \\
\hline TM7; c_TM7-1; o_;f__ & 0.885 & 0.0015 & 0.00009 & 0.00000 & 0.00017 & 0.00000 & 0.00000 & 0.00000 & 0.00000 & 0.00000 & 0.00000 \\
\hline Verrucomicrobia; c_Opitutae; o_Opitutales; f_Opitutaceae & 0.886 & 0.0015 & 0.00043 & 0.00000 & 0.00139 & 0.00000 & 0.00029 & 0.00000 & 0.00000 & 0.00000 & 0.00000 \\
\hline Verrucomicrobia; c_Opitutae; o_Opitutales; f_Opitutaceae & 0.814 & 0.0076 & 0.00034 & 0.00000 & 0.00087 & 0.00053 & 0.00019 & 0.00009 & 0.00000 & 0.00008 & 0.00021 \\
\hline Verrucomicrobia; c_Spartobacteria; o_Spartobacteriales; f_Spartobacteriaceae & 0.887 & 0.0014 & 0.00017 & 0.00000 & 0.00026 & 0.00000 & 0.00000 & 0.00000 & 0.00000 & 0.00000 & 0.00000 \\
\hline Verrucomicrobia; c_Verrucomicrobiae; o_Verrucomicrobiales; f_ & 0.855 & 0.0033 & 0.00009 & 0.00000 & 0.00009 & 0.00000 & 0.00000 & 0.00000 & 0.00000 & 0.00000 & 0.00000 \\
\hline Verrucomicrobia; c_Verrucomicrobiae; o_Verrucomicrobiales; f__ & 0.851 & 0.0036 & 0.00026 & 0.00008 & 0.00130 & 0.00027 & 0.00019 & 0.00000 & 0.00019 & 0.00000 & 0.00010 \\
\hline WPS-2;c_;o_;f_- & 0.949 & 0.0001 & 0.00017 & 0.00000 & 0.00043 & 0.00018 & 0.00010 & 0.00009 & 0.00010 & 0.00000 & 0.00000 \\
\hline
\end{tabular}

a known grouping (undescribed) are indicated by a terminal $\mathrm{c}, \mathrm{O} \ldots$, or $\mathrm{f}$ 


\subsubsection{Supplmementary Table 7.1.7: Bog OTUs with a significant correlation between weighted abundance and the percentage of mercury present as methylmercury $(\% \mathrm{MeHg})$}

Supplementary Table 7 page 1 of 3: Bog OTUs with a significant correlation between weighted abundance and the percentage of mercury present as methylmercury (\%-MeHg)

rcrit $=0.798 \alpha=0.01$

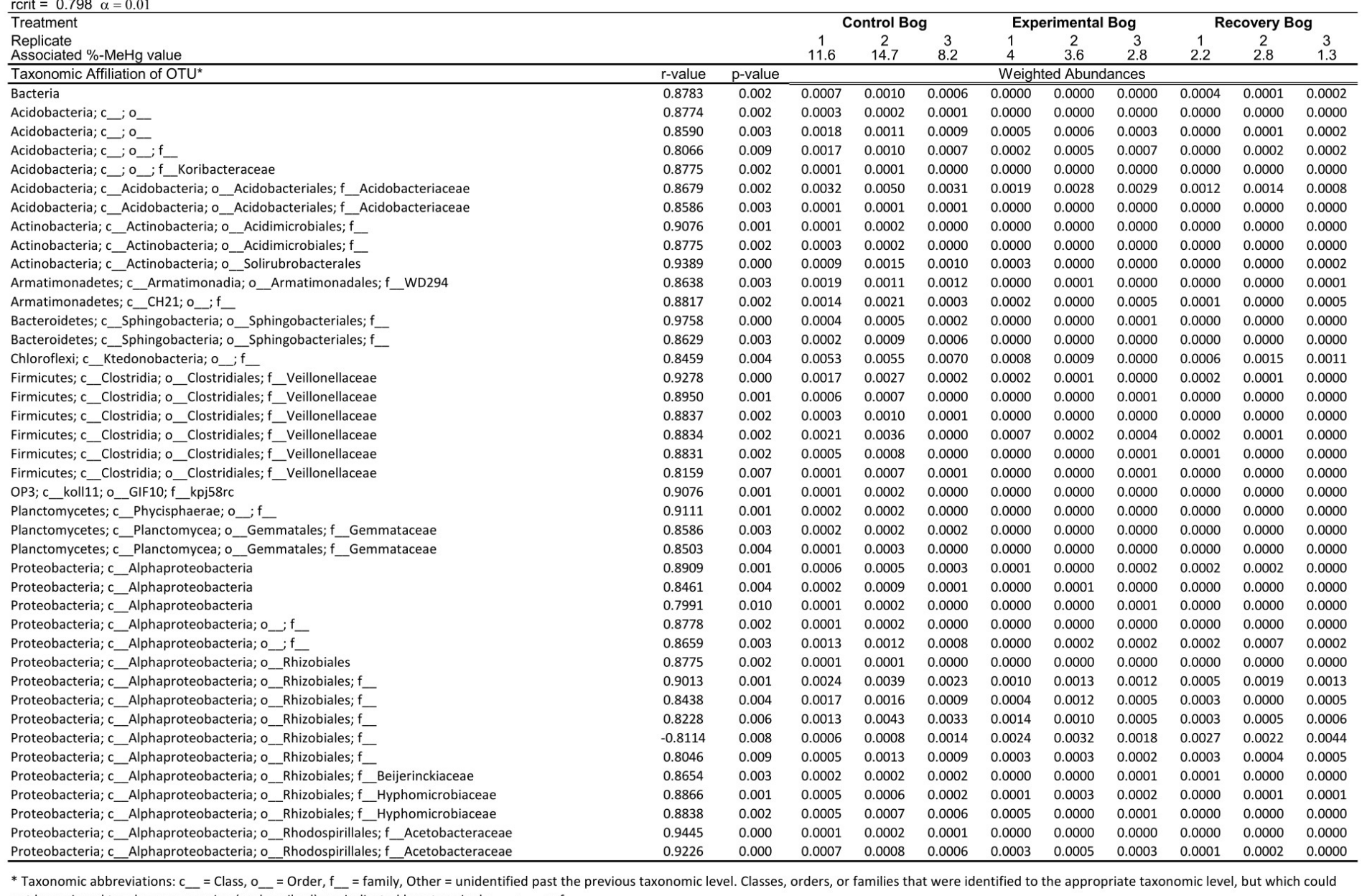

or f previous taxonomic level. Classes, orders, or families that were identified to the appropriate taxonomic level, but which could

not be assigned to a known grouping (undescribed) are indicated by a terminal $c_{\ldots}, 0 \ldots$ or $f$ 
Supplementary Table 7 page 2 of 3: Bog OTUs with a significant correlation between weighted abundance and the percentage of mercury present as methylmercury (\%-MeHg)

\begin{tabular}{|c|c|c|c|c|c|c|c|c|c|c|c|}
\hline \multirow{2}{*}{$\begin{array}{l}\text { Treatment } \\
\text { Replicate } \\
\text { Associated \%-MeHg value }\end{array}$} & & & \multicolumn{3}{|c|}{ Control Bog } & \multicolumn{3}{|c|}{ Experimental Bog } & \multicolumn{3}{|c|}{ Recovery Bog } \\
\hline & & & $\begin{array}{c}1 \\
11.6\end{array}$ & $\begin{array}{c}2 \\
14.7\end{array}$ & $\begin{array}{c}3 \\
8.2\end{array}$ & $\begin{array}{l}1 \\
4\end{array}$ & $\begin{array}{c}2 \\
3.6\end{array}$ & $\begin{array}{c}3 \\
2.8\end{array}$ & $\begin{array}{c}1 \\
2.2\end{array}$ & $\begin{array}{c}2 \\
2.8\end{array}$ & $\begin{array}{c}3 \\
1.3\end{array}$ \\
\hline Taxonomic Affiliation of OTU* & $r$-value & $\mathrm{p}$-value & \multicolumn{9}{|c|}{ Weighted Abundances } \\
\hline Proteobacteria; c_Alphaproteobacteria; o__Rhodospirillales; $f$ _Acetobacteraceae & 0.9089 & 0.001 & 0.0006 & 0.0005 & 0.0001 & 0.0000 & 0.0001 & 0.0001 & 0.0000 & 0.0000 & 0.0000 \\
\hline Proteobacteria; c_Alphaproteobacteria; o__Rhodospirillales; f_Acetobacteraceae & 0.8901 & 0.001 & 0.0028 & 0.0019 & 0.0016 & 0.0001 & 0.0005 & 0.0007 & 0.0003 & 0.0003 & 0.0001 \\
\hline Proteobacteria; c_Alphaproteobacteria; o__Rhodospirillales; f_Acetobacteraceae & 0.8857 & 0.001 & 0.0014 & 0.0011 & 0.0006 & 0.0005 & 0.0003 & 0.0002 & 0.0003 & 0.0006 & 0.0002 \\
\hline Proteobacteria; c_Alphaproteobacteria; o__Rhodospirillales; f_Acetobacteraceae & 0.8839 & 0.002 & 0.0010 & 0.0007 & 0.0002 & 0.0000 & 0.0000 & 0.0000 & 0.0000 & 0.0000 & 0.0001 \\
\hline Proteobacteria; c_Alphaproteobacteria; o__Rhodospirillales; f_Acetobacteraceae & 0.8732 & 0.002 & 0.0005 & 0.0004 & 0.0001 & 0.0000 & 0.0002 & 0.0000 & 0.0000 & 0.0000 & 0.0000 \\
\hline Proteobacteria; c_Alphaproteobacteria; o__Rhodospirillales; f_Acetobacteraceae & 0.8723 & 0.002 & 0.0006 & 0.0003 & 0.0002 & 0.0001 & 0.0001 & 0.0000 & 0.0000 & 0.0000 & 0.0000 \\
\hline Proteobacteria; c_Alphaproteobacteria; o__Rhodospirillales; f_Acetobacteraceae & 0.8468 & 0.004 & 0.0004 & 0.0010 & 0.0002 & 0.0000 & 0.0000 & 0.0000 & 0.0000 & 0.0003 & 0.0002 \\
\hline Proteobacteria; c_Alphaproteobacteria; o__Rhodospirillales; f_Acetobacteraceae & 0.8385 & 0.005 & 0.0003 & 0.0002 & 0.0003 & 0.0001 & 0.0001 & 0.0001 & 0.0000 & 0.0000 & 0.0000 \\
\hline Proteobacteria; c_Alphaproteobacteria; o__Rhodospirillales; f_Acetobacteraceae & 0.8255 & 0.006 & 0.0013 & 0.0011 & 0.0012 & 0.0000 & 0.0000 & 0.0000 & 0.0002 & 0.0000 & 0.0005 \\
\hline Proteobacteria; c_Alphaproteobacteria; o__Rhodospirillales; f_Acetobacteraceae & -0.8189 & 0.007 & 0.0000 & 0.0000 & 0.0000 & 0.0001 & 0.0002 & 0.0002 & 0.0003 & 0.0004 & 0.0004 \\
\hline Proteobacteria; c_Alphaproteobacteria; o__Rhodospirillales; f_Acetobacteraceae & 0.8002 & 0.010 & 0.0014 & 0.0008 & 0.0005 & 0.0000 & 0.0003 & 0.0000 & 0.0000 & 0.0002 & 0.0004 \\
\hline Proteobacteria; c_Alphaproteobacteria; o_Rhodospirillales; $f$ _Rhodospirillaceae & 0.8312 & 0.005 & 0.0002 & 0.0003 & 0.0000 & 0.0001 & 0.0000 & 0.0000 & 0.0000 & 0.0000 & 0.0001 \\
\hline Proteobacteria; c_Betaproteobacteria; o_Burkholderiales & 0.8218 & 0.007 & 0.0061 & 0.0032 & 0.0007 & 0.0000 & 0.0000 & 0.0000 & 0.0000 & 0.0000 & 0.0000 \\
\hline Proteobacteria; c_Betaproteobacteria; o_Gallionellales; f_Gallionellaceae & 0.9607 & 0.000 & 0.0017 & 0.0021 & 0.0015 & 0.0005 & 0.0003 & 0.0000 & 0.0001 & 0.0001 & 0.0004 \\
\hline Proteobacteria; c_Deltaproteobacteria; o__Desulfovibrionales; $f$ _Desulfovibrionaceae & 0.8169 & 0.007 & 0.0008 & 0.0003 & 0.0003 & 0.0000 & 0.0000 & 0.0000 & 0.0000 & 0.0000 & 0.0000 \\
\hline Proteobacteria; c_Deltaproteobacteria; o_Myxococcales; $f$ _ & 0.9445 & 0.000 & 0.0001 & 0.0002 & 0.0001 & 0.0000 & 0.0000 & 0.0000 & 0.0000 & 0.0000 & 0.0000 \\
\hline Proteobacteria; c_Deltaproteobacteria; o__Myxococcales; f_ & 0.8856 & 0.001 & 0.0008 & 0.0007 & 0.0008 & 0.0000 & 0.0002 & 0.0000 & 0.0002 & 0.0000 & 0.0001 \\
\hline Proteobacteria; c_Deltaproteobacteria; o__Syntrophobacterales; $f$ _Syntrophobacteraceae & 0.8879 & 0.001 & 0.0012 & 0.0008 & 0.0005 & 0.0000 & 0.0001 & 0.0000 & 0.0001 & 0.0002 & 0.0002 \\
\hline Proteobacteria; c_Deltaproteobacteria; o_syntrophobacterales; $f$ _Syntrophobacteraceae & 0.8333 & 0.005 & 0.0006 & 0.0009 & 0.0001 & 0.0001 & 0.0000 & 0.0004 & 0.0000 & 0.0000 & 0.0001 \\
\hline Proteobacteria; c_Gammaproteobacteria & 0.9563 & 0.000 & 0.0001 & 0.0002 & 0.0001 & 0.0000 & 0.0000 & 0.0000 & 0.0000 & 0.0000 & 0.0000 \\
\hline Proteobacteria; c_Gammaproteobacteria & 0.9064 & 0.001 & 0.0002 & 0.0004 & 0.0003 & 0.0000 & 0.0000 & 0.0000 & 0.0000 & 0.0000 & 0.0000 \\
\hline Proteobacteria; c_Gammaproteobacteria; o_Chromatiales; f_Sinobacteraceae & 0.8775 & 0.002 & 0.0002 & 0.0002 & 0.0000 & 0.0000 & 0.0000 & 0.0000 & 0.0000 & 0.0000 & 0.0000 \\
\hline Proteobacteria; c_Gammaproteobacteria; o_Chromatiales; f__Sinobacteraceae & 0.8010 & 0.009 & 0.0034 & 0.0016 & 0.0018 & 0.0006 & 0.0009 & 0.0004 & 0.0002 & 0.0006 & 0.0001 \\
\hline Proteobacteria; c_Gammaproteobacteria; o_Legionellales; f_Coxiellaceae & 0.9458 & 0.000 & 0.0009 & 0.0007 & 0.0006 & 0.0000 & 0.0000 & 0.0000 & 0.0000 & 0.0000 & 0.0000 \\
\hline
\end{tabular}

* Taxonomic abbreviations: $c_{\ldots}=$ Class, o_ = Order, $f_{-}=$family, Other = unidentified past the previous taxonomic level. Classes, orders, or families that were identified to the appropriate taxonomic level, but which could not be assigned to a known grouping (undescribed) are indicated by a terminal $\mathrm{c}, \mathrm{O}$, or $\mathrm{f}$ 
Supplementary Table 7 page 3 of 3: Bog OTUs with a significant correlation between weighted abundance and the percentage of mercury present as methylmercury (\%-MeHg)

\begin{tabular}{|c|c|c|c|c|c|c|c|c|c|c|c|}
\hline \multirow{2}{*}{$\begin{array}{l}\text { Treatment } \\
\text { Replicate } \\
\text { Associated \%-MeHg value }\end{array}$} & & & \multicolumn{3}{|c|}{ Control Bog } & \multicolumn{3}{|c|}{ Experimental Bog } & \multicolumn{3}{|c|}{ Recovery Bog } \\
\hline & & & $\begin{array}{c}1 \\
11.6 \\
\end{array}$ & $\begin{array}{c}2 \\
14.7\end{array}$ & $\begin{array}{c}3 \\
8.2 \\
\end{array}$ & $\begin{array}{l}1 \\
4 \\
\end{array}$ & $\begin{array}{c}2 \\
3.6 \\
\end{array}$ & $\begin{array}{c}3 \\
2.8\end{array}$ & $\begin{array}{c}1 \\
2.2 \\
\end{array}$ & $\begin{array}{c}2 \\
2.8 \\
\end{array}$ & $\begin{array}{c}3 \\
1.3 \\
\end{array}$ \\
\hline Taxonomic Affiliation of OTU* & $r$-value & $\mathrm{p}$-value & \multicolumn{9}{|c|}{ Weighted Abundances } \\
\hline TM6; C_SJA-4; o__;f_ & 0.8035 & 0.009 & 0.0003 & 0.0002 & 0.0002 & 0.0000 & 0.0000 & 0.0000 & 0.0001 & 0.0000 & 0.0000 \\
\hline TM7; c_TM7-1; o_;f_ & 0.9111 & 0.001 & 0.0002 & 0.0002 & 0.0000 & 0.0000 & 0.0000 & 0.0000 & 0.0000 & 0.0000 & 0.0000 \\
\hline TM7; c_TM7-1; o_;f_ & 0.8586 & 0.003 & 0.0001 & 0.0001 & 0.0001 & 0.0000 & 0.0000 & 0.0000 & 0.0000 & 0.0000 & 0.0000 \\
\hline TM7; C_TM7-1; o_;f__ & 0.8306 & 0.006 & 0.0005 & 0.0020 & 0.0005 & 0.0000 & 0.0000 & 0.0005 & 0.0001 & 0.0001 & 0.0000 \\
\hline Verrucomicrobia; c_Verrucomicrobiae; o__Verrucomicrobiales; $f$ & 0.8990 & 0.001 & 0.0002 & 0.0003 & 0.0001 & 0.0000 & 0.0001 & 0.0000 & 0.0000 & 0.0000 & 0.0001 \\
\hline Verrucomicrobia; c_Verrucomicrobiae; o_Verrucomicrobiales; f__ & 0.8778 & 0.002 & 0.0001 & 0.0002 & 0.0000 & 0.0000 & 0.0000 & 0.0000 & 0.0000 & 0.0000 & 0.0000 \\
\hline Verrucomicrobia; c_Verrucomicrobiae; o_Verrucomicrobiales; f_ & 0.8586 & 0.003 & 0.0001 & 0.0001 & 0.0001 & 0.0000 & 0.0000 & 0.0000 & 0.0000 & 0.0000 & 0.0000 \\
\hline Verrucomicrobia; c_Verrucomicrobiae; o_Verrucomicrobiales; $f$ _Verrucomicrobia subdivision 3 & 0.8775 & 0.002 & 0.0002 & 0.0002 & 0.0000 & 0.0000 & 0.0000 & 0.0000 & 0.0000 & 0.0000 & 0.0000 \\
\hline WPS-2;c_;o_;f__ & -0.8269 & 0.006 & 0.00 & 0.00 & 0.00 & 0.00 & 0.00 & 0.00 & 0.00 & 0.00 & 0.00 \\
\hline
\end{tabular}

WPS-2; _; ; ; ;

$0.8269-0.006$

$0.00 \quad 0.00 \quad 0.00$

$0.00 \quad 0.00$

* Taxonomic abbreviations: $c_{-}=$Class, $0_{-}=$Order, $f_{-}=$family, Other = unidentified past the previous taxonomic level. Classes, orders, or families that were identified to the appropriate taxonomic level, but which could not be assigned to a known grouping (undescribed) are indicated by a terminal $\mathrm{c}, \mathrm{o} \ldots$, or $\mathrm{f}$ 
7.2 Appendix 2: Additional material for Chapter 5: Accumulation and translocation of methylmercury and inorganic mercury in Oryza sativa: an enriched isotope tracer study 


\subsubsection{Supplementary Table 7.2.1: Results of statistical tests}

Table 7.2.1: Results of statistical tests. Tests are presented in the order in which they appear in the text.

\begin{tabular}{|c|c|c|c|c|}
\hline Comparison & Test & \multicolumn{3}{|c|}{ Results } \\
\hline $\begin{array}{l}\text { Significant difference between ambient/tracer IHg ratios in preplanting soil } \\
\text { (1.24) and the ambient/tracer IHg ratio in vegetated or unvegetated soils at any } \\
\text { growth stage? }\end{array}$ & one-way t-test, mu = 1.24 & $\mathrm{t}$ & DF & $\begin{array}{l}\text { Bonferroni- } \\
\text { corrected } p \text {-value }\end{array}$ \\
\hline \multicolumn{5}{|l|}{ Vegetated soils } \\
\hline Tillering & & -0.30 & 8 & 1.000 \\
\hline Flowering & & -0.95 & 8 & 1.000 \\
\hline Maturity & & -0.63 & 9 & 1.000 \\
\hline \multicolumn{5}{|l|}{ Unvegetated soils } \\
\hline Tillering & & -1.55 & 8 & 0.954 \\
\hline Flowering & & -0.38 & 9 & 1.000 \\
\hline Maturity & & -0.97 & 9 & 1.000 \\
\hline $\begin{array}{l}\text { Significant difference in methylmercury accumulation (as \% } \mathrm{MeHg} \text { ) between } \\
\text { vegetated and unvegetated soils at any growth stage? Tested separately for } \\
\text { tracer and ambient MeHg. }\end{array}$ & $\begin{array}{l}\text { two-way ANOVA with } \\
\text { Tukey HSD post-hoc tests }\end{array}$ & $\mathrm{F}$ & DF & $p$-value \\
\hline Tracer \%MeHg - omnibus & & 5.35 & 5 & $<0.001$ \\
\hline Tillering & & & & 0.999 \\
\hline Flowering & & & & 0.241 \\
\hline Maturity & & & & 0.001 \\
\hline Ambient \%MeHg - omnibus & & 2.80 & 5 & 0.026 \\
\hline Tillering & & & & 1.000 \\
\hline Flowering & & & & 0.292 \\
\hline Maturity & & & & 0.213 \\
\hline
\end{tabular}


Table 7.2.1 Cont.: Results of statistical tests. Tests are presented in the order in which they appear in the text.

\begin{tabular}{|c|c|c|c|c|}
\hline $\begin{array}{l}\text { Significant difference between ambient/tracer } \mathrm{MeHg} \text { ratios in soil and plant } \\
\text { tissues at any growth point? }\end{array}$ & $\begin{array}{l}\text { two-way ANOVA with } \\
\text { Tukey HSD post-hoc tests }\end{array}$ & $\mathrm{F}$ & DF & $p$-value \\
\hline Omnibus & & 7.71 & 5 & $<0.001$ \\
\hline Root:Soil & & & & 0.016 \\
\hline Straw:Soil & & & & $<0.001$ \\
\hline \multicolumn{5}{|l|}{ Flowering } \\
\hline Panicle:Soil & & & & 0.002 \\
\hline \multicolumn{5}{|l|}{ Maturity } \\
\hline Root:Soil & & & & $<0.001$ \\
\hline Straw:Soil & & & & $<0.001$ \\
\hline Panicle:Soil & & & & $<0.001$ \\
\hline Grain:Soil & & & & \\
\hline
\end{tabular}

Significant difference between the MeHg mass of individual plants between tillering and flowering, and between flowering and maturity? All plant tissues were summed for each individual plant, and sums compared; grain was omitted for plants at the maturity stage to account for translocation to developing grain.

one-way ANOVA with Tukey HSD post-hoc tests
F DF p-value

Tested separately for tracer and ambient MeHg.

\begin{tabular}{lr} 
Tracer MeHg - omnibus & 5.43 \\
Tillering vs. flowering & 2 \\
Flowering vs. maturity & 0.011 \\
Ambient MeHg - omnibus & 0.014 \\
Tillering vs. flowering & 13.665 \\
Flowering vs. maturity & $<0.001$ \\
& $<0.053$ \\
\hline
\end{tabular}

Significant difference between ambient/tracer IHg in straw vs. roots, or straw vs. soil?

two-way t-test

t DF p-value

Straw vs. roots
Straw vs. soil

4.20

24

3.49

29

$<0.001$

$<0.001$ 


\subsubsection{Table 7.2.2: Summary statistics for different fractions of ambient and tracer mercury from soils}

Supplementary Table 2: Summary statistics (mean \pm standard deviation) for different fractions of ambient and tracer mercury from soils and plant tissues over the three plant growth stages $(\mathrm{N}=10)$. Ambient and tracer mercury levels in preplanting soils $(\mathrm{N}=3)$ are included for comparison.

\begin{tabular}{|c|c|c|c|c|c|c|c|}
\hline & & $\begin{array}{c}\text { Ambient } \\
\text { MeHg }\end{array}$ & Tracer MeHg & $\begin{array}{l}\text { Ambient } \\
\% \mathrm{MeHg}\end{array}$ & $\begin{array}{l}\text { Tracer } \\
\% \mathrm{MeHg}\end{array}$ & Ambient IHg & Tracer IHg \\
\hline \multicolumn{2}{|c|}{ Preplanting amended soils } & $0.41 \pm 0.04$ & $0.68 \pm 0.03$ & $0.73 \pm 0.23$ & $1.48 \pm 0.45$ & $59.95 \pm 18.91$ & $48.6 \pm 16.27$ \\
\hline \multicolumn{2}{|c|}{ Preplanting unamended soils } & $0.45 \pm 0.06$ & & $0.87 \pm 0.11$ & & $50.54 \pm 1.29$ & \\
\hline \multirow{4}{*}{ 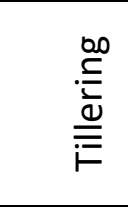 } & Unvegetated Soils & $0.57 \pm 0.03$ & $1.54 \pm 0.2$ & $1.12 \pm 0.07$ & $3.51 \pm 0.4$ & $50.21 \pm 1.75$ & $42.21 \pm 3$ \\
\hline & Vegetated Soils & $0.55 \pm 0.04$ & $1.55 \pm 0.21$ & $1.1 \pm 0.09$ & $3.66 \pm 0.25$ & $49.51 \pm 3.19$ & $40.68 \pm 4.16$ \\
\hline & Roots & $2.93 \pm 0.74$ & $10.89 \pm 1.92$ & $5.75 \pm 1.54$ & $19.81 \pm 5.61$ & $49.96 \pm 12.48$ & $47.89 \pm 17.78$ \\
\hline & Straw & $0.45 \pm 0.14$ & $1.91 \pm 0.66$ & $14.02 \pm 5.01$ & $85.57 \pm 14.58$ & $2.79 \pm 0.55$ & $0.38 \pm 0.55$ \\
\hline \multirow{5}{*}{$\begin{array}{l}\stackrel{\infty}{\subseteq} \\
\frac{5}{d} \\
\frac{2}{3} \\
\frac{0}{4}\end{array}$} & Unvegetated Soils & $0.6 \pm 0.09$ & $1.57 \pm 0.23$ & $1.34 \pm 0.5$ & $4.08 \pm 1.2$ & $46.29 \pm 6.64$ & $38.54 \pm 8.07$ \\
\hline & Vegetated Soils & $0.51 \pm 0.05$ & $1.41 \pm 0.26$ & $1 \pm 0.1$ & $3.17 \pm 0.33$ & $50.72 \pm 2.34$ & $43.03 \pm 4.77$ \\
\hline & Roots & $2.02 \pm 0.55$ & $7.86 \pm 2.62$ & $4.73 \pm 1.27$ & $14.63 \pm 3.2$ & $42.04 \pm 10.99$ & $47.05 \pm 16.65$ \\
\hline & Straw & $0.15 \pm 0.17$ & $0.6 \pm 0.26$ & $3.86 \pm 1.72$ & $80.65 \pm 18.69$ & $3.81 \pm 0.99$ & $0.17 \pm 0.2$ \\
\hline & Panicles & $0.18 \pm 0.07$ & $0.72 \pm 0.35$ & $28.98 \pm 9.96$ & $88.08 \pm 23.16$ & $0.48 \pm 0.22$ & $0.16 \pm 0.37$ \\
\hline \multirow{6}{*}{ 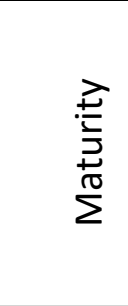 } & Unvegetated Soils & $0.6 \pm 0.07$ & $1.71 \pm 0.25$ & $1.52 \pm 0.57$ & $4.88 \pm 1.6$ & $42.3 \pm 10.31$ & $35.7 \pm 9.15$ \\
\hline & Vegetated Soils & $0.55 \pm 0.13$ & $1.27 \pm 0.22$ & $1.16 \pm 0.31$ & $3.12 \pm 0.43$ & $47.36 \pm 2.18$ & $39.92 \pm 6.16$ \\
\hline & Roots & $1.87 \pm 0.49$ & $6.2 \pm 1.43$ & $5 \pm 0.89$ & $14.03 \pm 1.88$ & $35.49 \pm 5.8$ & $38.07 \pm 7.16$ \\
\hline & Straw & $0.08 \pm 0.05$ & $0.29 \pm 0.13$ & $1.65 \pm 1.14$ & $62.29 \pm 16.75$ & $4.6 \pm 1.2$ & $0.27 \pm 0.39$ \\
\hline & Panicles & $0.13 \pm 0.03$ & $0.44 \pm 0.11$ & $7.31 \pm 1.23$ & $86.03 \pm 7.88$ & $1.69 \pm 0.18$ & $0.07 \pm 0.05$ \\
\hline & Grain & $0.21 \pm 0.07$ & $0.63 \pm 0.21$ & $41.57 \pm 11.9$ & $95.87 \pm 10.25$ & $0.3 \pm 0.08$ & $0.02 \pm 0.06$ \\
\hline
\end{tabular}


Supplementary Table 2 Cont.: Summary statistics (mean \pm standard deviation) for different fractions of ambient and tracer mercury from soils and plant tissues over the three plant growth stages $(\mathrm{N}=10)$. Ambient and tracer mercury levels in preplanting soils $(\mathrm{N}=3)$ are included for comparison.

\begin{tabular}{|c|c|c|c|c|c|c|c|}
\hline & & $\begin{array}{c}\text { Ambient/Tracer } \\
\text { MeHg Ratio }\end{array}$ & $\begin{array}{c}\text { Ambient/Tracer } \\
\text { IHg Ratio }\end{array}$ & $\begin{array}{l}\text { Ambient } \\
\text { MeHg mass } \\
\text { (ng plant }^{-1} \text { ) }\end{array}$ & $\begin{array}{c}\text { Tracer MeHg } \\
\text { mass } \\
\text { (ng plant }^{-1} \text { ) }\end{array}$ & $\begin{array}{c}\text { Ambient IHg } \\
\text { mass } \\
\text { (ng plant }^{-1} \text { ) }\end{array}$ & $\begin{array}{c}\text { Tracer IHg } \\
\text { mass } \\
\text { (ng plant }^{-1} \text { ) }\end{array}$ \\
\hline \multicolumn{2}{|c|}{$\begin{array}{l}\text { Preplanting amended soils } \\
\text { Preplanting unamended soils }\end{array}$} & $0.6 \pm 0.04$ & $1.24 \pm 0.05$ & & & & \\
\hline \multirow{4}{*}{ 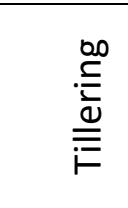 } & Unvegetated Soils & $0.37 \pm 0.04$ & $1.2 \pm 0.08$ & & & & \\
\hline & Vegetated Soils & $0.36 \pm 0.04$ & $1.23 \pm 0.13$ & & & & \\
\hline & Roots & $0.27 \pm 0.02$ & $1.1 \pm 0.27$ & $2.95 \pm 1.01$ & $11 \pm 3.37$ & $54.23 \pm 3.37$ & $52.48 \pm 3.37$ \\
\hline & Straw & $0.23 \pm 0.02$ & $16.76 \pm 19.91$ & $2.02 \pm 1.13$ & $8.4 \pm 4.38$ & $12.29 \pm 4.38$ & $1.41 \pm 4.38$ \\
\hline \multirow{5}{*}{ 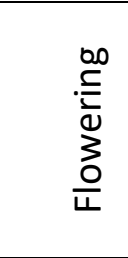 } & Unvegetated Soils & $0.38 \pm 0.04$ & $1.22 \pm 0.16$ & & & & \\
\hline & Vegetated Soils & $0.37 \pm 0.04$ & $1.19 \pm 0.15$ & & & & \\
\hline & Roots & $0.26 \pm 0.04$ & $0.94 \pm 0.23$ & $4.47 \pm 3.47$ & $16.81 \pm 11.44$ & $95.01 \pm 11.44$ & $104.99 \pm 11.44$ \\
\hline & Straw & $0.25 \pm 0.04$ & $64.84 \pm 71.7$ & $3.49 \pm 1.6$ & $14.09 \pm 6$ & $90.43 \pm 6$ & $3.49 \pm 6$ \\
\hline & Panicles & $0.26 \pm 0.04$ & $13.38 \pm 21.11$ & $0.35 \pm 0.1$ & $1.38 \pm 0.45$ & $0.97 \pm 0.45$ & $0.33 \pm 0.45$ \\
\hline \multirow{6}{*}{ 﨎 } & Unvegetated Soils & $0.36 \pm 0.06$ & $1.2 \pm 0.14$ & & & & \\
\hline & Vegetated Soils & $0.44 \pm 0.09$ & $1.21 \pm 0.16$ & & & & \\
\hline & Roots & $0.3 \pm 0.02$ & $0.94 \pm 0.09$ & $3.48 \pm 1.2$ & $11.55 \pm 3.65$ & $181.94 \pm 3.65$ & $193.79 \pm 3.65$ \\
\hline & Straw & $0.23 \pm 0.07$ & $35.53 \pm 19.84$ & $2.01 \pm 1.14$ & $8.16 \pm 2.38$ & $140.57 \pm 2.38$ & $7 \pm 2.38$ \\
\hline & Panicles & $0.31 \pm 0.02$ & $29.46 \pm 22.93$ & $0.67 \pm 0.14$ & $2.18 \pm 0.5$ & $8.61 \pm 0.5$ & $0.36 \pm 0.5$ \\
\hline & Grain & $0.34 \pm 0.05$ & $5.25 \pm 4.36$ & $0.46 \pm 0.18$ & $1.38 \pm 0.63$ & $0.65 \pm 0.63$ & $0.04 \pm 0.63$ \\
\hline
\end{tabular}




\subsubsection{Supplementary Text 1: Estimation of potential gaseous $\mathrm{Hg}$ flux from experimental pots}

$\mathrm{Hg}_{\mathrm{g}}=(\mathrm{A} * \mathrm{e}) /\left(\mathrm{V}_{\mathrm{g}} * \mathrm{~T}_{\mathrm{g}}\right)$

$\mathrm{Hg}_{\mathrm{g}}=$ gaseous $\mathrm{Hg}$ in the atmosphere of the greenhouse which could be derived from the experimental pots $\left(\mathrm{ng} \mathrm{m}^{-2}\right)$

$\mathrm{V}_{\mathrm{g}}=$ greenhouse volume $\left(\mathrm{m}^{3}\right)$

$\mathrm{T}_{\mathrm{g}}=$ air turnovers per hour $\left(\mathrm{h}^{-1}\right)$

A = area of wet soil surface $\left(\mathrm{m}^{2}\right)$

$\mathrm{e}=$ estimated evasion of gaseous $\mathrm{Hg}$ from vegetated wetlands $\left(\mathrm{ng} \mathrm{m}^{-2} \mathrm{~h}^{-1}\right)$

Area of wet soil surface was calculated on the basis of the surface area of both vegetated and unvegetated pots. Evasion of gaseous $\mathrm{Hg}$ from this surface, consisting of vegetated and unvegetated submerged soil, as well as transpirational efflux of gaseous $\mathrm{Hg}$ from the rice plants themselves, was estimated using the findings of Lindberg et al. (2002), who observed a mean daytime flux of approximately $40 \mathrm{ng} \mathrm{m}^{-2} \mathrm{~h}^{-1}$ gaseous elemental mercury over stands of cattails and sawgrass in the Florida Everglades. This value was based on plants that were larger and growing in hotter conditions than our experimental rice, and is thus likely an overestimate for our system. We have also assumed continuous daytime levels of flux, despite the finding that during the night, vegetated wetlands are a net sink of gaseous elemental mercury (Marsik et al., 2005).

Greenhouse air volume was determined based on measurements of the inside of the structure; air turnover rate was not measurable, as the ventilation was passive rather than active. Agriculture Canada guidelines stipulate that greenhouse air turnover, however achieved, should be between 30 and 60 complete replacements per hour (Towning and Turkewitsch, 1980). For our calculations, we used the more conservative value of 30 complete replacements per hour.

$$
\begin{aligned}
& \mathrm{Hg}_{\mathrm{g}}=\left(1.45 \mathrm{~m}^{2} * 40 \mathrm{ng} \mathrm{m}^{-2} \mathrm{~h}^{-1}\right) /\left(249 \mathrm{~m}^{3} * 40 \mathrm{~h}^{-1}\right) \\
& \mathrm{Hg}_{\mathrm{g}}=0.00557 \mathrm{ng} \mathrm{m}^{-3}
\end{aligned}
$$


This represents, at the most, $0.597-0.456 \%$ of the lower and upper bounds of the estimates of gaseous elemental mercury present in the Northern Hemisphere (1.3-1.7 $\mathrm{ng} \mathrm{m}^{-3}$ ) (Driscoll et al. 2013).

\section{References:}

Driscoll, C.T., Mason, R.P., Chan, H.M., Jacob, D.J., Pirrone, N., 2013. Mercury as a global pollutant: sources, pathways, and effects. Environ. Sci. Technol. 47, 4967-4983. http://dx.doi:10.1021/es305071v

Lindberg, S.E., Dong, W., Meyers, T., 2002. Transpiration of gaseous elemental mercury through vegetation in a subtropical wetland in Florida. Atmos. Environ. 36, 5207-5219.

Marsik, F.J., Keeler, G.J., Lindberg, S.E, Zhang, H., 2005. Air-surface exchange of gaseous mercury over a mixed sawgrass -cattail stand within the Florida Everglades. Environ. Sci. Technol. 39, 4739-46. http://dx.doi:10.1021/es0404015.

Towning, D.J., Turkewitsch, A., 1980. Energy efficient greenhouse design and operation. Final report of ERDAF contract 07SZ.01843-0-1908, Agriculture Canada, Ottawa, Canada, $217 \mathrm{pp}$.

\subsubsection{Supplementary Text 2: Estimation of mass balance of MeHg in vegetated pots}

The mass of $\mathrm{MeHg}$ in soil in vegetated pots was compared to the mass of $\mathrm{MeHg}$ in plant tissues. Pots were filled with soil volumetrically $(1.5 \mathrm{~L})$. Using a conservative estimation of a soil volume per pot of $1.25 \mathrm{~L}$, and the average bulk density of the soil as assessed prior to $\mathrm{Hg}$ amendment $\left(0.355 \mathrm{~g} \mathrm{~cm}^{-1}\right)$, the dry mass of soil in each pot was estimated at $485 \mathrm{~g}$. The average mass of MeHg present in vegetated pots was then calculated by multiplying this value by the average concentration of ambient or tracer $\mathrm{MeHg}\left(\mathrm{ng} \mathrm{g}^{-1}\right)$. Results ranged from 247 to $746 \mathrm{ng}$, and are presented in Table 7.2.5. In comparison, the $\mathrm{MeHg}$ mass held in plant tissues was much lower (4 to $33 \mathrm{ng} \mathrm{plant}^{-1}$ ) and represented only 2-5\% of the total MeHg mass in soil. In contrast, the average differences in $\% \mathrm{MeHg}$ between vegetated and unvegetated soils at the flowering and maturity stages ranged from approximately 30-125\% (Table 7.2.2). We therefore conclude that uptake into plant tissues was not a significant route of loss of $\mathrm{MeHg}$ from vegetated soils, and that other unmeasured mechanisms, such as effects on methylation and/or demethylation rates, must explain the difference between net $\mathrm{MeHg}$ accumulation in vegetated and unvegetated soils. 


\subsubsection{Table 7.2.3: Estimated MeHg burden in vegetated sediments at each growth stage}

Table 7.2.3: Estimated MeHg burden in vegetated sediments (ng pot ${ }^{-1}$ ) and plants (ng plant ${ }^{-1}$ ) at each growth stage

\begin{tabular}{lcccccc}
\hline \hline & & & & & \multicolumn{2}{c}{$\begin{array}{c}\text { Percent soil mass } \\
\text { translocated to plant } \\
\text { tissue }\end{array}$} \\
\cline { 2 - 7 } & Tracer & Ambient & Tracer & Ambient & Tracer & Ambient \\
Tillering & 747 & 267 & 17 & 4 & 2 & 2 \\
Flowering & 684 & 247 & 33 & 8 & 5 & 3 \\
Maturity & 616 & 267 & 22 & 6 & 3 & 2 \\
\end{tabular}

7.2.6 Table 7.2.4: Photosynthetic rate and total plant biomass at each growth stage.

Table 7.2.4: Photosynthetic rate and total plant biomass at each growth stage.

\begin{tabular}{ccc}
\hline \hline Growth stage & $\begin{array}{c}\text { Photosynthetic rate } \\
\left(\mu \mathrm{mol} \mathrm{CO}_{2} \mathrm{~m}^{-2} \mathrm{~s}^{-1}\right)\end{array}$ & Total plant dry biomass $(\mathrm{g})$ \\
\hline \hline Preplanting & $9.9 \pm 3.0$ & $5.08 \pm 2.53$ \\
Tillering & $21.2 \pm 5.4$ & $25.61 \pm 10.53$ \\
Flowering & $12.2 \pm 1.6$ & $41.57 \pm 8.73$ \\
Grain maturity & $7.8 \pm 1.7$ & \\
\hline \hline
\end{tabular}

